\title{
BIGANOS EM PORTUGAL, ESPANHA E BRASIL analisando contextos, demandas e processos identitários
}





\section{CIGANOS EM PORTUGAL, ESPANHA E BRASIL:}

ANALISANDO CONTEXTOS, DEMANDAS E PROCESSOS IDENTITÁRIOS

2020

Organização

Olga Magano

Maria Manuela Mendes

cies_iscte iscte

instruro

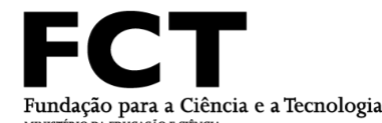


CIGANOS EM PORTUGAL, ESPANHA E BRASIL: ANALISANDO CONTEXTOS, DEMANDAS E PROCESSOS IDENTITÁRIOS

Olga Magano e Maria Manuela Mendes (orgs.)

Novembro, 2020

ISBN: 978-972-8048-52-5

DOI: $10.15847 /$ CIES2020CIGANOSPTESBR

Composição em caracteres Oswald e Times New Roman

Conceção gráfica e composição: Sofia Rocha

Os dados e as opiniões que se encontram na presente publicação são da excluvisa responsabilidade dos/as autores/as.

() Olga Magano e Maria Manuela Mendes (orgs.)

Este trabalho está licenciado com uma Licença Creative Commons

Atribuição-NãoComercial-SemDerivações 4.0 Internacional.

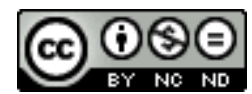




\section{ÍNDICE}

$\begin{array}{ll}\text { Índice de figuras } & 7\end{array}$

$\begin{array}{lr}\text { Índice de tabelas } & 8\end{array}$

$\begin{array}{ll}\text { Índice de gráficos } & 9\end{array}$

$\begin{array}{ll}\text { Nota de apresentação } & 11\end{array}$

\section{PARTE I DESAFIOS METODOLÓGICOS NA PESQUISA SOBRE CIGANOS}

1. Investigação sobre pessoas ciganas em Portugal. Hiato entre conhecimento e desenho de políticas públicas

Olga Magano

Maria Manuela Mendes

2. Considerações metodológicas acerca de estudos quantitativos sobre pessoas ciganas. Três questões e problemas associados às suas respostas

Pedro Candeias

3. Desafios Metodológicos na pesquisa sobre ciganos: cenários, desenhos de pesquisa e questões metodológicas no contexto brasileiro

Igor Shimura

4. Será possível a decolonização dos Estudos Ciganos? Um ensaio sobre a relação ciganos e ciência

Aluízio de Azevedo Silva

\section{PARTE II CIGANOS, PERCURSOS ESCOLARES E LITERACIA}

5. Imaginarios divergentes, caminos convergentes. La importancia de una nueva didáctica de las ciencias sociales en un contexto educativo con vulnerabilidad social de la ciudad de Huelva (España). Una aproximación antropológica

Juan Carlos Romero Villadóniga

6. Literacia digital das pessoas ciganas de Reguengos de Monsaraz

Carlos Medinas

Olga Magano 
7. Perceções dos estudantes ciganos e dos técnicos dos projetos Escolhas sobre as trajetórias escolares de continuidade ao nível do ensino secundário

Bruno Baptista

Maria Manuela Mendes

\section{PARTE III CONTEXTOS, ATIVISMO CIGANO E MOBILIZAÇÕES DE EMANCIPAÇÃO}

8. Ciganos/as no Brasil: ações, mobilizações e ativismo político

Jamilly Rodrigues da Cunha

9. Contextos e participação social

Elisa Costa

10. Desafios e conquistas à visibilidade do povo romani nas políticas sociais brasileiras

Lucimara Cavalcante

\section{PARTE IV CIGANOS, CASAMENTO E ENVELHECIMENTO}

11. La expansión de los matrimonios mixtos entre los Gitanos/Calé de España. Análisis de un caso

Juan F. Gamella

12. Principales resultados del estudio: La experiencia gitana de la vejez. Estudio psicoantropológico de las diferencias culturales en los procesos de envejecimiento y sus consecuencias psicosociales.

Ángel Heredia Amador

Juan Francisco Gamella Mora

Jose María Salinas Martínez de Lecea 


\section{Índice de figuras}

Estimativas para o número de Ciganos em Portugal e taxa de resposta

Modelo heurístico de integração de Penninx

Ubicación de la barriada Diego Sayago en el contexto de la ciudad de Huelva.

Fuente: Google Maps.

Análisis de una situación de conflicto y subsistemas que operarán en él. Fuente:

Romero-Villadóniga, 2019.

Evolución de los matrimonios mixtos en la población gitana/calé de 22 municipios contiguos en Andalucía oriental. Porcentajes de matrimonios mixtos sobre el total de matrimonios gitanos 


\section{Índice de tabelas}

Caraterísticas de estudos sociodemográficos sobre Ciganos

Opiniões, atitudes e práticas dos portugueses em relação a Ciganos

Matrimonios mixtos en la población gitana de 22 municipios contiguos de la provincia de Granada, España (1900 a 2006)

Distribución de la muestra por grupos de edad, sexo-género y etnia

Porcentajes de respuestas afirmativas de gitanos y no gitanos, a los ítems de la escala de actitutes ante el envejecimiento, calculados según el propio grupo étnico. 


\section{Índice de gráficos}

Evolução de Ciganos matriculados em escolas de Reguengos de Monsaraz

Frequência de utilização da Internet

Expressões conhecidas sobre uso de Internet

Finalidades de uso de Internet

Utilização dos Média

123

Efectos sobre la etnia y el sexo sobre las puntuaciones del cuestionario 



\section{Nota de apresentação}

Nos dias 3 e 4 de junho 2019 realizou-se o Seminário Internacional Ciganos em Portugal, Espanha e Brasil: analisando contextos, demandas e processos identitátios no Iscte-Instituto Universitário de Lisboa. A organização do seminário esteve a cargo de Olga Magano (Professora Auxiliar Universidade Aberta e investigadora do CIES-Iscte / Iscte), Maria Manuela Mendes (Professora da Faculdade de Arquitetura da Universidade de Lisboa e investigadora do CIESIscte/ Iscte), Jamilly Cunha e Renato Athias (Universidade Federal de Pernambuco - Brasil). Este evento só foi possível com o apoio da Fundo de Apoio à Comunidade Científica (FACC) da Fundação para a Ciência e Tecnologia (FCT), da Associação Portuguesa de Sociologia e do Centro de Investigação e Estudos em Sociologia do Instituto Universitário de Lisboa (CIESIscte).

O seminário foi constituído por várias sessões em que participaram investigadores, mediadores, ativistas ciganos e decisores políticos em torno da discussão de 5 eixos temáticos: Avanços e Impasses: investigar sobre e com Ciganos; Desafios metodológicos na pesquisa sobre Ciganos, Cenários, desenhos de pesquisa e questões metodológicas; Políticas Sociais e impactos; Contextos, Participação e mediação; Contextos, Acção Política e associativa. O objetivo passou por estabelecer um espaço de diálogo e de circulação de saberes e práticas entre investigadores, mediadores e associativistas dos três países: Portugal, Espanha e Brasil, tendo-se discutido entre outras questões, as pesquisas mais recentes e as metodologias seguidas, as dificuldades nos processos de mediação;questões de cultura, racismo, integração, exclusão e discriminação e formas de envolvimento de pessoas ciganas nos processos investigativos.

Foi um seminário extremamente enriquecedor e inovador por ter permitido a partilha de experiências e conhecimentos relativas à situação social mais recente e que marca o quadro de vida dos Ciganos em Portugal, Espanha e no Brasil, em 3 países que estão profundamente interligados por razões históricas, geográficas, sociais, culturais, económicas, políticas e que apresentam mais similaridades do que distintividades face à situação em análise. Para além dos contributos de resultados de projetos de investigação contou-se com a partilha de experiências profissionais de pessoas ciganas, de mediadores e ativistas.

Desse seminário resultou o e-book que agora se publica, com textos de alguns dos participantes. O ebook está organizado em 4 partes: na primeira parte é feita uma abordagem sobre desafios metodológicos na investigação sobre ciganos e no hiato que existe entre a teoria e a investigação empírica, na segunda parte são apresentadados alguns contributos que nos ajudam 
a conhecer questões relacionadas com percursos escolares e literacia, na terceira parte são referenciadas dimensões sobre a fomentação do ativismo cigano e mobilizações de emancipação. Por fim, na quarta parte são trazidos dois contributos sobre as dinâmicas de casamento e também uma reflexão sobre o envelhecimento. Com esta publicação pretende-se inaugurar um espaço de debate internacional de investigação científica e de intervenção social e política sobre as temáticas aqui em análise.

A edição deste e-book só é possível devido ao apoio institucional do CIES-Iscte, Iscte-Instituto Universitário de Lisboa e de todos os autores e todas as autoras que gentilmente partilham o seu conhecimento com o público em geral.

Esperemos que a diversidade e a atualidade dos temas abordados suscitem uma leitura estimulante e profícua! 


\section{PARTE I \\ DESAFIOS METODOLÓGICOS NA PESQUISA SOBRE CIGANOS}




\title{
Capítulo 1. \\ Investigação sobre pessoas ciganas em Portugal. Hiato entre conhecimento e desenho de políticas públicas
}

\author{
OLGA MAGANO ${ }^{1}$ \\ Universidade Aberta \\ Iscte - Instituto Universitário de Lisboa, Centro de Investigação e Estudos de Sociologia (CIES-Iscte) \\ olgamagano@gmail.com
}

MARIA MANUEla MENDES ${ }^{2}$

Iscte - Instituto Universitário de Lisboa, Centro de Investigação e Estudos de Sociologia (CIES-Iscte)

FAUL, Universidade de Lisboa, Lisboa, Portugal

mamendesster@gmail.com

Resumo: O objetivo deste artigo é fazer uma reflexão exploratória sobre os Ciganos enquanto construção social e os percursos teórico-metodológicos prosseguidos em Portugal. A construção social da imagem sobre os Ciganos em Portugal é imputada, a maior parte das vezes, a aspetos negativos quanto a modos de vida marginais (muitas vezes vistos como "parasitas"

\footnotetext{
${ }^{1}$ Olga Magano é professora na Universidade Aberta e investigadora do Centro de Estudos e Investigação em Sociologia (CIES), do Instituto Universitário de Lisboa, Iscte. É Licenciada em Sociologia pela Faculdade de Letras da Universidade do Porto, Mestre em Relações Interculturais e Doutorada em Sociologia pela Universidade Aberta. Já participou e co-coordenou alguns projetos sobre os ciganos em Portugal e atualmente co-coordena o projeto de investigação EDUCIG - Desempenhos educacionais entre os ciganos: projeto de investigação-ação e de codesign" (referência PTDC/CED-EDG/30175/2017). É co-coordenadora da Secção Temática Diversidades Culturais e Intervenção Social, da Associação Portuguesa de Sociologia, é membro da Gypsy Lore Society, da European Academic Network on Romani Studies e da Associação Internacional de Ciências Sociais e Humanas de Língua Portuguesa. É também membro da equipa do Observatório dos Percursos Profissionais e de vida dos Diplomados da Universidade Aberta.

${ }^{2}$ Maria Manuela Mendes é professora na Faculdade de Arquitetura da Universidade de Lisboa (FAUL) e Doutora em Ciências Sociais pelo Instituto de Ciências Sociais da UL. É investigadora integrada no Centro de Estudos e Investigação em Sociologia do Instituto Universitário de Lisboa (CIES-Iscte) desde 2008; é ainda membro colaborado do Centro de Arquitetura de Pesquisa, Urbanismo e Design (CIAUD-FAUL) e do Instituto de Sociologia Faculdade de Letras do Porto (ISFLUP). As principais áreas de investigação estão focadas em algumas temáticas, como grupos étnicos, racismo, estudos ciganos, imigração, cidade e diversidade, exclusão social e espacial, habitação e políticas de habitação, processos de realojamento, entre outras. Já participou e co-coordenou alguns projetos sobre os ciganos em Portugal e Espanha e atualmente co-coordena o projeto de investigação EDUCIG - Desempenhos educacionais entre os ciganos: projeto de investigação-ação e de codesign" (referência PTDC/CEDEDG/30175/2017).
} 
sociais) e a um suposto desinteresse de integração na sociedade portuguesa, aspetos que condicionam os olhares etnocêntricos sobre a pessoas Ciganas e também o modo como pesquisadores problematizam e investigam.

Nos últimos anos têm aumentado de forma significativa os trabalhos desenvolvidos sobre os Ciganos em Portugal o que nos tem permitido conhecer pesquisas realizadas nas várias Ciências Sociais, sobretudo em Sociologia e Antropologia em que se tenta romper com estigmas e dar a conhecer a realidade plural e não homogénea da cultura e das pessoas Ciganas. Pretendemos deixar aqui algumas pistas para sistematização e exploração sobre este percurso da construção do conhecimento sobre os Ciganos em Portugal e a sua não incorporação no desenho de políticas públicas.

Palavras-Chave: Ciganos; Portugal; Investigação científica

\begin{abstract}
The aim of this article is to make an exploratory approach on Ciganos as a social construction and the theoretical and methodological paths followed in Portugal. The social construction of the image about Ciganos in Portugal is mostly attributed to negative aspects regarding marginal ways of life (often seen as social "parasites") and a supposed lack of interest in integration in Portuguese society, aspects that condition ethnocentric views on Roma people and also the way researchers problematize and investigate.

In recent years, there has been a significant increase in the work developed on Gypsies in Portugal, which has enabled us to learn about research carried out in the various Social Sciences, especially in Sociology and Anthropology, in which we try to break with stigmas and make known the plural reality and not homogeneous culture of Roma/ Ciganos. We intend to leave here some clues for systematization and exploration on this path of building knowledge about Ciganos in Portugal and their non-incorporation in the design of public policies.
\end{abstract}

Keywords: Roma; Ciganos; Portugal; Scientific Research

\title{
Nota introdutória
}

O objetivo deste artigo é traçar uma breve panorâmica sobre as investigações que tomam os Ciganos como objeto de estudo em Portugal numa análise que aborda desde as primeiras incursões investigativas até a estudos desenvolvidos dentro e fora da academia, com vista a denunciar a situação de pobreza, exclusão social, racismo, segregação social, insucesso e abandono escolar, dificuldades de acesso à habitação, à saúde, ao mercado de trabalho e a rendimentos constantes, mas também a interações sociais entre ciganos e não ciganos e a formas de integração social, por vezes, desconhecidas do público em geral. 
Apresenta-se uma análise diacrónica e sincrónica dos estudos sobre ciganos em Portugal assim como se salienta a importância dos resultados produzidos para a elaboração de recomendações de intervenção social e para desenho de políticas públicas.

\section{Os Ciganos como objeto de estudo}

Em Portugal, a referência a pessoas Ciganas data desde o princípio do século XVI. Aparecem referenciados em 1516 no Cancioneiro Geral de Garcia de Resende (Mendes, 2007) e no teatro e literatura, como a "Farsa dos Ciganos" (1521), de Gil Vicente mas também em termos legislativos sobretudo no sentido de reprimir comportamentos e práticas identificativas do grupo cigano e impedir deambulações por território nacional. É possível encontrar registos de perseguições legislativas, condenações a galés e ao degredo e expulsões do território (Costa, 1995 e 1996; Alfaro, Costa \& Floate, 1999; Mendes, 1997 e 2007; Bastos, Correia \& Rodrigues, 2007).

Embora seja de ressalvar as análises etnográficas de Leite Vasconcelos (1958), Teófilo Braga (1879) e Rocha Peixoto ([1897] 1967), os dois primeiros estudos de maior densidade e profundidade dedicados exclusivamente aos Ciganos são os de Adolfo Coelho, em 1892, com a publicação: Os ciganos de Portugal: com um estudo sobre o calão e o de Olímpio Nunes da década de 70, do século XX, intitulado O Povo Cigano, constituindo uma obra de maior fôlego. O primeiro, a partir do estudo da língua aborda alguns aspetos da cultura cigana e o segundo, faz uma incursão pelos ciganos em várias localidades do país e visa contemplar aspetos culturais como a família, os papéis da mulher e do homem, o casamento, as atividades, o luto, etc.

Durante a década de 90, do século XX, começam a surgir alguns estudos académicos substanciados na forma de dissertações de mestrado em várias áreas das Ciências Sociais, como o caso de Mendes, 1995; Castro, 1995; Pinto, 1995; Magano, 1999, entre outros.

Em termos de apoio à investigação, o ACIME - Alto Comissariado para a Imigração e Minorias Étnicas (posteriormente ACIDI - Alto Comissariado para a Integração e Diálogo Intercultural e atualmente ACM - Alto Comissariado para as Migrações), no final do século XX financia, em parceria com a Fundação para a Ciência e Tecnologia, uma série de estudos sobre ciganos em Portugal e cujas publicações dos projetos apoiados, se encontram disponíveis no âmbito da coleção Olhares do ACM (p.e. Silva, 2005; Cortesão et al, 2005; Dias et al., 2006 e Fonseca et al., 2005), posteriormente foi constituído o OBCIG - Observatório das Comunidades Ciganas, em 2014, registando-se algumas publicações, como o Estudo Nacional sobre as Comunidades Ciganas (Mendes, Magano \& Candeias, 2014) e publicações de teses de doutoramento e de dissertações de mestrado. 
No plano institucional, várias entidades com práticas de intervenção no terreno e de matriz católica, como o Secretariado Diocesano de Lisboa da Obra Nacional da Pastoral dos Ciganos e a Santa Casa da Misericórdia de Lisboa apoiaram a formação de pessoas ciganas e patrocinaram alguns projetos de intervenção e de investigação, sobretudo relativas à cidade de Lisboa. ${ }^{3}$ Também a Rede Europeia Anti-Pobreza - Portugal produziu alguns estudos de caracterização a nível nacional ou sobre temáticas específicas, como por exemplo, a saúde e emprego e apoiou algumas publicações, p.e. Pinto, 2000.

Mas, é sobretudo na primeira década do século XXI que se intensifica a produção científica académica sobre os Ciganos em Portugal com o aumento substancial de dissertações de mestrado e de teses de doutoramento (p. ex. Costa 2006; Lopes, 2006; Blanes, 2006; Mendes, 2007; Casa-Nova, 2008; Magano, 2010; Montenegro, 2012; Sousa, 2010; Brinca, 2009; Nicolau, 2010; Gomes, 2013, Castro, 2012), nas áreas científicas da Sociologia, da Antropologia e das Ciências Sociais em geral.

\section{Dos primeiros levantamentos sociodemográficos e tentativas de quantificação}

O conhecimento disponível sobre Ciganos em Portugal é sobretudo de caráter qualitativo, realizado em alguns microcontextos. No entanto, é sentida a necessidade de conhecer a dimensão e caracterização das pessoas ciganas em Portugal, como forma de melhor adequar os instrumentos de políticas públicas e a intervenção de proximidade.

Em 1995, o Secretariado Diocesano de Lisboa, através da Obra Nacional para a Pastoral dos Ciganos efetua um levantamento da Comunidade Cigana na área da Diocese de Lisboa, coordenado por Fernanda Reis. Numa perspetiva de complementaridade, é de realçar a pesquisa que em 1988 o Programa de Promoção Social da Misericórdia de Lisboa levou a efeito sobre a população cigana do distrito de Lisboa.

Por sua vez, em 1998, o ACIME, na sequência da criação de um Grupo de Trabalho para a Igualdade e Inserção dos Ciganos e da aplicação de um inquérito aos municípios publica o relatório de Tratamento de dados de Inquérito. No ano de 2001, o SOS Racismo publica o relatório Ciganos, Números, abordagens e realidades, Satispen ta li - saúde e liberdade, que apresenta os resultados de um inquérito também efetuado junto das Câmaras Municipais. Em

\footnotetext{
3 Por exemplo, ONPC, 1999; Reis, 1995; Reis, 1997; Reis, 1999; Reis, 2001; Ventura, 2004.

${ }^{4}$ REAPN, 1999; REAPN, 2008; REAPN, 2009 e Pinto, 2000
} 
2007, Castro cruza a informação disponível provinda dos inquéritos do ACIME e do SOS Racismo procurando complementar a informação em falta, com o complemento de um inquérito junto da Guarda Nacional Republicana.

Também no ano de 2007 é publicado um estudo sobre os ciganos residentes na cidade de Sintra, com uma caracterização sociodemográfica exaustiva (Bastos, Correia e Rodrigues, 2007).

A REAPN, em 2009 elabora um estudo sobre as Comunidades Ciganas e a Saúde: um primeiro retrato nacional.

A Comissão Parlamentar de Ética, Sociedade e Cultura, em 2009, publica o Relatório das audições efetuadas sobre portugueses ciganos no âmbito do Ano Europeu para o Diálogo Intercultural, cujos dados serviram de suporte à elaboração da Estratégia Nacional para a Integração das Comunidades Ciganas, elaborada em 2011 e publicada no Diário da República em 2013 (ACIDI, 2013).

Já no âmbito da entrada em vigor da Estratégia Nacional para a Integração das Pessoas Ciganas, foi realizado o Estudo Nacional sobre as Comunidades Ciganas, em 2014 e que permitiu obter uma análise sincrónica sobre as caraterísticas, condições de vida, práticas sociais e valores das pessoas Ciganas (Mendes, Magano \& Candeias, 2014).

De seguida apresentamos uma sistematização das várias estimativas disponíveis sobre a dimensão demográfica da população cigana em Portugal.

\begin{tabular}{|l|c|}
\hline $\begin{array}{l}\text { OCDE, (s.d.); European Roma Center, Centre de Recherches } \\
\text { Tsiganes et Unicef, 1998) }\end{array}$ & 90 ou 100 mil \\
\hline $\begin{array}{l}\text { SOS Racismo (2001) através de um Inquérito realizado junto das Câmaras } \\
\text { Municipais }\end{array}$ & 531 \\
\hline European Commission Against Racisms and Intolerance (ERCI) (2002: 23) & 34000 60000 \\
\hline $\begin{array}{l}\text { Castro (2007) através de dois inquéritos aplicados } \\
\text { às Câmaras Municipais e à Guarda Nacional Republicana }\end{array}$ & 3400 famílias ciganas foram \\
\hline $\begin{array}{l}\text { Rede Europeia Anti-Pobreza/ Portugal, 2009 } \\
\text { nal }\end{array}$ & $\begin{array}{c}7154 \text { nacio- } \\
\text { identificadas a nível e } 60 \text { 000 }\end{array}$ \\
\hline $\begin{array}{l}\text { Estratégia Nacional para a Integração dos Ciganos em Portugal (ACIDI, 2011) } \\
\text { Estudo Nacional Sobre as Comunidades Ciganas } \\
\text { (Mendes, Magano e Candeias, 2014) }\end{array}$ & $\begin{array}{c}\text { Inquérito às autarquias e a } \\
\text { pessoas ciganas aponta para } \\
\text { o valor aproximado de } \\
24210\end{array}$ \\
\hline $\begin{array}{l}\text { Atualização feita pelo ACM em 2016 (ACM em Revista, 5, 2017). } \\
\text { 37089 }\end{array}$
\end{tabular}


No âmbito do projeto de investigação Factores-Chave para o sucesso e continuidade dos percursos escolares dos ciganos: indivíduos, famílias e políticas públicas, ${ }^{5}$ que decorreu entre 2013 - 2015 (Mendes, Magano \& Costa, 2017 e 2020), foi possível fazer um levantamento bibliográfico sobre Ciganos em Portugal, em que foram registadas 2328 referências bibliográficas, dos quais 979 são referentes ao contexto português.

Para a análise que se apresenta são considerados 920 registos, referentes aos últimos 30 anos, desde 1980 a 2013. De acordo com a catalogação das bibliotecas foram registados e sistematizados os seguintes tipos de registos: Livros técnicos e científicos (157); Capítulos em livros técnicos científicos; Artigos (205); Recensões (13); Teses (357); Comunicações em eventos (77); Relatório (28); Obras literárias (13); Catálogos e brochuras (7); Registo sonoro, visual e audiovisual (19); Outros documentos (4).

É visível o aumento significativo de teses elaboradas e de artigos disponíveis sobre ciganos em Portugal, detetando-se um acentuado crescimento de 2010 a 2013, sobretudo na área de educação; exclusão e inclusão social e interculturalismo, multiculturalismo e mobilidade. Pelos registos disponíveis nas bibliotecas portuguesas e nos repositórios abertos das Universidades, à data da recolha de dados, constata-se que desde o 25 Abril de 1974 há um crescimento progressivo de trabalhos sobre ciganos, sobretudo a partir de meados da década de 90. Trata-se sobretudo de pesquisas realizadas no âmbito de estudos de Mestrado e de Doutoramento, em que a temática "Educação" assume particular destaque mas regista-se, também, um incremento no número e qualidade dos estudos sobre ciganos em Portugal, que têm permitido evidenciar as diversidades existentes, bem como as lógicas que nutrem a persistência de olhares homogeneizadores sobre um grupo cujos estudos demonstram ser profundamente diverso.

O levantamento realizado evidencia algumas lacunas, designadamente, no que concerne ao conhecimento das reais condições de vida destas populações, verificando-se uma ausência de estudos longitudinais e uma falta de dados estatísticos sobre as características e condições de vida dos ciganos portugueses. Assim, constata-se que faltam estudos quantitativos e transversais que possibilitem conhecer e divulgar as realidades vividas pelos ciganos portugueses, bem como estudos que permitam aprofundar a relação entre políticas públicas e os seus impactos.

\footnotetext{
${ }^{5}$ Financiado pela Fundação para a Ciência e Tecnologia com a referência PTDC/IVC-PEC/4909/2012.
} 


\section{O hiato entre investigação científica e políticas públicas}

Os estudos mais recentes (Mendes, Magano \& Candeias, 2014; Mendes, Magano \& Costa, 2017 e 2020) proporcionaram ampliar o conhecimento sobre as pessoas ciganas em Portugal. O primeiro permitiu esboçar um diagnóstico rigoroso sobre a situação social das pessoas ciganas; o segundo contribuiu para perceber quais os fatores que mais contribuem para o sucesso e continuidade dos trajetos escolares entre os jovens ciganos. O mais importante, é que ambos os estudos revelam diferenças culturais, sociais e regionais o que é importante para desconstruir uma narrativa de estereotipia e tentativas de homogeneização (Mendes, 2007; Magano, 2010; Nicolau, 2010; Mendes, Magano \& Candeias, 2014; Assunção, 2019; Medinas, 2018; Pereira, 2016; Pinto, 2017).

Os estudos disponíveis possibilitam também a identificação e caracterização das situações de pobreza, pouca escolaridade, desqualificação profissional, falta de formação profissional, desemprego, e segregação espacial e social, apesar de se registarem diferenças regionais e ser essencial des-homogeneizar o olhar sobre os ciganos portugueses (Mendes, Magano \& Candeias, 2019). No Estudo Nacional sobre as Comunidades Ciganas (Mendes, Magano \& Candeias, 2014) são apontados os elevados níveis de analfabetismo ou a parca escolaridade (em 1599 inquiridos em Portugal continental 52\% não completaram ou não frequentaram o $1^{\circ}$ ciclo do ensino básico; 53\% completou apenas o ensino básico, sendo quase irrisórios os valores de conclusão do ensino secundário ou ensino superior). No que se refere às fontes de rendimento $33,5 \%$ dos inquiridos vivem da prestação de Rendimento Social de Inserção ou a cargo da família 33,8\%, sendo elevadas as percentagens de desempregados 28,6\%. Outro resultado bastante preocupante prende-se com o facto de alguns inquiridos terem declarado que a sua família passou por dificuldades, não dispondo de alimentos suficientes em que cerca de $48 \%$ indicou ter passado fome, situação mais recorrente entre indivíduos menos escolarizados (não sabe nem escrever) e mais velhos (é em pessoas com mais de 65 anos que se observam situações mais extremas).

Num outro estudo realizado nas áreas metropolitanas do Porto e de Lisboa ${ }^{6}$, em 6 territórios habitacionais (3 em cada área) foi possível apurar, através de entrevistas a técnicos e a residentes ciganos, que a questão da pouca escolaridade é um problema que persiste e que condiciona as possibilidades de aceder ao mercado de trabalho, verificando-se que o Rendimento Social de Inserção é a prestação social que permite que as famílias consigam sobreviver mas não as pre-

\footnotetext{
${ }^{6}$ Já referido anteriormente. Trata-se do projeto Factores-chave para o sucesso e continuidade dos percursos escolares dos ciganos: indivíduos, famílias e políticas públicas que decorreu entre 2013-2015.
} 
para para a inserção no mercado de trabalho nem para a autonomia financeira, nos leva a questionar o impacto de políticas públicas no efetivo empoderamento destas famílias (Mendes, Magano \& Costa, 2020; Mendes, Magano \& Costa, 2017; Magano \& Mendes, 2016). Relativamente aos níveis de escolaridade das pessoas ciganas entrevistadas nestes territórios, na AML $22 \%$ não sabe ler nem escrever; $25 \%$ tem o $1^{\circ}$ ciclo incompleto; $17 \%$ tem o $1^{\circ}$ ciclo, ou seja $64 \%$ têm o $1^{\circ}$ ciclo ou menos e na AMP $21 \%$ não sabe ler nem escrever; $11 \%$ tem o $1^{\circ}$ ciclo incompleto e $18 \%$ o $1^{\circ}$ ciclo, isto é $50 \%$ dos entrevistados têm o $1^{\circ}$ ciclo ou menos.

A mesma tendência é revelada através de relatórios produzidos por agências internacionais que continuam a referenciar as pessoas ciganas como as mais pobres e excluídas entre as quais se incluem os ciganos residentes em Portugal (FRA 2012, FRA 2014; FRA, 2017).

Em termos ilustrativos, no que se refere à situação perante o trabalho, de acordo com evidências empíricas derivadas do EU.MIDIS II ${ }^{7}$ é revelado que apenas $1 / 4$ dos entrevistados se considera "empregado", sendo que a taxa de risco de pobreza entre os ciganos é de $80 \%$ nos 9 Estados-Membros em que o estudo foi realizado, entre os quais Portugal. Com efeito, a melhoria da situação dos ciganos face à educação, emprego, habitação e saúde, continua a ser pouco visível e impactante tendo em conta a implementação das estratégias nacionais de integração das comunidades ciganas (FRA, 2017). De um modo geral, as pessoas ciganas encontram-se numa posição de desvantagem quando competem por um emprego, não só devido à falta de credenciais escolares e profissionais, mas também porque por vezes são discriminados (FRA, 2012; Pereira, 2016). Estamos perante pessoas e famílias marcadas por um ciclo incontornável de perpetuação de desigualdades de oportunidades, práticas discriminatórias e aspirações não concretizadas, muitas vezes em situação de "enclave cultural” (O’Neill, 2012), de "aprisionamento territorial e cultural" ou vítimas de uma extrema "hiperguetização" (Wacquant, 2014) para além de vítimas de segregação e de discriminação institucional (Araújo, 2019).

Contudo, também há cada vez mais estudos que se descentram desta temática, abordando questões como a empregabilidade e formação profissional (Pereira, 2016), a habitação e o direito à cidade (Pinto, 2017; Assunção, 2019), os usos das TIC e das redes digitais (Medinas, 2018) assim como os fatores que facilitam ou são constrangimentos para a continuação de percursos escolares mais longos (Mendes \& Magano, 2016; Mendes, Magano \& Costa 2017 e 2020).

\footnotetext{
${ }^{7}$ A FRA realizou em 2016 o segundo Inquérito às Minorias e Discriminação (EU-MIDIS II) na União Europeia que reuniu informações sobre quase 34 mil pessoas de origem cigana em nove Estados-Membros: Bulgária, República Checa, Grécia, Hungria, Polónia, Portugal, Roménia, Eslováquia e Espanha.
} 
Os resultados dos vários estudos permitem de igual modo identificar as interações sociais em vários contextos e que muitas vezes se pautam por representações sociais negativas, comportamentos racistas e de discriminação face às pessoas ciganas (Mendes, 2007; Silva, 2015), mesmo quando estão integradas sob o ponto de vista da inserção no mercado de trabalho por conta de outrem e são altamente escolarizados (Magano, 2010 e 2014).

Cada estudo revela um recorte temático determinado e debruça-se sobre determinados segmentos da população cigana, essa visão aproximada permite-nos aceder a conhecimento qualificado sobre modos de vida e pertenças culturais, muitas vezes, distanciando-se do conhecimento estereotipado e dicotómico considerando que as pessoas ciganas não estão "engessadas" no tempo: as suas vidas são dinâmicas e acompanham as transformações sociais e culturais da sociedade em que vivem (Cunha \& Magano, 2019).

Apesar de o Estudo Nacional (Mendes, Magano \& Candeias, 2014) ter permitido esboçar um retrato sobre a situação dos ciganos em Portugal seria importante dar continuidade à recolha de informação sobre as condições de vida, uma vez que faltam estudos comparativos (nacionais e transnacionais e longitudinais, de forma a estimular novos olhares sobre as realidades estudadas, bem como estudos multidisciplinares e multissectoriais.

Apesar da diversidade de temáticas identificadas, outras continuam por explorar como, por exemplo, as migrações, as expressões culturais e artísticas, a presença crescente nas redes sociais, o acesso à sociedade de conhecimento, a violência doméstica, a saúde, entre outras.

Em síntese e concluindo, na verdade, o conhecimento produzido tem vindo a aumentar de forma substancial desocultando situações desigualitárias e discriminatórias em que vivem pessoas ciganas em Portugal sobretudo no que se refere à habitação, pobreza, racismo, segregação espacial e social, escolarização, emprego e formação profissional mas também são reveladas novas oportunidades especialmente para as gerações mais jovens e a exploração de diferentes temáticas estudadas. Os resultados obtidos através dos vários estudos disponíveis são fundamentais para a justificação e sustentação de programas e de medidas de política pública, embora frequentemente não seja aproveitado por parte dos atores e decisores políticos, ou seja, persiste um hiato entre o conhecimento produzido e a efetiva utilização na implementação de políticas públicas. 


\section{Bibliografia}

ACIME (1998). Relatório do Grupo de Trabalho para a Igualdade e Inserção dos Ciganos. Lisboa: Presidência do Conselho de Ministros - Alto Comissário para a Imigração e Minorias Étnicas/ ACIME.

ACIDI. (2013). Estratégia Nacional para a Integração dos Ciganos. Lisboa: ACIDI

ACM (2017). Aprofundamento do estudo sobre as comunidades ciganas. ACM/ OBCIG. ACM em Revista. Diálogo Inter-Religioso: 35-40. https://issuu.com/acmemrevista/docs/acm_emrevista_5_digital

Alfaro, A. G., Costa, E.M. L., \& Floate, S. S. (1999). Ciganos e degredos. Os casos de Portugal, Espanha e Inglaterra, séculos XVI - XIX. Lisboa: Centre de Recherches Tsiganes.

Araújo, M. (2019). À procura do "sujeito racista”: a segregação da população cigana como caso paradigmático. Cadernos do Lepaarq, v. XVi, n.31., Jan-Jun: 147-162

Assunção, M. J. (2019). Estudo sobre os ciganos residentes em acampamentos na cidade de Évora. Dissertação de Mestrado em Relações Interculturais. Lisboa: Universidade Aberta.

Braga, T. (1879). Origem dos ciganos. O Positivismo, $\mathrm{n}^{\circ} 4$.

Bastos, J. G. P. (Ed.). (2012). Portugueses ciganos e ciganofobia em Portugal. Lisboa: Edições Colibri.

Bastos, J. G. P., Correia, A. C., Rodrigues, E. (2007). Sintrenses ciganos. Uma abordagem estrutural-dinâmica. Lisboa: Câmara Municipal de Sintra e ACIDI

Brinca, A. (2009). "Os ciganos gostam de dar nas vistas, serem falados e gabados": exibição e manejo do segredo como estratégia de representação de portugueses ciganos. Tese de doutoramento em Antropologia Cultural e Social. Universidade Nova de Lisboa: Faculdade de Ciências Sociais e Humanas.

Blanes, R. (2006). Aleluia! Música e Identidade num Movimento Evangélico Cigano na Península Ibérica. Lisboa: Imprensa de Ciências Sociais.

Branco, F. (2003). Os ciganos e o RMG: Direitos sociais e direito à diferença. Intervenção Social, 27: 21-143.

Brazzabeni, M. (2012). “De bairro em bairro: uma família cigana em Vila Real de Santo António entre discriminação burocrática e social e possíveis formas de vida". In J. Bsstos (ed.). Portugueses Ciganos e Ciganofobia em Portugal. Lisboa: Colibri. Pp. 267-278

Casa-Nova, M. J. (2008). Família, Etnicidad, Trabajo y Educación. Estudio etnográfico sobre los modos de vida de una comunidade gitana del Norte de Portugal, Tese de doutoramento. Departamento de Antropologia Social. Granada: Universidade de Granada

Casa-Nova, M. J. (2009). Etnografia e Produção de Conhecimento - Reflexões críticas a partir de uma investigação com ciganos portugueses, Lisboa: ACIDI

Castro, A. (1995). Ciganos e Habitat: entre a itinerância e a fixação. Sociologia, Problemas e Práticas, 17: 97-111 
Castro, A. (2007). Dos Contextos Locais à lnvisibilização Política - Discussão em torno dos ciclos de exclusão habitacional dos ciganos em Portugal. Cidades, Comunidades e Territórios, 15: 63-86.

Castro, A. (2012). Na luta pelos bons lugares. Ciganos, visibilidade social e controvérsias espaciais. Tese de doutoramento em Antropologia, especialidade Antropologia Urbana, Lisboa: Iscte.

Coelho, A. (1995 [1892]). Os ciganos de Portugal: com um estudo sobre o calão (1 ${ }^{\mathrm{a}}$ ed. ed.). Lisboa: Publicações D. Quixote.

Comissão Parlamentar de Ética, Sociedade e Cultura - Sub-comissão para a Igualdade de Oportunidades e Família (2009). Relatório das Audições efectuadas sobre portugueses ciganos no âmbito do Ano Europeu para o diálogo Intercultural.

Costa, A. B., \& Pimenta, M. C. (1991). Minorias Étnicas Pobres em Lisboa. Lisboa: Centro de Reflexão Cristã - Departamento de Pesquisa Social.

Costa, E. M. (1995). Os ciganos em Portugal: breve história de uma exclusão. In Cortesão, L.; \& Pinto, F. (org.). O povo cigano: cidadãos na sombra-Processos explícitos e ocultos de exclusão. Porto: Ed. Afrontamento. Pp. 21-26.

Cortesão, L., Stoer, S., Casa-Nova, M. J. \& Trindade, R. (2005). Pontes para outras viagens escola e comunidade cigana: representações recíprocas. Lisboa: ACIME.

Costa, E. M. L. (1995). Os ciganos. Fontes bibliográficas em Portugal. Madrid: Centro de Investigaciones Gitanas / Editorial Presencia Gitana

Costa, E.M. L. (1996). O Povo Cigano em Portugal: Da História à Escola - Um Caleidoscópio de informações. Setúbal: Instituto Politécnico de Setúbal - Escola Superior de Educação.

Costa, M. A. A. (2006). Ciganos: histórias de vida. Coimbra: Minerva Coimbra.

Cunha, J. \& Magano, O. (2019). Ciganas e ciganos no Brasil e Portugal: uma análise comparativa acerca dos processos de integração e construção de políticas sociais. Revista Anthropológicas. Ano 23, 30 (1) :251-280

Dias, E.C., Alves, I., Valente, N., \& Aires, S. (2006). Comunidades ciganas: representações e dinâmicas de exclusão-integração (Vol. 6). Lisboa: ACIME.

ERCI (2002). Segundo Relatório sobre Portugal, European Commission Against Racisms and Intolerance, adoptado em 20 de Março de 2002, Estrasburgo.

Fonseca, E. P.; Marques, J. M. \& Poeschi, G. (2005). Representações sociais das comunidades ciganas e não-ciganas. Porto: ACIME.

FRA (2012). The situation of Roma in 11 EU Member States Survey results at a glance. Luxembourg: Publications Office of the European Union.

FRA (2014). Roma survey - Data in focus. Education: the situation of Roma in 11 EU Member States. Luxembourg. European Union Ageny for Fundamental Rights

FRA (2017). Second European Union minorities and discrimination survey. Technical report. Luxembourg: Publications Office of the European Union. 
Fundación secretariado General Gitano / Satispen / REAPN (1999). Actuar com a comunidade cigana - orientações para a intervenção em toxicodependência a partir dos serviços de assistência. (1999). Porto: Fundación secretariado General Gitano / Satispen / REAPN

Gomes, S. (2013). Criminalidade, Etnicidade e Desigualdades: Análise comparativa entre os grupos nacionais dos PALOP e Leste Europeu e o grupo étnico cigano. Tese de Doutoramento, Braga, Instituto de Ciências Sociais da Universidade do Minho.

Jorge, A. C. (2007). Interculturalidade e desenvolvimento de comunidades ciganas. a experiência do projecto nómada. Cadernos ICE, 9: 15-20.

Lopes, D. S. (2006). Deriva cigana. Uma etnografia impressionista. (doutoramento em antropologia), Universidade Nova de Lisboa. Faculdade de Ciências Sociais e Humanas, Lisboa

Lopes, D. S. (2008). Deriva cigana: um estudo etnográfico sobre os ciganos de Lisboa. Lisboa: Imprensa de Ciências Sociais.

Magano, O. (1999). Entre ciganos portugueses: estudo sobre a integração de uma comunidade cigana residente na cidade do Porto. Porto: Universidade Aberta. Dissertação em Relações Interculturais

Magano, O. (2010). Tracejar Vidas Normais. Estudo Qualitativo sobre a Integração Social de Indivíduos de Origem Cigana na Sociedade Portuguesa.Tese de doutoramento em Sociologia. Lisboa: Universidade Aberta.

Magano, O. (2014). Tracejar vidas 'normais'. Estudo Qualitativo sobre a Integração dos ciganos em Portugal. Lisboa, Editora Mundos Sociais.

Magano, O. \& Mendes, M. M. (2014). Ciganos e políticas sociais em Portugal, Sociologia, Revista da Faculdade de Letras da Universidade do Porto, Número temático - Ciganos na Península Ibérica e Brasil: estudos e políticas sociais: 15-35.

Magano, O. \& Mendes, M. M. (2016). “Constrangimentos e oportunidades para a continuidade e sucesso das pessoas Ciganas". Revista Configurações 18. Ciganos e Educação: 8-26.

Medinas, C. (2018). Ciganos e Literacia digital: estudo de caso em Reguengos de Monsaraz. Dissertação de Mestrado em Relações Interculturais. Lisboa: Universidade Aberta.

Mendes, M. M. (1997). Etnicidade, grupos étnicos e relações multiculturais, no âmbito de uma Sociologia das Relações Étnicas e Rácicas. Tese de Mestrado em Sociologia. Porto: Faculdade de Letras da Universidade do Porto.

Mendes, M. M. (2007), Representações Face à Discriminação. Ciganos e Imigrantes Russos e Ucranianos na Área Metropolitana de Lisboa, Tese de doutoramento em Ciências Sociais. Lisboa: Instituto de Ciências Sociais,

Mendes, M. M. (2012). Identidades, Racismo e Discriminação: ciganos da AML, Lisboa, Caleidoscópio.

Mendes, M. M., Magano, O. \& Candeias, P. (2014). Estudo Nacional sobre as Comunidades Ciganas. Lisboa: Alto Comissariado para as Migrações 
Mendes, M. M.; Magano, O. \& Candeias, P. (2019). Des-homogeneizar os Ciganos Portugueses: perfis sociais e heterogeneidade sócio-cultural. OBETS. Revista de Ciencias Sociales, 14(1): 49-87.

Mendes, M. M., Magano, O. \& Costa, A. R. (2017). Public policies and social change: the case of the success and continuity of schooling paths of Ciganos (Portuguese Gypsies). Portuguese Journal of Social Science. Vol. 16. Number 2: 246-265.

Mendes, M. M.; Magano, O. \& Costa, A. R. (2020). Ciganos Portugueses. Escola e mudança social. Sociologia, Problemas e Práticas, 93, 109-126.

Mendes, M. M. \& Magano, O. (2016). School pathways and economic practices of Portuguese Ciganos: some continuities and changes. Social Identities: 1-16. doi: 10.1080/13504630.2016.1186537

Montenegro, M. (2012). Aprender a ser cigano, hoje: empurrando e puxando fronteiras, Lisboa, Tese de doutoramento em Educação (Educação de Adultos). Universidade de Lisboa - Instituto de Educação

Nicolau, L.(2010). Ciganos e Não Ciganos em Trás-os-Montes: Investigação de um Impasse Interétnico. Tese de doutoramento em Ciências Sociais, Vila Real, Universidade de Trásos-Montes e Alto Douro.

Nunes, O. (1996). O Povo Cigano. Porto: Livraria Apostolado da Imprensa.

OCDE (s.d.). Gypsy population and their movement within Central and Estern Europe and towards some OCDE countries. Vol. III, n. ${ }^{\circ}$ 9. Paris. Organisation for Economic Co-operation and development.

O’Neill, B. J. (2012). “Des-guetizando ciganos, comparando minorias”. In A. I. Afonso (Ed.), Etnografias com Ciganos. Diferenciação e resistência cultural. Lisboa: Edições Colibri. Pp. 189-222.

ONPC. (1995). A comunidade cigana na área da Diocese de Lisboa. Lisboa: Secretariado Diocesano de Lisboa.

ONPC. (1999). O jovem cigano e a formação - atitudes e expectativas face ao mercado de trabalho. Lisboa: Secretariado Diocesano de Lisboa da Obra Nacional da Pastoral dos Ciganos.

Pereira, Isabel (2016). Ninguém dá trabalho aos ciganos! - Estudo qualitativo sobre a (des)integração dos ciganos no mercado formal de emprego. Dissertação de mestrado,Universidade Aberta,Lisboa,Portugal.

Peixoto, Rocha [1897] 1967. Os ciganos em Portugal. In R. Peixoto, Obras, Vol. 1. Póvoa de Varzim: Câmara Municipal da Póvoa de Varzim.

Pinto, Paula (2017). O Terceiro bairro - Estudo qualitativo sobre o impacte do rendimento social de inserção nos modos de vida de pessoas ciganas. Dissertação de mestrado em Dissertação de Mestrado em Intervenção Social, Inovação e Empreendedorismo apresentada à Faculdade de Psicologia e de Ciências da Educação. 
Pinto, F. (1995). Etnia cigana - realidade socio-cultural múltipla e dinâmica. In Cortesão, Luíza \& Pinto, Fátima (org.). O Povo Cigano: cidadãos na sombra - Processos explícitos e ocultos de exclusão. Porto: Ed. Afrontamento. Pp. 37-52

Pinto, F. (2000). A Cigarra e a Formiga - Contributos para a Reflexão Sobre o Entrosamento da Minoria Étnica Cigana na Sociedade Portuguesa. Porto: REAPN - Rede Europeia Anti-Pobreza/ Portugal.

REAPN. (2008). Guia de motivação para o desenvolvimento pessoal e profissional das mulheres ciganas. Porto: REAPN

REAPN. (2009). As comunidades ciganas e a saúde: um primeiro retrato nacional. Porto: REAPN.

Reis, F. (Ed.). (1995). A Comunidade Cigana na área da Diocese de Lisboa. Lisboa: Secretariado Diocesano de Lisboa. Obra Nacional para a Pastoral dos Ciganos.

Reis, F. (1997). (coord.) Rumo ao futuro - Projecto de promoção de integração social da etnia cigana. Lisboa: Secretariado Diocesano de Lisboa da Obra Nacional para a Pastoral dos Ciganos.

Reis, F. (1999). (Coord.) O jovem cigano e a formação: atitudes e perspectivas frente ao mercado de trabalho. Lisboa: Secretariado Diocesano de Lisboa da Obra Nacional para a Pastoral dos Ciganos.

Reis, F. (2001). (Coord.) A família cigana e habitação - relação com os espaços de interior. Lisboa: Secretariado Diocesano de Lisboa da Obra Nacional para a Pastoral dos Ciganos.

Reis, F. (Ed.). ( 2001). Quadros da vida cigana: entrevistas com... Lisboa: Secretariado Diocesano de Lisboa da Obra Nacional da Pastoral dos Ciganos e Ministérios do Trabalho e Solidariedade.

Silva, L. F. (2005). Saúde / Doença é questão de cultura. Lisboa: ACIME / FCT.

SOS Racismo. (2001). Ciganos: números, abordagens e realidades. Lisboa: SOS Racismo.

Silva, M. C. (2015). Sina Social Cigana. História, comunidades, representações e instituições. Lisboa: Edições Colibri.

Sousa, C. J. (2010). Relações interculturais, dinâmicas sociais e estratégias identitárias de uma família cigana portuguesa 1827-1959. Tese de doutoramento em Sociologia, Universidade Aberta /DCSG, Lisboa.

Wacquant, L. (2014). Marginality, Ethnicity and Penality in the Neoliberal City: An Analytic Cartography. Ethnic \& Racial Studies, 37(10): 1687-1711.

Ventura, V. (2004). Ciganos na cidade. Retratos de família. Lisboa: Secretariano Diocesano de Lisboa da Obra Nacional Pastoral dos Ciganos.

Vasconcelos, J. 1. (1958). Etnografia Portuguesa. Vol. IV. Lisboa: Imprensa Nacional. 



\title{
Capítulo 2.
}

\section{Considerações metodológicas acerca de estudos quantitativos sobre pessoas ciganas. Três questões e problemas associados às suas respostas ${ }^{1}$}

\author{
PEDRO CANDEIAS ${ }^{2}$ \\ Universidade de Lisboa, ISAMB/EnviHeB lab, e ICS \\ pedromecandeias@gmail.com
}

Resumo: No campo dos estudos sobre pessoas ciganas, as metodologias quantitativas são provavelmente uma minoria. Mas mesmo nessa minoria existem diferentes abordagens. Com este artigo pretende-se refletir sobre algumas potencialidades e limitações associadas às metodologias quantitativas aplicadas a pessoas ciganas, com base no contexto português e internacional. O texto encontra-se estruturado em três questões e três respostas, que incidem, por sua vez, em três correntes de estudos. Nomeadamente: Quantos são? Qual o seu perfil sociodemográfico? Quais as atitudes da população não-cigana face aos Ciganos?

Palavras-chave: metodologias de inquéritos por questionário, atitudes sociais, efeito de bairro

\begin{abstract}
In the field of studies on Roma and Cigano people, quantitative methodologies are probably a minority. However, even in this minority there are different approaches. This paper aims to reflect on some of the potential and limitations associated with quantitative methodologies applied to Cigano people, based on the Portuguese and international context. The text is structured in three questions and three answers, which, in turn, focus on three streams of studies. Namely: How many are there? What is their sociodemographic profile? What are the attitudes of the non-Cigano population towards Ciganos?
\end{abstract}

Keywords: survey methodology, social attitudes, neighborhood effect, perceived discrimination

\footnotetext{
${ }^{1}$ Este capítulo foi produzido no âmbito do projeto EduCig Desempenhos escolares entre os Ciganos: investigaçãoação e projeto de co-design (PTDC/CED-EDG/30175/2017). Financiado pela Fundação para a Ciência e Tecnologia.

${ }^{2}$ Pedro Candeias é Licenciado e Mestre em Sociologia pelo Iscte. Atualmente é bolseiro de doutoramento no Instituto de Ciências Sociais da Universidade de Lisboa. Universidade de Lisboa, Faculdade de Medicina, Instituto de Medicina Preventiva e Saúde Pública, Instituto de Saúde Ambiental; e Instituto de Ciências Sociais. Colaborou no Estudo Nacional Sobre as Comunidades Ciganas e atualmente colabora no projeto EduCig.
} 


\section{Introdução}

Os trabalhos de investigação sobre pessoas ciganas que recorrem a metodologias quantitativas devem ser uma minoria. Mesmo não sendo conhecidas análises exaustivas que calculem a relação entre as duas grandes opções metodológicas, qualitativo e quantitativo. Mas embora se desconfie que os estudos de abordagem quantitativa sejam uma minoria, é notório que na comunicação social estes estudos gozam de elevada notoriedade. Refere-se como exemplos o Estudo Nacional das Comunidades Ciganas (Mendes, Magano, \& Candeias, 2014), e o mais recente Perfil Escolar da Comunidade Cigana (DGEEC, 2017). Não obstante esta notoriedade, desconhecem-se trabalhos de ordem metodológica sobre a população cigana em território português. Este artigo pretende lançar a discussão em torno das questões metodológicas nos estudos de abordagem quantitativa sobre as pessoas ciganas em Portugal. Para cumprir este fim, são levantadas três questões sobre Ciganos cujas respostas podem ser obtidas por via de metodologias quantitativas. Não serão aprofundadas as respostas a essas questões, mas sim a reflexão em torno da metodologia que permite dar resposta a essas indagações.

\section{Primeira questão. Quantos são?}

Frequentemente nas Ciências Sociais, estudar um fenómeno ou um grupo social, implica quantificar esse fenómeno ou grupo. Os estudos sobre Ciganos não são exceção. A resposta à questão "Quantos Ciganos existem em Portugal?" 3 apenas pode ser obtida através de estimativas. Deste modo, ao longo dos anos, têm vindo a ser propostos valores para esse quantitativo. Estas estimativas têm sido avançadas tanto por estudos académicos, como por organismos oficiais e organizações não-governamentais.

O primeiro estudo que se conhece a propor um valor para o número de Ciganos em Portugal foi o de Nunes $(1996)^{4}$. Um estudo etnográfico conduzido nos anos 1970 em que foram acompanhados diversos aglomerados habitacionais. Do levantamento etnográfico que Nunes efetuou por conta própria, foram percorridos cinco dos dezoito distritos. O autor afirmava que "Enquanto não tivermos dados documentados mais exatos que os nossos, continuamos a afirmar que a população cigana em Portugal NÃO SERÁ MUITO SUPERIOR A VINTE MIL ALMAS, não incluindo as Regiões Autónomas de Madeira e Açores” (Nunes, 1996 p.421, maiúsculas no original).

\footnotetext{
${ }^{3}$ Mais recentemente, a questão deveria ser afinada para procurar qual o número de Ciganos portugueses em Portugal, uma vez que tem observado nos últimos anos, em Portugal, como pelo resto da Europa, uma vaga relevante de imigração de Ciganos provenientes da europa de leste (Cahn \& Guild, 2010).

${ }^{4}$ Primeira edição de 1981.
} 
Figura 1. Estimativas para o número de Ciganos em Portugal e taxa de resposta

60000

40000

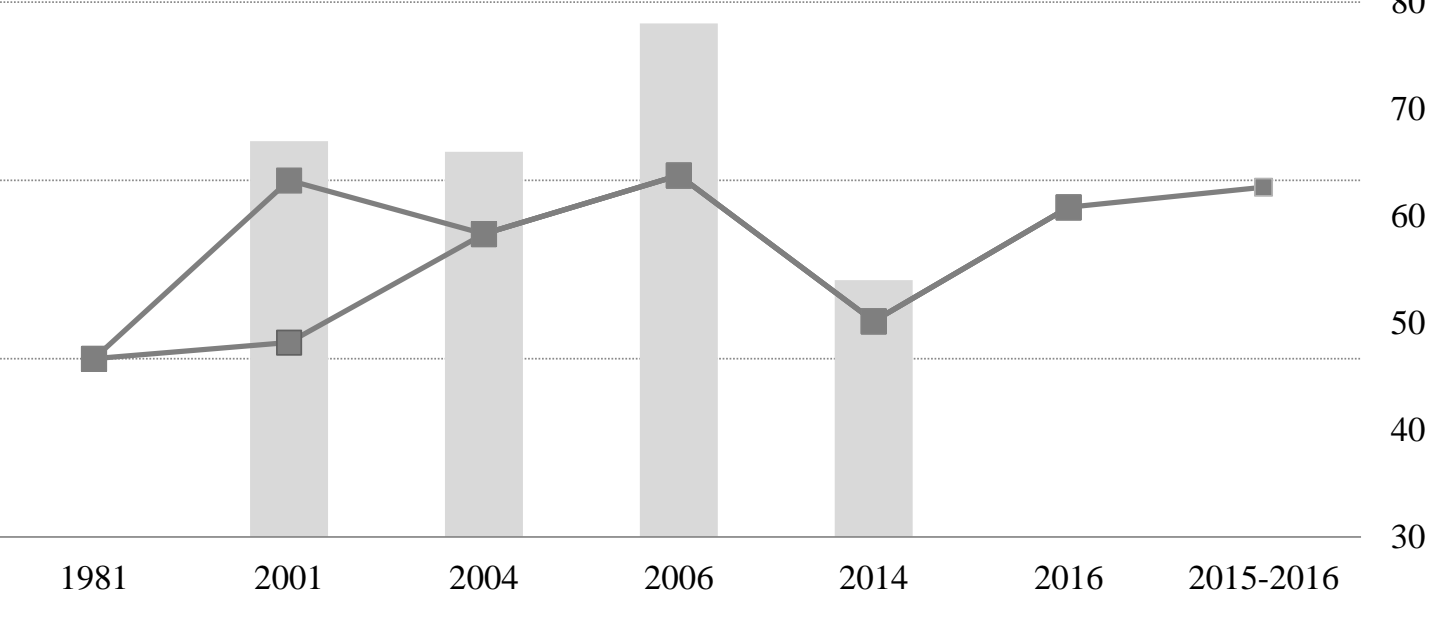

20000

\begin{tabular}{l|l}
\hline Estudo & Metodologia \\
\hline Nunes & Etnografia \\
\hline SOS Racismo & Municípios, autarquias e outros estudos \\
\hline CIT 1 & Município, SOS Racismo; Autarquias ; Segurança Social \\
\hline CIT 2 & GNR \\
\hline ENCC & Municípios \\
\hline IHRU & Municípios, \\
\hline FRA & CIT 1, Programa Mediadores Municipais, Programa Escolhas \\
\hline
\end{tabular}

Fonte: elaborado pelo autor com base em Nunes (1996),SOS Racismo (2001), CIT 1 (Castro, 2004), Mendes e colegas (2014), IHRU (2015), e FRA (2017a).

O segundo estudo a ser referido é o estudo da SOS Racismo, cujo trabalho de campo decorreu em 1996. Este trabalho foi inaugural ${ }^{5}$ no método indireto, o que é, até à data, o método mais eficaz. A estratégia consiste em solicitar os quantitativos de pessoas ciganas a organismos que possuam essa informação nos seus registos administrativos. O mais frequente é o contacto com câmaras municipais. Este método tem a vantagem de poder cobrir a totalidade do território nacional, com o risco bastante baixo de ocorrerem duplas contagens. Numa primeira fase do estudo da SOS Racismo foram contactadas as 307 câmaras existentes na altura. Posteriormente, em 1997, no âmbito do Grupo de Trabalho para a Igualdade e Inserção dos Ciganos, enquadrado

\footnotetext{
${ }^{5}$ Já no estudo de Nunes (1996) foi enviado um inquérito às sedes de concelho dos distritos. E numa segunda fase, a nível de freguesia, foram enviados questionários a párocos, professores do EB 1, GNR e outros intermediários. Embora este inquérito tivesse como objetivo conhecer o perfil sociodemográfico e sinalizar zonas de residência, e não tanto obter uma quantificação (p.42).
} 
no Alto Comissariado para as Minorias Étnicas (atual Alto Comissariado para as Migrações), o questionário foi replicado, mas para as freguesias, de um universo de 4.421, foram recebidas 1.097 respostas. Este valor correspondia a uma taxa de resposta de $67 \%$. Como se percebeu que o valor apurado iria depender da taxa de resposta, as não-respostas foram colmatadas com dados de outros estudos. Os dados conjuntos chegam a um total de 21.831 ciganos (SOS Racismo, 2001). Estudos posteriores reproduziram este primeiro trabalho, procurando aumentar a taxa de resposta. O modo de contornar esta limitação foi, muitas vezes, o de diversificar (ou substituir) as fontes de modo a obter uma cobertura nacional total.

Posteriormente, em 2001, no âmbito do projeto Ciganos, Territórios e Itinerância, (doravante CTI), foi lançado um novo questionário às câmaras municipais. Este questionário teve uma taxa de resposta de 55\% (de 278 municípios continentais). Para 44 câmaras municipais que não responderam foram reutilizados os dados obtidos pelo SOS Racismo, o que aumentou a taxa de cobertura para $65,5 \%$. Com este estudo foi contabilizado um total de 19.687 ciganos em território continental (Castro, 2004).

O projeto CIT teve uma segunda edição, em 2006 (denominado de CIT 2). Neste novo projeto foi testada uma fonte alternativa, os postos da Guarda Nacional Republicana ${ }^{6}$. Foram recolhidas 382 respostas, o que correspondia a 77\% dos 496 postos da GNR. Os postos da GNR possuem uma abrangência ao nível concelhio, embora não cubram a totalidade do território, especialmente em algumas áreas urbanas. Os dados foram complementados com os obtidos no âmbito do CIT 1, do levantamento do SOS Racismo e outros documentos, cobrindo um total de 75,5\% do território nacional (Castro, 2016). O total do valor apurado foi de 40.568.

No ano de 2014, foi conduzido e publicado o Estudo Nacional sobre as Comunidades Ciganas (doravante ENCC) (Mendes et al., 2014). Este projeto fazia parte das metas a atingir no âmbito da Estratégia Nacional para Integração das Comunidades Ciganas de 2013 a 2020 (ACIDI/GACI, 2013). No âmbito deste estudo foram lançados inquéritos por questionário a todas as câmaras municipais (exceptuando as regiões autónomas), sem ter recorrido a nenhum tipo de imputação de respostas, isto é, sem se ter recorrido a outros estudos para colmatar as não respostas. Foi apurado um somatório de 24.210 ciganos num total de 54\% do território continental.

Concomitante como o ENCC, o Instituto da Habitação e da Reabilitação Urbana (doravante IHRU) levou a cabo, juntamente com o Alto Comissariado para as Migrações, um estudo que teve como objetivo conhecer as condições habitacionais das comunidades ciganas portuguesas.

\footnotetext{
${ }^{6}$ Inicialmente a ideia era questionar também a PSP, contudo o Gabinete de Comunicação e Relações Públicas da Política de Segurança Pública não deu resposta à equipa de investigação.
} 
Para cumprir este fim recorreu a dados de um inquérito a autarquias. Em termos de cobertura o estudo do IHRU apenas não conseguiu auscultar 5 municípios $(n=308)$. O valor apurado foi de 30.737 e foi estimado que se fossem incluídos os municípios que não responderam, o valor devia atingir os 37.346, tendo como valor de referência o valor médio de ciganos por população residente (IHRU, 2015).

Uma última estimativa foi proposta pela European Union Agency for Fundamental Rights (doravante FRA) cujo trabalho de campo decorreu entre 2015 e 2016. Neste estudo foi estimado um valor de 39.233 pessoas ciganas (FRA, 2017b) com base em estudos anteriores. Esta estimativa tinha como objetivo calcular um universo de estudo para posteriormente aplicar um inquérito por questionário a uma amostra. Essa amostra foi definida com base no estudo piloto de 2011, que por sua vez, baseou a sua amostra nos estudos CIT 1 e CIT 2, socorreu-se ainda de estimativas que decorreram dos programas Escolhas e dos Mediadores Municipais (FRA, 2013).

Para além dos valores avançados por estes estudos existem também quantitativos de Ciganos que são apontados sem um metodologia explícita, ou com metodologias que podem ser consideradas duvidosas. Dois exemplos: valores apontados pelo European Roma Center, Minority Rights Group, Centre de Recherches Tsiganes e UNICEF citados em Moutouh (2000) apontavam para um intervalo entre 50.000 e 100.000 sem referir a fonte. Um segundo exemplo é o country profile de Portugal no site do Minority Rights Group International ${ }^{7}$ que referia que, segundo os Censo de 2011, Portugal tinha entre 30 mil a 70 mil ciganos.

Desde o final dos anos 1990 que têm vindo a decorrer quantificações do número de Ciganos em Portugal com base no que se considera o método indireto (uma síntese em forma de gráfico encontra-se na Figura 1. Três considerações surgem associados a este método. Primeiro, as câmaras municipais, as mais frequentemente inquiridas acerca do número de pessoas ciganas residentes, não possuem estes registos para satisfazer interesses académicos. No processo de inquirição que o autor fez parte no âmbito do ENCC, cedo se percebeu que as respostas das câmaras municipais chegavam encaminhadas, quase exclusivamente, de duas fontes: os departamentos de habitação social, ou os departamentos de ação social. Assim, em primeiro lugar, para os casos em que existe um valor, esses números não dizem respeito aos Ciganos que vivem nesse concelho, mas sim aos Ciganos que nesse conselho são beneficiários de habitação social ou de algum outro tipo de apoio social, o que exclui indivíduos que não estão nesta situação. $\mathrm{O}$ à priori (oculto) em que assentam estas quantificações é o de que existe uma sobreposição entre Cigano e beneficiário de apoios sociais. E, como refere Castro (2016) “podemos estar a ter por

\footnotetext{
${ }^{7}$ https://minorityrights.org/country/portugal/ (consultado a última vez a 19-07-19).
} 
referência o universo dos ciganos mais vulneráveis, caindo-se no perigo de confundir a etnicidade com vulnerabilidades sociais e agravando-se inadvertidamente a estigmatização.” (p.40).

Dado este critério de contagem, ou a natureza deste indicador, a leitura deve ter sempre em conta que qualquer das estimativas acima apontadas não traduz o número de Ciganos em Portugal naquele marco temporal. Ilustrando com o caso do ENCC, a leitura deverá frisar que existem em Portugal 24.210 pessoas ciganas nos registos de habitação social ou serviços sociais. Tendo em conta que nem todos os concelhos responderam, a leitura deve ser retificada, referindo que em 149 dos 308 concelhos de Portugal continental existe 24.210 pessoas ciganas que são beneficiários de apoios sociais. Este valor será sempre um valor por defeito uma vez que não são consideradas quaisquer pessoas ciganas que não sejam beneficiários destes apoios sociais.

A segunda consideração que é apontada a este indicador é que, como se pode constatar pela Figura 1., a contagem depende do número de concelhos que são abrangidos, o que fez como que se desse início a uma diversificação de fontes. Tal é legítimo, uma vez que se obteriam valores mais próximos da realidade. Contudo, a diversificação das fontes leva à inexistência de um denominador comum. Ou seja, deixa-se de poder se falar em $\mathrm{N}$ pessoas abrangidas por benefícios sociais, para se falar em $\mathrm{N}$ pessoas ciganas em algum tipo de registo administrativo.

Em terceiro lugar, é de referir que a taxa de resposta pode depender da origem do estudo. $\mathrm{O}$ único exemplo de estudo que tem origem num instituto público é também o que teve a mais elevada taxa de resposta. O que leva a crer que a colaboração das câmaras municipais em processos de inquirição pode depender do tipo de interlocutor.

Uma alternativa ao método indireto que tem vindo a ser pensada é a inclusão da questão da pertença étnica nos censos. A questão tem levantado debate na esfera pública e não é uma questão que seja tomada de ânimo leve. Uma vez que este texto é focado na metodologia, são deixados de parte os argumentos de ordem étnica ou política. Questionar a pertença étnica diretamente num recenseamento da população iria ultrapassar limitações associadas ao método indireto, uma vez que se teria uma cobertura total do território nacional e uma uniformização de critério (a resposta à questão no recenseamento). Deste modo, iria passar-se de uma heteroidentificação de especialistas (o método que tem sido utilizado até agora) para uma autoavaliação (Ahmed, Feliciano, \& Emigh, 2007; Ladányi \& Szelényi, 2001), em que o inquirido declara a sua etnicidade a um inquiridor do INE. A palavra sobre quem é que e quem é que não é Cigano deixava de estar em técnicos e trabalhadores administrativos, para estar nos próprios indivíduos ciganos. Contudo, não é uma estratégia que se encontre livre de limitações. A pertença ética é algo pessoal e ninguém é obrigado a declará-la ao um inquiridor do INE (ou a qualquer outra 
pessoa). Segundo a FRA (2013), mesmo em países em que existe a questão da pertença ética nos censos, nem toda as pessoas se encontram disponíveis para declarar a sua etnicidade, muitas vezes com receio de perseguição, o que significa que, por defeito, as minorias (não só as ciganas) estarão sempre subestimadas nos censos (Kertesi \& Kézdi, 2011). Em países em que é questionada a origem étnica no Censo é conhecido que o universo dos autoidentificados como Ciganos é tendencialmente menor do que dos heteroidentificados. Mas o intervalo em que o primeiro grupo se posiciona também varia. Em situações em que pode existir algum risco de ser associado a esta categoria, os valores irão diminuir, se houver algum benefício, irão aumentar, o que é definido como etnicidade estratégica (Ivanov, Kling, \& Kagin, 2012)(e que não se aplica só aos Ciganos).

No caso dos Ciganos portugueses, não é possível prever qual seria a adesão à questão incluída no Censo. O debate que chegou à esfera pública parece apontar para posições nos dois espectros. E por isso, não é possível retirar algum tipo de conclusão ou previsão. De qualquer modo, pode-se afirmar com alguma confiança que a contabilização no Censo seria sempre por defeito. Uma vez que se espera que hajam sempre casos de "falsos negativos" pessoas ciganas que não se identificariam como tal no momento censitário. Mas é pouco provável que existam "falsos positivos", isto é, pessoas que não são/ou não se consideram ciganas e respondem afirmativamente à questão no Censo (Ivanov et al., 2012). É crítica comum em qualquer país em que existe a questão da filiação étnica nos censos que ela não é relaiable (Fleck \& Rughiniş, 2008). Em suma, a contabilização pecará sempre por defeito. A leitura será sempre: pelo menos, existem N Ciganos portugueses em Portugal.

\section{Segunda questão. Qual o seu perfil sociodemográfico?}

A segunda questão também é bastante comum nas ciências sociais. Ao estudar determinado grupo social, importa conhecer o seu perfil em demográfico e socioprofissional. Percorrem-se alguns estudos de modo a contextualizar os leitores com o tipo de estudos em causa. O que estes estudos têm em comum é que se tratam de trabalhos que procuraram conhecer o perfil sociodemográfico através do método direto de inquirição a pessoas ciganas. Uma vez que existem diversos estudos nesta categoria e o objetivo não é o de fazer um levantamento exaustivo, foram escolhidos os mais extensivos. Foram utilizados alguns parâmetros de análise dos trabalhos selecionados: o critério utilizado para o desenho da amostra, a abrangência territorial e a dimensão da amostra. Uma síntese destes trabalhos encontra-se na Tabela $1 .$. 
Tabela 1. Caraterísticas de estudos sociodemográficos sobre Ciganos

\begin{tabular}{|c|c|c|c|c|}
\hline & $\begin{array}{l}\text { Fundación } \\
\text { Secretariado } \\
\text { Gitano REAP } \\
\text { 2007-2008 }\end{array}$ & $\begin{array}{l}\text { FRA } \\
2011-2012\end{array}$ & $\begin{array}{l}\text { ENCC } \\
2014\end{array}$ & $\begin{array}{l}\text { FRA } \\
2017\end{array}$ \\
\hline $\begin{array}{l}\text { Definição da } \\
\text { amostra } \\
\text { e processo } \\
\text { de inquirição }\end{array}$ & & $\begin{array}{l}\text { Random-route } \\
\text { CIT } 1 \text { Programa Es- } \\
\text { colhas Programa } \\
\text { Mediadores Munici- } \\
\text { pais }\end{array}$ & $\begin{array}{l}\text { Adaptive cluster } \\
\text { sampling. ENCC, } \\
\text { CIT I e II, REAP, } \\
\text { REHURB }\end{array}$ & $\begin{array}{l}\text { Random-route } \\
\text { FRA 2011-2012 }\end{array}$ \\
\hline $\begin{array}{l}\text { Cobertura } \\
\text { territorial }\end{array}$ & 12 distritos & $\begin{array}{l}2 / 3 \text { residentes em } \\
\text { áreas urbanas }\end{array}$ & $\begin{array}{l}68 \text { concelhos } \\
18 \text { distritos }\end{array}$ & $\begin{array}{l}\text { Inquirição em áreas } \\
\text { com mais de } 60 \\
\text { agregados familiares } \\
\text { ciganos e concentra- } \\
\text { ção superior a } 5 \%\end{array}$ \\
\hline Amostra & 360 & $\begin{array}{l}1.102 \text { ciganos }+501 \\
\text { não ciganos }\end{array}$ & 1.599 & 553 \\
\hline
\end{tabular}

Fonte: REAPN (2009), FRA (2013), ENCC (2014), FRA (2017b).

O primeiro estudo a ser referido é o da Rede Europeia Anti-Pobreza (doravante REAPN). Este estudo desenhou a amostra com base num questionário enviado aos dezoito Núcleos Distritais da Rede Europeia Anti-Pobreza de Portugal, onde solicitavam os números de famílias e os concelhos de residência. Por motivos de fiabilidade financeira a amostragem incidiu nos distritos com maior presença de Ciganos no seu território. Os territórios abrangidos foram diversificados no que respeita a sua posição na relação rural-urbano e também nos diferentes tipos de habitação. Foram cobertos 12 dos 18 distritos e a amostra incidiu em 367 pessoas (REAPN, 2009).

O segundo estudo nesta secção tem como origem a European Union Agency for Fundamental Right (doravante FRA), que lançou, em 2013, um estudo piloto cujo objetivo foi conhecer as condições de vida dos Ciganos num conjunto de países europeus. $\mathrm{O}$ estudo assume-se como representativo de Ciganos a viverem em zonas de elevada concentração, mas não do total desta população. As zonas de baixa concentração foram evitadas devido aos custos elevados e ao tempo que teria que ser despendido (FRA, 2013). O estudo em Portugal incidiu em $1.102 \mathrm{Ci}$ ganos e 501 não-Ciganos. O critério de seleção implicou uma seleção aleatória de 100 territórios onde a equipa de inquiridores iniciava o random-route. Zonas de baixa concentração eram abandonadas e zonas de elevada concentração eram reforçadas (FRA, 2013). 
O terceiro estudo a ser referido é o ENCC. Neste trabalho, a amostragem recorreu aos dados primários recolhidos junto dos municípios no âmbito do projeto. As não respostas por parte dos municípios foram imputadas com recurso a dados de projetos anteriores, como os CIT, o projeto da REAP ou o REHURB ${ }^{8}$. Posteriormente, dentro de cada concelho, as zonas de residência foram sinalizadas por especialistas. Foram cobertos 68 concelhos e a totalidade dos distritos, e foram recolhidos 1.599 questionários (Mendes et al., 2014).

O último estudo a ser referido é uma continuação do estudo desenvolvido em 2013 pela FRA (2017a). Este novo inquérito foca os temas da percepção de discriminação e baseou a sua amostra na mesma técnica que o estudo de 2013. Tal como na edição anterior, aplicou o random rout com preferência por zonas com elevada concentração de pessoas ciganas, nesta vaga foram inquiridos 553 Ciganos.

A fiabilidade dos resultados de estudos que procuram conhecer a sociodemografia ou outras caraterísticas das pessoas ciganas depende de alguns fatores, desenvolvem-se de seguida alguns deles.

\section{A cobertura territorial}

A diversificação da cobertura territorial é relevante quando se pretende ter um estudo exaustivo (para um estudo de caso não seria problemático). Uma vez que no caso português, são conhecidas diferenças territoriais relevantes (Mendes, Magano \& Candeias, 2016). Tendo em conta que para esta pequena análise apenas foram selecionados os estudos mais extensivos, todos eles assumem uma cobertura territorial considerável.

\section{A dimensão da amostra}

O segundo fator a ser enunciado é a dimensão da amostra que foi inquirida. E neste critério, também se pode considerar que os quatro estudos acima descritos foram exaustivos. Pese embora não seja uma opinião unânime, na literatura não existe um argumento consensual, ou razoável sobre a dimensão da amostra. Se por um lado, seria desejável cumprir critérios de aleatoriedade e representatividade. Por outro lado, não é possível estabelecer com rigor uma amostra, uma vez que as amostras são uma parte do universo e, como já foi argumentado, não é possível conhecer o universo. Nas palavras de Ivanov e colegas (2012) “" A sample of an undefined universe" is an oxymoron. Strictly speaking, one cannot define a sample not knowing exactly what is being sampled." (p.8). Obstante o argumento de que não é possível definir tal universo, há que referir a existência de fórmulas que desenvolvidas para o cálculo de amostras

\footnotetext{
${ }^{8}$ Projeto REHURB - Realojamento e Regeneração Urbana que decorreu no CEG-IGOT no ano de 2010.
} 
em que não é conhecido o universo, como a fórmula de Cochran (1977), que podem ser aplicadas a qualquer tipo de universo.

\section{Limitações associadas a amostras não probabilísticas}

Mais importante do que uma discussão entre representatividade versus não representatividade da amostra, é de frisar que existem, normalmente, problemas associados à amostragem. Por outras palavras, nos estudos que foram consultados para esta pequena reflexão, a escolha dos inquiridos é sempre enviesada. Nos casos em que o desenho da amostra foi baseado nos estudos anteriores, a amostra tenderá a incidir num perfil específico. Se a amostra incidir sobre a população que está sinalizada pela GNR, pela Segurança Social ou por departamentos de habitação social estará a ser focado um perfil muito específico. A limitação associada é que oculta determinados segmentos da população cigana menos visíveis, como que um grupo oculto. Isto porque as amostras tendem a ser desenhadas tendo como base populações desfavorecidas. Um exemplo, no estudo da FRA (2017b), que enfatizou Ciganos a viverem em zonas de elevada concentração, deixou de parte, tecnicamente, Ciganos que não são benificiários de apoios sociais e Ciganos que não vivem em zonas de elevada concentração. De acordo com a teoria do efeito de bairro (neighborhood effect no original) o contexto de bairro (ou simplesmente da área de residência) impacta nas caraterísticas dos seus residentes em diversas dimensões. Por vezes, independentemente dos seus atributos de nível individual (Roux, 2001). Esta corrente de estudos, especialmente desenvolvida nos Estados Unidos, foca-se nas consequências negativas de viver em zonas desprivilegiadas. Por vezes, pode até não importar tanto as caraterísticas do bairro em si, mas a reputação percebida do bairro (Kintrea \& Atkinson, 2001). São vários os mecanismos através do qual o bairro impacta nos seus residentes: a existência de role models, os grupos de pares (Durlauf, 2004); por mecanismos, epidémicos, institucionais, de competição por recursos escasso, de espectativas, de discriminação, de insegurança ou de barreiras físicas (Roux, 2001). As teorias dos efeitos de bairro foram desenvolvidas em diversas áreas académicas, seja na saúde pública (Braveman, Cubbin, Egerter, \& Pedregon, 2011; Roux, 2001), no acesso ao mercado de trabalho (Durlauf, 2004; Wilson, 1987, 1996), ou na participação política (Barber \& Imai, 2014; Huckfeldt, 1979). Estas dimensões, em que foi argumentado e testado o efeito de bairro são, coincidentemente, dimensões de análise comuns nos processos de inquirição a Ciganos. O que se argumenta é que, ao incidir a inquirição em zonas de elevada concentração de Ciganos, está a focar-se na fração mais fragilizada desta população. Não se ignora que esta seja a aquela com maior necessidade de intervenção, contudo, existe um segmento, 
que pode encontrar numa posição de menor desvantagem ou até mesmo numa posição vantajosa, que também é importante conhecer. Mas se em todas estas dimensões, a população que vive concentrada é mais desprivilegiada, existe uma dimensão em que se argumenta que a situação pode seguir o sentido contrário: na percepção de discriminação. A ideia é desenvolvida no próximo parágrafo.

O último estudo que foi descrito nesta secção, levado a cabo pela FRA (2017a), focava-se na percepção de discriminação e, por opção metodológica, incidia em zonas de elevada concentração de Ciganos. Segundo alguma da teoria sobre a percepção de discriminação, residir em zonas de elevada concentração coétnica implica que o contacto com a população maioritária seja menos frequente. Nesse sentido, as probabilidades de se darem situações de discriminação serão menores. Por exemplo, um estudo sobre a percepção de discriminação em imigrantes de um concelho da Área Metropolitana de Lisboa, verificou que a percepção de discriminação era bastante inferior em imigrantes que não residiam em habitação social (Mendes \& Candeias, 2013). Estudos nos Estados Unidos sobre populações afro-americanas mostram que, por um lado, em bairros com elevada proporção de coétnicos, o peso de pessoas que relatam terem sido vítimas de discriminação é menor. Por outro lado, pessoas que residam em bairro predominantemente brancos, tendem a perceber com mais intensidade a sua posição inferior em termos de status social, e a sua percepção de discriminação é superior (Dailey, Kasl, Holford, Lewis, \& Jones, 2010). Refere-se ainda que, segundo Kriegel e colegas (1998) pessoas que se encontram numa posição socioeconómica desfavorável e que são sujeitas a diversas formas de exclusão e privação podem, por vezes, resignar-se à sua condição, interiorizando e/ou naturalizando este estatuto, desvalorizando situações concretas de discriminação. Tendo em conta o que tem sido desenvolvido nesta corrente, é plausível considerar que, ao inquirir pessoas ciganas que residem em zonas de elevada concentração coétnica, pode-se estar a deixar de parte os Ciganos cuja percepção de discriminação será superior. Por outras palavras, o fenómeno pode estar a ser subestimado.

\section{Terceira questão. Quais as atitudes da população não-cigana face aos ciganos?}

Esta questão é importante para perceber a integração dos Ciganos. Para perceber o racional subjacente a esta questão cita-se o modelo heurístico de integração de Penninx (2013) (Figura 2,). Este modelo foi desenvolvido para estudar a integração de imigrantes, mas é suficientemente abrangente para cobrir também a população cigana. A ideia importante para o caso das pessoas ciganas é que, para estudar a integração devem ser analisadas duas partes: a população minoritária e a população maioritária. Para esta reflexão, será frisada a parte da população de 
acolhimento ou população maioritária (os não-Ciganos). E é aqui que vão ser analisados valores, atitudes e práticas em relação aos Ciganos, que influenciam na integração dos mesmos.

Figura 2. Modelo heurístico de integração de Penninx

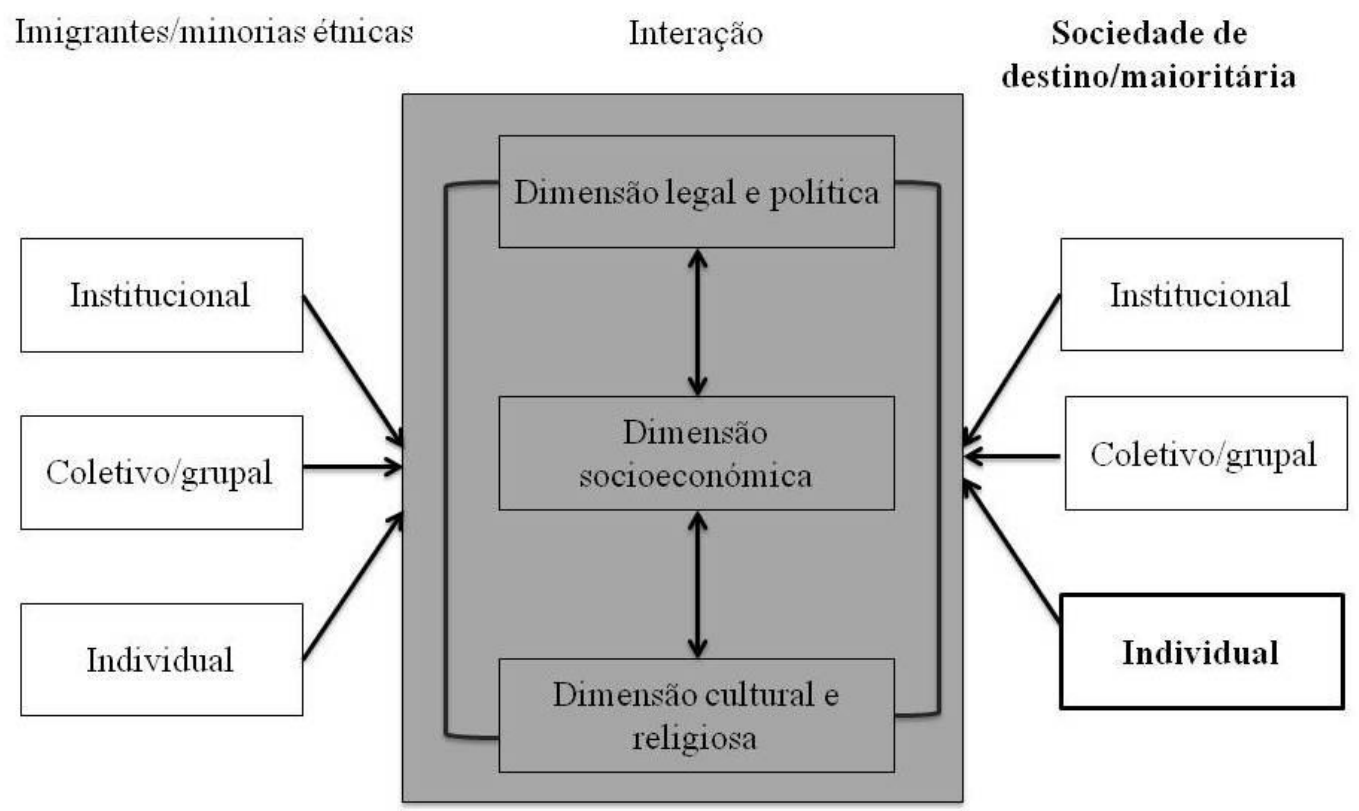

Fonte: Penninx (2013)

\section{Os estudos de valores e opinião pública}

Uma das formas de analisar as posições da população não-Cigana é através de grandes inquéritos aos valores, atitudes e opinião pública (Eurobarómetro, European Value Survey, European Social Survey, etc.). Estes estudos cobrem uma diversidade de temas. Embora foquem em especial componente política, existem também algumas questões dedicadas às atitudes face a grupos minoritários. Para ilustrar este exemplo foi efectuado um levantamento não exaustivo, que alguns dados referentes a atitudes face a Ciganos em algumas vagas do Eurobarómetro. O objetivo não é o de analisar os dados, mas sim mostrar a quantidade de material que existe disponível. Na Tabela 2. são apresentados alguns dados sobre atitudes opiniões e práticas dos portugueses em relação a Ciganos. Entre outras questões estão disponíveis dados sobre o quanto é que as pessoas consideram que ser Cigano é uma vantagem ou uma desvantagem, a distância social em relação a pessoas ciganas, o contacto, através da existência de amigos Ciganos ou ainda a reação a ter Ciganos numa esfera próxima, como colega de trabalho ou genro/nora. 
Tabela 2. Opiniões, atitudes e práticas dos portugueses em relação a Ciganos

\begin{tabular}{|c|c|c|c|c|c|}
\hline \multicolumn{3}{|c|}{$\begin{array}{l}\text { Diria que o fato de pertencer aos seguintes grupos tende a } \\
\text { ser uma vantagem ou uma desvantagem, ou não, na socie- } \\
\text { dade portuguesa no momento atual? }\end{array}$} & \multicolumn{3}{|c|}{$\begin{array}{l}\text { Considera que os Ciganos são um grupo que se en- } \\
\text { contra em risco de discriminação }\end{array}$} \\
\hline & $\mathrm{n}$ & $\%$ & & $\mathrm{n}$ & $\%$ \\
\hline Tende a ser uma vantagem & 30 & 3,2 & Discorda totalmente & 206 & 22,1 \\
\hline Tende a ser uma desvantagem & 768 & 82,1 & Tende a discordar & 452 & 48,5 \\
\hline Nem vantagem nem desvantagem & 138 & 14,7 & Tende a concordar & 215 & 23,1 \\
\hline Total & 936 & 100,0 & Concorda completamente & 59 & 6,3 \\
\hline \multicolumn{3}{|c|}{ Fonte: Eurobarometer 65.4 (June-July 2006) } & Total & 932 & 100,0 \\
\hline \multicolumn{3}{|c|}{ Tem amigos ou conhecidos que são ciganos? } & \multicolumn{3}{|c|}{ Fonte: Eurobarometer 77.4 (June 2012) } \\
\hline & $\mathrm{n}$ & $\%$ & \multicolumn{3}{|c|}{$\begin{array}{l}\text { Como se sentiria se um filho/filha numa relação } \\
\text { amorosa com um cigano/cigana }\end{array}$} \\
\hline $\operatorname{Sim}$ & 229 & 23,3 & & $\mathrm{n}$ & $\%$ \\
\hline Não & 754 & 76,7 & 1 - Nada confortável & 186 & 22,5 \\
\hline Total & 983 & 100,0 & 2 & 56 & 6,8 \\
\hline \multicolumn{3}{|c|}{ Fonte: Eurobarometer 65.4 (June-July 2006) } & 3 & 58 & 7,0 \\
\hline \multicolumn{3}{|c|}{$\begin{array}{l}\text { O quanto confortável se sentiria por ter um Cigano como } \\
\text { vizinho }\end{array}$} & 4 & 62 & 7,5 \\
\hline & $\mathrm{n}$ & $\%$ & 5 & 91 & 11,0 \\
\hline Desconfortável & 190 & 19,2 & 6 & 86 & 10,4 \\
\hline Razoavelmente confortável & 321 & 32,4 & 7 & 73 & 8,8 \\
\hline Confortável & 235 & 23,7 & 8 & 63 & 7,6 \\
\hline Indiferente & 244 & 24,6 & 9 & 23 & 2,8 \\
\hline Total & 990 & 100,0 & 10 - Totalmente desconfortável & 128 & 15,5 \\
\hline \multicolumn{3}{|l|}{ Fonte: Eurobarometer 69.1 (2008) } & \multicolumn{3}{|c|}{ Fonte: Eurobarometer 83.4 (May-June 2015) } \\
\hline
\end{tabular}

Estes são estudos que obedecem a metodologias rigorosas de representatividade e aleatoriedade e por isso serão confiáveis. Em relação ao grupo-alvo destas questões é de frisar que o racismo face a Ciganos é muito generalizado e socialmente aceite, como refere McGarry (2017) "in many societies it is perfectly acceptable do denigrate Roma by involking so-called traits and characteristics that all Roma supposedly possess." (p.1), obstante medidas que têm vindo a ser implementadas de forma a sancionar discriminação contra Ciganos. Deste modo, é bem possível que estas respostas não sofram de um efeito de desejabilidade social. O enviesamento da desejabilidade social assenta na ideia que durante o processo de inquirição (como em muitas outras atividades sociais), as pessoas organizam o seu comportamento de acordo com o que consideram que os outros esperam ser apropriado nesse determinado tipo de interação. Mais 
especificamente, no contexto de inquirição, pessoas com pontuação mais elevada num indicador de desejabilidade social deram respostas menos preconceituosas (Phillips \& Clancy, 1972 p.936). Limitação que não deve ser muito relevante quando são indagadas as atitudes face a pessoas ciganas.

Os valores expressos na Tabela 2. servem apenas de exemplo. Para além destas medidas descritivas simples, cada um destes indicadores pode ser analisado a nível individual, a um nível meso, agregado, podem-se comparar as respostas de regiões do país, e a um nível mais macro, a nível internacional, podem ser feitas análises comparativas. Por exemplo: As atitudes diferem entre Portugal e Espanha? E entre a Península Ibérica e os Países de Leste?

Não obstante estas potencialidades existem limitações associadas. O que se pode ganhar com esta extensividade de dados, perde-se em detalhe ou em rigor da categoria. Uma vez que ao questionar-se a população maioritária sobre o que pensam sobre os Ciganos dá-se uma uniformização de uma categoria que se sabe ser heterogénea, seja em termos territoriais (Mendes et al., 2016), no perfil escolar (Candeias, 2016), ou em termos de inserção profissional (Magano, 2010). Acrescenta-se ainda que é desconhecido o estereótipo de Cigano que os participantes do Eurobarómetro têm presente quando respondem a este inquérito.

Um segundo exemplo de estudos sobre a população não-cigana é o que está a ser desenvolvido no âmbito do projeto EDUCIG (Desempenhos escolares entre os Ciganos: investigaçãoação e projeto de co-design). Não se trata de um estudo sobre a população em geral, mas incide em pessoas que podem ter um papel determinante na integração de pessoas ciganas: professores e técnicos de emprego. O projeto em causa contempla um inquérito por questionário a membros destas duas categorias profissionais e foca nas percepções que têm sobre o acesso de pessoas ciganas ao mercado de trabalho e ao ensino superior. De seguida é apresentado o sustentamento teórico para esta ilustração.

Numa forma sumária, a teoria sistémica ${ }^{9}$ assenta na ideia que a sociedade é constituída por diversos sistemas. Os sistemas são constituídos por uma black box ou caixa negra (porque não permite conhecer o processo que decorre no seu interior) e gatekeepers (que condicionam o acesso ao sistema). O sistema está inserido num ambiente onde se dá a entrada inputs e saída de outputs, sinais entre o ambiente e o sistema. Adaptado de forma simplista ao sistema escolar e aos centros de emprego: os alunos e os inscritos nos centros de emprego são o input e o output. O sistema escolar contempla, dentro da caixa negra, os professores. $\mathrm{O}$ modo como os alunos

\footnotetext{
${ }^{9}$ A teoria sistémica foi aplicada às Ciências Sociais conhece como fortes impulsionadores Parsons (1951) e Luhmann (1995) numa abordagem mais geral, e teve aplicações a diversas áreas de investigação (política, educação, media, organizações).
} 
saem e para que sistema são redirecionados posteriormente ao primeiro processo depende, em parte, dos professores. Ou seja, estarão posicionados na black box. Por vezes a entrada dentro do sistema está condicionada por gatekeepers. No caso dos centros de emprego, a figura dos técnicos de emprego pode ser interpretada como um gatekeeper uma vez que estes podem facilitar ou dificultar o acesso ao sistema de emprego.

Estes dois exemplos da abordagem seguida no projeto EDUCIG ilustram a possibilidade de melhor conhecer como se dá a integração de pessoas ciganas em áreas específicas, auscultando a população não-cigana.

\section{Considerações finais}

Estudar pessoas ciganas através de metodologias quantitativas é uma área de estudo bastante interessante e com diversas possibilidades de desenvolvimento. Pode também ser uma tarefa ingrata, lidar com a escassez de prazos, dos orçamentos e da adesão por parte dos participantes. (nesta, como em qualquer outra área). Estes estudos têm algumas limitações associadas, que devem ser tidos em conta quando são lidos.

A quantificação de quantas pessoas ciganas existem em determinado país é sempre uma tarefa de difícil aferição. Em Portugal, até à data, tem-se recorrido ao método indireto, frequentemente com uma conjugação de diversas fontes. A ocultação de segmentos menos excluídos em termos de proteção social leva a que os valores calculados o sejam por defeito. O modo de contabilizar Ciganos não excluídos ainda se encontra por desenvolver. Conhecer as caraterísticas de Ciganos portugueses com base em inquéritos por questionário assenta em amostras enviesadas. Levantamentos mais exaustivos e não tão focados em beneficiários de serviços sociais poderá melhorar o rigor com que é feita a aferição dos seus perfis e condições de vida. No lado da população maioritária têm sido conduzida estudos de opinião e valores que permitem perceber como os portugueses pensam e agem em relação aos seus conacionais ciganos. Estes dados não têm tido o devido interesse e constituem uma fonte de informação por explorar. Mas não é só da auscultação da população em geral que se pode obter pistas de como se dá a integração das pessoas ciganas. Os inquéritos a técnicos de emprego e a professores realizados no âmbito do projeto EDUCIG permitirão conhecer como pensam profissionais que se encontram em posições influentes para a integração dos Ciganos. 


\section{Bibliografia}

ACIDI/GACI. (2013). Estratégia Nacional Para a Integração das Comunidades Ciganas 2013 - 2020. Lisboa: ACIDI/GACI.

Ahmed, P., Feliciano, C., \& Emigh, R. J. (2007). Internal and External Ethnic Assessments in Eastern Europe. Social Forces, 86(1), 231-256.

Barber, M., \& Imai, K. (2014). Estimating Neighborhood Effects on Turnout from Geocoded Voter Registration Records. IMAI Working Paper.

Braveman, P., Cubbin, C., Egerter, S., \& Pedregon, V. (2011). Neighborhoods and Health. Robert Wood Johnson Foundation Issue Brief(8).

Cahn, C., \& Guild, E. (2010). Recent Migration of Roma in Europe. OSCE High Commissioner on National Minorities/Council of Europe Commissioner for Human Rights.

Candeias, P. (2016). "No estudar é que está o ganho?" Comparação entre ciganos com diferentes níveis de escolaridade com base em dados do Estudo Nacional sobre as Comunidades Ciganas. Revista de Sociologia Configurações(18).

Castro, A. (2004). Ciganos e ltinerância. Realidades Concelhias e Formas de Hospitalidade. Cidades - Comunidades e Territórios(9), 55-69.

Castro, A. (2016). Na luta pelos bons lugares. Ciganos, visibilidade sociale controvérsias espaciais. Lisboa: ACM.

Cochran, W. G. (1977). Sampling Techniques. 3rd Edition. New York: John Wiley \& Sons.

Dailey, A. B., Kasl, S. V., Holford, T. R., Lewis, T. T., \& Jones, B. A. (2010). Neighborhoodand individual-level socioeconomic variation in perceptions of racial discrimination. Ethn Health, 15(2), 145-163. doi: doi:10.1080/13557851003592561

DGEEC. (2017). Perfil Escolar da Comunidade Cigana 2016/17. Direção-Geral de Estatísticas da Educação e Ciência.

Durlauf, S. N. (2004). Neighborhood Effects. Handbook of Regional and Urban Economics, 4, 2173-2242. doi: 10.1016/S0169-7218(04)07050-9

Fleck, G., \& Rughiniş, C. (2008). Come Closer. Inclusion and Exclusion of Roma in PresentDay Romanian Society. Bucharest: Human Dynamics.

FRA. (2013). Roma Pilot Survey Technical Report: Methodology, sampling and fieldwork. Luxembourg: European Union Agency for Fundamental Rights.

FRA. (2017a). Second European Union Minorities and Discrimination Survey. Main results. Luxembourg: European Union Agency for Fundamental Rights.

FRA. (2017b). Second European Union Minorities and Discrimination Survey. Technical report. Luxembourg: European Union Agency for Fundamental Rights.

Huckfeldt, R. R. (1979). Political Participation and the Neighborhood Social Context. American Journal of Political Science, 23(3), 579-592. 
IHRU. (2015). Caracterização das Condições de Habitação das Comunidades Ciganas Residentes em Portugal. Instituto da Habitação e da Reabilitação Urbana, I.P.

Ivanov, A., Kling, J., \& Kagin, J. (2012). Integrated household surveys among Roma populations: one possible approach to sampling used in the UNDPWorld Bank-EC Regional Roma Survey 2011. Roma Inclusion Working Papers. Bratislava: United Nations Development Programme.

Kertesi, G., \& Kézdi, G. (2011). Roma employment in Hungary after the post-communist transition. Economics of Transition, 19(3), 563-610.

Kintrea, K., \& Atkinson, R. (2001). Disentangling Area Effects: Evidence from Deprived and Non-deprived Neighbourhoods Urban Studies, 38(12), 2277-2298. doi: https://doi.org/10.1080/00420980120087162

Kriegel, N., Sidney, S., \& Coaklev, E. (1998). Racial Discrimination and Skin Color in the CARDIA Study: Implications for Public Health Research. American Journal of Public Health, 88(9), 1308-1313.

Ladányi, J., \& Szelényi, I. (2001). The Social Construction of Roma Ethnicity in Bulgaria, Romania and Hungary During Market Transition. Review of Sociology, 7(2), 79-89.

Luhmann, N. (1995). Social Systems. Stanford: Stanford University Press.

Magano, O. (2010). "Tracejar vidas normais" Estudo qualitativo sobre a integração social de indivíduos de origem cigana na sociedade portuguesa. Tese de Doutoramento em Sociologia. Especialidade Relações Interculturais, Universidade Aberta.

McGarry, A. (2017). Romaphobia. The last acceptable form of racism. London: Zed Books.

Mendes, M., Magano, O., \& Candeias, P. (2014). Estudo Nacional Sobre as Comunidades Ciganas. Lisboa: ACM.

Mendes, M., Magano, O., \& Candeias, P. (2016). Social and Spatial Continuities and Differentiations among Portuguese Ciganos: Regional Profiles. Studia UBB Sociologia(61), 5-36.

Mendes, M. M., \& Candeias, P. (2013). Immigrant perceptions of ethnic and racial discrimination: patterns and singularities in a municipality in the Lisbon Metropolitan Area. International Review of Sociology, 23(2), 401-420.

Moutouh, H. (2000). Les Tsiganes: Dominos. Flammarion.

Nunes, O. (1996). O Povo Cigano. Porto: Livraria Apostolado da Imprensa.

Parsons, T. (1951). The Social System, nova edição de 1991: Routledge.

Penninx, R. (2013). Research on Migration and Integration in Europe. Achievements and Lessons. Amsterdam: University of Amsterdam.

Phillips, D. L., \& Clancy, K. J. (1972). Some Effects of "Social Desirability" in Survey Studies. American Journal of Sociology, 77(5), 921-940.

REAPN. (2009). As comunidades ciganas e a saúde: um primeiro retrato nacional. Madrid: Rede Europeia Anti-Pobreza/Fundación Secretariado Gitano. 
Roux, A. V. D. (2001). Investigating Neighborhood and Area Effects on Health. American Journal of Public Health, 91(11), 1783-1789.

SOSRacismo. (2001). Sastipen ta li saúde e liberdade. Ciganos, números, abordagens e realidades. Lisboa: SOS Racismo.

Wilson, W. J. (1987). The Truly Disadvantaged. The Inner City, the Underclass, and Public Policy. Chicago/London: The University of Chicago Press.

Wilson, W. J. (1996). When Work Disappears: The World of the New Urban Poor. New York: Vintage Books.

Outras fontes

Special Eurobarometer 263 / Wave 65.4 - TNS Opinion \& Social 2006/2007

Special Eurobarometer 296 / Wave 69.1 - TNS opinion \& social 2008

Special Eurobarometer 317 / Wave 71.2. - TNS Opinion \& Social 2009

Special Eurobarometer 393 / Wave EB77.4 - TNS Opinion \& Social 2012

Special Eurobarometer 4372015 


\title{
Capítulo 3. \\ Desafios Metodológicos na pesquisa sobre ciganos: cenários, desenhos de pesquisa e questões metodológicas \\ no contexto brasileiro
}

\author{
IGOR SHIMURA ${ }^{1}$ \\ Mestre em Ciências Sociais pela Universidade Estadual de Maringá (UEM). \\ Conferencista, pesquisador e professor em cursos de graduação e especialização. Ativista social pela Associação \\ Social de Apoio Integral aos Ciganos (ASAIC) \\ dromlachom@gmail.com
}

Resumo: Reconhecendo os desafios da pesquisa social com ciganos em relação ao acesso, modelos, cenários e questões metodológicas, o presente artigo trata de caminhos de investigação que incluam os interlocutores como coautores das produções que tratam sobre suas realidades. É imprescindível que se considere a sensibilidade que esse tipo de pesquisa envolve, haja vista a história e as experiências acumuladas de uma minoria étnica que sofreu grandes perseguições ao longo dos séculos em diferentes contextos socioculturais. Essa reflexão precisa se fazer presente entre os pesquisadores, de maneira que seus trabalhos se prestem a dar ouvidos e voz aos seus interlocutores, favorecendo e aperfeiçoando o avanço dos estudos ciganos.

Palavras-chave: pesquisa; pesquisadores; ciganos brasileiros.

\begin{abstract}
Recognizing the challenges of social research among the Roma people in relation to access, models, scenarios and methodological issues, this article deals with research paths where interlocutors are included as co-authors of academic productions that deal with their realities. It is essential to consider the sensitivity that this type of research involves, considering the history and accumulated experiences of an ethnic minority that has suffered great persecution through the centuries in different sociocultural contexts. This reflection needs to be present

\footnotetext{
${ }^{1}$ Igor Shimura é Mestre em Ciências Sociais pela Universidade Estadual de Maringá (UEM) com dissertação intitulada "Ser cigano: identidade étnica em um acampamento Calon itinerante". Pós-graduado em nível de Especialização em Antropologia Cultural pela Pontifícia Universidade Católica do Paraná (PUCPR). Graduado em Teologia pela Faculdade Teológica Sul Americana (FTSA). É filiado ao Gypsy Lore Society (GLS) e membro colaborador da Associação Brasileira de Antropologia (ABA). Atuou como diretor do Departamento de Igualdade Racial e Étnica (DEPIR) da Secretaria Nacional de Políticas de Promoção da Igualdade Racial (SNPIR) do Ministério da Mulher, Família e Direitos Humanos (MMFDH). Conferencista e professor em cursos de graduação e especialização. Ativista social pela Associação Social de Apoio Integral aos Ciganos (ASAIC). Currículo lattes: http://lattes.cnpq.br/7185041613714846
} 
among researchers, so that in doing their research they will listen and give voice to the interlocutor, favoring and improving the advance of Roma studies.

Keywords: research; researchers; Roma.

Ao longo da vida presenciei e viabilizei muitos encontros entre ciganos e pesquisadores. Pude colaborar e participar de projetos acadêmicos, sociais e jornalísticos em diferentes comunidades ciganas brasileiras. Dentre os ciganos existem tanto aqueles que consideram as pesquisas importantes como também os que enxergam pesquisadores como meros especuladores e intrusos dispostos a piorar sua "imagem" diante da sociedade ampla. Lembro-me de um episódio marcante, ocorrido há cerca de quinze anos. Enquanto eu conversava com um amigo cigano, D.S., em seu acampamento, no município de Araucária, no estado do Paraná, fomos interrompidos por um jovem desconhecido que, parando na entrada da tenda, pediu para "conversar um pouco". D.S. o convidou para se aproximar, se apresentar melhor e explicar o que exatamente estava buscando. Tratava-se de um estudante que recebera a tarefa de fazer uma "pesquisa sobre ciganos" e apresentá-la aos seus colegas no dia seguinte. Concordando em ajudá-lo D.S. começou a responder a algumas de suas inquietantes perguntas.

As duas primeiras perguntas foram suficientes para deixar meu amigo visivelmente irritado. "Porque os ciganos não se esforçam para se adaptar à nossa sociedade?”, “por que todo cigano é trapaceiro?", iniciou desastrosamente o inexperiente estudante. Tais perguntas faziam referência a estereótipos e generalizações reproduzidas amplamente na mídia, arte e literatura, e sempre despertaram a indignação dos povos ciganos ${ }^{2}$.

Perplexo e irritado, D.S. se sentiu ofendido e respondeu de forma ríspida. Apesar disso permitiu que a "entrevista" prosseguisse, no entanto, as perguntas seguintes nos faziam pensar que se tratava de uma pesquisa num zoológico: “o que vocês ciganos comem?”, "como vocês dormem?", “como se reproduzem?" etc. Por fim meu amigo, profundamente irritado, expulsou o jovem estudante e ordenou que "nunca mais pisasse ali". Concordei com ele, mas fiquei preocupado com o tipo de informação que seria apresentada na escola do rapaz no dia seguinte! Um desastre!

\footnotetext{
${ }^{2}$ No contexto brasileiro, tanto na linguagem política como entre as comunidades, há uma preferência pelo termo uso do etnônimo "cigano" em detrimento de "Roma". A razão disso reside no fato de que os grupos mais numerosos são os Calon e os Rom, sendo que os Rom são em menor número e utilizam "Roma" para designar a si mesmos, ao passo que os Calon usam o termo "Calen" ou "Suêti". O termo "Roma" não é aceito pelos Calon para lhes fazer referência e por essa razão a palavra "cigano", como termo étnico neutro, se refere tanto aos Rom como aos Calon.
} 
Esse episódio, contado de forma resumida, ilustra o desafio metodológico que envolve a pesquisa com ciganos. Uma abordagem equivocada, construída sob perspectivas preconceituosas, desprovida de plataformas que permitam uma maior aproximação e convivência com uma comunidade ou indivíduo, ou ainda sem nenhuma sensibilidade em relação às diferentes realidades socioculturais, pode gerar obstáculos imensos para a pesquisa com ciganos. Ao fechar portas para si mesmo, o jovem estudante possivelmente fechou portas para outros estudantes e pesquisadores, pelo menos naquela comunidade em Araucária.

Não podemos mensurar com precisão os efeitos e desdobramentos desse episódio, mas certamente foram desastrosos, aprofundando o distanciamento entre ciganos e pesquisadores não ciganos. Não tenho dúvida de que o ocorrido foi divulgado por D.S. aos seus parentes e comunidade, que por sua vez podem ter espalhado a história a outras comunidades, quem sabe alertando os grupos para a "intransigência" de estudantes que se aproximam para "especular" sobre a "vida de cigano", com ofensas e indiretas!

Diante disso concluo que pesquisar ciganos sem o devido preparo é um desserviço à academia, à sociedade e principalmente aos próprios ciganos, já que os resultados de boas pesquisas podem se refletir no combate ao preconceito e consequentemente ao quadro de violações de direitos humanos sofridos por ciganos cotidianamente.

Tenho lembranças de outros fatos semelhantes, em diferentes comunidades, envolvendo não somente pesquisadores, mas também repórteres e agentes do poder público. Conheço inúmeros ciganos que, acreditando estarem contribuindo com a desconstrução de estereótipos a seu respeito, concederam entrevistas e responderam a questionários de bom grado, mas ao terem acesso às produções finais, acadêmicas ou jornalísticas, de seus entrevistadores experimentaram uma grande frustração, pois percebem a difusão de inverdades e distorções ao seu respeito, de forma que a "imagem cigana" fica ainda mais maculada perante a sociedade envolvente.

\section{Ciganos? Por que pesquisá-los?}

Essa é uma pergunta recorrente que chega aos ouvidos de diferentes pesquisadores por parte de seus colegas, amigos e familiares. Algumas vezes essa pergunta é feita pelos próprios ciganos, especialmente por aqueles que pertencem a grupos mais fechados e não acreditam - ou não entendem - nas motivações dos pesquisadores. Essa pergunta precisa ser respondida com franqueza e seriedade!

A meu ver a resposta à essa difícil pergunta está ligada ao que Frans Moonen (2010: 10) tratou em seu artigo, Os estudos ciganos no Brasil: 1885-2010, onde questiona: 
Resta ainda a pergunta: qual foi a contribuição prática destes estudos para a solução da problemática cigana, para diminuir ou acabar com a discriminação ou marginalização dos ciganos pela sociedade brasileira, para melhorar suas condições de vida, para defender seus diretos como cidadãos brasileiros? Algum desses estudos acadêmicos contribui para diminuir a ignorância dos brasileiros sobre seus conterrâneos ciganos? Ou contribui para o medo e os preconceitos que muitos brasileiros costumam ter dos ciganos?

Minha mãe sempre dizia: "se não for para ajudar, então não atrapalhe!”. Moreira Neto (1959: 49-64) afirmou que o conhecimento obtido pelo pesquisador "traz em si implícita certa responsabilidade com respeito ao destino das populações que estuda". Falando a antropólogos, propunha que, ao elaborar dados de interesse científico, dever-se-ia também discutir "as ameaças que se antepõem ao destino dos povos que estuda" (Idem). Dessa forma, o que se sinaliza é que nossas pesquisas precisam ser planejadas de forma a contribuir com a solução de seus problemas.

Como membro colaborador da Associação Brasileira de Antropologia (ABA) menciono aqui nosso código de ética ${ }^{3}$ que, ao tratar dos direitos das populações que são objeto de pesquisa, reza a "garantia de que a colaboração prestada à investigação não seja utilizada com o intuito de prejudicar o grupo investigado". Ora, se a pesquisa não deve ser utilizada "com intuito de prejuízo", fica claro o seu propósito benéfico, que passa pela melhoria de vida, bemestar e solução de problemas das populações pesquisadas. Essa perspectiva deve se estabelecer nos parâmetros motivadores de qualquer pesquisador, para que não se cometam os mesmos erros do passado em relação à propagação de imagens preconceituosas contra ciganos, conforme veremos mais adiante.

A discriminação racial ou étnico-racial é definida pela Lei n. 12.288, de 20 de julho de 2010, o Estatuto da Igualdade Racial (BRASIL, 2010), como

Toda distinção, exclusão, restrição ou preferência baseada em raça, cor, descendência ou origem nacional ou étnica que tenha por objeto anular ou restringir o reconhecimento, gozo ou exercício, em igualdade de condições, de direitos humanos e liberdades fundamentais nos campos político, econômico, social, cultural ou em qualquer outro campo da vida pública ou privada.

Essas atitudes, uma vez voltadas para ciganos, podem ser entendidas como "ciganofobia" ou "anticiganismo". O historiador Wolfgang Wippermann (apud Piasere, 2018: 14) propõe o conceito de anticiganismo como "qualquer forma de comportamento contra ciganos". Esse fenômeno está relacionado ao etnocentrismo, que é uma visão de mundo com a qual tomamos

\footnotetext{
${ }^{3}$ ABA. Código de ética do antropólogo e da antropóloga. http://www.portal.abant.org.br/codigo-de-etica/ Acessado em 10 nov. 2019.
} 
nosso próprio grupo como centro de tudo, como se nossa forma de viver fosse superior, melhor (Cf. Rocha, 2006: 7). Sendo assim uma pessoa ciganofóbica tem sua própria perspectiva cultural, associada às imagens estereotipadas que se fazem de ciganos, como fundamento para repudiar a ciganidade.

Se um pesquisador vai a campo com espírito etnocêntrico e ciganofóbico certamente desenvolverá uma produção desastrosa, carregada de preconceitos e elementos anticiganos, criticando comportamentos, cultura e valores de seus interlocutores. Vimos isso na história e não queremos que se repita, mas o anticiganismo ainda é praticado e precisa ser denunciado, inibido e punido. Para citar dois exemplos de como pesquisas anticiganas se desdobram de formas extremamente desastrosas cito Heinrich Grellmann (1753-1804) e George Borrow (18031881), famosos entre os chamados "ciganólogos". Grellmann ficou famoso com seu livro Os Ciganos... na Europa, que foi traduzido em vários idiomas. Sua pesquisa contou principalmente com fontes secundárias, a saber, uma série de pequenos artigos, sendo raro seu contato com ciganos.

Moonen (2000a: 65) diz que Grellmann "costumava citar fontes jornalísticas sensacionalistas", pelo que, tomando uma notícia de jornais de 1782, publicou uma acusação de que ciganos seriam antropófagos. " $\mathrm{Na}$ época, 84 ciganos foram presos como suspeitos de terem assassinado e comido algumas pessoas desaparecidas: 41 ciganos foram decapitados, enforcados ou esquartejados" (Ibid.: 66). Ainda diz mais (Ibid.: 67):

Desnecessário dizer que Grellmann não realizou nenhuma pesquisa entre os ciganos para saber se tudo isto era verdade ou apenas fantasia ou invenção. Nem tampouco perguntou aos ciganos porque, eventualmente, eles agiam desta ou daquela maneira, numa tentativa de entender melhor o seu comportamento e sua personalidade. Numa atitude pouco científica, Grellmann apenas reproduziu os estereótipos que em sua época existiam sobre os ciganos.

Quanto ao escritor inglês George Borrow, suas "pesquisas" apresentaram uma imagem altamente negativa e estereotipada de ciganos - principalmente dos espanhóis - em seu livro The Zincali. Ele afirmou que os ciganos chegaram à Espanha "com uma predisposição para qualquer espécie de crime e vilania" (Borrow apud Moonen, 2000a: 68) e que se tratava de uma população "repugnante", o mais "vil, degenerado e miserável povo na terra" (Idem).

Essas "pesquisas" provocaram incontáveis sofrimentos e desserviços à academia, à sociedade e obviamente diretamente aos ciganos pesquisados e indiretamente a outros. O reflexo da ciganofobia dos referidos escritores refletiu-se em diferentes contextos, já que suas produções se tornaram referências acadêmicas. No Brasil, por exemplo, no ano de 1710, os ciganos foram 
vítimas de violenta perseguição. Percebendo que se tratava de um grupo homogêneo, comunitário, com idioma e costumes comuns, autoridades os enxergaram como potenciais ameaças à ordem social.

O decreto de 11 de abril de 1718 é um exemplo claro desse preconceito anticigano, já que chamava o policiamento de ciganos, proibindo-os de usar seu idioma, numa clara tentativa de extermínio cultural e identitário: "foram degradados os ciganos do reino para a praça da cidade da Bahia, ordenando-se ao governador que ponha cobro e cuidado na proibição do uso de sua língua e gíria, não permitindo que se ensine a seus filhos, a fim de obter-se a sua extinção" (China, 1936: 62). Há ainda muitos outros documentos que atestam essas perseguições arbitrárias, tais como o das "provisões de 15 de Abril de 1718, 23 de agosto de 1724, 29 de Maio de 1726 e de 29 de Julho de 1740", onde se lê: "Se os ciganos e outros malfeitores, degredados do reino para Pernambuco, não adoptarem nesta capital algum modo de vida e continuarem a commetter crimes, serão novamente degredados para Angola" (Idem).

Para evitar horrores como esses e quaisquer outras formas de prejuízo aos ciganos pesquisados, a investigação deve buscar a compreensão "por dentro" (alteridade) e "por fora", bem como as relações sociais e suas implicações interétnicas, considerando as tensões constitutivas da prática investigativa, desprovida o quanto possível de uma perspectiva etnocêntrica. Vejamos o que diz Laplantine (2007: 183-184):

O primeiro tempo é o da aprendizagem através de um convívio assíduo e de uma verdadeira impregnação por seu objeto. Trata-se de interpretar a sociedade estudada utilizando os modos de pensamento dessa sociedade, deixando-se, por assim dizer, naturalizar por ela.

Diante desses e outros fatos semelhantes de propagação de estigmas e prejuízo orquestrados contra a imagem dos povos ciganos, por que então pesquisá-los? Justamente para desconstruir rótulos. Eis aí que uma grande razão: combater estereótipos! Como diz Barth (2011: 217), aí estão os párias, "rejeitados de forma ativa pela população hospedeira, em razão do comportamento ou de certas características inegavelmente condenadas". Reconhecer isso pode nos ajudar a pensar num senso de missão, objetivando derrubar "muros de preconceitos", utilizandose de conhecimento, e conhecimento esse produzido por alguém capaz de fazer a ponte entre estruturas e realidades, minimizando sofrimentos.

Sendo assim, pesquisar ciganos pode contribuir em muito com análises socioculturais da composição étnica de um determinado ajuntamento e organização nacional ou regional com vistas aos desdobramentos sociais, onde se oferecem importantes subsídios para a elaboração de políticas públicas adequadas às suas reais necessidades. E por se tratar de uma população que, via de regra, se encontra em vulnerabilidade social - não só no Brasil, mas em diferentes 
contextos - o pesquisador há de perceber as inúmeras mazelas sociais a que estão submetidas, de forma que as diferentes pesquisas realizadas podem revelar especificidades desconhecidas pelo poder público, através de descrições de sua cultura, experiências, regras de conduta, costumes etc.

Poderíamos citar diferentes exemplos de como as pesquisas podem contribuir para boas práticas sociais e elaboração e aplicação de leis em favor de ciganos. Um dos exemplos é a pesquisa realizada pelo antropólogo Frans Moonen (1944-2013), no início da década de 1990, entre os ciganos da cidade de Sousa, na Paraíba. Sua pesquisa foi encomendada pelo então Procurador da República da Paraíba, Luciano Mariz Maia, "visando a obtenção de dados para o Inquérito Civil instaurado, a pedido dos próprios ciganos, para apurar violações aos seus direitos e interesses" (Moonen, 2000b: 1). Na época Moonen identificou uma população de cerca de 800 pessoas de etnia Calon, sedentarizadas, em situação de extrema vulnerabilidade social, com baixa renda e excluídos da cidade.

A referida comunidade viveu de forma nômade até o início da década de 1960, quando recebeu apoio de um jovem prefeito chamado Antônio Mariz, que os acolheu e viabilizou sua permanência na cidade, pelo que alguns construíram pequenas casas numa área de periferia. Moonen relata ter a "notícia de que pessoas bem-intencionadas estariam planejando a construção de casas para ciganos", mas faz uma crítica: "não consta que estes 'planejadores' das casas ciganas tenham realizado pesquisas a respeito dos problemas, conflitos e valores culturais ciganos, nem sobre o tipo de casa desejada e mais apropriada para os ciganos" (Ibid.: 12). As pesquisas de Moonen inspiraram e encorajaram muitos outros a também investirem recursos e foco acadêmico na comunidade de Sousa, pelo que atualmente é a comunidade mais conhecida no universo acadêmico brasileiro, com diversas produções, principalmente etnográficas ${ }^{4}$.

Outro exemplo de pesquisa que pode contribuir com um olhar mais profundo sobre os ciganos é a do sociolinguista Fábio Dantas de Melo que investigou o idioma $c h i b i^{5}$ na comunidade Calon de Mambaí, Goiás. Conforme relata, já no início de sua produção, seu trabalho foi o de

\footnotetext{
${ }^{4}$ A Comunidade de Sousa tem servido de campo para pesquisas etnográficas de grande relevância no universo dos estudos ciganos brasileiros, de onde podemos citar alguns exemplos de produção, dentre artigos, livros, dissertações e teses acadêmicas: "O tempo de atrás": um estudo da construção da identidade cigana em Sousa-PB (2004) e Memória e etnicidade entre os ciganos Calon em Sousa-PB (2013), de Maria Patrícia Lopes Goldfarb, Os Calon do município de Sousa/PB: dinâmicas e transformações culturais, de Robson de Araújo Siqueira (2013), "Olhe nosso centro! Aqui somos todos ciganos": construções identitárias e dinâmicas políticas entre os ciganos de Sousa-PB, de Jamilly Rodrigues da Cunha (2015), "Em busca de uma sombra": a construção de uma territorialização através de processos de mobilidade e reconhecimento étnico entre os Ciganos de Sousa/PB, de Jéssica Cunha de Medeiros (2016), dentre outros.
}

\footnotetext{
5 Termo que designa a palavra "idioma” ou "língua” para o povo Calon no Brasil.
} 
“descrever em que grau o dialeto dos Calon do norte-nordeste de Goiás se deteriorou, investigando, no plano teórico, o seu caráter de língua obsolescente, e, em virtude disto, o processo de morte em que se encontra" (Melo, 2005: 17).

Talvez a principal contribuição social da pesquisa de Melo tenha sido fazer um levantamento inédito do vocabulário da variante do chibi falado por aquela comunidade, cooperando com sua perpetuação, já que, como diz Cohen (2003: 84), "os vestígios da língua que se extingue estão presentes em contextos sociais específicos". Referindo-se à sua pesquisa, Melo (Ibid.: 29) afirma que seu objeto é a

...língua dos Calon do Município de Mambaí-GO, que apresenta níveis de desgaste (que serão oportunamente tratados) nos vários componentes gramaticais, em virtude, principalmente, da frequência e da intensidade da interação dos ciganos com o mundo dos gadje [não ciganos], no qual são forçados a se inserirem em nome da sobrevivência.

Outra pesquisa que gerou uma aplicação social foi a que desenvolvi, no ano de 2016, entre os Calon Gaúchos do chamado "Povo do Biráco", itinerantes no estado do Paraná, um pequeno grupo que nunca havia sido pesquisado por acadêmicos. Ao tratar do preconceito e da discriminação, relatei um ataque de não ciganos, quando certa madrugada, naquele mesmo ano, no município de Rolândia, Paraná, fogos de artifício foram lançados para dentro de uma das tendas certa noite, quase atingindo uma bebê. Vejamos um pequeno trecho do relato (Shimura, 2017: 117):

Logo ouvimos um veículo em alta velocidade e entendemos o que havia acontecido. Era comum nas outras vezes que eu dormi no acampamento, especialmente finais de semana, durante a noite ouvir não ciganos que passavam em carros em frente ao acampamento xingarem os ciganos e gritarem em alta voz 'ordenando' aos ciganos que 'fossem embora'. Provavelmente um ou alguns desses 'agentes anticiganos' cometeu esse ato como uma forma de pressionar o acampamento a ir embora de Rolândia”.

O material da pesquisa foi publicado e despertou o interesse de outras comunidades ciganas associadas àquela grupo, de forma que muitos líderes solicitaram à nossa associação ${ }^{6}$ que elaborássemos uma cartilha de direitos básicos que os auxiliasse nas mais diversas situações onde encontravam resistências do poder público, desde um simples atendimento em postos de saúde até ao contato com parlamentares que poderiam ouvir suas demandas por políticas públicas.

\footnotetext{
${ }^{6}$ Associação Social de Apoio Integral aos Ciganos (ASAIC). Atuante desde 2002, organizou-se juridicamente somente em 2013, sendo formada por ciganos e não ciganos de diferentes áreas profissionais, como advogados, assistentes sociais, sociólogos etc. Cf. www.asaic.com.br
} 
Uma vez lançada a cartilha, em 2017, houve uma aproximação maior do Governo do Estado do Paraná com as questões apresentadas pelos ciganos itinerantes da região.

No final de 2018 dois ciganos itinerantes dessas mesmas comunidades assumiram posições de representatividade estadual no Conselho de Povos Indígenas e Comunidades Tradicionais (CPICT/PR) do Departamento de Direitos Humanos e Cidadania da Secretaria da Justiça, Trabalho e Direitos Humanos do Estado ${ }^{7}$.

Por que pesquisar ciganos então? Os desdobramentos sociais das pesquisas podem ser motivadores consideráveis para que estudantes se dediquem a investigar as mais diferentes realidades do complexo universo da ciganidade.

\section{Caminhos e reflexões}

No contexto brasileiro a pesquisa com ciganos ainda é escassa se comparada ao volume que vemos na Europa, com tantos livros e pesquisas em andamento, no entanto é perceptível que estamos nos desenvolvendo. Penso que esse crescimento está relacionado a conquistas políticas dos povos ciganos junto a governos, como é o caso do Dia Nacional do Cigano, decretado em 2006 (BRASIL, 2006). Por mais que temática cigana já estivesse no radar da academia e do Estado anteriormente, esse decreto inaugurou um momento histórico de visibilidade social como nunca antes, dando aos ciganos brasileiros uma atenção específica dentro das estruturas políticas. Com isso percebeu-se um despertando de interesse por parte de estudantes, especialmente das áreas de história e ciências sociais.

Sobre isso é importante ressaltar que toda ação pública de um governo produz alguma ressonância social, de forma que o interesse da mídia e da sociedade resultam em reações que não raras vezes se refletem na academia. Nesse sentido, há de se entender que essas esferas compartilham sinergias, conexões e certa interdependência, uma vez que um tema de destaque governamental, seja qual for, provoca a curiosidade de todos e, como sabemos, o interesse do pesquisador sempre tem um despertador que ativa sua criatividade e o põe em contato com um tema. Como afirma Deslandes (2016: 29), uma pesquisa "não surge espontaneamente, unicamente pela vasta experiência ou pelo grande compromisso social de um pesquisador em certa temática".

Quanto a isso sabemos que, primeiro, é importante reconhecer que historicamente nenhum governo brasileiro deu grande importância aos povos ciganos e os que trataram da temática o

${ }^{7}$ Cf. PARANÁ. Conselho dos Povos Indígenas e Comunidades Tradicionais do Paraná elege novos membros. Disponível em: http://www.dedihc.pr.gov.br/modules/noticias/article.php?storyid=4501 Acessado em 06 nov. 2019. 
fizeram de forma generalizada e minimizada, como uma "nota de rodapé" de suas ações. Isso torna o decreto que estabeleceu o Dia Nacional do Cigano como algo realmente importante, a partir do qual outras políticas públicas específicas foram criadas ${ }^{8}$. Segundo, as poucas ações governamentais em favor desse público geralmente não chamaram a atenção das "grandes mídias", mas atraíram, quando muito, somente o olhar de grupos de comunicação regionais, específicos ou acadêmicos. Terceiro, de forma geral, antes do surgimento de espaços de destaque no poder público, quando a temática cigana eventualmente recebia alguma atenção, raramente era contextualizada positivamente, mas associada a uma imagem historicamente negativa, reproduzindo estereótipos: criminosos, estelionatários, trapaceiros, bagunceiros etc. Reconhecemos que esse quadro se tem modificado nos últimos anos com as notas voltadas à notícias acerca de atos de reinvindicação realizados por ativistas juntos a governos.

Como um pequeno exercício, fiz uma pesquisa rápida no site de busca Google $e^{9}$, colocando como assunto "ciganos" - em português, e encontrei "aproximadamente 2.850 .000 resultados"10. Ao pesquisar sobre "ciganos e direitos humanos" encontrei "aproximadamente 242.000 resultados" e ao procurar por casos de conflitos internos entre ciganos o site acusou ter identificado "aproximadamente 687.000 resultados". O que mais rendeu identificações de sítios foi quando procurei por "pesquisa ciganos", acusando "aproximadamente 4.010 .000 resultados".

Certamente os resultados desse exercício podem ser postos à prova, relativizados, considerando dispositivos da internet, momento e disponibilidades, mas com isso só quero chamar à atenção para o fato de que já temos hoje, diferente de anos anteriores, mais acesso à conteúdos acerca de ciganos. A internet potencializou a pesquisa bibliográfica e em outras modalidades. Não tenho dúvidas de que uma pesquisa dessas merece um detalhamento que apresente maiores informações e nos permita investigar com mais cuidado esse cenário, mas hoje temos ao menos uma noção do quanto a temática está acessível - independente de qualidade - nesse tipo de ferramenta de busca. Dentre os resultados dessas pesquisas encontrei uma infinidade de títulos e assuntos que representam as mais diferentes perspectivas.

Em idioma português (Brasil) não encontrei muitos artigos científicos, sendo a grande maioria dos links relacionados dirigidos à notas e matérias jornalísticos ou à pequenos artigos de blogs. Percebi que dentre as notícias há muitas tragédias, tais como conflitos entre famílias ciganas ou crimes envolvendo pessoas de etnia cigana, e isso de forma exaustiva, o que exigiria

\footnotetext{
${ }^{8}$ Há poucas políticas públicas específicas para ciganos no Brasil. Cf. Guia de Políticas para Ciganos. Disponível em: https://bibliotecadigital.mdh.gov.br/jspui/handle/192/309 Acesso em 29 nov. 2019.

${ }^{9}$ Cf. www.google.com.br

${ }^{10}$ Sabemos que esse número pode alterar dependendo de variantes próprios da internet.
} 
uma pesquisa à parte, específica, que tratasse do tema do estigma/estereótipo. Diante disso não é de admirar que um fato inédito e positivo na história dos ciganos no Brasil, como a visita de uma Ministra de Estado a uma comunidade cigana (Floresta, 2019), tenha recebido bem menos destaque midiático do que a prisão de ciganos envolvidos em conflitos intergrupais (Santana, 2019)! Também não é de admirar, infelizmente, que casos isolados envolvendo crimes cometidos por indivíduos ciganos sejam usados como justificativa para generalizações e condenação de "todos" os ciganos.

Essa análise nos remete para a necessidade da desconstrução de estereótipos, já consagrados mundialmente e extremamente prejudiciais para a vida de milhares de ciganos. Em maio de 2019 acompanhei o caso do cigano Juan Jesús Fernández que assassinou o Deputado Héctor Olivares e seu assessor Miguel Yadón em frente ao Palácio Legislativo, em Buenos Aires, na Argentina. Segundo informações o assassinado ocorreu motivado por uma briga gerada por ciúmes, já que Yadó tinha envolvimento com a filha de Fernández. Diante disso as investigações apontaram que o alvo de Fernández era somente Yadó. Na época seis pessoas foram presas, todas de etnia cigana, pelo que a Ministra de Segurança da Argentina, Patrícia Bullrich, declarou que se tratava de um "clã de mafiosos ciganos": "Todo el 'clan mafioso de gitanos' detenidos [...] Gracias a Interpol Uruguay. ¡El que las hace las paga!!!” (Cf. Olivares, 2019).

Em resposta à Ministra Bullrich a pesquisadora e ativista Aline Miklos, que é cigana brasileira e vive em Buenos Aires rebateu: “QQué pasa por la cabeza de Bullrich? Tiene el estereotipo gitano muy aprendido, nunca leyó una línea del tema" (Vásquez, 2019). Afirmou ainda que é "desatinado englobar a toda la comunidad gitana y ligarla a conductas delictivas, por el sólo hecho que alguno de sus miembros puede haber cometido un ilícito" (Idem).

E aí está um dos grandes temas a serem considerados pelo pesquisador de ciganos: os obstáculos relacionados aos estereótipos. Quando digo isso estou me referindo à evidente distância que as comunidades ciganas mantêm do universo não cigano. Já tratamos sobre o motivo óbvio dessa ciganofobia, que é o eixo estrutural a ser superado nessas relações, mas é necessário considerar a tão conhecida lei de Newton: “a toda ação há sempre uma reação oposta e de igual intensidade"! Sendo assim sabemos os motivos que levam indivíduos e comunidades ciganas a optar pela distância para com as sociedades envolventes. E é nesse campo que existem estereótipos anti-gajen", ou "anti-não-ciganos". Se por um lado "não ciganos" tornam os ciganos invisibilizados e, portanto, excluídos dos sistemas sociais de direitos, muitos ciganos retribuem

\footnotetext{
${ }^{11}$ O termo gajen é o plural de gajon (masculino) e gajin (feminino) e significa "não cigano" em chibi, idioma falado pelo povo Calon brasileiro. Os termos equivalentes em idioma Rom é gadjê e para os Calon espanhóis e portugueses é payos.
} 
essa atitude da mesma forma, invisibilizando indivíduos e estruturas sociais que lhes não interessam.

Já vi pesquisadores sendo totalmente desprezados por comunidades ciganas em seus empreendimentos de investigação. Por que? Porque não lhes interessava! E aí está outro ponto de grande relevância. Um indivíduo ou comunidade cigana precisa ser encorajada e incluída em todo processo de pesquisa. Isso significa torná-lo participante. E quanto a isso cito mais uma vez o Código de Ética do Antropólogo e da Antropóloga: “constituem direitos das populações que são objeto de pesquisa o direito de autoria e coautoria das populações sobre sua própria produção cultural"! É o empoderamento! Em nossa associação temos trabalhado dessa forma há anos, utilizando a ideia de que se empoderamos nossos interlocutores eles tendem a se engajar pela pesquisa e se eles se engajam então desenvolvem um senso de pertencimento.

Quando realizei minha pesquisa sobre uma comunidade autointitulada "povo do Biráco", ciganos Calon itinerantes que vivem na região Sul do Brasil, tomei a decisão de empoderá-los como co-autores. Eu já os conhecia há alguns anos, no entanto estava agora estabelecendo uma nova relação, a de pesquisador/pesquisado. Para o êxito do trabalho foi imprescindível firmar uma dinâmica de proximidade e interdependência, pelo menos no que se referia às informações que eu buscava do grupo. Ao perceberem isso se mostraram engajados para que o conteúdo que estava sendo confeccionado fosse o melhor possível, fornecendo detalhes importantes para o desenvolvimento do trabalho. Seguindo esse caminho obtive êxito em mostrar aos meus interlocutores que o resultado da pesquisa seria útil para descontruir estereótipos, promover sua cultura local e aproximá-los de estruturas de poder social das quais eles precisam, como prefeituras, forças policiais, postos de saúde, escolas etc.

Ainda pensando em obstáculos, não podemos deixar de reconhecer que o distanciamento entre ciganos e as sociedades envolventes resultaram em lacunas imensas no campo bibliográfico. Não esqueço da breve e agradável conversa que tive com o famoso antropólogo Roque de Barro Laraia, no ano de 2016, durante a 30ª Reunião Brasileira de Antropologia, em João Pessoa, Paraíba. Ao comentar sobre a temática cigana ele me contou que há muitos anos, antes de iniciar seus estudos com indígenas, tentou pesquisar uma comunidade cigana, mas "a comunidade se fechou". Moonen (2013: 6) menciona algo semelhante, ao citar a constatação da antropóloga Sutherland, que durante dois anos realizou pesquisa entre ciganos Kalderash e Lowara na Califórnia, nos Estados Unidos: “os rom são extremamente reservados e desconfiados de não-ciganos e, em geral, não desejam que o mundo exterior conheça sobre eles". O medo da exposição, a desconfiança para com não ciganos e as experiências traumatizantes com outros 
pesquisadores devem ser levadas em conta. Fato é que temos uma grande falta de bibliografias por conta dessas e outras barreiras.

No Brasil, apesar de percebermos um considerável avanço dos estudos ciganos, ainda carecemos de mais produções que contribuam para novos empreendimentos. Nos idiomas inglês e espanhol há muito mais materiais, no entanto, mesmo nessas línguas, se pensarmos na necessidade de produções contextuais, que descrevam e destaquem realidades locais, de forma geral, ainda há muitas lacunas. Moonen (Ibid.: 7) também trata desse assunto ao dizer que a dificuldade de obter bibliografia cigana para realizar pesquisas é citada por vários autores.

Sant'Ana (1983), por exemplo, cita apenas cinco estrangeiros (Block 1936, Bloch 1962, Clébert 1965, Yoors 1967, Leland 1971), e três brasileiros (Mello Moraes Filho 1886, China 1936 e Dornas Filho 1948). Nada mal para quem realizou sua pesquisa no início da década de 70. Locatelli (1981), por sua vez, não cita um único livro de um ciganólogo estrangeiro ou brasileiro. Como justificativa apresenta a "quase inexistente" bibliografia nas principais bibliotecas do Rio Grande do Sul e de outros Estados.

Para concluir quero voltar a destacar a aplicabilidade das pesquisas com ciganos. Artigos e livros, fotografias e outras produções podem fazer uma grande diferença no que diz respeito ao combate ao anticiganismo. Penso que os pesquisadores da presente geração, com fortes noções acerca dos direitos humanos, são imprescindíveis para a proteção de populações ciganas, exercendo um papel de importância singular: informar a alteridade, construir pontes e municiar seus interlocutores para a resistência.

Conhecendo a história dos ciganos percebemos que uma de suas virtudes coletivas que mais foi acionada ao longo dos séculos foi a resiliência. Sob fortes perseguições requintadas de crueldade esses povos conseguiram se reerguer em diversas situações. No entanto, é triste e vergonhoso pensar que muito de seus sofrimentos foi causado por pretensos "pesquisadores" como Grellmann e Borrow (Cf. Moonen, 2000a : 64-69). Cabe a esta geração de pesquisadores retribuir e contribuir com as comunidades com produções de qualidade e dignas de humanidade, para que enfim, no que depender da academia, ciganos não mais precisem, como disse Manush Romanov (Cf. Fonseca, 1996: 340), "passar a vida toda de joelhos". 


\section{Bibliografia}

Barth, F. (2011 [1969]). Grupos étnicos e suas fronteiras . In: Poutignat, P. \& Streiff-fenart, J.. Teorias da etnicidade: seguido de grupos étnicos e suas fronteiras de Fredrik Barth. Tradução Elcio Fernandes. 2 ed. São Paulo: Ed. Unesp.

BRASIL (2019). Decreto $n^{\circ} 10841$, de 25 de maio de 2006. Institui o Dia Nacional do Cigano. Disponível em: http://www.planalto.gov.br/ccivil_03/_Ato20042006/2006/Dnn/Dnn10841.htm Acesso em 01 de nov. 2019.

BRASIL (2010). Lei n ${ }^{\circ} 12.288$, de julho de 2010. Institui o Estatuto da Igualdade Racial; altera as Leis nos 7.716, de 5 de janeiro de 1989, de 13 de abril de 1995, de 24 de julho de 1985, e 10.778, de 24 de novembro de 2003.

China, J.B. D’O. (1936). Os ciganos do Brasil. São Paulo: Imprensa Official do Estado.

Deslandes, S. F. (2016). O projeto de pesquisa como exercício científico e artesanal intelectual, pp. 29-55. In: Minayo, M. C. de S. (org); Deslandes, S. F.; Gomes, R.. Pesquisa social: teoria, método e criatividade. Petrópolis, RJ: Vozes.

FLORESTA (2019). Floresta Recebe a Visita da Ministra Damares Alves. Prefeitura Municipal de Floresta. Sexta-feira, 25 de outubro de 2019. Disponível em: http://www.floresta.pr.gov.br/index.php?sessao=b054603368vfb0\&id=1402527 Acesso em 23 out. 2019.

Fonseca, I. (1996). Enterrem-me em pé: a longa viagem dos ciganos. Trad. José Rubens Siqueira. São Paulo: Companhia das Letras.

Laplantine, F. (2007). Aprender antropologia. Tradução Marie-Agnès Chauvel. São Paulo: Brasiliense.

Melo, F. J. D. (2005). Os ciganos calon de Mambaí: a sobrevivência de sua língua. Brasília: Thesaurus.

Moonen, F. (2011). Anticiganismo e políticas ciganas na Europa e no Brasil. 3 edição digital revista e atualizada. Recife. Disponível em: http://www.dhnet.org.br/direitos/sos/ciganos/a_pdf/1_fmanticiganismo2011.pdf Acesso em 21 nov. 2019.

Moonen, F. (2000b). Ciganos calon na Paraíba, Brasil (1993). E-texto n. 4. Núcleo de Estudos Ciganos.

Moonen, F. (2013). Ciganos e ciganólogos: estudar ciganos para quem e para quê? Disponível em: http://docplayer.com.br/66270683-Ciganos-e-ciganologos-estudarciganos-para-quem-e-para-que.html Acesso em 25 nov. 2019.

Moonen, F. (2000a). Rom, sinti e calon - os assim chamados ciganos. E-texto n. 1. Recife: Núcleo de Estudos Ciganos.

Moreira Neto, C. (1959). Relatório sobre a situação atual dos índios Kayapó. Revista de Antropologia, 1959.

Olivares, H. (2019). Tras la detención del principal sospechoso. Patricia Bullrich: Todo el clan "clan mafioso de gitanos" detenido. Clarín. 10/05/2019, 9:59. Disponível em: 
https://www.clarin.com/politica/patricia-bullrich-caso-yadon-esclarecido-crimenpolitico_0_tk3ozhUmy.html Acesso em 01 nov. 2019.

Piasere, L. (2018). Anticiganismo. $1^{\text {a }}$ ed. Ciudad Autónoma de Buenos Aires: Voria Stefanovsky Editores.

Rocha, E. (2006). O que é etnocentrismo. São Paulo: Brasiliense, 2006.

Santana, V. (2019). Irmãos ciganos são presos suspeitos de matar parentes devido à rixa de mais de 200 anos. G1. 04/11/2019 12h29. Disponível em:

https://g1.globo.com/go/goias/noticia/2019/11/04/irmaos-ciganos-sao-presos-suspeitos-dematar-parentes-devido-a-uma-rixa-familiar-de-mais-de-200-anos.ghtml Acesso em 24 out. 2019.

Shimura, I. (2017). Ser cigano: a identidade étnica em um acampamento calon itinerante. Amazon.

Vázquez, P. \& Miklos, A. (2019). "El pueblo gitano está absolutamente desamparado". El Furgón. 14 mayo, 2019. Disponível em: https://elfurgon.com.ar/2019/05/14/aline-miklosel-pueblo-gitano-esta-absolutamente-desamparado/ Acesso 29 out. 2019. 



\title{
Capítulo 4. \\ Será possível a decolonização ${ }^{1}$ dos Estudos Ciganos? \\ Um ensaio sobre a relação ciganos e ciência
}

\author{
AluíZIO DE AZEVEDO SILVA ${ }^{2}$ \\ Cigano Kalon, jornalista, mestre em Educação e doutor em Comunicação e Saúde \\ luiju25@gmail.com
}

Resumo: Este trabalho apresenta algumas reflexões acerca da conflituosa relação entre a ciência social e os grupos periféricos ou movimentos sociais que os representam, caso das comunidades ciganas em Brasil e Portugal. Essas reflexões se dão com base em duas matrizes acadêmicas: os estudos decoloniais e os estudos culturais. E se desdobram sobre a possibilidade de tornar os estudos ciganos decoloniais e vê-los como um lugar de luta e fortalecimento das pessoas ciganas, suas identidades, demandas sociais e lutas por inclusão e visibilidade social, além de cidadania plena em todos os âmbitos.

Palavras-Chave: Ciganos, ciência, política, movimentos sociais

\footnotetext{
${ }^{1} \mathrm{O}$ conceito de decolonização ou decolonialidade foi cunhado por autores do grupo modernidade / colonialidade / decolonialidade. Essa corrente evidencia a produção de uma geopolítica do conhecimento (Henrique Dussel) eurocêntrica-estadunidense, que instalou uma matriz colonial de poder (Walter Mingolo), de saber (Egardo Landers) e do ser (Maldonado-Torres), permitindo e justificando a construção de um sistema-mundo moderno que esconde uma face oculta colonial (Anibal Quijano), responsável por aniquilar ou excluir saberes e conhecimentos produzidos fora dos centros europeus e norte-americano. A decolonização busca romper com o paradigma hegemônico da ciência moderna ocidental e com o imperialismo capitalista racista, lançando novos olhares acerca de filosofias, saberes e práticas (epistemologias); modos de ação e organização sociocultural e formas de vida de povos não-europeus, especialmente, os que constituem a América Latina, a exemplo de indígenas e ciganos. Para saber mais sobre o conceito de decolonização e decolonialidade ver em: QUIJANO, A. Colonialidade do poder, Eurocentrismo e América Latina. In: LANDER, E. Colonialismo; Modernidad; Capitalismo; Poder Politico; Sociedad; Historia; Eurocentrismo; America Latina. CLACSO, Consejo Latinoamericano de Ciencias Sociales, Buenos Aires, 2005. Disponível em: <http://biblioteca.clacso.edu.ar/clacso/sur-sur/20100624103322/12_Quijano.pdf>

${ }^{2}$ Aluízio é cigano da etnia kalon, possui graduação em Comunicação Social - Jornalismo e Ciências Sociais pela Universidade Federal de Mato Grosso (UFMT), especialização em Cinema (Universidade de Cuiabá - Unic), Mestrado em Educação (UFMT) e doutorado pelo Programa de Pós-graduação em Informação, Comunicação e Saúde pela Fundação Oswaldo Cruz (Fiocruz). É técnico em comunicação social - jornalista concursado do Ministério da Saúde do Brasil e atualmente presta serviços como Chefe da Seção de Apoio Institucional e Articulação Federativa (SEINSF) da Superintendência Estadual do Ministério da Saúde em Mato Grosso (SEMS-MT). Também é professor do curso de Artes Visuais da Universidade Estadual de Mato Grosso (Unemat). emails: luiju25@gmail.com e aluizio.silva@ saude.gov.br
} 
Abstract: This paper presents some reflections on the conflicting relationship between social science and the peripheral groups or social movements they represent, such as Roma communities in Brazil and Portugal. These reflections can be based on two academic matrices: decolonial studies and cultural studies. He is unfolding on the possibility of creating decolonial studies and seeing them as a place of struggle and empowerment of people, their identities, social demands and struggles for selection and social visibility, as well as full citizenship in all individuals.

Keywords: Romani, science, politics, social movements

\section{Alinhando múltiplas identidades e diferentes saberes}

As reflexões aqui apresentadas foram inicialmente pensadas para uma participação como convidado do "Seminário Internacional Ciganos em Portugal, Espanha e Brasil: analisando contextos, demandas e processos identitários”. O evento ocorreu no Instituto Universitário de Lisboa (Iscte), em Portugal, nos dias 03 e 04 de junho de 2019, reunindo pesquisadores da temática dos três países e ativistas do movimento social cigano brasileiros, espanhóis e portugueses. Fui convidado a participar da mesa redonda "Contextos, participação e mediação"

$\mathrm{Na}$ ocasião, fiz um roteiro de fala de maneira a apresentar alguns dos principais resultados emergidos na tese ${ }^{3}$ de doutorado que defendi no ano de 2018 na Fundação Oswaldo Cruz (Fiocruz, Rio de Janeiro), com doutoramento sanduíche na Universidade Aberta de Lisboa (UAb), cujo objeto teórico proposto versou sobre "a produção social dos sentidos em processos interculturais da saúde cigana nesses dois países”. Enfatizei, por exemplo, que os contextos (existenciais, situacionais, de saúde, etc.) e demandas das comunidades ciganas (lidas como lutas por visibilidade social e inclusão cidadã) são fundamentais para compreensão e análise da apropriação das políticas públicas de saúde para ciganos no Brasil e em Portugal.

Nesta investigação, levantei as principais demandas da área da comunicação e saúde e sua relação histórica com os contextos sociais, econômicos e culturais de tais comunidades, fazendo emergir questões como as lutas por igualdade racial e o direito à comunicação para a cidadania plena (Silva, 2018). Entretanto, agora, ainda que estes temas estejam transversalmente integrados e não poderia ser diferente, pois relacionam-se diretamente ao universo cigano e ao trabalho

\footnotetext{
${ }^{3}$ Silva, Aluízio de Azevedo Júnior. Produção Social de Sentidos em Processos Interculturais de Comunicação e Saúde: a apropriação das políticas públicas de saúde para ciganos no Brasil e em Portugal. (Doutorado) - Programa de Pós-Graduação em Informação e Comunicação em Saúde, Instituto de Comunicação e Informação Científica e Tecnológica em Saúde, Fundação Oswaldo Cruz (Fiocruz), 2018.
} 
que desenvolvo como ativista do movimento cigano ${ }^{4}$ e pesquisador; pretendo trilhar outro caminho, aprofundando algumas reflexões e análises sobre este orgulho, que senti ao ser reconhecido como militante cigano que faz mediação institucional; mas, ao mesmo tempo, um incômodo de, como pesquisador do tema, não estar prestigiado como tal, dialogando com outros pesquisadores desse campo.

Me chamou atenção o fato que todos os outros oito convidados da mesa eram pessoas ciganas, incluídas na sociedade portuguesa e merecido destaque no movimento social cigano. Ainda mais porque sabemos que não é trivial termos tantas pessoas ciganas bem sucedidas em espaços acadêmicos, dado ao histórico de exclusão e abandono escolar da maioria das pessoas ciganas, inclusive ${ }^{5}$ com altos índices de analfabetismo (Silva, 2009).

Tive o prazer de compartilhar a mesa com a dinamizadora sócio cultural, Sônia Matos, os mediadores sociais Eduardo Cabeças (Câmara de Maia), Bruno Oliveira (Centro Hospitalar Universitário Central de Lisboa), Carlos Silva (Agrupamento de Escolas Mãe D’Água), Vítor Teles (Câmara Municipal de Torres Vedras); e os ativistas Piménio Ferreira, Licínio Fernandes (Porto) e Bruno Oliveira, mediador cigano na área da saúde. A única "senhora" a participar da mesa foi a professora Olga Magano, do CIES-Iscte, uma das organizadoras do evento e pesquisadora da temática, que realizou a mediação acadêmica.

${ }^{4}$ Realizo ativismo no movimento cigano desde o ano de 2012, por meio do trabalho free style e desde 2017, através do movimento associativista, por intermédio de assessoria de comunicação e ciência da Associação Estadual das Etnias Ciganas de Mato Grosso (AEEC-MT), cujas informações podem ser acessadas no seguinte link: https://aeecmt.blogspot.com/. Participei de vários grupos de trabalho e diálogos junto a órgãos públicos responsáveis pelas políticas públicas afirmativas voltadas as populações e comunidades tradicionais/minorias étnicas, representando as comunidades ciganas, a exemplo de interlocução junto ao Ministério da Mulher, da Família e dos Direitos Humanos (MMFDH) do Brasil e ao Comitê Estadual dos Povos e Comunidades Tradicionais de Mato Grosso (CEPCT-MT).

\footnotetext{
${ }^{5}$ Não há uma essência cultural cigana única, mas sim múltiplas identidades, com distintos grupos, subgrupos, que variam conforme a região e o país onde se movimentam, sendo que costumam se autoidenficar de três formas: 1 ) os ROM, ou Roma, que falam a língua romani; são divididos em vários subgrupos (sic), com denominações próprias, como os Kalderash, Matchuaia, Lovara, Curara etc.; são predominantes nos países balcânicos, mas a partir do Século XIX migraram também para outros países europeus e para as Américas; (2) os SINTI, que falam a língua sintó e são mais encontrados na Alemanha, Itália e França, onde também são chamados Manouch; (3) os CALON, KALON ou KALÉ, que falam a língua caló, os "ciganos ibéricos", que vivem principalmente em Portugal e na Espanha, onde são mais conhecidos como Gitanos, mas que no decorrer dos tempos se espalharam também por outros países da Europa e foram deportados ou migraram inclusive para a América do Sul (Moonen, 2011, p. 05 e 06).

6 “Senhores', 'senhor', 'senhora' é o modo como as pessoas ciganas costumam chamar os não-ciganos portugueses. Diz-se que o motivo é por os ciganos estarem sempre a vagar, nômades, sem qualquer propriedade de terra, enquanto os portugueses são os senhores donos das casas, das terras, dos bens móveis.
} 
Ao me deparar com esta situação, imediatamente, surgiram alguns questionamentos e, posso até dizer, que conflitos entre as múltiplas identidades que me constituem. Como cigano brasileiro da etnia kalon, artista e ativista do movimento social romani ${ }^{7}$, senti orgulho em estar ao lado de reconhecidos militantes portugueses, participando de um evento legitimado cientificamente. Boa parte deles, inclusive, mantenho contatos virtuais e reais, como Piménio, Eduardo, Bruno Prudêncio e Bruno Oliveira e sempre nos comunicamos sobre as demandas e problemas de nossas comunidades, entre outras, trocando experiências e reflexões.

Aliás, foram os próprios que indicaram o meu nome à organização para participação no evento. Conheci os "primos" em 2017, durante os seis meses que passei em Portugal, realizando o estágio de doutoramento sanduíche no Centro de Estudos das Migrações e das Relações Interculturais (CEMRI) da Universidade Aberta de Lisboa (UAb). Ao lado de outras pessoas ciganas com quem dialoguei para realizar a investigação, eles foram importantes interlocutores, participando da pesquisa de campo e contribuindo para a análise do objeto (teórico e empírico) proposto na tese. Defendida na Fundação Oswaldo Cruz (Fiocruz, Rio de Janeiro, 2018), a investigação voltou-se para a análise da apropriação (comunicacional) das políticas de saúde para ciganos no Brasil e em Portugal.

Mas é exatamente aí que entram as outras duas faces que incorporam o meu ser e que de certa forma deixam a voz de cigano militante em alerta: o pesquisador que estuda o seu próprio universo cultural, que na tangente é fortalecida pelo comunicador da saúde pública que atua no Sistema Único de Saúde (SUS) ${ }^{8}$. A minha preocupação era na tese e é nesse texto a de que essas identidades sociais de pesquisador e de comunicador do SUS, legitimadas nas relações de saber e de poder a que institucionalmente se vinculam, pudessem eclipsar as vozes e olhares do cigano.

\footnotetext{
${ }^{7}$ A palavra "cigano" foi criada pela sociedade majoritária de maneira a homogeneizar diferentes etnias sob uma mesma nomenclatura. Historicamente, este nome, em várias línguas europeias (gypsy no inglês, ou gitano no espanhol, por exemplo) foi carregado de estereótipos e uma carga semântica muito negativa. O que motivou o movimento cigano europeu a propor uma mudança nos termos nomeadores para tais grupos, substituindo-se a palavra "cigano" e seus equivalentes nas línguas europeias pelo termo "Rom", "Romá" ou "Romani", como nova autodenominação, menos carregada de estereótipos. Mas, esta nova terminologia não está isenta de conflitos, na medida em que é questionada especialmente pelos Kalon e pelos Sinti, que não se sentem representados nesse termo, que diz respeito a forma com que grupos e subgrupos da etnia Rom se autonomeiam, um fato que demonstra como a identidade só pode ser compreendida como um processo negociado e político de diferenciação. Ainda que haja uma tendência para nomear a todas as etnias ciganas de Rom ou Romá, inclusive com indicação da ONU para tal; não podemos classificá-las desta forma. Por outro lado, a palavra Romani tanto é um patronímico de "Romá" ou de cigano, como é utilizada para nomear a língua dos grupos Rom. Se seguíssemos ao pé da letra, não poderia ser utilizada para classificar a todas as etnias ciganas, mas por uma questão de fluidez aqui nesse texto, romani aparece como sinônimo do termo "ciganos" e para indicar a todos os ciganos, sejam eles Rom, Sinti ou Kalon (Silva, 2018: 46).
}

\footnotetext{
${ }^{8}$ Desde 2012 atuo como jornalista concursado do Ministério da Saúde do Brasil.
} 
Portanto, posso dizer que as reflexões que trago articulam experiências e lugares de fala dessas múltiplas identidades, mostrando como esta relação é tensa e delicada, podendo ser colonizadora ou emancipadora. Esse conflito faz emergir alguns questionamentos acerca desta relação, que pode ser representada por outras faces relacionais, como: 1) pesquisadores do universo romani e os pesquisados ciganos - ativistas de seu movimento social ou pessoas "comuns" da comunidade; 2) teoria e discursos/saberes políticos; ou 3) epistemologia científica e saberes/narrativas ciganas.

Segundo Gayatri Spivak (2010), essas camadas de relações revelam um incômodo ao ocuparmos o lugar de fala e de interlocução (Araujo, 2002), de pesquisadores que estudam grupos "subalternos" ou colonizados, caso dos grupos ciganos, seja no Brasil ou em Portugal: "pode o subalterno (no nosso caso os ciganos) falar(em)? Pode $(\mathrm{m}) \mathrm{o}(\mathrm{s})$ subalterno(s) (ciganos) participar(em) do processo científico e/ou político sem ocupar um lugar de inferioridade?"

Em outros termos, as pessoas romani participam ativamente dos conhecimentos produzidos acerca do seu universo e depois este conhecimento é apropriado pelas suas comunidades, de forma a melhorar suas vidas? Podem elas analisar teoricamente as temáticas que são estudadas? Sendo o pesquisador um cigano, subjetivamente, ele é "objeto" da própria pesquisa?

É sobre essas distintas problemáticas e camadas, que pretendo aprofundar o diálogo nesse texto. Primeiro apontando como essas relações, estabelecidas tendo por parâmetro um modo de fazer científico moderno, opressor e colonizador, precisam ser revistas para a produção de um conhecimento emancipatório e a construção de uma relação dialógica e sem hierarquias entre pesquisados e pesquisadores e seus distintos saberes. Especialmente quando esta relação diz respeito a sujeitos de pesquisa que estão em situação de desigualdade ou exclusão. E segundo observando, a partir dos Estudos Culturais, que a ligação entre a teoria e a política, leia-se movimentos sociais, é fundamental para avanços dos grupos pesquisados e da teoria política e sócio-cultural (Araujo, 2002; Barbero, 1997).

\section{Construindo uma ligação entre teoria-epistemologia e os conhecimentos da filosofia cigana}

Pensar sobre essas questões me fez perceber algumas ponderações epistemológicas importantes, a exemplo da relação entre pesquisadores e grupos sociais, que se traduzem em várias camadas de relações: sujeito x objeto, saber científico x outros saberes e se configuram por relações de poder que estão entrelaçadas e são contraditórias, conflituosas e desiguais. O que remete a outra questão: "a ideia de que o cientista social não pode impor as suas preferências normativas por carecer de um ponto de vista privilegiado para o fazer" (Santos, 2002: 17). 
A pergunta que sempre serviu de ponto de partida para a teoria crítica - de que lado estamos? tornou-se para alguns uma pergunta ilegítima, para outros uma pergunta irrelevante e para outros, ainda uma pergunta irrespondivel (...) se alguns, por acharem que não têm de tomar partido, deixaram de se preocupar com a pergunta e criticam quem com ela se preocupa, outros, talvez a geração mais jovem de cientistas sociais embora gostassem de responder à pergunta e tomar partido, veem, por vezes, com angústia, a dificuldade aparentemente cada vez maior, de identificar as posições alternativas em relação as quais haveria que tomar partido".

(Santos, 2002: 17)

Tomar partido em qualquer investigação científica do universo cigano, inclusive no doutorado e nessa comunicação, enunciando de que lado estou como pertencente a esta etnia e pesquisador; é crucial e ajuda a perceber os deslizamentos e deslocamentos entre as narrativas das múltiplas identidades (Hall, 2003) que compõem o meu ser, a começar pela cigana, que compartilho com aqueles a quem pesquisei. Contudo, aplicar esse posicionamento teórico-epistemológico, significa ir contra toda uma corrente hegemônica na ciência ocidental moderna.

O paradigma convencional da ciência moderna exige a delimitação de dois aspectos centrais: os teóricos e os metodológicos, elementos que legitimam ou rechaçam a validade do conhecimento. Mas tende a excluir do processo a discussão acerca do modo como foi produzido, isto é, as condições de articulação e negociação e seu impacto e responsabilidade acerca do assunto e grupos estudados. Pesquisadores fazem e refazem ciência nesta fórmula, mas não põe em foco o problema de sua epistemologia/ontologia e isso cria uma ilusão de que é um sistema autossuficiente: o único capaz de uma análise e representação verdadeiras da realidade.

Privilegiando uma epistemologia que opera a partir de uma "descontextualização social, política e institucional do conhecimento", o modus operandi da ciência moderna serviu "de quadro teórico legitimador de todas as formas de dominação" (Santos e Meneses, 2009: 183184), sendo responsável por justificar muitas exclusões ou apagamentos de outras maneiras de produção de conhecimentos populares, incluindo aqueles produzidos pelas pessoas e comunidades ciganas. Nessa perspectiva, surge uma questão: "e aqueles que estão fora dos centros acadêmicos que produzem conhecimento eurocêntrico? Certamente verão que a ciência não lhes permite apropriar do mundo como deles próprios" (Idem).

Trazendo para o nosso cenário: e aqueles que produzem saberes de resistência, na luta, em situação de desigualdade social ou exclusão, colocando em prática uma epistemologia que toma como base as mitologias e os saberes vinculados à culturas e identidades tradicionais - ainda que híbridas - que ocorrem na oralidade, caso das comunidades ciganas de Brasil e de Portugal? Serão elas tratadas como sujeitos? 
A experiência das pessoas ciganas com quem dialogamos e a minha como Kalon e pesquisador do tema diz que a resposta para essas questões é "não". Mas não é meu objetivo respondêlas ou chegar a uma verdade sobre elas. As destaco para confirmar que o pensamento circular e tautológico que só conhece como problemas aqueles que foram formulados cientificamente, é um dos gargalos centrais do saber acadêmico, que não reconhecendo nada além de si próprio, produz uma retroalimentação infinita, cega, injusta, exploratória, em uma palavra: "indolente" (Santos, 2002b).

Denominada por Santos (2002), de "Epistemologias do Norte", tal paradigma é um conjunto de métodos e também uma "política do conhecimento extremamente agressiva que amarra todos os outros conhecimentos que existiam nas zonas coloniais, por onde a experiência econômica de dominação se estendeu e procura destruir todos" (Santos e Meneses, 2009: 184). "Parecendo universal", o paradigma sociocultural moderno é "ocidental e provinciano" (Santos, 2002: 18) e produz uma visão de mundo nortecêntrica e eurocêntrica que é imposta às pessoas de outros lugares do mundo, especialmente as do Sul e do Oriente geopolítico.

Aqui nos aproximamos da categoria de geopolítica do conhecimento. Essa noção parte do princípio de que toda geopolítica se vincula a um modo de saber e é utilizada como aparato material da enunciação, garantindo legitimidade de dominação e opressão (Dussel, 2005). A geopolítica da divisão continental é chave para entender por que a Europa se elegeu como o ápice da civilização humana e centro do mundo (Mignolo, 2005: 18). E para compreender que a modernidade é um fenômeno constitutivo por relações assimétricas de poder produzidas na Europa e estendidas ao mundo; que combinou a ciência europeia, com a expansão imperialista/capitalista e implicou a subalternização das práticas e subjetividades de povos não-europeus (Idem: 16).

Cunhado por Anibal Quijano na década de 80, o conceito de colonialidade revela a perspectiva histórica dos marginalizados e desvenda que a modernidade e a colonialidade são duas caras de uma mesma moeda. A noção faz ver que os avanços da modernidade dependem de uma matriz colonial de poder, que reduziu povos indígenas a índios e africanos a negros (Mignolo, 2005: 32), bem como povos nômades a ciganos. Desse ponto de vista, é possível entender que o colonialismo/capitalismo requereu a construção do racismo, uma categorização específica da humanidade, a partir do locus de enunciação superior e privilegiado do homem-brancocristão-hetero-europeu imposta a povos não europeus, suas línguas, regiões, conhecimentos, países e continentes.

Raça e identidade racial foram estabelecidas como instrumentos de classificação social da população (Quijano, 2005). Além disso, o processo de modernidade/colonialidade aplicou uma 
perspectiva peculiar, dualista e binária do conhecimento: o eurocentrismo, que se tornou hegemônico no mesmo fluxo da expansão do domínio colonial da Europa sobre o mundo (Lander, 2005). A colonialidade epistemológica impôs uma repressão das formas de produção de conhecimento dos colonizados, seus universos simbólicos e padrões de produção de sentidos, de expressões e subjetivações (Mignolo, 2007: 121).

Ancorada na concepção renascentista de humanidade, a colonialidade do saber impõe a ideia de que modos de vida e organização sócio-cultural e conhecimentos de povos europeus como a ciência moderna ou a sua estética artística - seriam superiores aos estilos de vida e saberes filosóficos e aesthesicos de outros povos (Lander, 2005; Mignolo, 2010). O paradigma dominante não permite, por exemplo, trazer em uma investigação os discursos dos interlocutores da pesquisa de campo como dotados de saberes e narrativas que podem auxiliar na análise e na construção do objeto teórico. Desqualificadas, tais vozes são reconfiguradas como informações coletadas, servindo apenas para confirmar as hipóteses traçadas de antemão pelo pesquisador, ou submetendo-as a estratégias de estereotipação, as emudecendo, invisibilizando, ou transformando-as de sujeitos em objetos (Santos, 2002).

Ou seja, os cenários do universo cigano em Brasil e em Portugal, suas demandas, contextos e processos identitários, apesar de integrarem as realidades de ambas as nações há séculos, não estão dados pura e simplesmente na realidade histórico-social oficial de ambos os países. Essa temática encontra-se ausente dos estudos acadêmicos e negligenciada no campo da cidadania e dos direitos humanos (Silva, 2018; Magano, 2012). Por muito séculos, as comunidades ciganas - que somam em torno de 500 mil pessoas no Brasil (Seppir, 2008) e cerca de 40 A 60 mil em Portugal (ACIDI, 2013) ${ }^{9}$ - só ocuparam o interesse dos Estados brasileiro e português no sentido de implantação de políticas colonialistas anticiganas e a aplicação de estratégias violentas e persecutórias contra as pessoas dessas etnias (Silva, 2018, Moonen, 2011).

Algumas dessas questões foram apagadas pela ciência hegemônica e só emergiram nesse texto porque as articulamos numa proposta que tem como um de seus objetivos e ancoragens um diálogo entre as epistemologias ciganas, isto é, seus saberes e cosmovisões de mundo e a Ciência Social, via campo da Comunicação \& Saúde. Uma proposta de produção de conhecimento que não pode ser "lida" pela ciência convencional, mas se torna possível pela aplicação de um arranjo epistemológico multi-referencial que se ancorou em quatro matrizes teóricas, três delas científicas, porém, marginais: os estudos anticoloniais, os estudos culturais e os estudos

\footnotetext{
${ }^{9}$ Não há dados oficiais sobre o número de ciganos vivendo no Brasil e tampouco em Portugal, pois os censos populacionais dos dois países não fazem esta contagem. Os números apresentados são estimativas assumidas pelos próprios estados brasileiro e português, conforme contam nas referências citadas.
} 
semiológicos; e a filosofia cigana, considerada tão válida, quanto o modo de produção de saber acadêmico (Silva, 2018).

Os estudos anticoloniais subsidiaram os meus olhares sobre a desigualdade socioeconômica na crítica ao movimento de globalização e ao paradigma hegemônico da ciência moderna, que reforçam o colonialismo, o capitalismo e o patriarcado. Essas noções nos proporcionaram uma revisão no processo epistemológico da ciência moderna e a produção de conhecimento, que se fez de olhares teóricos, mas privilegiou os olhares epistemológicos da filosofia cigana como centrais.

Os modos de produção de conhecimentos da "Filosofia Cigana Kalon" se sustentam em narrativas e discursos mitológicos que povoam as memórias e histórias orais e se fazem presentes na estruturação de elementos culturais e simbólicos, portanto, comunicacionais, de grupos ciganos, que são postos em prática e ensinados de geração em geração a milênios. Elementos que ancoram modos de ver e viver a vida, isto é, suas formas de organização social e de estar no mundo, que subvertem e/ou resistem aos modos capitalistas e ocidentais de vida e sua ênfase no consumo e no descarte do ser humano, assumindo valores de solidariedade e amizade (Silva, 2018).

Considero que a produção social da kalonidade se estrutura como uma instância simbólica que é composta por três termos: a) uma filosofia de vida que contém e guarda as verdades últimas e basilares, que fundamenta os modos de olhar e ver a vidam, ao qual denominei como "Olhar ampliado de mundo"; b) um sistema de ação (que nomeei de "Lage no Mui” e de organização social (ao qual chamei de "Viver em Poesia"), este sim marcado por elementos e demarcadores culturais que, no conjunto, conformam múltiplas versões da cultura kalon, que denominei; c) permitindo às pessoas desta etnia recorrerem a ambos para basear seus sentimentos, comportamentos, gestos, ações, modos de 'estar-no-mundo', de ver, ser e viver, isto é, suas identidades culturais (Idem: 300).

Filosofia, sistemas de ação e organização sociocultural, no conjunto, conformam os modos de ser ou o seu sistema de identificação e diferenciação (identidades culturais).

A filosofia kalon e o seu sistema de ação e organização sociocultural são menos susceptíveis às influências externas e isso não quer dizer que sejam fixos. Enquanto a filosofia kalon guarda as verdades últimas e "valores básicos"; os sistemas de ação e de organização social são os responsáveis por colocá-las em prática e estruturar os modos de viver, ser, agir e se comportar dos kalon. As identidades culturais estão mais próximas da composição e do diálogo com o universo não cigano (Silva, 2018). 
O Olhar Ampliado de Mundo kalon é posto em prática por meio dos sistemas de ação, de organização e identificação sociocultural. E se constrói no confronto, por oposição ou hibridação aos valores da sociedade ocidental, tanto quanto as identidades e as culturas ciganas são negociadas e disputadas, internamente, dentro dos movimentos políticos ciganos e externamente, na influência que os Estados brasileiro e português veem colocando em prática junto às comunidades ciganas, principalmente, por meio do diálogo com seus movimentos sociais, ou relações interculturais na saúde.

Neste sentido, compreendo que a resistência contra a opressão e a dominação ao colonialismo e ao capitalismo se dá, fundamentalmente, por meio da manutenção das identidades ciganas e seus valores filosóficos, costumes e tradições, que possuem um outro modo de olhar a vida e de viver. O principal contraste são os valores atribuídos aos seres humanos e ao material. A visão da filosofia kalon coloca o ser humano à frente do dinheiro e dos bens materiais, ao oposto da modernidade capitalista, que não consegue ver o mundo noutra ótica que não a material, até permitindo variações, mas sempre e desde que elas se enquadrem no seu modus operandi em que o financeiro vem sempre primeiro, inclusive, que as pessoas.

Neste cenário epistemológico conflituoso e de distintos saberes, um dos maiores desafios de um pesquisador do universo cigano é manter o foco no direito das pessoas romani de se auto representarem e falarem por si mesmas e não na agência e no papel de pesquisador, que já possui uma voz ativa fortalecida por uma gama de vozes e correntes teóricas legitimadas academicamente. Isso não significa ignorar as vozes oficiais, apenas as deslocar de sua habitual centralidade, conferindo esta prerrogativa às vozes ciganas, que nos contextos históricos têm sido marginalizadas ou excluídas.

Elaborar e refletir sobre tais questões em uma investigação nos permite uma atitude autocrítica, que se pauta em todos os momentos pelo cuidado de não causar qualquer "violência epistêmica" ou simbólica, o que, ao contrário da emancipação e inclusão social, pode contribuir para manter os ciganos como sujeitos silenciados e censurados, ou na melhor das hipóteses, estereotipados. É preciso, enquanto pesquisador do universo cigano, estar muito atento para não cair neste equívoco e continuar a produção de um saber colonizado, eurocêntrico e anticigano.

Neste sentido, aplicamos uma ecologia de saberes (Santos, 2010) para não canabalização ou extrativismo de saberes das comunidades ciganas, que se encontram em situação de desigualdades e exclusão. Outra corrente que teve papel fundamental para pensar as relações entre o universo cigano, por meio de seu movimento social e a teoria, foram os Estudos Culturais. É o que veremos a seguir. 


\section{Os estudos culturais como lugar de luta anticolonial: a relação entre a teoria e a polí- tica}

Toda essa discussão, que envolve a relação entre a teoria e o ativismo, ou seja, a relação entre pesquisadores e grupos periféricos pesquisados, também é tratada pelos Estudos Culturais (EC), especialmente, a corrente latino-americana a qual nos filiamos. No trabalho que desenvolvi no doutorado, já citado no tópico introdutório (Silva, 2018) essa matriz foi fundamental para construir um diálogo com os movimentos sociais ciganos e fazer emergir as pautas e agendas políticas no âmbito da comunicação, da saúde, dos direitos humanos e da cidadania, como um todo.

Nossa visão é a dos EC como um lugar de luta anticolonial e vai ao encontro de qualificações que os aplicam como "campo de pesquisa, prática metodológica, viés epistemológico, movimento e rede (Johnson), política cultural dos novos movimentos sociais (Jameson), campo interdisciplinar onde certas preocupações e métodos convergem (Turner)" (Araujo, 2002: 67). Como coloca Bhabha (1998: 245), a posição enunciativa dos EC "tenta institucionalizar uma série de discursos transgressores cujas estratégias são elaboradas em torno de lugares de representação não equivalentes".

Refletindo sobre as ligações entre a teoria e o ativismo, Homi Bhabha reforça a crítica à equação conhecimento-poder. $\mathrm{O}$ autor critica os binarismos em torno desta relação e propõe uma outra forma de olhar para a relação entre a teoria e a política. Em suas palavras, "é um sinal de maturidade política aceitar que haja muitas formas de escrita política cujos diferentes efeitos são obscurecidos quando se distingue entre o 'teórico' e o 'ativista'” (Bhabha, 2005: 4647). E exemplifica o que diz destacando que as relações entre ambos e seus produtos são entrecruzadas.

Por exemplo, "o panfleto utilizado na organização de uma greve seja pobre em teoria, ao passo que um artigo especulativo sobre a teoria da ideologia deva ter mais exemplos ou aplicações práticas". Nesta perspectiva, tanto o panfleto, quanto o artigo, são "formas de discurso e nessa medida produzem, mais do que refletem, seus objetos de referência". A diferença entre eles está em suas qualidades operacionais e no modo como um subsidia o outro. "Eles existem lado a lado - um tornando o outro possível - como a frente e o verso de uma folha de papel" (Bhabha, 2005: 46-47).

O problema, segundo Bhabha, é que o lugar da diferença cultural e, por conseguinte, da identidade, "acaba se tornando em uma estratégia de contenção do outro", em que este outro é citado, mencionado, emoldurado, iluminado, encaixado, mas nunca é o agente ativo da circu- 
lação (Idem: 59). "O outro perde seu poder de significar, de negar, de iniciar seu desejo histórico, de estabelecer seu próprio discurso, institucional e oposicional”. Diante deste cenário, o autor também questiona o papel da teoria ocidental:

Serão os interesses da teoria ocidental necessariamente coniventes com o papel hegemônico do ocidente como bloco de poder? Não passará a linguagem da teoria de mais uma estratégia da elite ocidental culturalmente privilegiada para produzir um Discurso Outro que reforça sua própria equação de conhecimento-poder?

(Bhabha, 2005: 46)

É neste sentido, que algumas análises veem os Estudos Culturais como um posicionamento teórico, intelectual e político (Martino, 2012). E há uma certa concordância em dois pontos: a) sua natureza de projeto simultaneamente teórico e político e b) ter a cultura como área de atuação (Araujo, 2002). Sobre o projeto político, para além de estudar as relações de poder na sociedade, os estudos culturais estão implicados nelas, integrando o circuito que buscam analisar. Autores "tendem a assumir o compromisso de agir diretamente nas práticas políticas, sociais e culturais, que são o objeto de sua abordagem", configurando a produção de um conhecimento ligado à um projeto de ação (Idem: 68). Como no meu caso em que busquei no trabalho de doutorado efetivar um projeto de intervenção na realidade da saúde cigana, denunciando problemáticas, como o racismo institucionalizado contra essas etnias (Silva, 2018).

Outra contribuição é a compreensão da cultura como uma prática cotidiana, que, produzida materialmente, se liga à própria identidade dos grupos sociais (Martino, 2012, p. 96), inclusive aqueles que historicamente foram subalternizados e inferiorizados, que na visão moderna são considerados sem cultura ou, no máximo, como uma cultura primitiva, a exemplo de ciganos, indígenas ou os camponeses africanos. Ao fazerem uma associação entre as formas culturais de poder às suas condições sociais de possibilidades (produção, circulação e consumo), os EC contribuem para compreendermos as lutas de poder que se dão na ciência. Ajudam a revelar os discursos científicos como espaços de disputas de poder, que não são neutros, expressam a defesa dos interesses das elites e dos modelos e paradigmas hegemônicos de dominação, contribuindo para o fortalecimento das desigualdades política, cultural, social, política e das negligências no campo da comunicação e saúde (Araujo, 2002: 68).

Os EC permitem enfocar criticamente o contexto político e epistemológico do universo cigano, inclusive do ponto de vista da comunicação, da saúde e da cidadania. E dá a condição para expressar os interesses em jogo, inclusive os meus próprios, deixando explícita a posição e o lado em que estamos: o lado dos ciganos. Nessa dupla função, teórico e política, os EC 
dialogam com os estudos decoloniais, auxiliando na produção de um conhecimento crítico, vinculando-o a um projeto de atuação.

E contribuem para, utilizando uma expressão de Santos (2002), a produção de conhecimento-emancipação que se cria na perspectiva de uma luta anticolonial, por cidadania e inclusão das comunidades ciganas, questões estas que não podem deixar de ser analisadas pelo viés intercultural, da identidade e da diferença. Assim, nos distanciamos da antropologia clássica, cujo propósito central de seus praticantes era o de "assumir inteiramente o ponto de vista interno da cultura elegida" (Canclini, 2004: 20) ou falar pelos pesquisados (Spivaki, 2010), transformando os sujeitos de pesquisa em representações objetificadas (Santos, 2002).

Nesta visão, o que é "teoricamente inovador e politicamente crucial é a necessidade de passar além das narrativas de subjetividades originárias e iniciais e de focalizar aqueles momentos ou processos que são produzidos na articulação de diferenças" (Bhabha, 1998: 20). Ou seja, os termos do embate cultural são produzidos de maneira política. A articulação social da diferença desde uma perspectiva da minoria "é uma negociação complexa, em andamento, que procura conferir autoridade aos hibridismos culturais que emergem em momentos de transformação histórica" (Idem: 20-21). E, é neste contexto teórico-político, que situamos a questão em torno das culturas ciganas que buscam hoje exatamente realizar a afirmação de suas identidades, ao mesmo tempo em que procuram denunciar as opressões, além de fazer emergir silenciamentos e invisibilidades históricas.

\section{Outros contextos e novas demandas cidadãs: nas considerações finais, a emergência das vozes ciganas no diálogo com a ciência}

Vimos que os autores dos EC têm debatido algumas questões comuns como a produção e reprodução dos sentidos sociais, pensando-as como parte de um circuito cultural, no qual o tema da constituição das próprias identidades é parte integrante. Esta visão possui uma estreita correlação com o campo discursivo e a manutenção ou transformação das desigualdades e da exclusão social. A perspectiva dos EC atrela os estudos de cultura e das relações interculturais à uma dimensão de luta política.

Diz Bhabha (2005: 163) que "não há uma simples transformação do conteúdo das ideias políticas. O próprio lugar de onde o político é falado - a esfera pública mesmo, torna-se uma experiência de liminaridade". Assim, "o efeito do poder colonial é percebido como o produto de hibridização". A problemática se instaura nas questões de "representação e de individuação colonial", que podem ser revertidas por meio "da recusa colonialista" operada quando "saberes 
negados se infiltram no discurso dominante e tornam estranha a base de sua autoridade" (Idem: 165).

Enquanto pesquisador e militante do universo cigano, a teoria da hibridação possibilita "perceber com mais clareza um leque de práticas estratégicas discursivas, que sem ele apareceriam como ambiguidade, ou adesismo" (Araujo, 2002: 75). Torna possível compreendermos, como e por que as pessoas romani operam, nas relações com as sociedades que os envolvem, isto é, no campo discursivo do outro.

$\mathrm{Na}$ área acadêmica, ou em qualquer outra área estatal, midiática e no senso comum, nós ciganos somos chamados a desenvolver nossas falas e táticas num espaço de imagens construídas pelos não ciganos e ao qual devemos corresponder minimamente se quisermos negociar até mesmo questões como a nossa própria identidade cultural, ou a colocação em prática do simples direito de organização social. O discurso do movimento político cigano e mesmo das comunidades ciganas e, consequentemente, as identidades sociais, culturais e políticas dos grupos que o veiculam, é na maior parte das vezes, construído no campo de força e categorias dos interlocutores que são detentores de maior capital simbólico, neste caso, os pesquisadores, a ciência e o imaginário ocidental.

As pessoas ligadas ao movimento cigano rearticulam fundamentos de sua filosofia e sabedorias que a tradição das etnias e grupos romani oferecem; com os parâmetros discursivos que lhes são impostos, como nos processos de associativismo exigidos para o diálogo institucional com os órgãos do estado. Ou na participação marcada e pouco representativa de elaboração de políticas públicas. Ademais, do ponto de vista da produção social dos sentidos, historicamente os grupos romani sempre receberam nomeações e classificações que foram atribuídas pelos não ciganos, que tinham e têm essa necessidade para exercer controle sobre essas comunidades (Silva, 2018; Silva e Araujo, 2015). São denominações de estrutura interna e organização social, do espaço social e geográfico que ocupam, baseado principalmente no mito do nomadismo.

Há todo um sistema de denominações não cigano - nos hospitais, nas feiras, nos comércios ou nas instituições públicas -, que conferem uma feição identitária estigmatizada, estereotipada e racista aos membros dessas comunidades com o objetivo de homogeneizar, neutralizando diferenciações internas. Tomando por base os preceitos dos EC, é possível "desnaturalizar" dispositivos de enunciação, como os processos de identificação e diferenciação (nomeação), fundamentais para a constituição das identidades individuais e coletivas, incluindo aquelas de resistência, como as ciganas.

Imbuído desta ancoragem, compreendo que a identidade genérica "cigana", possui duas faces que perpassam fortemente o senso comum, a visão midiática e a ciência tradicional, ora 
numa visão negativa e inferiorizante, com adjetivos como ladrões, trambiqueiros, vagabundos, subversivos, perigosos; e ora numa visão romântica, idealizada, irreal; ambas visões rasas e equivocadas, mas que foram forjadas de maneira racista em processos de identificação/diferenciação posto em jogo pelas sociedades ocidentais, especialmente, a partir de estereotipação e discriminação operadas pelos sistemas de representação e nomeação. Como resultado, temos uma situação nefasta, que reproduz e amplia o racismo, a exclusão e as desigualdades sociais em que a maioria das comunidades ciganas se encontra hoje (Silva, 2018).

Outro exemplo, são as maneiras com as pessoas ciganas, inclusive eu, manejam as próprias identidades culturais, que ora se afirmam em contraste aos não ciganos e ora miméticas, no processo de hibridação (Bhabha, 2005). "Nas relações interétnicas fica patente o uso da identidade como estratégia política" (Araujo, 2002: 77). E surge nesse cenário como uma estratégia de luta dos que estão historicamente em desvantagem na distribuição dos poderes, por um maior equilíbrio nessas regras (Idem: 78). Entre as diferentes etnias romani, por exemplo, a construção de suas identidades e culturas, não seguem um processo homogêneo. Não há uma essência cigana, mas sim múltiplas identidades, com distintos grupos, subgrupos, que variam conforme a região e o país onde se movimentam (Silva, 2018; Silva, 2009).

Por outro lado, os estudos anticoloniais, revelam a contínua luta simbólica ocorrida nos campos porosos da cultura e da comunicação, ligados umbilicalmente. Campos que se entrelaçam às dimensões sociais, econômicas e políticas, conformando um intrincado de maneiras de ver e de pensar o papel que a informação adquiriu em tempos de "pós-colonialismo". E, cujo comando hegemônico, está atrelado aos sistemas eletrônicos e virtuais desenvolvidos pelo poderio econômico do capitalismo global, que se ancora na ideologia neoliberal "da mão livre" do mercado, colocando os Estados-nações, seus sistemas políticos e governos de joelhos para atender às suas ambições expansivas na busca do lucro infinito (Bauman, 1997).

Os autores anticoloniais auxiliam a pensar uma relação entre pesquisadores e pesquisados do universo cigano, na compreensão crítica de dinâmicas dos processos sociais e políticos em tempos de globalização neoliberal. Em outras palavras, a teoria decolonial (Quijano, 2005; Mignolo, 2007) nos mostra que mais do que enquadrar numa teoria ou fórmula de contato exploratória, "extrativista" (Santos, 2017)10; precisamos olhar com cuidado para os modos de agir e proceder com os interlocutores da pesquisa de campo (praxiológica).

Especialmente quando trabalhamos com populações vítimas do colonialismo e do capitalismo - com as comunidades ciganas -, que afinal, são as mais interessadas neste conhecimento,

\footnotetext{
${ }^{10}$ Aula Magistral 3, “A Sociologia Pós-Abissal: Metodologias Não Extractivistas”, Auditório da Faculdade de Economia da Universidade de Coimbra.
} 
garantindo a sua apropriação em favor de um fortalecimento de suas lutas. Neste cenário, a produção de um saber crítico no campo dos estudos ciganos em favor das próprias pessoas romani, tem de, necessariamente, passar por uma epistemologia dialógica e coparticipativa, que privilegia a horizontalidade entre saberes e interlocutores da pesquisa, independente se são os que propuseram o estudo, ou aqueles que são os sujeitos da realidade em questão problematizada. Deve observar uma proximidade com a vida cotidiana e vivida e ter familiaridade com a mudança e a justiça social.

Mais do que refletir sobre os modos de ver e analisar (teorias e metodologias) os temas estudados, é necessário deixar claro o envolvimento, os modos de agir do pesquisador e da política de conhecimento utilizada na produção deste saber, explicitando a articulação entre as vozes da pesquisa. Pensar nessa perspectiva permite o encontro e a aproximação com as pessoas ciganas, bem como a construção de um diálogo baseado na lealdade, no respeito e na confiança mútuas, o que proporciona produzir um conhecimento de fato coletivo e dialógico com as pessoas ciganas e não sobre ou para os ciganos, como tem acontecido na maior parte dos estudos referentes à tais comunidades. 


\section{Bibliografia}

ACIDI (2013). (Alto Comissariado para Imigração e Diálogo Intercultural). Estratégia Nacional para Integração das Comunidades Ciganas: 2013-2020.

Araujo, I. S. (2000). A Reconversão do Olhar. Série Acadêmica. São Leopoldo: Editora Unisinos.

Araujo, I. S. (2002). Mercado Simbólico: interlocução, luta, poder - um modelo de comunicação para políticas públicas. 2002. Tese (Doutorado). Escola de Comunicação, Universidade Federal do Rio de Janeiro, Rio de Janeiro.

Barbero, J. M. (1997). Dos meios às mediações: comunicação, cultura e hegemonia. Trad. Polito, R. E Alcides, S. Rio de Janeiro: Editora UFRJ.

Bauman, Z. (1998). O mal-estar da pós-modernidade. Rio de Janeiro: Jorge Zahar Ed.

Bhabha, H. K. (1998). O Local da Cultura. Belo Horizonte: Editora da UFMG.

Bhabha, H. K. (2005). O Local da Cultura. Belo Horizonte: Editora da UFMG.

Bhabha, H. K. (2010). Nación y Narración: entre la ilusión de una identidad y las diferencias culturales. Buenos Aires: Siglo Veintiuno Editores Argentina S.A.

Canclini, N. G. (2004). Diferentes, Desiguales y Desconectados: Mapas de la Interculturalidad. Barcelona: Editorial Gedisa, S.A.

Canclini, N. G. (1997). Culturas Híbridas - estratégias para entrar e sair da modernidade. Tradução de Ana Regina Lessa e Heloísa Pezza Cintrão. São Paulo: EDUSP, 283-350.

Dussel, E. (2005). Europa, modernidade e eurocentrismo. In: LANDER, E. Colonialismo; Modernidad; Capitalismo; Poder Político; Sociedad; História; Eurocentrismo; America Latina. CLACSO, Consejo Latinoamericano de Ciencias Sociales, Buenos Aires.

Lander, E. (org) (2005). A colonialidade do saber: eurocentrismo e ciências sociais. Perspectivas latinoamericanas. Coleccin Sur Sur, CLACSO, Ciudad Autnoma de Buenos Aires, Argentina.

Quijano, A. (2005). Colonialidade do poder, Eurocentrismo e América Latina. In: Lander, E. Colonialismo; Modernidad; Capitalismo; Poder Político; Sociedad; História; Eurocentrismo; America Latina. CLACSO, Consejo Latinoamericano de Ciencias Sociales, Buenos Aires.

Hall, S. (2003)A Identidade Cultural na Pós-Modernidade. Rio de Janeiro: DP\&A.

Maldonado-Torres, N. (2008). A topologia do Ser e a geopolítica do conhecimento. Modernidade, império e colonialidade. Revista Crítica de Ciências Sociais [Online], 80 | 2008, colocado online no dia 01 Outubro 2012, criado a 28 Março 2017. URL : http://rccs.revues.org/695.

Magano, O. (2012). Pluralidade e reconfiguração da identidade cigana em Portugal. Sociologia, Revista da Faculdade de Letras da Universidade do Porto, Vol. XXIII, pp. 251-268. 
Martino, L. M. S. (2012). A área dos Estudos Culturais: consenso genealógico e indefinição epistemológica. Comunicação \& Sociedade. Ano 33, n. 57, 79-101, jan./jun.

Mignolo, W. D. (2005). A colonialidade de cabo a rabo: o hemisfério ocidental no horizonte conceitual da modernidade. In: Lander, E. Colonialismo; Modernidad; Capitalismo; Poder Político; Sociedad; História; Eurocentrismo; America Latina. CLACSO, Consejo Latinoamericano de Ciencias Sociales, Buenos Aires.

Mignolo, W. D. (2007). La Idea de America Latina. Barcelona, Gedisa Editorial: primeira edição.

Mignolo, W. D. (2010). Aiesthesis Decolonial. Calle 14. V. 4, nº 4 . Enero-junio 2010, 10-25.

Moonen, F. (2011). Anticiganismo: Os ciganos na Europa e no Brasil. Recife, PE:

Disponível em: http://www.dhnet.org.br/direitos/sos/ciganos/a_pdf/1_fmanticiganismo 2011.pdf

Santos, B. S. (2016). Para uma nova visão da Europa aprender com o Sul. Sociologias, ano $18, n^{\circ} 43$, set/dez, 24-56.

Santos, B. S. (2002). Para um novo senso comum: a ciência, o direito e a política na transição paradigmática. 4a. São Paulo: Ed. Cortez.

Santos, B. S. (2002b). Para uma Sociologia das Ausências e uma Sociologia das Emergências. Revista Crítica de Ciências Sociais, 63, outubro, 237-280.

Santos, B. S. \& Meneses, M. P. (2009). Epistemologias do Sul. Coimbra: Almedina, 2009.

Santos, B.S. (2010). Para além do pensamento abissal: das linhas globais a uma ecologia de saberes. In: Santos B.S \& Meneses M.P. (org). Epistemologias do Sul. São Paulo: Cortez, 31-83.

SEPPIR - Secretaria de Políticas de Promoção da Igualdade Racial. Brasil Cigano: Guia de Políticas Públicas para povos ciganos. Brasília, 2013. Disponível em: < http://www.seppir.gov.br/.arquivos/guia-de-politicas-publicas-para-povos-ciganos> Acesso em 21 Set. 2008.

Silva, A. A. J. (2009). “A liberdade na aprendizagem ambiental cigana dos mitos e ritos Kalon”, Dissertação (Mestrado) - Programa de Pós-Graduação e Educação, Universidade Federal de Mato Grosso, Cuiabá-MT, 2009.

Silva, A. A. J. (2018). Produção Social de Sentidos em Processos Interculturais de Comunicação e Saúde: a apropriação das políticas públicas de saúde para ciganos no Brasil e em Portugal. (Doutorado) - Programa de Pós-Graduação em Informação e Comunicação em Saúde, Instituto de Comunicação e Informação Científica e Tecnológica em Saúde, Fundação Oswaldo Cruz.

Silva, A. A. J. \& Araujo, I. S. (2015). Vigilância, controle e políticas públicas de saúde para ciganos: reflexões sobre desigualdade e exclusão. In: Colóquio semiótica das mídias, Vol. 6, 1, 2015. Jarapatinga (AL): Centro Internacional de Comunicação e Semiótica. UFAL. Disponível em: <http://ciseco.org.br/anaisdocoloquio/index.php/edicao-atual/187-acoesentre-atores-analise-sobre-formas-de-interacao-online-em-uma-pagina-oficial-de-umainstituicao-de-ensino-26>. 
Spivak, G. C. (2010). Pode o Subalterno Falar. Trad. Almeida, S. R. G.; Feitosa, M. P.; \& Feitosa, A. P. Belo Horizonte: Editora da UFMG. 



\section{PARTE II \\ CIGANOS, PERCURSOS ESCOLARES E LITERACIA}





\title{
Capítulo 5.
}

\section{Imaginarios divergentes, caminos convergentes. La importancia de una nueva didáctica de las ciencias sociales en un contexto educativo con vulnerabilidad social de la ciudad de Huelva (España). Una aproximación antropológica}

\author{
JUAN CARLOS ROMERO VILLADÓNIGA ${ }^{\mathbf{1}}$ \\ Departamento de Didácticas Integradas. Facultad de Educación. Universidad de Huelva. \\ juancarlos.romero@ddi.uhu.es
}

Resumen: La institución escolar, en su papel enculturador de la sociedad hegemónica, presenta discursos y lógicas las cuales no siempre se corresponden con las prácticas puestas en juego. Medidas como la inclusividad de colectivos vulnerables a partir de situaciones tan variadas como su composición étnica, origen social y económico encierran, en ocasiones, políticas ocultas de segregación y/o guetización de forma no intencional. El presente trabajo gira alrededor de las violencias que se producen sobre el alumnado de una comunidad gitana ubicada en una barriada periférica de la ciudad de Huelva, haciendo ver cómo las asimetrías frente a la sociedad hegemónica reproducen unas condiciones de partida muy desfavorables. Del mismo modo, como fórmula alternativa, se expone la importancia que va a tener una nueva concepción pedagógica puesta en marcha en el centro objeto de investigación donde, a partir de una reconceptualización de las capacidades didácticas de las Ciencias Sociales, se procurará un acercamiento entre imaginarios divergentes a través del aprendizaje servicio como estrategia de intervención.

Palabras clave: Imaginario, violencia, interseccionalidad, aprendizaje servicio, complejidad.

\footnotetext{
Abstract: The educational institution playing its role of culturalizing the hegemonic society shows discourse, perspective and logic in such a way that do not correspond to the practices

${ }^{1}$ Juan Carlos Romero Villadóniga é Máster en Patrimonio Histórico y Doctor en Humanidades por la UHU, Máster en Antropología Aplicada y Doctor en Filosofía, especialidad Antropología Filosófica, por la UCLM y actualmente doctorando en Didácticas Integradas por la Universidad de Huelva. Se encuentra realizando una investigación doctoral acerca de las implicaciones que tiene el estigma social en las corporeidades en colectivos vulnerables de la provincia de Huelva en el plano educativo. Cuenta con 54 artículos publicados y/o en prensa, referentes muchos de ellos a la importancia de los sentimientos como forma de abordar la complejidad humana, así como a la producción de violencias educativas desde la sociedad hegemónica y los procesos que se generan desde las culturas de resistencia. Institución: Departamento de Didácticas Integradas. Facultad de Educación. Universidad de Huelva.Juancarlos.romero@ddi.uhu.es; jucarovi66@gmail.com.
} 
and methodologies developed. Measures such as the inclusiveness of vulnerable groups due to a variety of situations such as their ethnic composition, social or economic origin sometimes involve hidden policies of segregation and/or guettoization unintentionally.

The present paper focuses on the violence suffered by those students belonging to a gipsy community who live in slum dwellings located in the outskirts of Huelva, making clear that the existing asymmetries against the hegemonic society perpetuate highly disadvantageous starting conditions. Similarly, as an alternative proposal, the relevance of a new pedagogical approach developed in the educational centre where the research is carried out is analyzed, bearing in mind a reconceptualization of the potential impact of social sciences in order to bring closer divergent social imaginaries through the promotion of service-learning as an intervention strategy.

Keywords: Imaginary, violence, intersectionality, service learning, complexity.

\section{Un difícil punto de partida}

Intentar exponer el fenómeno de la génesis y construcción de la violencia escolar, resulta ser una tarea nada fácil. A pesar de la existencia de innumerables informes y estudios temáticos llevados a cabo en el seno de esta institución (Defensor del Pueblo 2000 y 2007; Informe Ayerbe, 2002; ICEC, 2005; Informe Cisneros X, 2007; OECE, 2010), la performatividad que adquiere en cuanto a modalidades y actores hace que, en poco tiempo, la obsolescencia de la investigación quede al descubierto.

Y qué decir cuando entran en juego dimensiones tan diferentes y diferenciadoras como puede ser la vulnerabilidad social, la etnia, el género o el lugar de residencia. A modo de corolario, todas estas dimensiones se interseccionan dotando de una mayor complejidad al fenómeno.

Por esta razón, toda aproximación que se quiera hacer al fenómeno de la producción de violencias debería tener en cuenta, como punto inicial, la complejidad que tendrá no sólo en lo referente a tipologías, siendo también en lo referido a escenarios, escenas, actores y dimensiones interpersonales puestas en juego (Romero-Villadóniga, 2019).

Este difícil punto de partida plantea, desde sus inicios, una gran interrogante. ¿Existe algún paradigma o teoría que pueda ayudarnos por los derroteros de tanto marasmo interseccional? Por desgracia, no hay una respuesta definitiva a ello. Sin embargo, para el caso que nos ocupa, será el paradigma de la complejidad de Morin $(1986 ; 2004)$ el que nos oriente y nos guíe en todo el proceso. Y es que a través de una visión compleja, abierta e interaccional de todos los elementos presentes en cualquier escena de violencia, será como lograremos una aproximación 
al problema. Para ello partiremos de la necesidad de contemplar al sujeto-individuo como un ser complejo compuesto por tres grandes dimensiones: el auto-ego-centrismo, la ego-autoreferencia y la ego-auto-finalidad (Solana, 2000). Por medio de la primera el ser humano pasa a ser el centro de todo su mundo vivido/sentido/percibido, acogiendo o regulando al otro por medio de su capacidad de elección y su ideoneidad en su visión cosmoespacial. Ello hace que se convierta en el eje trascendente de su existencia, considerándose por encima del resto en cuanto él mismo es el constituyente primordial de su mundo. Pero para poder consolidar esa posición, el sujeto debe recurrir a procesos de autoreferencia constante, sometiendo los datos objetivos a un constante proceso de computación y análisis para reforzamiento del YO, la cual permitirá alcanzar unas auto-ego-finalidades.

Este sujeto, en su complejidad, actuará e interactuará tanto en sí mismo como frente a la alteridad en medio de un entramado complejo de elementos, los cuales tendrán una estrecha interdependencia entre sí, en un continuo juego de equilibrio/desequilibrio de sus partes. De esta forma, el sujeto inscribirá sus cotidianeidades dentro de un sistema familiar, inscrito a su vez, en otros próximo donde se mezclarán elementos de socialización primaria y secundaria (sistema barrio).

En este marasmo, la institución educativa no permanecerá ajena a este nivel de complejización. Al igual que en el sistema barrio, el familiar o el inherente al propio sujeto, la institución se conformará a partir de la interacción de varios subsistemas, los cuales se complementarán así como actuarán en una dialógica constante, haciendo que entre en continuos momentos de entropía/neguentropía entre todas sus partes. Así, podemos distinguir cinco grandes subsistemas conformadores, los cuales van a tener unos roles y funciones muy concretas (RomeroVilladóniga, 2019):

- Subsistema organizativo. Parte fundamental en el sistema, será el entramado encargado de la organización, control y vigilancia de cuantos actores intervengan en las diferentes escenas dentro y fuera del aula. La organización de los espacios, la aplicación normativa, la vigilancia de control de los procesos puestos en marcha, y un larguísimo etcétera, compondrán sus funciones primordiales.

- Subsistema pedagógico. Motor ideológico sobre el cual se sustenta la praxis, el subsistema se configurará a partir del imaginario social dominante, así como de las diferentes concepciones pedagógicas indicadas desde el poder. Su importancia resultará vital, pues será uno de los ejes vertebradores a partir de los cuales se dotará de lógica a todas las esferas presentes en la acción educativa. 
- Subsistema Curricular. Vertebrador de la práctica docente, tiene un carácter eminentemente propedéutico, organizando, clasificando y jerarquizando todas las prácticas contenidas en el sistema.

- Subsistema didáctico. Como forma de acercamiento entre lo que el sistema ofrece y las necesidades del alumnado. De gran importancia frente al resto de los subsistemas operables, resulta clave a la hora del acercamiento/alejamiento entre imaginarios sociales y prácticas puestas en juego.

- Subsistema relacional. Verdadero articulador del resto, al encontrarse de forma interseccional entre todos. Vertebrará las relaciones interpersonales que se darán dentro y fuera de la institución.

Todos estos subsistemas interactuarán entre sí, al tiempo que interaccionarán con otros provenientes de otros sistemas externos, tales como el sistema barrio o el familiar. Por todo ello, como se puede comprobar, no se puede hablar del fenómeno de la violencia en sentido restrictivo, sino que trasciende de lo meramente visible para adentrarse en tramas ocultas de significación (Capra, 2003), convirtiéndose en un elemento articulador presente en y entre cada uno de los sistemas que operan en/desde el sujeto complejo. Va mutando y adoptando nuevas formas a medida que hacen acto de presencia, de ahí su carácter performativo y multidimensional.

Llegados a este punto cabría la pena reformular el concepto en sí. ¿Resulta ser un fenómeno aislado que se puede componer, a modo de puzle, a través de la suma de sus partes? o bien ¿puede ser entendido sin la multidimensionalidad y la diversidad de sistemas y subsistemas que operan en él?. La respuesta no resulta ser nada sencilla. Quizás la clave resida en, como expone Bourgois:

Llamar la atención sobre ellas como productos y mecanismos de la dominación discursiva y física y de la desigualdad, es subrayar las bases para unas formas punitivas de gubernamentalidad en la era neoliberal que han llegado a ser cada vez más aceptadas como legítimas por las víctimas como por los perpetradores (Bourgois, 2004: 30)

\section{Un escenario de investigación complejo}

La barriada Diego Sayago, más comúnmente conocida en la ciudad de Huelva como barriada del "Torrejón", se ubicó hasta no hace mucho, en una zona periférica alejada del resto de la ciudad. Comunicada por una pequeña carretera, alojó en sus orígenes a población de etnia gitana, principalmente, desplazada por la expansión industrial de los años 70. Familias, hasta 
entonces ubicadas en zonas de marisma, dedicadas a labores de trabajo en salinas artesanales, o de la extracción de recursos próximos, serán de la noche a la mañana, realojadas forzosamente en bloques de pisos contiguos en una barriada caracterizada por la casi ausencia de servicios mínimos.

Desde sus orígenes, la barriada tendrá una significación negativa. Asociada a la venta de chatarra, o el tráfico de drogas, la desestructuración de las lógicas y prácticas que habían dado sentido a la comunidad generarán un progresivo fenómeno de aculturación, mezclándose elementos propios con los de la cultura hegemónica. El anterior equilibrio interfamiliar se romperá, perdiendo progresivamente autoridad los "titos", llamados erróneamente por la cultura gachó como patriarcas.

Figura 1. Ubicación de la barriada Diego Sayago en el contexto de la ciudad de Huelva. Fuente: Google Maps.

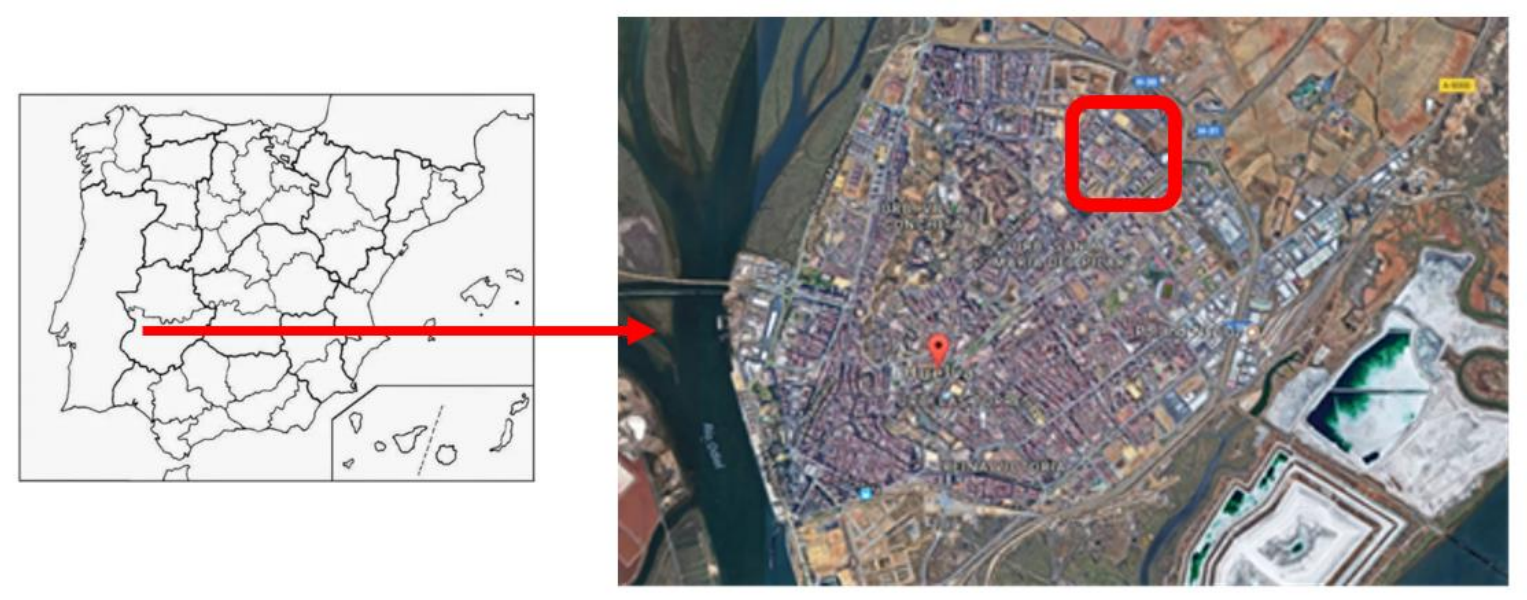

Esta progresiva destrucción de la cultura de origen, así como la introducción masiva de droga en la ciudad de Huelva a finales de los años 70-80, provocará la lucha por el control de su tráfico por parte de determinados clanes familiares, los cuales emplearán la barriada como centro de operaciones. Ello provocará una memorialización del lugar asociada al conflicto y la violencia, agravando con ello, la estigmatización de sus habitantes. Se creará entonces una particular apreciación simbólica del espacio, dando lugar a lo que Biassatty y Company denominan "lugares sujetos", espacios los cuales

[...] No solamente utilizan trazas materiales donde aferrarse sino, además, memorias elaboradas por sujetos que las acarrean y las comparten, les dan forma y las disputan, les agregan matices, música, colores y palabras, les prestan contexto social e histórico, las recrean a través de distintas prácticas colectivas, etc.

(Biassatty y Compañy, 2015: 24). 
La consecuencia más inmediata será la estigmatización del espacio, afectando también a sus habitantes, los cuales experienciarán un continuo proceso de exclusión social. Como apunta Bordieu:

El barrio estigmatizado degrada simbólicamente a quienes lo habitan, los cuales, a cambio, hacen lo mismo con él, ya que al estar privados de todas las cartas de triunfo necesarias para participar en los diferentes juegos sociales, no comparten con él sino su común excomunión

(Bourdieu, 1999: 126)

Esta situación de partida se mantendrá hasta, prácticamente, finales del siglo XX. La construcción de un hospital en sus inmediaciones, así como la expansión urbana de la ciudad hacia el interior, permitirá una integración de la barriada en el contexto urbano de la ciudad. Será entonces cuando la pequeña carretera de acceso se convierta en una avenida, permitiendo una fluida comunicación de la barriada con el resto del entorno. Sin embargo, las memorializaciones en la zona, así como las vivenciaciones puestas en juego no se modificarán sustancialmente.

Actualmente, a pesar de las mejoras introducidas, la barriada presenta un perfil de "alto riesgo de exclusión social" (Distrito V, 2016), pudiendo hablarse de un "enclave de riesgo" (Ávila y García, 2015). Con elevadas tasas de desempleo, siendo prácticamente total en población en edad joven, una carencia de espacios comerciales, una abundancia de infraviviendas y elevada conflictividad social, la barriada presenta graves problemas.

La precariedad vital alcanza a un porcentaje elevado de población, presentando un $20 \%$ situación de pobreza extrema, ampliándose hasta el $65 \%$ la población con síntomas graves de vulnerabilidad social o con riesgo real de exclusión. La práctica totalidad de las familias de la barriada presenta situaciones complejas, necesitando de la intervención constante de los servicios sociales municipales y/o de asociaciones que operarán en la zona, así como de las redes de solidaridad familiar.

Esta precarización de la barriada tendrá su reflejo en el único IES (Instituto de Educación Secundaria) público que operará en la zona, el IES La Marisma. Con un alumnado compuesto en su mayoría por etnia gitana $(80 \%)$, desarrollará su convivencia diaria entre los problemas sociales y personales que se generarán, en la mayoría de las ocasiones, en el ámbito familiar o del barrio. Intersecionado por elementos como su composición étnica, su vulnerabilidad social, el lugar de procedencia o el género, el alumnado que acudirá al centro presentará graves carencias, no sólo académicas, sino igualmente vitales. De esta forma, a la existencia de unos desfases educativos significativos, se le sumará a modo de corolario, la puesta en marcha de fenómenos de resistencia como el absentismo escolar, en sus más variadas formas (Romero-Villadóniga, 2018), la ausencia de habilidades sociales básicas, o el empleo de la violencia como 
herramienta comunicativa. A todo ello se le sumará una precariedad personal visibilizada en violencias multidimensionales, problemas de autocontrol, falta de empatía y asertividad, así como competencias emocionales limitadas.

Bajo este punto de partida, el conflicto que se generará respecto a la institución educativa, así como frente a sus actores, representantes de una sociedad hegemónica con un imaginario social totalmente divergente, respecto al que les dotan de sentido a sus vivencias y cotidianeidades, provocará la instauración de diferentes modalidades de violencias interpersonales, así como entre instituciones. Las consecuencias, a corto plazo, será el aumento de las discontinuidades entre la escuela y las familias, la potenciación del absentismo escolar como fenómeno de resistencia frente a la institución educativa, así como, en definitiva, una cronificación del fracaso escolar. Sin embargo, mucho peores serán las consecuencias generadas a medio y largo plazo, ya que se ayudará indirectamente a la cronificación de las situaciones de exclusión social de los sujetos, así como alejará a la institución de la auténtica finalidad para la que fue realmente concebida. Potenciará las violencias no sólo institucional, sino que, igualmente, reproducirá y legitimará otras de tipo simbólicas, ayudando a la instauración de microviolencias y brutalidades cotidianas en las relaciones interpersonales al no haber podido desarrollar unos hábitos sociales saludables (Romero-Villadóniga, 2019).

\section{Las gramáticas de la desconfianza y la incomunicación en la construcción de la violen- cia}

En la mayor parte de las casuísticas estudiadas, destacan una serie de denominadores comunes. La existencia de unos imaginarios sociales totalmente divergentes, la apreciación simbólica de un espacio donde las vivenciaciones y procesos de memorialización dan sentido de pertenencia a unos sujetos movidos por el miedo, la categoría social y/o grado de vulnerabilidad, harán acto de presencia de una forma u otra, a modo interseccional.

Sin embargo, en todos se dará un denominador común: la incomunicación como forma de alejamiento interpersonal. Como apunta Marta Rizo

Ser espectadores de la violencia, con la normalización y naturalización de la violencia que ello conlleva, hace que modifiquemos algunos hábitos cotidianos, condiciona nuestro actuar en el mundo de la vida cotidiana, nos genera miedo (consciente o no) y, en consecuencia, nos impide fortalecer los vínculos de confianza requeridos para una comunicación intersubjetiva e impersonal sana... La violencia se significa, sobre todo, a partir de juicios y percepciones subjetivas tales como el odio, el prejuicio, el dolor y el sufrimiento entre otros

(Rizo, 2012: 25) 
En todos los casos, la existencia de una gramática de la incomunicación servirá como catalizador del conflicto interpersonal, ya sea entre el alumnado y el profesorado, o entre éstos y el resto de la comunidad educativa. En todos, los diferentes subsistemas que operarán en el sujeto complejo interactuarán evitando situaciones neguentrópicas entre sus partes, fomentando, por el contrario, la generación de situaciones de desequilibrios los cuales necesitarán de agentes externos para una vuelta al orden.

Yo no tengo por qué decirle nada. Él llega (el profesor), con su maletín, lo abre y empieza a echarlos la bronca. No se para a preguntarse cómo estamos ni lo que hacemos fuera de clases. Tan sólo los deberes, explicar, y quien se entere se entere, y si no no es su problema. Con un "tio", así, yo paso de hablar y si tengo que liarla en clase la lío y a la mierda. Me voy al aula de guardia y ya está. Por eso vengo a verte, para que hables con él porque esto yo no lo aguanto, y si sigue así va a venir mi padre y la lía seguro.

(Diario de campo, 5 de noviembre de 2019)

Como se puede comprobar en el anterior ejemplo, la existencia de unas tramas profundas de incomunicación entre todos los agentes presentes en la escena, servirá como detonante de una situación de conflicto, siendo la intervención de un tercer actor el que logre generar nuevamente puentes de comunicación entre todas las partes. Ello no hace sino reafirmarnos sobre la idea de contemplar la violencia, en sus más variadas formas, como un lenguaje socialmente construido (Ferrándiz y Feixa, 2004) a partir de la intersección de multitud de variables, de ahí que debamos hablar de violencias interseccionables, con un elevado componente mutable y performativo.

Pero esta gramática de la incomunicación no se encuentra presente únicamente en el sistema educativo, muy al contrario. Permeará en todos los sistemas y subsistemas que operarán en el sujeto, haciendo que las auto-ego-referencialidades y auto-exo-referencialidades computen a través de la ausencia de esta. La liminalidad difusa de unos roles familiares definidos, la existencia de normas de convivencia interpersonales muy diferentes entre el sistema educativo y el familiar/barrio, así como el empleo de herramientas comunicativas diametralmente opuestas entre lo que se reclama desde la institución y las que dispone el entorno familiar, será igualmente fuente generadora de incomunicación entre todas las partes en conflicto.

No me grita ni mi padre y me vais a gritar vosotros, payos. Aquí lo que hay es mucho mal bajío con los de mi pueblo, mientras que a los payos los tratáis como reyes. En mi casa no me grita nadie, si me tienen que pegar me pegan y punto, pero no voy a aceptar que me griten porque eso no se lo consiento ni a mi padre, que es el que manda en lo mío.

(Diario de campo, 15 de noviembre de 2019) 
A la construcción de estas tramas de incomunicación, se le sumará la desconfianza como segundo elemento articulador en todas las etnografías realizadas. El partir de imaginarios sociales completamente diferenciados, así como el propio proceso de autoestigmatización al que se someterá el sujeto vulnerable (Quiles y Morera, 2008), generará un continuo recelo entre todas las partes en conflicto. Cuando Adela Cortina (2017) acuñó el concepto de "aporofobia", lo hizo precisamente pensando en este tipo de casuística. La categorización del sujeto por razón de su condición social, proyectará sobre éste toda suerte de estereotipos y prejuicios (Huici, 1996) los cuales, a su vez, ayudarán en la creación de determinadas estrategias de acercamiento interpersonal. Así, la condición de pobreza estructural, interseccionada con otras dimensiones como la procedencia social, el género o la etnia de pertenencia, proyectará sobre el sujeto vulnerable todo tipo de estereotipos negativos asociados, generando las denominadas "amenazas del estereotipo" (Steele, 1997; Shapiro y Neuberg, 2008), tales como su incapacidad de poder desarrollar su capacidad de reflexividad o su agencia. Será entonces cuando, por medio de formas de acercamiento asimétricas como la caridad, se desposeerá a los sujetos de sus capacidades, aumentando las asimetrías iniciales y violencias que se proyectarán sobre ellos.

Me encuentro en el Parque Moret junto con un alumno del máster de formación del profesorado que me han asignado, y P.M., profesora de $1^{\circ}$ de ESO . Como cada martes a última hora, intentamos hacer algo diferente con el alumnado, y esta vez se nos ha ocurrido dar un paseo tranquilo por el parque y así tomar contacto con la naturaleza. Cuando decidimos relajarnos sentados en uno de los bancos junto al área de juegos, se establece una conversación entre ambos realmente interesante.

-Alumno de prácticas (A.P.). Me da mucha pena lo que está pasando con toda esta gente. Viven en guetos y sin posibilidad de poder salir de él. Es más, por lo que me han contado algunos alumnos, muchos no quieren salir porque aquí al menos tienen a sus colegas y se sienten seguros.

-P.M. Sin duda, este es uno de los principales problemas del instituto, nos tienen como lo que somos, el recogedero de lo que nadie quiere o puede tener. Y en estas condiciones es difícil trabajar, ya que ellos mismos presentan problemas a la hora del trabajo.

-Yo. Esta situación se solucionaría si se pudiera abrir el centro a otras zonas y se permitiera una mayor permeación social, pero eso justamente no interesa a la Administración. Mientras funcionemos y no demos problemas nos seguirán teniendo en la misma situación.

(Diario de campo, 3 de abril de 2018)

Esta relación asimétrica, con un componente altamente desigual, despertará desconfianza entre todas las partes en conflicto, estableciéndose relaciones de desconfianza entre todos los 
actores, eliminándose cualquier atisbo de aproximación. Todo ello influirá en el auto-ego-centrismo de los sujetos, reforzando procesos de auto-estigmatización/exclusión por parte de unos, o de naturalización de la asimetrías por parte de otros.

Figura 2. Análisis de una situación de conflicto y subsistemas que operarán en él. Fuente: Romero-Villadóniga, 2019.

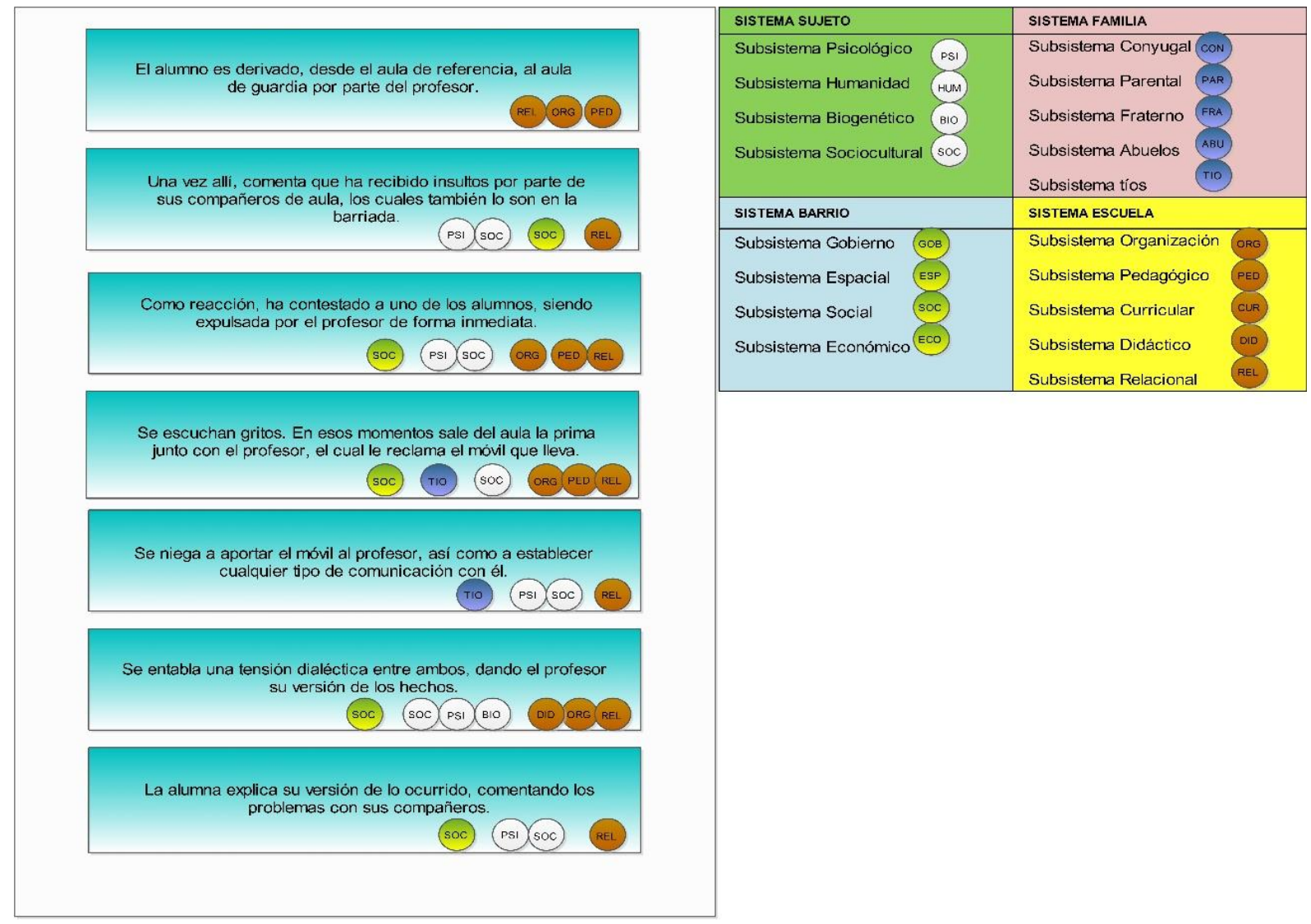

La ausencia de confianza tendrá como consecuencia más próxima la creación de diferentes formas de resistencia, no sólo interpersonales, sino también entre éstos y la institución, caso familiar y/o la educativa. Ello redundará en la dificultad de poder instaurar nuevas estrategias de acercamiento entre los sujetos, potenciando con ello, la incomunicación a modo de bucle recursivo. Todo ello no hará sino reafirmarnos en la idea de considerar el potencial performativo de la violencia, siendo éstas, dos de sus principales herramientas de génesis y/o consolidación.

\section{Hacia una nueva didáctica inclusiva}

Esta diversidad de intereses e imaginarios divergentes va a tener su repercusión directa en el aula. De esta forma, el currículo oficial no va a tener atractivo ni utilidad para las expectativas y cotidianeidades de los sujetos, generándose aprendizajes escasamente significativos para su 
devenir diario. Ello hará que el grado de interés y motivación por parte del alumnado/ familias no cumpla con las expectativas y requerimientos de la institución, provocando un desfase entre las necesidades y demandas de unos y otro

La consecuencia más inmediata de todo ello será la puesta en marcha de diferentes formas de violencias/resistencias por parte de todos los actores presentes en la acción. Así, por un lado, los desfases curriculares serán "pretendidamente" compensados mediante el desarrollo de una política de atención a la diversidad, la cual no hará sino cronificar las asimetrías y desigualdades del grupo frente al resto de la sociedad hegemónica, al no desarrollarse lo suficiente las diferentes competencias que componen el currículo. Ello provocará indirectamente, una guetificación del espacio educativo frente a otros centros de la zona, al asignársele sobre el alumnado una incapacidad innata a aprender. Esta cosificación se naturalizará a partir de la asimilación de tales deficiencias con la etnia de origen. Ser gitano/a será sinónimo en el imaginario de la ciudadanía, de una incapacidad inherente de poder aprender, asignándosele un rol de clara inferioridad frente al resto de la sociedad.

Pero paralelamente, esta cosificación e invisibilización de familias/alumnado, tendrá su reflejo en la puesta en marcha de gran cantidad de procesos de resistencia, los cuales se podrán visibilizar en aspectos tales como el absentismo escolar, el abandono prematuro de alumnado, especialmente femenino, o el conflicto dentro y fuera del aula. Por medio de ritualizaciones de estas prácticas, el alumnado buscará una salida no negociada del sistema, en un intento de evitar las tensiones generadas entre instituciones muy diferenciadas las cuales tendrán imaginarios divergentes entre sí.

Por esta razón, hace falta un cambio de rumbo. Abogar por un nuevo paradigma educativo el cual apueste por un empoderamiento de los sujetos, frente a las limitaciones y castraciones que impone la institución educativa. Y en este sentido, la cordialidad como conducta ética, permite una nueva manera de abordar la acción educativa a partir de la revalorización del sujeto como eje principal de toda la acción. Sin embargo, como apunta Pozzoli "los cambios verdaderamente estructurales y profundos, necesarios en el diseño curricular, poco avanzan, porque son miradas con recelo y son temidos. En realidad, en el trasfondo está la amenaza de que si ese cambio estructural se hiciera, traería consecuencias gravitacionales para el modelo de poder vigentes, para la distribución y control de los recursos, para la supervivencia de las asimetrías y la remoción y el recambio de muchos funcionarios y directivos" (Pozzoli, 2006: 3).

La adopción de la cordialidad como conducta ética, supone romper las limitaciones y encajes que se producen entre cada uno de los subsistemas, para volver a un nuevo estado neguentrópico, previo paso por otro entrópico, donde se resitúen las relaciones humanas como centro 
de todas las acciones a llevar a cabo. Y es en esta necesidad de reconceptualizar donde la cordialidad tiene su campo de acción. Formulada por autores como Ortega, Zurbiri o más recientemente Adela Cortina (2009), puede servir como puente entre el sujeto y la alteridad, ayudando en la generación de auto-exo-referencialidades y auto-ego-referencialidades las cuales computarán positivamente en el sujeto. Pero para que ésta pueda ser llevada a cabo, se debe partir de tres principios básicos:

- El vínculo interpersonal, o lo que es lo mismo, el reconocimiento de la alteridad como parte integrante de la humanidad, al tiempo que se configura como parte conformante del sujeto en su relación frente al resto. Ello supone aceptar una relación donde las ligazones y las obligaciones operan por medio de un principio dialógico de inclusión/exclusión (Solana, 2000) a través de las auto-ego-referencialidades, así como las exo-autoreferencialidades.

- La ley natural, en la que el ser humano se conforma a través de una lucha entre contrarios, encontrándose todo sometido a una continua dialógica, como bien esgrime el paradigma de la complejidad, disponiendo la reflexividad (Pozzoli, 2006), o la capacidad de agencia (Sen, 1999) un rol fundamental.

- La creatividad, pieza clave para una educación del futuro como apunta Chomski (2006), la cual ayudará en la construcción de una ética cordial por medio de herramientas básicas como la educación emocional.

Pero para que esta ética pueda ser llevada a cabo, se debe empoderar al sujeto a través de su capacidad de reflexividad y agencia. Abandonar una visión caritativa de la educación para pasar a otra donde la solidaridad (Romero-Villadóniga, 2017) cobre forma a partir de la asignación de responsabilidades a los sujetos, en igualdad de condiciones.

La aceptación de esta ética supone, en definitiva, resignificar la experiencia educativa a partir de la aceptación de la existencia de imaginarios diferentes y diferenciados, aunque no por ello de desigual valor. Todo ello se traduce en la necesidad de crear una nueva conciencia educativa (Morin, 1999), donde elementos como el azar, la incertidumbre, o la aleatoriedad, se consideren como elementos innatos de la interacción humana tanto dentro como fuera del aula.

Esta nueva forma de acercamiento a la alteridad va a tener consecuencias inmediatas en todos los subsistemas que componen la institución educativa, no quedando ajenas la propia concepción curricular y didáctica, las cuales tendrán que rediseñarse para poder romper con las 
lógicas cartesianas estandarizantes del sistema. Por ello, la adopción de nuevas estrategias didácticas parte como imprescindibles de cara a una integración de imaginarios y visiones tan diferenciadas, de ahí que suponga un cambio generalizado en el acercamiento del conocimiento.

Para el caso que nos ocupa, la progresiva introducción de una metodología y una didáctica basada en el Aprendizaje/Servicio (Furco, 2003; Tapia, 2006; Puig y Palos, 2006; Martín y otros, 2010; García-Rodicio y Silio-Sáiz, 2012), en el IES La Marisma, ha generado la aparición de nuevas gramáticas de comunicación y, por consiguiente, de confianza, entre todos los actores implicados, siendo un factor de ayuda en el desarrollo de hábitos positivos y un nuevo clima de convivencia. Ello supondrá, de inmediato, la creación de un proyecto solidario con una utilidad social práctica, permitiendo que todas las partes implicadas en la acción se nutran y puedan ser beneficiarias de su puesta en valor, así como favorecerá la creación de una pedagogía activa y reflexiva donde la experiencia, las memorialización, la participación y la reflexión serán los ejes articuladores de toda la experiencia.

Siguiendo a Lucas $(2009,2012)$, los requisitos básicos para la implementación de los proyectos de Aprendizaje-Servicio serán:

- El aprendizaje debe ir orientado a la prestación de un servicio hacia la comunidad beneficiaria, debiendo ser explícito en todo momento para todos los actores presentes en la acción.

- Deben ser aprendizajes orientados a la comprensión de la realidad y el desarrollo de la reflexividad por todas las partes implicadas, debiendo ser revisable en todo momento y susceptible de cambios al objeto de poder implementar medidas de mejora.

- La intervención debe ser real y para un entorno determinado por una necesidad real.

- El proyecto debe tener una finalidad básicamente propedéutica, debiendo ser evaluado constantemente por sus responsables.

- El papel de familias, alumnado, asociaciones y voluntariado debe ser activo. Deben intervenir en cada una de las partes del proyecto, desde la detección de necesidades hasta la puesta en marcha de posibles mejoras.

Todo ello se traducirá en una mayor autonomía de los sujetos, ayudándoles en el autocontrol $y$, por consiguiente, en una mejora de la autoestima. Del mismo modo, el trabajo cooperativo y participativo a partir de un principio de horizontalidad, ayudará en la coexistencia de ambos imaginarios, pasando de la divergencia a la convergencia en aspectos comunes, permitiendo, 
con ello, la generación de puentes de comunicación, entre todas las comunidades presentes en la escuela. Un cambio pedagógico y didáctico supondrá la creación de una verdadera escuela inclusiva, eliminando su guetificación frente al resto, al disponer de un carácter y señas de identidad propias en las formas de transmisión del conocimiento. La generación de nuevos roles, la asignación de responsabilidades en los sujetos de forma equitativa, la introducción de las familias en la acción, o la resignificación de espacios y normas, ayudará en la creación de nuevas referencialidades las cuales facilitarán una redimensión del auto-ego-centrismo del sujeto complejo.

Este cambio metodológico y pedagógico no ha estado exento de problemas. La rigidez de los diferentes subsistemas, así como las reticencias mostradas por los diferentes actores, recordemos la importancia que van a tener en este contexto las gramáticas de la desconfianza y la incomunicación, serán serios escollos para superar, al provocar dentro del propio sistema educativo, procesos de continuas entropías, generando equilibrios/desequilibrios/reequilibrio, a medida que se vayan implementando las diferentes propuestas de intervención. Y será en este nivel cuando la cordialidad como conducta ética, permitirá un acercamiento a los diferentes actores, a través de las relaciones que establecerán desde el subsistema relacional, permitiendo una interacción compleja de los diferentes subsistemas.

La adopción del Aprendizaje/Servicio ha supuesto, entre otras cosas, la necesidad de introducir cambios no sólo en lo referido a la organización del centro, y los currículos en sí, sino igualmente, ha supuesto una modificación en el planteamiento didáctico, resignificando los roles a jugar por cada uno de los actores, así como las propias finalidades de la educación en sí misma.

Fruto de ello, actualmente se han introducido, o se encuentran en proceso, varias líneas de intervención basadas en esta metodología:

- Programa "Educando desde los Sabores". Puesto en marcha desde hacia varios cursos académicos, supondrá la primera aproximación a este tipo de metodología. Inicialmente diseñado desde el área de Geografía e Historia, articulará y vertebrará todo el currículo de la asignatura para todos los cursos, a partir de la necesidad de adquirir buenos hábitos saludables en materia de preparación y consumo de alimentos. En un colectivo acostumbrado a la ingesta de bollería industrial, así como a comidas precocinadas y/o las denominadas comidas basura, la introducción de este taller supondrá trabajar la importancia que tendrá una buena alimentación en la prevención de problemas tales como el colesterol, o el azúcar, presenten entre los estudiantes. Para ello se contará con la cons- 
tante colaboración de familias y asociaciones presentes en la zona (Romero-Villadóniga, 2016), teniendo un papel protagonista en la acción. De esta forma, el reparto de tares, la resignificación de roles de todos los actores presentes, o la participación activa de todos, supondrá la creación de un espacio de comunicación entre las partes, así como dotará de significatividad la práctica docente.

- Observatorio de Convivencia. De reciente creación, responde a una serie de objetivos claramente delimitados: promover un clima de Paz en todo el centro educativo y entre todos los agentes participantes en el mismo.; detectar situaciones de conflicto las cuales provocan situaciones de violencia en sus múltiples variantes, así como delimitar los diferentes tipos de conflictos presentes en el centro educativo, visibilizando ante la comunidad educativa, las diferentes estrategias de resolución que se pueden articular. A partir de un principio de horizontalidad en los roles asignados, metodología cooperativa, espíritu crítico positivo y creatividad, todos los actores presentes en el mismo (profesorado, alumnado, familias, personal de administración y servicio, asociaciones y servicios sociales), establecerán líneas de trabajo muy específicas las cuales girarán alrededor de la lucha contra la violencia dentro y fuera del centro educativo, analizando las diferentes casuísticas que se presentan, así como proponiendo mejoras a introducir, especialmente dentro del entorno educativo, las cuales serán trasladadas a los equipos directivos para su estudio y/o puesta en marcha. Gracias a este modelo de intervención, la norma pasará a convertirse de impuesta a consensuada, permitiendo un acercamiento entre las partes, aspecto éste muy importante cuando entran en juego imaginarios y construcciones culturales divergentes, como en el caso que nos ocupa.

- Proyecto "Aprendo a Cuidarme". En proceso de construcción actualmente, se prevé su puesta en marcha en el segundo trimestre del curso académico 2019/2020. Las necesidades detectadas entre el alumnado/familias nos han orientado a la creación de este proyecto integrado por familias/alumnado, profesorado y profesionales del sector, tales como enfermeros y médicos voluntarios y alumnado de la carrera de psicología. Las frecuente presencia de hábitos nocivos por parte del alumnado/familias, tales como la ingesta de alimentos pocos saludables, el consumo de tóxicos como el tabaco, alcohol y drogas a edades muy tempranas (12-13 años), o la presencia de patologías psicológicas e cierta importancia (ansiedad o depresión), por un segmento significativo de alumnado, impulsa la necesidad de crear este proyecto, el cual tratará de empoderar al alumnado especialmente, para que, por medio de su capacidad de reflexividad y agencia, pueda 
desarrollar hábitos de vida saludables, los cuales les permitan poder mejorar sus condiciones de salud.

Todos estos programas se encuentran, no obstante, con problemas a la hora de su implementación. A las reticencias del profesorado, familias y alumnado iniciales, se le vendrán a sumar las propias rigideces de un sistema educativo encorsetado en unos ritmos y estilos de aprendizaje, los cuales limitarán y castrarán las intervenciones en determinados momentos. Ello no hace sino hacernos ver cómo la propia institución es, de por sí generadora de tensiones y violencias hacia los sujetos, debido a la propia inercia de funcionamiento que tendrá como tal. Por esta razón, la implementación de proyectos y programas basados en Aprendizaje/Servicio deben tener estas limitaciones presentes a la hora de su diseño y puesta en marcha, ya que, de lo contrario, las tensiones que se generarán podrían poner en riesgo el éxito de las intervenciones y, por consiguiente, del proyecto en sí.

\section{Conclusiones}

La intervención educativa en contextos donde la vulnerabilidad social se intersecciona con dimensiones como el género o la etnia, no resulta tarea nada fácil. La existencia de imaginarios sociales totalmente divergentes entre actores, así como entre las propias instituciones en juego, dificultad sobremanera la instauración de unas habilidades sociales positivas para todas las partes. La institución educativa, como instrumento cuya finalidad primordial es la reproducción del sistema social, por medio de la enculturación de todos sus miembros, va a provocar en el sujeto vulnerable fenómenos de aculturación en el seno de su comunidad de origen, las cuales serán respondidas con resistencias en sus más variadas formas.

Así, por medio de una cuidada puesta en escena se organizarán currículos, se propondrá una línea de intervención pedagógica, así como se incorporarán herramientas y didácticas las cuales se adaptarán a la "diversidad del alumnado". Sin embargo, tras esta aparente organización se esconderán prácticas invisibilizadas por el propio sistema, de reproducción de las asimetrías sociales, generando lo que Bellamy denomina una "educación de desheredados de la sociedad" (2015; 2016). El resultado final será un modelo didáctico y pedagógico alejado de la realidad social del alumnado y las familias, los cuales son perfectamente encajables en la mayoría que compone la sociedad hegemónica, pero no para estos casos.

No contar con la construcción cultural en la cual desarrollan los sujetos sus cotidianeidades, supone abogar ineludiblemente por el más absoluto de los fracasos. La guetización de la educación por desgracia, es un hecho, por más que deseemos repudiarla y condenarla. Condenar al 
alumnado a la repetición mecánica de contenidos y a un aprendizaje estandarizado, por mucho que se ajuste a los perfiles curriculares de los mismos, es seguir reproduciendo la clasificación social reinante, siendo una fuente de violencia naturalizada tan peligrosa o más que cualquier otra.

Por esta razón hace falta repensar la Educación como Acción. Hacer que los actores que intervienen en ella, puedan desarrollar aprendizajes a partir del cuerpo social y el entramado cultural que les da sentido de pertenencia. Abandonar la caridad para apostar por la cordialidad como forma de acercamiento entre la institución y el entorno humano, supone dar un paso cualitativo, al dotar de empoderamiento y visibilidad a los protagonistas, el alumnado y las familias.

Hace falta un cambio en la concepción pedagógica, pero igualmente hace falta incorporar una nueva visión de la acción educativa, de los roles que deben jugar profesorado, familias, alumnado, asociaciones, personal de administración y servicios y todos aquellos colectivos que, de una forma u otra, intervienen en el proceso. Por esta razón, estrategias como el Aprendizaje/Servicio supone dar un paso más allá, abandonar la rigidez de un sistema que se muestra incapaz de atender realmente en la diversidad.

Abrir la realidad educativa a todos los actores presentes, dotándoles de nuevos roles y empoderándoles en la acción, permite tomar el entorno como un recurso didáctico de primer orden, permitiendo igualmente, una intervención directa sobre los sistemas familia y barrio, imposibles de poder acceder desde un pensamiento académico clásico. Por esta razón, si lo que se pretende es generar una verdadera Educación para el Siglo XXI, como apunta Morín (1999), debemos empezar por volver a dar protagonismo al sujeto-individuo, potenciando sus capacidades reflexivas y de agencia, por medio de la dotación de responsabilidades a todas las partes en litigio. Sólo así el sistema educativo, como institución, podrá tener un valor añadido real, en contextos de vulnerabilidad social donde la componente étnica marca sus derroteros. 


\section{Bibliografia}

Ávila, D \& García, S. (2015). Enclaves de riesgo. Gobierno neoliberal, desigualdad y control social. Madrid: Traficantes de Sueños.

Bellamy, F.X. (2015). Pourquoi enseignons-nous?. Clermont-Ferrand: SOS Education.

Bellamy, F.X. (2016). Les déshérités ou l'urgence de transmettre. Paris: Plon.

Biasatti, S. \& Compañy, G. (2015). Memorias sujetadas. Hacia una lectura crítica y situada de los procesos de memorialización. Madrid: Service Point.

Bourdieu, P. (1999). La miseria del mundo. México: FCE.

Bourgois, P. (2009). "Treinta años de retrospectiva etnográfica sobre la violencia en las Américas”. en LÓPEZ, J. (Coord). Guatemala, violencias desbordadas. Córdoba: Servicio Publicaciones Universidad de Córdoba, 29-62.

Capra, F. (2003). Las conexiones ocultas. Barcelona: Anagrama.

Consejo Escolar de Andalucía (2006). Informe sobre la convivencia en los centros educativos. Granada: Consejo Escolar de Andalucía y Consejería de Educación de la Junta de Andalucía. (datos obtenidos el 12/10/2019).

Cortina, A. (2009). Etica de la Razón Cordial. Oviedo: Nobel.

Cortina, A. (2017). Aporofobia: el rechazo al pobre. Barcelona: Paidós.

Chomsky, N. (2016). La des-educación. Barcelona: Austral.

Defensor del Pueblo (2000). Informe sobre violencia escolar: el maltrato entre iguales en educación secundaria obligatoria. Madrid: Publicaciones de la Oficina del Defensor del Pueblo.

Defensor del Pueblo (2007). Violencia escolar: el maltrato entre iguales en la educación secundaria obligatoria 1999-2006 (nuevo estudio y actualización del informe 2000). Madrid: Defensor del Pueblo.

Distrito V (2016). Plan estratégico 2016/2020.

Http://www.distrito5huelva.org/portal/index.php/archivo/documentos/category/publicaciones/ 2 (datos obtenidos el 2/10/2019)

Ferrándiz, F. \& Feixa, C. (2004). "Una mirada antropológica sobre las violencias". Alteridades, 14 (27). 159-174.

Furco, A. (2003). "Issues of definition and program diversity in the study of service learning" en S. H. Billig (Ed.). Studying service-learning. London: Lawrence Erlbaum Publishing Company, 11-30.

García-Rodicio, H. \& Silió-Sáiz, G. (2012). “Tomando la temperatura al AprendizajeServicio. ¿Qué procesos de aprendizaje, fríos y cálidos, promueve?”. Revista Iberoamericana de Educación, 60 (2), 1-11.

Huici, C. \& Morales, J. (1996). Psicología Social y Trabajo Social. Madrid: Mc Graw-Hill. 
Instituto canario de evaluación y calidad educativa (ICEC) (2005). La convivencia en los Centros Educativos de Secundaria de la Comunidad Autónoma Canaria. Evaluación e investigación educativa. Xesús Rodríguez Jares. Canarias: Consejería de Educación, Cultura y Deportes del Gobierno de Canarias.

Lucas, S. (2009). "Psicología Social de la Educación y Desarrollo de Competencias clave para el aprendizaje permanente: Programas comunitarios de educación, formación y orientación profesional”. en AAV (eds) Actas del XI Congreso Nacional de Psicología Social. Tarragona, 1-3 de octubre de 2009. Tarragona, Eds: Jordi Tous Pallarés \& Joan Manuel Fabra Sopeña.

Lucas, S. (2012). “Aprendizaje-Servicio como propuesta de integración curricular del Voluntariado en la Responsabilidad Social Universitaria”. en AAVV (eds.) Actas de Jornadas sobre Responsabilidad Social. Valladolid: Universidad de Valladolid y Caja de Burgos.

Martín, X.; Rubio, L.; Battle, C. \& Puig, J. M. (2010). Prácticas de ciudadanía. Diez experiencias de aprendizaje servicio. Barcelona: Octaedro.

Morin, E. (1999). Los siete saberes necesarios para la educación del futuro. Madrid, Santillana.

Morin, E. (2004). Introducción al pensamiento complejo. México: D. F, Gedisa.

Observatorio estatal de convivencia escolar (2010). Estudio estatal sobre la convivencia escolar en la Educación Secundaria Obligatoria. Madrid: Ministerio de Educación, Catálogo de Publicaciones del Ministerio.

Oñate, A. \& Piñuel, I. (2007). Informe Cisneros X: acoso y violencia escolar en España. Alcalá de Henares. Madrid: Instituto de Innovación Educativa y Desarrollo Directivo.

Pozzoli, M.T. (2006). "El trato amable del sujeto complejo". Revista Hermenéutica Intercultural, n 15, 139-166.

Prieto, J.L. (1996). Mensajes y señales. Barcelona: Six Barral.

Puig, J. M. \& Palos, J. (2006). "Rasgos pedagógicos del aprendizaje-servicio”. Cuadernos de Pedagogía. 357, 60-63.

Quiles, M. N., \& Morera, M. D. (2008). "El estigma social: la diferencia que nos hace inferiores”, en Morales, J., Huici,.C., Gaviria, E. y Gómez, A. (Coords.). Método, teoría e investigación en psicología social. Madrid, Pearson: 377-397.

Rizo, M. (2012). "Comunicación, intersubjetividad y violencia. Algunas reflexiones en torno a la debilitación de las relaciones comunicativas en entornos violentos”. en Rizo, M \& Romeu, V (eds). Comunicación, cultura y violencia. Bellaterra: ICAB, 23-32.

Romero-Villadóniga, J.C. (2016). "Educado desde los sabores. Una experiencia antropoeducativa en una población de riesgo”. Investigación en la Escuela. 90, 34-48.

Romero-Villadóniga, J. C. (2017). "Miedo educativo. Las tramas de la violencia en espacios de vulnerabilidad social". en AAVV (Ed.). Desigualdades educativas, políticas públicas y etnografía crítica en España. Valencia: Universidad de Valencia, 988-1001. 
Romero-Villadóniga, J.C. (2018). "El absentismo escolar en contextos de vulnerabilidad social. Una reflexión antropológica". Forum Sociológico. 32, 49-57.

Romero-Villadóniga, J.C. (2019). Una antropología compleja. Las tramas de violencia en un contexto educativo con vulnerabilidad social. La Cordialidad como alternativa. Tesis doctoral inédita defendida el 13 de junio de 2019 en la Facultad de Humanidades de Toledo, UCLM. En la Red: https://ruidera.uclm.es/xmlui/handle/10578/41 (datos obtenidos 20/10/2019).

Romeu, V (2012). "Comunicación interpersonal e incomunicación: Una aproximación a las gramáticas de la desconfianza". en Rizo, M \& Romeu, V (eds). Comunicación, cultura y violencia. Bellaterra. ICAB, 1-22.

Sen, A. (1999). Nuevo examen de la desigualdade. Madrid, Alianza.

Shapiro, J. R. \& Neuberg S. L. (2007). "From Stereotype Threat to Stereotype Threats: Implications of a Multi-Threat Framework for causes Moderators". Personality and Social Psychology Review. 11 (2). 107-130.

Solana, J. (2000). Antropología y complejidad humana. La antropología compleja de Edgar Morin. Jaén: Comares Editorial.

Steele, C. M. (1997). “A threat in the air: How Stereotypes Shape the intellectual identities and performance of women and African Americans". American Psychologist. 52 (6). 613 629.

Tapia, M. N. (2006). Aprendizaje y servicio solidário. Buenos Aires: Ciudad Nueva. 


\title{
Capítulo 6. \\ Literacia digital das pessoas ciganas de Reguengos de Monsaraz
}

\author{
CARLOS MEDinas ${ }^{1}$ \\ Doutorando em Relações Interculturais, Universidade Aberta \\ Câmara Municipal de Reguengos de Monsaraz \\ cb.medinas@gmail.com
}

\section{Olga MAGANO}

Professora Universidade Aberta e Investigadora do Centro de Investigação e Estudos em Sociologia (CIES-Iscte), Instituto Universitário de Lisboa

olgamagano@gmail.com

Resumo: Através de um estudo desenvolvido em Reguengos de Monsaraz procurou-se conhecer de que forma é que as pessoas ciganas acedem e manuseiam recursos tecnológicos e de informação, essenciais para a vida quotidiana nas sociedades contemporâneas.

Com esse objetivo foi aplicado um inquérito por questionário a pessoas ciganas residentes em Reguengos de Monsaraz cujos resultados revelam que 75\% dos inquiridos abandonaram a escola e $38 \%$ não sabem ler, ou seja, é revelado um quadro de analfabetismo, abandono escolar e iliteracia, que são os principais constrangimentos para exercer a literacia digital. Apesar de as pessoas ciganas já terem contactado com alguma forma de tecnologia há dificuldades em aceder a computadores e a Internet: por um lado, são poucas as pessoas que dispõem destes serviços e equipamentos em casa e, por outro lado, não têm competências suficientes para um uso autónomo. Muitos ciganos reguenguenses acedem a equipamentos e à Internet nos espaços municipais, no entanto, responsáveis destes espaços salientam as dificuldades de leitura e escrita, sendo necessário um apoio personalizado. Ou seja, verifica-se que a situação de pobreza e exclusão em que esta população se encontra provoca um outro tipo de exclusão, que é a infoexclusão e a iliteracia traduzida também em iliteracia digital.

Palavras chave: Ciganos; Literacia Digital; Internet; Exclusão; Inclusão; Fratura digital

\footnotetext{
${ }^{1}$ Mestre em Relações Interculturais pela Universidade Aberta e doutorando em Relações Interculturais. Elaborou a dissertação de mestrado "Ciganos e literacia digital: o caso de Reguengos de Monsaraz". É técnico superior na Câmara Municipal de Reguengos de Monsaraz.
} 
Abstract: Through a study developed in Reguengos de Monsaraz, it was sought know how Ciganos access technological and information resources and how to handle them, which are essential for daily life in contemporary societies.

A questionnaire survey was applied to Ciganos in this municipality whose results reveal that $75 \%$ of respondents left school and $38 \%$ do not know how to read, that is, they reveal a situation of illiteracy, school dropout and illiteracy, which are the main constraints for digital literacy. Although Ciganos have already had contact with some form of technology, there are difficulties in accessing computers and the Internet: on the one hand, a few people have these services and equipment at home and, on the other hand, they do not have enough skills to autonomous use. Many Ciganos have access to equipment and the Internet in the municipal spaces, however, those responsible for these spaces point the difficulties of reading and writing, requiring personalized support. In other words, it appears that the situation of poverty and exclusion in which this population finds itself causes another type of exclusion, which is info-exclusion and illiteracy translates also into digital illiteracy.

Keywords: Ciganos/Roma; Digital Literacy; Internet; Exclusion; Inclusion; Digital fracture

\section{Introdução}

A bibliografia em Portugal revela que as pessoas Ciganas são, de um modo geral, pouco escolarizadas, havendo ainda altas taxas de analfabetismo e dificuldades de cumprir a escolaridade obrigatória. Numa sociedade em que predomina a tecnologia e a informação digital interessanos verificar como é que as pessoas ciganas se posicionam e interagem com estas tecnologias na sua vida quotidiana. Assim, este artigo tem por objetivo refletir em torno do conhecimento sobre a literacia digital e não digital das pessoas ciganas de Reguengos de Monsaraz e a forma como se relacionam com a sociedade tecnológica e digital ${ }^{2}$. Para a realização desta investigação recorreu-se a uma combinação de metodologia quantitativa (inquérito por questionário aplicado a pessoas ciganas residentes no concelho) e qualitativa (entrevistas a alguns interlocutores privilegiados) em que se delimitaram algumas dimensões de modo a traçar os perfis sociodemográficos, o tipo de acesso a equipamentos tecnológicos, informáticos e internet e também quanto ao conhecimento de manuseamento desses instrumentos.

\footnotetext{
${ }^{2}$ Este artigo tem por base a dissertação de mestrado em Relações Interculturais de Carlos Boto Medinas, "Ciganos e Literacia Digital: estudo de caso em Reguengos de Monsaraz", Universidade Aberta.
} 


\section{O mundo em mudança e a sociedade informacional fraturante}

A informática, a par com os desenvolvimentos tecnológicos nas telecomunicações, o nascimento da internet e a World Web Wide, são denominadas por novas tecnologias, que provocam uma mudança radical originando, de acordo com Castells, (1999) a sociedade informacional. O autor salienta que no modo de desenvolvimento industrial a fonte de produtividade residia nas fontes de energia, mas para o atual modo informacional é a geração de conhecimento e processamento de informação o principal motor de desenvolvimento. As duas últimas décadas do século XX pautam-se pela crescente utilização da World Wide Web no trabalho e no lazer, ocupando cada vez mais espaço das esferas de vida dos cidadãos.

Com as sociedades informacionais (Castells, 1999), do conhecimento ou da sociedade em rede, a fonte principal de produtividade é a tecnologia de geração de conhecimentos, de processamento da informação e de comunicação de símbolos. Nesta sociedade os conhecimentos das pessoas literadas, com escolaridade, não são suficientes. É uma nova sociedade onde, para além de se saber ler e escrever, é necessário saber utilizar novas tecnologias digitais, ou seja, é necessário saber utilizar computadores.

Esta nova sociedade baseada no processamento da informação depara-se com a necessidade de aceder a computadores e de saber utilizá-los, o que causa uma enorme fratura nas sociedades humanas, atendendo a que uma parte significativa da população mundial ainda se encontra afastada desta realidade. De acordo com Sanou (2016), é sobretudo em áreas do hemisfério norte que o acesso à internet é praticamente generalizado, enquanto os territórios do hemisfério sul, exceto a Austrália, são territórios com baixos índices de utilização da internet. Constata-se que nos países desenvolvidos a internet tem uma penetração de utilização de $81 \%$, descendo para os $40 \%$ nos países em desenvolvimento e $15 \%$ nos países mais pobres, sendo que é possível concluir que, a nível mundial, mais de metade da população não utiliza a internet, de acordo com o relatório da União Internacional de Telecomunicações (Sanou, 2016). Assim, é possível verificar diferentes velocidades a que o mundo vai evoluindo revelando diferenças abissais entre os mais ricos e poderosos e os menos favorecidos e que se traduzem no acesso e uso de acesso a informação e tecnologias digitais. Esta diferença no acesso às tecnologias de informação é notória entre os hemisférios norte e sul, entre países, também no interior dos países nas diversas regiões e ainda entre os diversos grupos sociais constituintes das sociedades. Em Portugal, de acordo com a ANACOM (Autoridade Nacional de Comunicações), os grupos sociais que menos acedem à internet são: os mais idosos, os menos escolarizados, desempregados e reformados, os mais pobres e desprotegidos (ANACOM, 2016). Para Castells (1999), os que não acedem ou têm dificuldades no acesso à internet são arredados do acesso à informação, e 
constituem os infoexcluídos. A infoexclusão é uma "fratura aberta entre pessoas, empresas, instituições, regiões e sociedades, que detêm todas as condições materiais e culturais para se movimentarem corretamente no mundo digital e os que não possuem essas condições ou não querem adaptar-se, à mudança para a nova organização social baseada nas tecnologias de informação" (Castells, 2007, p. 312). Os grupos sociais referidos por Castells (1999) utilizam menos ou não utilizam de todo a internet, o que configura situações de infoexclusão pela desigualdade no acesso, sendo que,

A disparidade entre os que têm e os que não têm Internet amplia ainda mais o hiato da desigualdade e da exclusão social, numa complexa interação que parece aumentar a distância entre a promessa da Era da Informação e a crua realidade na qual está imersa uma grande parte da população mundial.

(Castells, 2007, p. 187).

Se no início da expansão das tecnologias de informação o enfoque da fratura digital se poderia colocar no acesso a computadores e internet, mais tarde a fratura ou fosso digital deslocouse para a questão da utilização adequada, criativa e reflexiva das tecnologias de informação como instrumentos privilegiados da interação entre o estado e os cidadãos através do $e$-government.

Esta utilização intensa e massiva dos meios digitais quer para trabalho, estudo e recreação, continua a produzir novos infoexcluídos tal como Castells refere, quando analisa dados dos EUA, constatando que a desigualdade no acesso à internet também se verifica na diferenciação étnica, isto é, a cor da pele ou cultura condicionam o acesso à internet, o que constitui uma infoexclusão étnica. A infoexclusão tem uma ligação muito nítida com a exclusão social, podendo cada uma ser causa e consequência da outra. E a exclusão social pode ser perspetivada entendida como “(...) situação de não inclusão, de não-inserção e/ou de não integração de determinados indivíduos ou grupos socias no acesso ao gozo de determinados direitos, desde os cívico-políticos, passando pelos sociais, até aos direitos económicos.” ( Silva, 2008: 270).

A exclusão social pode surgir devido também a fatores culturais. Nesta tipologia de exclusão social enquadram-se as diversas formas de racismo, assim como a xenofobia e algumas formas de nacionalismo, em que se inscrevem as minorias étnico-culturais, como por exemplo os ciganos, conforme nos indicam Bastos et al. (2007) "os ciganos portugueses se encontram numa situação multissecular de discriminação etnoracial perpetuada" (p.52).

No atual paradigma informacional (Castells, 1999), é necessário possuir competências que vão muito para além do domínio da leitura, da escrita e cálculo numérico. É, pois, necessário 
possuir competências para lidar com sistemas digitais, como computadores, smartphones, tablets, e todos os diversos dispositivos digitais que permitam uma interação com os seres humanos. O conceito de literacia digital surge para dar conta destas novas necessidades com que se debatem os cidadãos de sociedades informacionais. De acordo com Glister (1997), "literacia digital" consiste na "habilidade de entender e utilizar a informação de múltiplos formatos e proveniente de diversas fontes quando apresentada por meio de computadores." (p. 1). Para o autor existem quatro competências fundamentais para o exercício de literacia digital: pesquisas na Internet; navegação no hipertexto; construção (montagem) do conhecimento e avaliação de conteúdo. A rápida e constante inovação do sector da eletrónica e telecomunicações tem vindo a forçar o conceito de literacia digital a ser cada vez mais amplo e abrangente por forma a abarcar também as necessárias e exigentes competências de utilização das tecnologias, uma vez que são cada vez mais as áreas e serviços a serem digitalizados.

No sentido de fundamentarmos a nossa investigação e tendo em consideração a população alvo do nosso estudo tomámos como referência teórica o mapa conceptual de Ala-Mutka (2011), para evidenciar a abrangência do conceito de literacia digital em relação a outras literacias, e também basear a construção do questionário nos domínios da literacia dos computadores; literacia da internet; literacia dos média e da informação. Neste mapa conceptual o centro é representado pelo conhecimento técnico como a utilização de computadores e aplicações de software. A literacia da internet representa as capacidades de utilizar e agir em ambientes em rede na web. Nesta configuração, a literacia digital é entendida como um conceito amplo que abrange os principais aspetos de todas literacias, sendo que é condição previa possuir competências para lidar com a tecnologia e a internet, que constituem as competências básicas.

\section{A situação das pessoas Ciganas em um mundo preconceituoso}

Estima-se que os ciganos tenham chegado a Portugal nos finais do século XV tendo esta data suporte nas referências a ciganos em diversas obras literárias. A referência a ciganos é explícita desde o século XVI, prova disso é o facto de em 1510 uma poesia de Luís da Silveira, ter sido incluída na obra O Cancioneiro Geral, de Garcia de Resende, e em 1521 é editada a Farsa das Ciganas de Gil Vicente. Adolfo Coelho (1892) e Nunes (1996) fazem referência a estes documentos, como prova da presença dos ciganos em Portugal.

A permanência em território português dos ciganos faz deles o grupo étnico com o qual os portugueses mais tempo têm convivido e simultaneamente o grupo com que mantêm uma relação maior de hostilidade e conflitualidade do que resultou o isolamento e exclusão social. Para ilustrar esta situação é suficiente procurar nos limítrofes de algumas cidades os "acampamentos 
de ciganos" e olhar as condições em que vivem: barracas, sem água, sem eletricidade, analfabetismo e desemprego (por exemplo, Évora, Beja, etc.).

Os mais de 500 anos de permanência em Portugal das pessoas ciganas revelam um penoso caminho de discriminação como ilustra Bastos et al., (2007) ao apresentar uma compilação de leis, regulamentos e decisões administrativas sobre os ciganos, desde 1526, que exercem forte coercividade física e cultural contra os ciganos. Os autores acrescentam ainda que "Que os portugueses «ciganos» que hoje conhecemos são o resultado direto da história violenta e até mesmo criminosa a que os submetemos..." (p.34)

Atualmente, parece existir um esforço para que as difíceis condições de vida das pessoas ciganas sejam tornadas visíveis para a sociedade maioritária. A nível nacional algumas políticas sociais, que não são exclusivas para as pessoas ciganas, trazem ao de cima o quanto falta fazer para minorar os maiores problemas com que os ciganos se debatem: habitação; educação e emprego, para além da forte rejeição da população maioritária.

De facto, a maioria dos portugueses tem uma representação social negativa da pessoa cigana, expressões como "Um olho no burro outro no cigano"; "casa de ciganos" ou "cheira a cigano" (Medinas, 2018: p. 61). Também para Liégeois, (1989) "Na maior parte dos países, o termo utilizado para designar em comum ciganos e itinerantes é pejorativo e, por si só, portador de toda a negatividade da imagem (...)" (p. 138).

Tradicionalmente, a cultura cigana é considerada como uma cultura agrafa, transmitida oralmente e por uma língua cada vez menos utilizada (Nunes, 1996). É nas atitudes aprendidas durante a socialização na infância, que é construída aos poucos a identidade pessoal dos indivíduos e do grupo a que pertencem. A cultura cigana tem sido sujeita a um processo de aculturação, ou seja, uma mudança cultural motivada pelo contato com outras culturas, originando uma reação de mudança face à cultura maioritária. A este processo a que as pessoas são sujeitas, numa reação à mudança cultural no contacto com outras culturas, é definido como aculturação.

Berry desenvolveu um modelo de aculturação (referido por Neto, 2004) tendo como base duas dimensões de aculturação (bidimensional). Numa das dimensões é dado maior enfase à importância da conservação da identidade e as características culturais, na outra dimensão é dada maior enfase à importância de procurar estabelecer e manter relações com os outros grupos da sociedade. $\mathrm{O}$ autor, tendo com suporte este modelo bidimensional, desenvolveu 4 possíveis estratégias ou atitudes de aculturação: 1) Assimilação, quando indivíduos e grupos, aceitam e absorvem os valores culturais da cultura de acolhimento; 2) A separação: indivíduos e grupos aderem aos valores da sua cultura de origem, em detrimento à aceitação da cultura de acolhimento. 3) A integração: indivíduos ou grupos aceitam e aderem aos valores e normas culturais 
de ambas as culturas; 4) Marginalização: em que o indivíduo ou grupo não aceita nem adere aos valores de nenhuma das culturas, nem de origem nem de acolhimento.

Em face deste conceito, a estratégia seguida pelos ciganos em Portugal parece-nos ter sido a separação, no entanto, as culturas não são estáticas e vão recebendo influências. Recentemente temos muitas pessoas ciganas que estão integradas, o que nesta estratégia de aculturação significa que aceitam e aderem aos valores e normas culturais da sua cultura de origem e que aceitam também a cultura e valores da sociedade maioritária. Magano (2010), refere que as pessoas ciganas não são todas iguais e não podem ser consideradas de forma homogénea. Há pessoas ciganas escolarizadas e com exercício de profissões diferentes das tradicionalmente imputadas aos ciganos.

A integração das pessoas ciganas é um processo que decorre em Portugal há pelo menos 500 anos, perante uma "sociedade que os quer assimilar e que apresenta caraterísticas inversas: individualismo, capitalização, previsão, sedentariedade, uniformidade, competitividade, dependência, etc.". (Liégeois, 1989, p. 86). Adolfo Coelho refere que "Há quatro preceitos na lei cigana, que todos procuram cumprir integralmente: respeito à palavra dada entre os da sua raça, amor extremoso aos filhos, fidelidade conjugal, respeito pelos velhos. E poderíamos acrescentar: a fraternidade e solidariedade, e a guarda da virgindade, nas raparigas solteiras" (referido por Nunes, 1996:140). De acordo com o autor, os ciganos, ao longo dos séculos adaptaram a sua forma de vida de acordo com as oportunidades que o ritmo da evolução social e económica da sociedade maioritária lhes permitia. As suas atividades tradicionais têm vindo a ser extintas, como por exemplo as atividades de artesanato e atividades de venda e trocas de animais em feiras. A venda de tecidos a metro evoluiu para roupas prontas nos diversos mercados em vilas e cidades cada vez menos frequentados o que cada vez mais empurra estas pessoas para as fronteiras limiares da inatividade e dependência dos subsídios estatais. Toda esta rápida transformação traz ao de cima a falta de competências de literacia e aptidões profissionais cuja consequência, a par com o racismo da sociedade maioritária, é a ausência de trabalho (leia-se emprego) para as pessoas ciganas e a que o Estado não tem sido capaz de responder (Pereira, 2016). Sobram, para os que os conseguem, alguns trabalhos sazonais em Portugal e Espanha na apanha da azeitona, vindimas, morangos, peras ou cerejas, até que a mecanização cada vez mais utilizada o permita.

Apesar da persistência de baixa escolaridade entre as pessoas ciganas, verifica-se que em relação aos últimos 20 anos, duplicou o número de estudantes ciganos na escola obrigatória, como podemos ver pelo Gráfico 1. 
Gráfico 1. Evolução de Ciganos matriculados em escolas de Reguengos de Monsaraz

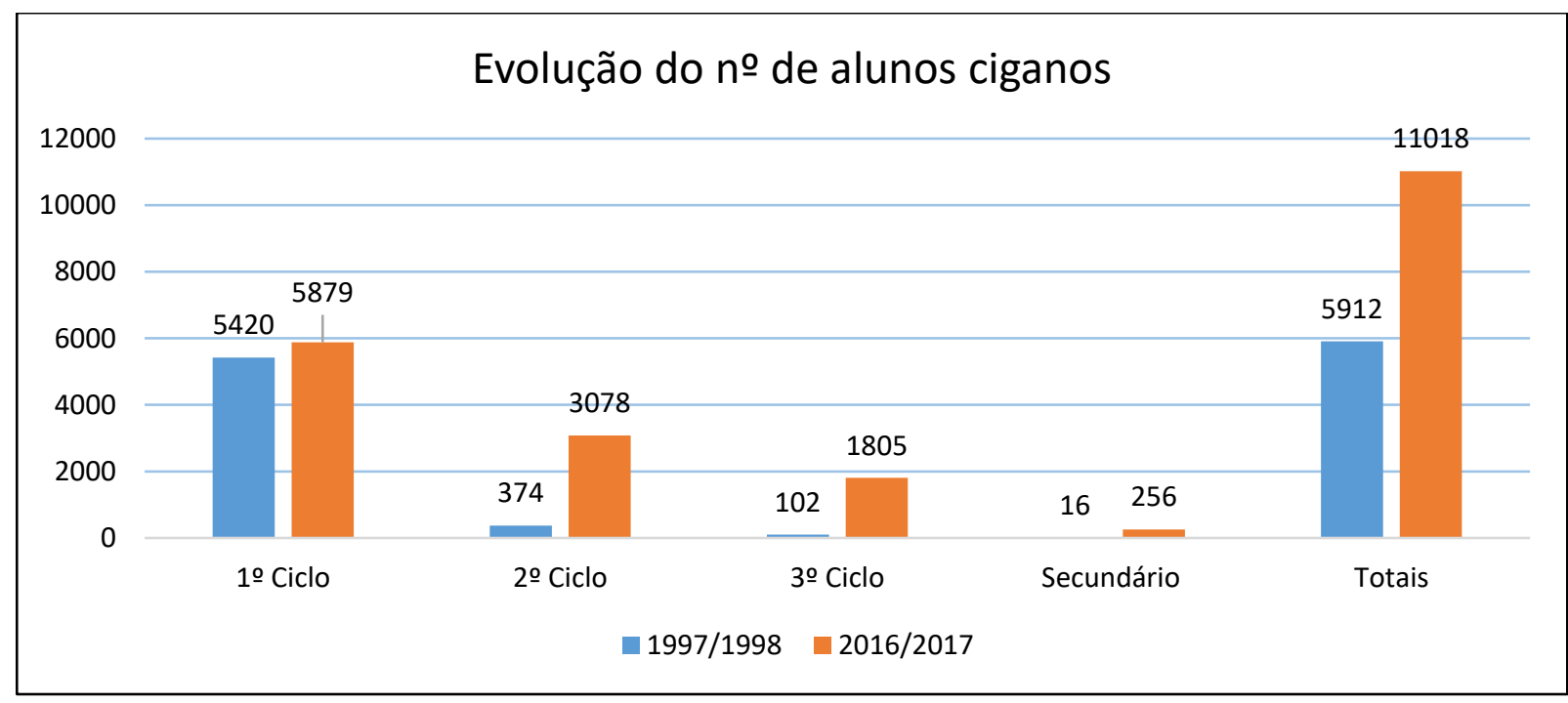

Fonte: Medinas, 2018

A comparação representada no gráfico 1 resulta da recolha de dados realizada pelo Ministério da Educação através de questionário eletrónico a todos os estabelecimentos de ensino no ano letivo 2016/2017 que foram comparados com o questionário anterior realizado no ano letivo de 1997/98. Os resultados obtidos demonstraram um incremento assinalável do número de estudantes ciganos a frequentar a escola. De 5912 alunos em 1998 passaram para 11018 em 2016/2017. Apesar de insuficiente, o número de alunos ciganos a frequentar a escola indica que "A mudança está a acontecer, ainda que devagarinho, dentro da população cigana portuguesa." (A. C. Pereira, 2018), sendo visível uma diferença geracional, em que os mais jovens são mais escolarizados do que as gerações anteriores (Mendes et al. 2014; Magano e Mendes, 2016).

\section{Metodologia}

Para a realização desta investigação foi adotada uma metodologia mista com a aplicação de um inquérito por questionário constituído por 62 perguntas e aplicado a 98 inquiridos ciganos residentes no concelho de Reguengos de Monsaraz. Para a análise estatística do questionário recorremos ao programa de análise estatística SPSS - Statistical Package for the Social Sciences, no qual foram codificadas 240 variáveis.

Aplicou-se também uma entrevista semiestruturada a quatro técnicos cuja atividade profissional no concelho se cruza com pessoas ciganas. As entrevistas foram posteriormente transcritas e analisadas pelo método de análise de conteúdo de Bardin. Utilizamos também a análise documental, ao pesquisar os livros de atas das reuniões de câmara do Município de Reguengos 
de Monsaraz, procurando identificar movimentações dos cidadãos Reguenguenses relativamente às pessoas ciganas. Fizemos também uma pesquisa bibliográfica inerente aos temas principais da nossa investigação - A Literacia Digital e as Pessoas Ciganas. Ainda sob a metodologia qualitativa surge a observação, como técnica que resulta do contacto do investigador com os entrevistados que na nossa investigação ocorreu aquando da aplicação dos questionários diretamente aos 98 inquiridos ciganos e também aos entrevistados não ciganos.

O nosso trabalho de campo decorreu entre setembro e outubro de 2017, tendo como suporte o contacto com uma pessoa cigana residente no Bairro da Pedra Escorregadia, que no lugar da sua residência amigavelmente nos recebeu e permitiu uma melhor aproximação à restante população.

\section{Ciganos de Reguengos de Monsaraz: caracterização sociodemográfica}

A maioria das pessoas ciganas de Reguengos de Monsaraz vive num local que se chama o Bairro da Pedra Escorregadia, conhecido pelo "Bairro dos Ciganos". Este bairro nasceu da necessidade de realojar as famílias ciganas que se encontravam acampadas em terrenos na periferia da cidade. A pressão urbanística e as queixas contra os ciganos, apresentadas nas reuniões da câmara municipal, levaram a que o município encontrasse um local para instalar essas pessoas. Os locais de residência das pessoas ciganas em Portugal são, na maioria das vezes, situados fora das povoações ou em zonas periféricas pouco qualificadas urbanisticamente, não sendo exceção nesta cidade.

O "bairro dos ciganos" encontra-se localizado no extremo exterior da zona industrial e é uma área desqualificada, do ponto de vista de equipamentos urbanos e sociais: sem acesso para entrada de viaturas através da estrada municipal, sem indicação nem sinalização de passagem de peões, não existe parque infantil ou outro equipamento de caráter sociai ou comercial, residem em contentores a que chamam habitações que são térreos e têm problemas de infiltrações - existem 14 “casas pré-fabricadas” e 14 barracas clandestinas.

Os inquiridos são bastante jovens verificando-se uma forte concentração nos grupos etários até aos 34 anos. Nessas faixas etárias encontramos 75,5\% dos inquiridos. O casamento ocorre em idades muito precoces, no grupo de inquiridos, obtivemos para os homens em média a idade de 18 anos e para as mulheres aos 16 anos, não obstante existirem casamentos com raparigas de 14 anos. As mulheres ciganas de Reguengos de Monsaraz são mães, em média, aos 18,6 anos, contrastando com as restantes portuguesas que são mães pela primeira vez aos 30,3 anos (Pordata, 2018). 
No que se refere à habitação, a maioria das pessoas ciganas vive em casas pré-fabricadas e barracas em péssimas condições, mesmo as casas do tipo clássica necessitam de obras e reparações. 53\% dos inquiridos refere problemas na zona onde vive: a drenagem de águas é referida por 39 pessoas; outros inquiridos salientam a ausência de parque infantil para as crianças que ali vivem (36 inquiridos); a ausência de sinalização de passagem de peões na única travessia de estrada é referida por 29 inquiridos; outros 29 salientam a presença de maus cheiros oriundos do matadouro que se encontra paredes meias com o Bairro da Pedra Escorregadia. Referidos com menos frequência, são identificados como problemas a ausência de contentores do lixo, 8 casos; a falta de acessos com 7 casos e 1 caso refere a ausência de comércio na zona.

Relativamente ao trabalho, os inquiridos que não se encontram na situação de estudantes, estão desempregados. Dos 75 respondentes adultos, apenas 5 responderam que não recebiam qualquer apoio financeiro, os restantes dependem do Rendimento Social de Inserção (RSI). Apesar de dependerem do RSI muitas pessoas ciganas para a sua sobrevivência, algumas vão fazendo trabalhos sazonais mas que são cada vez mais escassos, devido à mecanização das vindimas e da apanha mecânica da azeitona. Estas pessoas deparam-se cada vez com mais dificuldades de acesso a atividades remuneradas, comprovando que também neste contexto geográfico "ninguém dá emprego aos ciganos", tal como salientado por Pereira (2016). A dificuldade em exercer uma atividade remunerada não permite aos inquiridos prescindir da prestação do RSI uma vez que só com um trabalho minimamente estável, vontade que algumas pessoas ciganas nos transmitiram, seria possível prescindir desse apoio para a sobrevivência do dia-adia.

\section{Iliteracias literárias, profissionais e digitais}

De acordo com o Estudo Nacional sobre as Comunidades Ciganas (Mendes, Magano, \& Candeias, 2014) cerca de $30 \%$ da população cigana não tem o $1^{\circ}$ ciclo completo, nem nunca frequentara a escola. Muitas são as causas desta situação, que vão desde as questões culturais às situações impostas de forma visível ou invisível pela sociedade maioritária. Muitas raparigas são retiradas do ambiente escolar quando é atingida a puberdade para tratarem da casa, casarem ou simplesmente para não conviverem de perto com os não ciganos. Quase $40 \%$ dos inquiridos não sabe ler nem escrever e muitos dos que sabem, fazem-no mal. Os rapazes ciganos abandonam a escola por esta não constituir um objetivo de vida e não a veem como um fator de acesso a uma vida melhor e de inclusão. Noutros casos o abandono deve-se ao início de uma vida de adulto junto da família (uniões conjugais precoces). $\mathrm{O}$ aumento do $\mathrm{n}^{\mathrm{o}}$ de alunos ciganos nas escolas surge, não só pela aplicação de políticas públicas, como por exemplo na sequência da 
exigência nos critérios de atribuição do RSI, cujos planos de inserção implicam a realização de escolarização e de formação profissional por parte de quem não a detém, mas tal como o Estudo Nacional sobre as Comunidades Ciganas (Mendes et al., 2014) e outros estudos (Magano e Mendes, 2016) revelam, existem mudanças sociais nos hábitos das pessoas ciganas, nomeadamente um maior interesse pela escola e pelo cumprimento da escolaridade obrigatória, assim como uma maior frequência de creches e jardins-de-infância, sendo que as crianças e jovens frequentam a escola massivamente no $1^{\circ}$ ciclo, aumentando o absentismo e abandono escolar a partir do $2^{\circ}$ e $3^{\circ}$ ciclo de escolaridade e diminuem as matrículas significativamente no ensino secundário (ver dados da DGEEC).

A população alvo do nosso estudo apresenta um elevado nível de analfabetismo, dos 98 inquiridos, 38\% (37 indivíduos) não sabem ler nem escrever e 62\% (61 indivíduos) responderam que sabiam ler e escrever. No grupo de pessoas que não sabem ler nem escrever, verificouse a existência de diferenças de género significativas, pois são as mulheres quem em maior número não sabem ler nem escrever com o valor de $68 \%$, ao passo que os homens representam $32 \%$ do grupo. Relativamente às pessoas que sabem ler e escrever essa diferença de género não é significativa, sendo $48 \%$ de mulheres e $52 \%$ homens. Apenas as gerações mais novas até ao grupo etário 30-34 anos sabem ler e escrever, nos grupos etários de idades superiores apenas 1 pessoa diz saber ler e escrever, o que demonstra claramente a desvalorização dada à escolaridade.

Dos 98 inquiridos, 52 frequentaram a escola, 39 (75\%) abandonaram os estudos antes de terminarem o ano letivo que frequentavam. Constatámos que a maioria dos abandonos escolares ocorreu no $1^{\circ}$ ciclo de estudos com uma percentagem de abandono de $83 \%$. O ciclo de estudos que frequentaram de maior nível foi o $3^{\circ}$ ciclo, nenhum dos inquiridos frequentou o ensino secundário nem o universitário. No geral, a percentagem de abandono foi de $75 \%$.

Os trabalhos tradicionalmente realizados por ciganos, como a criação e comercialização de gado muar, venda de tecidos, vendas nos mercados e feiras ou cestaria, encontram-se praticamente extintos ou em vias de desaparecerem completamente. Os fatores, baixas competências profissionais e a extinção das atividades tradicionais, conjugam-se para empurrarem as pessoas ciganas para um maior isolamento relativamente ao mundo do trabalho, remetendo-os para a situação de desempregados o que para os nossos inquiridos se verificou na totalidade.

\section{O acesso e uso de equipamentos tecnológicos digitais}

Os resultados obtidos no estudo mostram que dos 98 inquiridos, 50 possuem telemóveis e 48 não. Dos que responderam positivamente, 34 são Smartphones com acesso à internet, 12 são 
telemóveis simples e 2 são Smartphones sem acesso à internet. Os inquiridos que não possuem telemóveis são maioritariamente constituídos por mulheres. Atendendo a que em Portugal existiam em 2016, 19.927.577 equipamentos de utilizadores do serviço móvel (Pordata, 2018), o grupo estudado está percentualmente abaixo do valor nacional que é superior a $90 \%$.

Relativamente a equipamentos informáticos, dos 98 inquiridos apenas 15 dizem possuir computadores, o que ilustra claramente uma situação de "fratura digital" na posse e consequentemente utilização frequente de computadores. No entanto, não ter um computador na habitação não significa que as pessoas ciganas não utilizem computadores. Dos 98 inquiridos, 51 dos casos afirmam já terem utilizado um computador para realizar alguma tarefa. Os locais de acesso a computadores são: Os Espaços Internet do concelho de Reguengos de Monsaraz são referidos por 36 inquiridos; o Programa Escolhas através do Centro de Inclusão Digital é referido por 18; a escola com 15 casos, o sendo único local onde alguns inquiridos disseram ter tido acesso a um computador. Em casa são 15 os inquiridos que dizem ter acesso a computador. Os espaços de acesso público a computadores (Espaços Internet e CID) são a única oportunidade de acesso às tecnologias por parte de algumas pessoas ciganas.

Para se perceber o domínio da linguagem informática e digital criámos um grupo de palavras com termos genéricos amplamente utilizados nas tecnologias de informação, relativos a hardware, sistemas operativos e software, para que os inquiridos pudessem indicar os termos de que conhecem o significado. No grupo de palavras relativas aos componentes físicos de um computador os inquiridos que utilizam computadores, 32 conhecem a expressão "wifi", 32 conhecem o termo "formatar", 22 sabem o que é um "disco", 10 inquiridos conhecem o termo "Ram", apenas 6 reconhecem o principal componente de um computador a "motherboard" e apenas 3 dizem saber o que significa "RJ45". Relativamente a sistemas operativos, denunciam pelas frequências da resposta um conhecimento muito vago de computadores pois apenas 20 dos inquiridos referem conhecer o termo "Windows" que é o sistema operativo mais utilizado no mundo, e apenas 3 dizem conhecer o termo "Linux" que é um sistema operativo "Open Source" de utilização livre sendo muito utilizado em servidores.

No grupo de palavras destinado à perceção do conhecimento de software de utilização generalizada, instalado em praticamente todos os computadores pessoais, verificámos que o termo "email" é o mais conhecido, sendo referido 45 vezes, seguindo-se o termo "antivírus" referido 29 vezes. Os programas de produtividade do pacote "Office" são pouco conhecidos pelos Reguenguenses ciganos, pois apenas o "Power Point" e o Word são referidos 14 vezes, o "Acess" e "Excel" apenas 7. O "Movie Maker" é um software gratuito nativo de todas as versões Windows antes da versão 10, é referido apenas por 7 inquiridos. O termo "browser" que se refere a 
um software que permite aceder e fazer pesquisas na internet, é utilizado por todos os inquiridos que utilizam computadores, mas o conhecimento do conceito é referido somente por 5 pessoas.

Com o último grupo de palavras pretendemos conhecer se os nossos inquiridos tinham familiaridade com alguns suportes de dados e palavras vulgarmente utilizadas em vários equipamentos tecnológicos. Neste grupo o DVD foi o mais referido com 51 inquiridos, seguindo-se o CD com 41, depois, Pen com 39. A palavra rede e password foram referidas 36 vezes. As expressões mais conhecidas dos inquiridos são as mais generalistas referindo-se a objetos físicos com os DVDs, CDs ou PenDrive, suportes de dados utilizados em diversos equipamentos tecnológicos. Termos relativos a software e hardware são pouco conhecidos dos inquiridos. A baixa familiaridade com conceitos básicos relacionados com a utilização de computadores indicia uma utilização incipiente e baseada em atos mecânicos e repetitivos, não alicerçados em conhecimentos técnicos mínimos.

De uma maneira geral chamamos internet à World Wide Web, criada em novembro de 1990 por Timothy John Berners-Lee, físico britânico (Castells, 1999). O criador da web desenvolveu o primeiro browser ou navegador, trata-se de uma ferramenta de software que permite a visualização das páginas web. É através do browser ou navegador que indicamos ao computador as páginas que pretendemos consultar (ex: www.sapo.pt).

A World Wide Web mais conhecida por www ou web, é um sistema de documentos alojados em diversos computadores em hipertexto, ou seja, textos que contêm links que podem levar à consulta de outros documentos noutra zona do documento ou direcionar o cibernauta para um computador em qualquer outro lado do mundo.

Os nossos inquiridos, quando questionados se já tinham ouvido falar da internet 60,2\%, indicam ouvir falar muitas vezes, 37,8\% dizem ter ouvido falar algumas vezes, do que concluímos que a esmagadora maioria dos inquiridos ouve falar da internet.

Relativamente à frequência (gráfico 2) com que usam a internet, 25 inquiridos afirmam utilizar a Internet todos ou quase todos os dias, sendo que 15 dizem fazê-lo pelo menos uma vez por semana e 11 pelo menos uma vez por mês mas 4 inquiridos dizem utilizar a Internet menos de uma vez por mês e 43 afirmam nunca utilizar a internet. 
Gráfico 2: Frequência de utilização da Internet

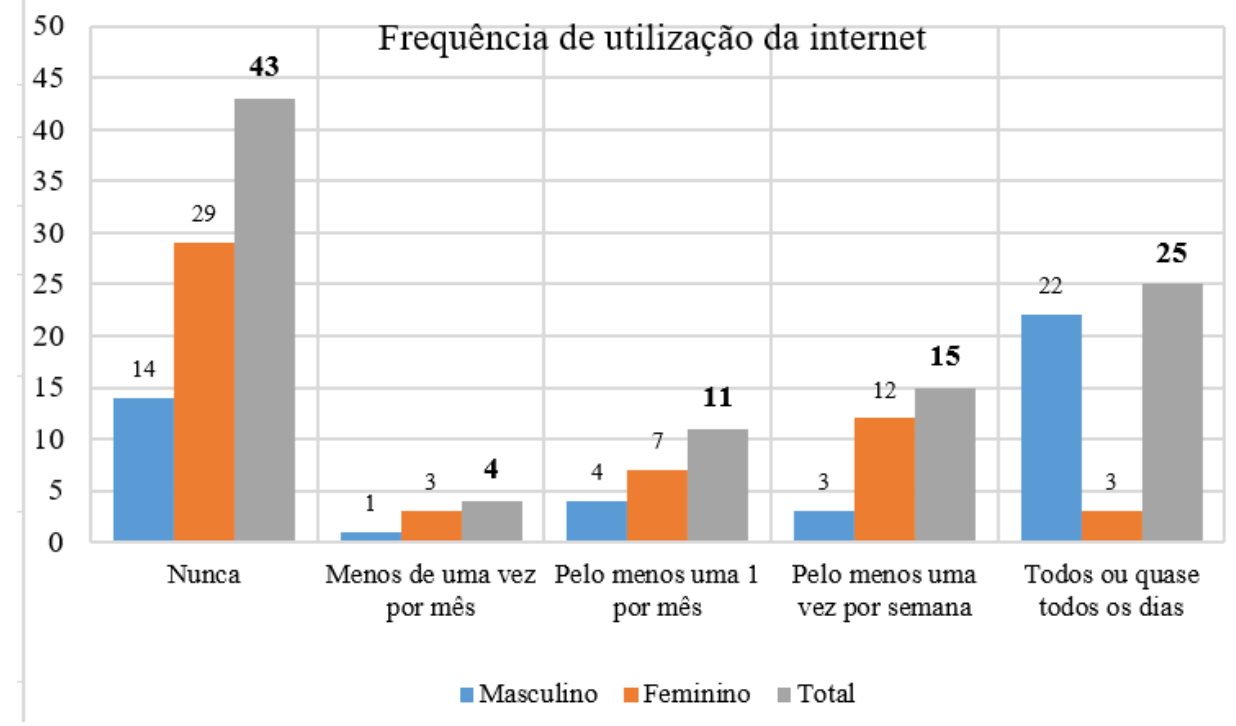

Fonte: Medinas, 2018

Os participantes no estudo que dizem nunca utilizar a internet são a maioria dos inquiridos. Se juntarmos a este grupo as pessoas que raramente o fazem, como é o caso dos que a utilizam menos de uma vez por mês ou uma vez por mês, constatamos que cerca de $60 \%$ dos inquiridos não utiliza a internet.

No que se refere à diferenciação de género, as mulheres ciganas são excluídas de forma multidimensional da vida social e económica, sofrendo discriminação intersecional onde ser mulher e ser cigana se conjugam para múltiplas formas de discriminação de etnicidade e género (Magano, 2017). Esta diferença de género no acesso às tecnologias e à sua utilização é evidenciado.

Trabalhámos ainda os resultados da utilização da internet por grupos etários que foram comparados com os valores para o país constatando-se que existe uma profunda fratura digital entre a sociedade maioritária e a dos excluídos e subalternos. O grupo etário do 15 aos 24 anos apresenta 59\% de utilizadores de internet enquanto o valor nacional obtido no Pordata é de 99\%, o grupo etário dos 25 aos 34 anos nos ciganos inquiridos apresenta 50\% contra os 97\% nacionais. A partir deste grupo etário, entre os mais velhos, nenhum dos nossos inquiridos é utilizador da internet, situação que também vai de encontro ao elevado nível de analfabetismo coincidente com a não utilização da internet. 
Gráfico 3. Expressões conhecidas sobre uso de Internet

Expressões conhecidas sobre Internet
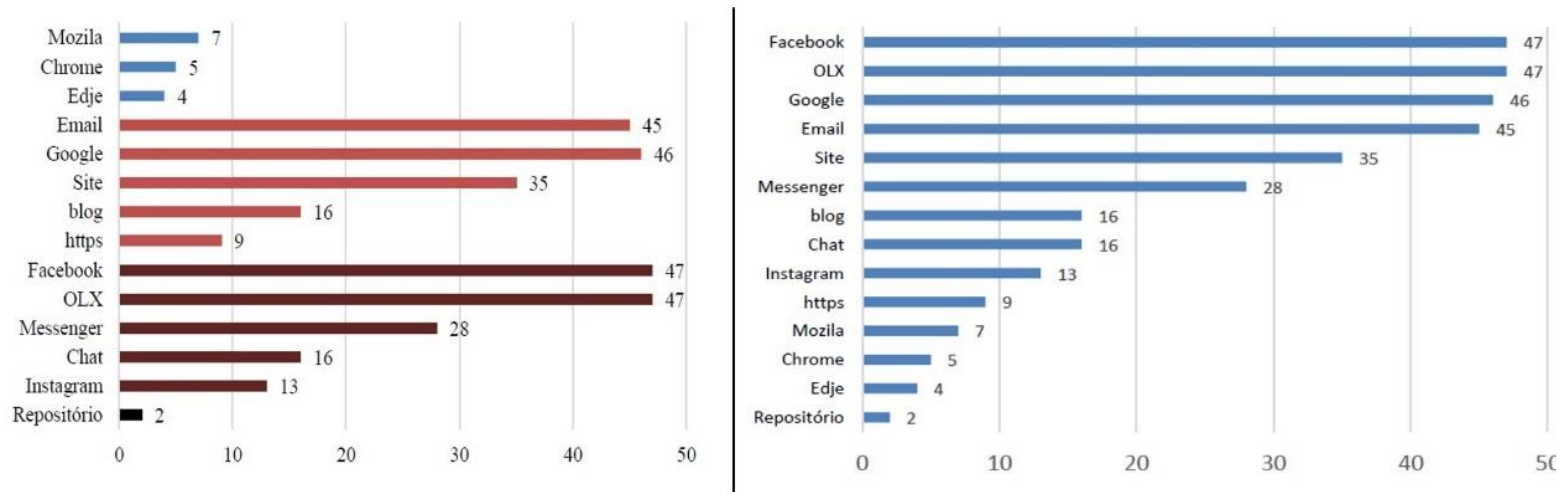

Fonte: Medinas, 2018

Procurámos conhecer a familiaridade que os residentes ciganos em Reguengos de Monsaraz tem sobre termos usados frequentemente relativamente à internet (gráfico 3). Da lista de termos escolhidos dividimo-los em grupos: browsers, termos genéricos da internet e redes sociais. Colocámos ainda um termo usado menos frequentemente, "repositório", tentando perceber se algum dos inquiridos tinha alguma experiência em download e upload de ficheiros. Os resultados obtidos mostram que os inquiridos embora possam utilizar browsers diferentes, não os sabem identificar nem reconhecer como sendo um software específico para o acesso à internet. Dos 55 inquiridos que disseram utilizar a internet 7 dizem que conhecem o Mozzila, 5 conhecem o Chrome e 4 conhecem o Edje. No grupo de termos genéricos, a palavra "Google" é conhecida de 47 dos nossos inquiridos, devido principalmente por ser a homepage da maioria dos computadores utilizados nos espaços de acesso público à internet. Segue-se o termo "email” com 45, depois o termo "site" com 35, "blog" com 16 e "HTTPS" sigla em inglês de Hyper Text Transfer Protocol Secure, que em português significa "Protocolo de Transferência de Hipertexto Seguro" com 9 inquiridos. Nas redes sociais, o termo "Facebook" é o mais conhecido dos inquiridos sendo referido por 47 pessoas. O "Messenger" é referido por 28 e o termo "chat" por 16 . Neste grupo englobamos o site "OLX" que revelou a par do Facebook ser a expressão mais conhecida dos nossos inquiridos.

Colocando no gráfico os resultados obtidos por ordem decrescente constatamos que os inquiridos dizem conhecer termos que já entraram conhecimento geral e que correspondem também aos termos utilizados pelos inquiridos na sua relação com as tecnologias digitais, tais como Facebook, Olx, Google, email, site e Messenger. Inquirimos ainda sobre os sites que visitavam quando estavam na web. 
Gráfico 4: Finalidades de uso de Internet

Utilização da Internet

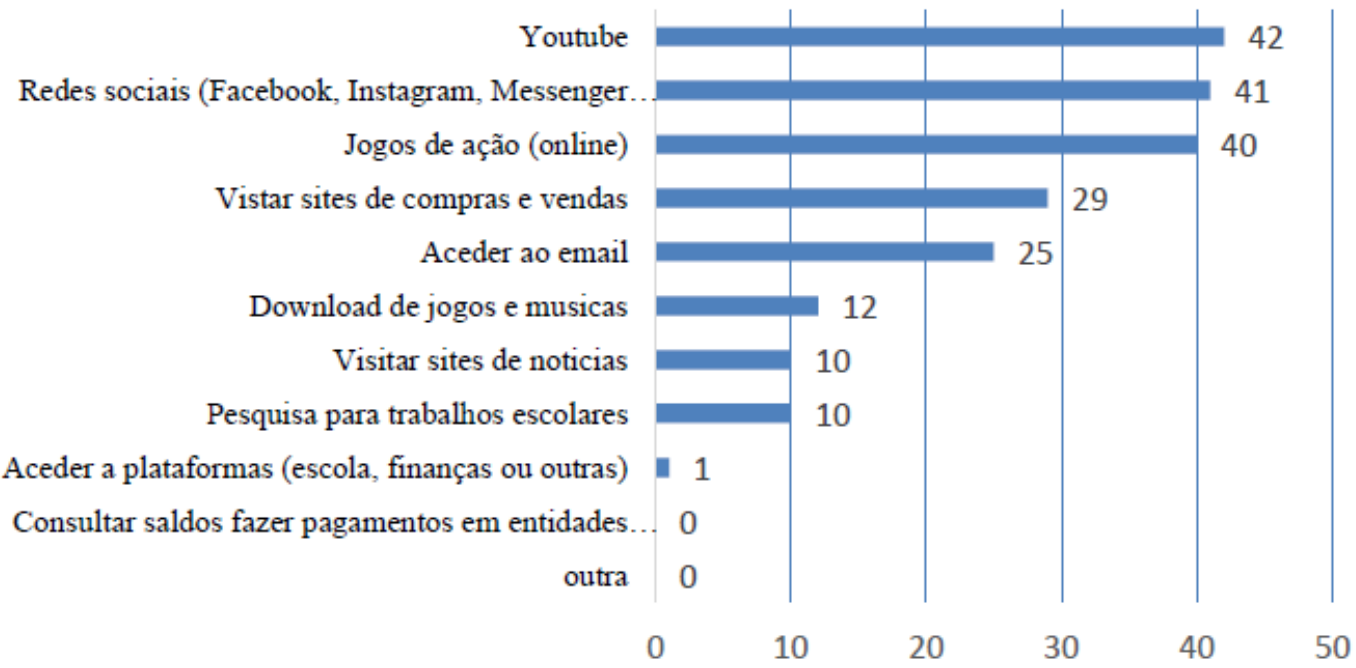

Fonte: Medinas, 2018

Da lista de opções disponível é o Youtube o site mais visitado pelos inquiridos, seguem-se as redes sociais, depois os jogos e em seguida surgem os sites de compras e vendas, consultar o email, depois com o mesmo número de inquiridos a referirem o download de jogos e música e a pesquisa para trabalhos escolares. Os sites com caraterísticas de serviços online onde é necessária uma interação com instituições, não são conhecidos ou não são utilizadas pelos nossos inquiridos (gráfico 4).

A metodologia mista que aplicámos no nosso estudo permitiu-nos não só a confirmação dos resultados obtidos pelo inquérito por questionário, mas também proporcionou outras leituras das atividades efetuadas online pelos inquiridos, que não teriam sido possíveis exclusivamente pelos questionários.

É o caso dos utilizadores das plataformas online de compras e vendas, que as utilizam como substituição dos meios tradicionais de comércio presenciais, ou seja, as pessoas ciganas apesar das suas dificuldades encontram no ciberespaço um meio de perpetuar as suas formas de ocupação tradicionais, como é relatado pelos entrevistados. Os monitores dos espaços internet percecionam que os utilizadores procuram nos sites de compras e vendas, concretizar diversos negócios que lhes permita obter algum rendimento, tais como a compra e venda de viaturas. Para as raparigas o interesse negocial é relativo a produtos de beleza e saúde. As diferenças geracionais também são percetíveis no tipo de pesquisas que fazem. Os entrevistados observam que os homens adultos têm um grande interesse pelo tema "automóveis" quer para negociação quer para observação e características técnicas. Os rapazes têm especial interesse por jogos, o 
Facebook e a música. As raparigas ciganas, por sua vez, o que mais procuram são produtos de beleza, maquilhagem, pinturas, e utilizam o Youtube para fazer essas visualizações.

Apenas 15 inquiridos possuem computador próprio, mas são 51 os que dizem já ter utilizado um computador pelo menos uma vez e 40 inquiridos utilizam regularmente a internet. Os locais onde têm acesso e utilizam a internet são para a maior parte dos inquiridos os espaços públicos de acesso à internet: os Espaços Internet e o espaço CID (Centro de Inclusão Digital) do Programa Escolhas ${ }^{3}$. São nestes locais que os ciganos jovens e menos jovens têm acesso livre e gratuito aos equipamentos e internet, sendo também nestes locais que são visíveis algumas fragilidades dos utilizadores referidas pelos entrevistados. Os mais referidos foram: ligar e encerrar adequadamente os computadores, aceder e pesquisar na internet, fazer impressão de documentos, enviar, receber e interpretar emails.

Os locais públicos de acesso livre à internet são têm utilização igual por homens e mulheres, as diferenças de género mantêm-se também no acesso ao mundo digital. A liberdade das raparigas é menor que a dos rapazes, as restrições vão desde o acesso ao próprio espaço até ao acesso do Facebook. Os entrevistados referiram que os rapazes têm liberdade em frequentar os espaços internet sem restrições, mas as raparigas não têm essa liberdade de ação,

E1- (...) eu noto é que os pais não deixam que as filhas, meninas irem ao espaço internet, vão sempre às escondidas, principalmente do pai, a mãe deixa.

(Mulher, 56 anos)

Discriminação, preconceito e racismo estão em todo o lado e são também detetados pelos entrevistados nos Espaços Internet, relatando que quando utentes ciganos frequentam e utilizam os espaços internet, os não ciganos deixam de utilizar esses espaços. Este abandono do espaço que é pública e de livre acesso pode ser assim transformado num espaço de segregação por ação racista.

E1-Se às vezes vão lá pessoas, veem ciganos, e voltam para trás. E pronto, não querem estar ao pé deles (...) chegam lá, veem que há ciganos, não querem. Não querem. E pronto. (...) eles não querem estar com os ciganos! É muito triste, é uma discriminação que não devia haver (...) mas realmente se chegar lá alguém e vir os ciganos, voltam as costas.

(Mulher, 56 anos)

\footnotetext{
${ }^{3}$ O Escolhas é um programa governamental de âmbito nacional, criado em 2001, promovido pela Presidência do Conselho de Ministros e integrado no Alto Comissariado para as Migrações - ACM, IP, cuja missão é promover a inclusão social de crianças e jovens de contextos socioeconómicos vulneráveis, visando a igualdade de oportunidades e o reforço da coesão social. (https://www.programaescolhas.pt/apresentacao)
} 
As baixas competências de leitura e escrita constatadas no estudo quantitativo pela maior parte dos inquiridos, é confirmada pelas dificuldades sentidas pelos utilizadores dos Espaços Internet, que relatam que muitos utilizadores "mal sabem escrever o nome" e têm muitas dificuldades em ler e interpretar qualquer texto, tornando por exemplo a criação de um texto para um email uma tarefa para a qual precisam de ajuda.

De acordo com Gilster, literacia digital consiste na "habilidade de entender e utilizar a informação de múltiplos formatos e proveniente de diversas fontes quando apresentada por meio de computadores." (Gilster, 1997: 1), pressupõe que a informação apresentada através de computadores e da internet deve ser compreendida e utilizada de uma forma consciente e critica. A abissal quantidade de informação que chega aos internautas deve ser necessariamente escrutinada e criticamente reflexiva, conhecendo as fontes de informação, validando conteúdos e confirmando-os em diversos sites. O conceito definido por Gilster privilegia um pensamento crítico, como a avaliação crítica dos conteúdos da internet e não tanto as competências técnicas de manuseamento dos equipamentos.

A internet é aberta ao mundo, mas não acessível a todos os seus habitantes (Sanou, 2016), é uma rede de redes onde os utilizadores podem colocar conteúdos e interagirem uns com os outros, formando uma rede umbilicada de nós e de relações, espelhando a sociedade mundial. Como tal, também existem lados obscuros, falamos da criminalidade informática, da manipulação e informação errada ou fake news. Os nossos inquiridos consideram que a veracidade da informação vinda da internet depende do site consultado (53\%), mas $27 \%$ consideram que tudo o que está na internet é confiável, $11 \%$ não confiam na informação da internet e $9 \%$ consideram que a informação deve ser validada noutros sites e por diferentes autores. Não será alheio a esta postura as notícias diárias amplamente difundidas nos média relatando fraudes informáticas.

Procurámos também saber se os nossos inquiridos tinham o hábito saber as notícias diárias. Dos 61 inquiridos que dizem saber ler e escrever, 38 dizem não ler jornais e 15 inquiridos dizem consultar os jornais online e 8 inquiridos dizem ler o jornal impresso. $\mathrm{O}$ elevado analfabetismo dos inquiridos, agravado pela falta de hábitos de leitura continua a ser um fator de distanciamento da sociedade maioritária, sociedade onde a informação é o motor que alavanca essa mesma sociedade. 


\section{Gráfico 5: Utilização dos Média}

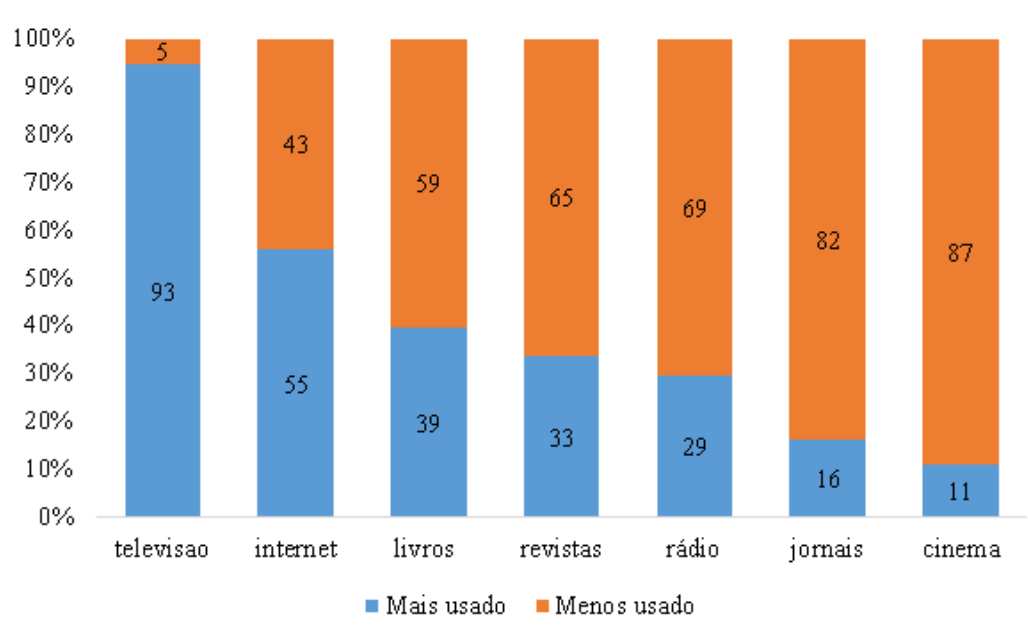

Fonte: Medinas, 2018

Os meios de comunicação social (gráfico 5) mais utilizados pelos inquiridos são a televisão (93) (só quem está de luto é que não vê televisão ou quem não tem eletricidade); em segundo lugar, surge a utilização da internet, com 55 inquiridos a afirmá-lo; em todos os restantes itens como rádio, jornais impressos, revistas impressas, livros, cinema em sala, os inquiridos responderam maioritariamente que raramente ou nunca os utilizavam. O meio menos utilizado é a frequência de cinema em sala uma vez que 87 inquiridos responderam que não têm esse hábito. As redes sociais encontram-se em segundo lugar nas preferências dos nossos inquiridos na utilização da internet. Relativamente ao tipo de utilização e aos possíveis perigos de exposição que estas redes representam para crianças e jovens, os entrevistados permitiram-nos percecionar que a exposição a que as crianças e jovens ciganos estão sujeitos, é um tanto mitigada pelo facto da maioria do círculo de "amizades" se circunscrever a outros jovens ciganos e a outras pessoas que conhecem.

Se as interações pessoais nas redes sociais devem ser de facto realizadas em condições de segurança, pois os cibernautas podem escolher uma identidade ou muitas identidades para si próprios com possíveis fins criminosos, a informação guardada nos computadores e plataformas online deve ser salvaguardada, competindo a cada cibernauta proceder as essas ações de segurança. Nesse sentido, os inquiridos revelaram desconhecimento de regras mínimas de segurança e de proteção de dados pessoais. Os resultados obtidos sobre este tema resultam não só das respostas às questões colocadas, mas também do contato estabelecido com cada um dos inquiridos uma vez que os questionários foram preenchidos pelo próprio investigador. As perceções sobre as questões de segurança informática são também identificadas pelos entrevistados, que consideram que a maioria dos utilizadores não conhece minimamente regras de segurança informática nem cuidados de navegação na internet, nomeadamente a utilização de palavras 
passe. A maioria dos inquiridos considera ser muito importante que os seus filhos saibam utilizar computadores e internet, 70,9\% dos inquiridos têm perceção muito positiva acerca da utilização da internet, 26,6\% têm perceção positiva, os dois grupos com perceção positiva perfazem $97,5 \%$ dos 79 respondentes.

\section{Conclusão}

A atual sociedade baseada no processamento da informação depara-se com a necessidade de aceder a computadores e de saber utilizá-los. As tecnologias digitais vieram trazer a muitas pessoas mais um fator de divisão e consequentemente de discriminação a camadas da população mais desfavorecida, a referida fratura digital, que coloca estas pessoas ma situação de infoexclusão (Castells, 2007), quanto ao acesso à sociedade de informação e ferramentas digitais. No que se refere aos resultados desta investigação, para estes inquiridos esta situação de infoexclusão é mais uma forma de exclusão, colocando-os numa situação de múltipla exclusão, digital, social, económica, cultural, etc. A exclusão digital acontece pelo não acesso ao conhecimento e às novas tecnologias, a exclusão social e económica pela falta de acesso ao trabalho e ao rendimento, levando-os ao círculo vicioso da dependência do estado mas também a segregação espacial e relacional (Medinas, 2018). No entanto, os ciganos de Reguengos de Monsaraz têm a perceção que é necessário saber lidar com as tecnologias digitais, embora não tenham noção do que é possível fazer com a tecnologia: sabem que não saber estar nesse mundo digital é mais uma discriminação que se junta a outras.

Um dos espaços em que decorreu este estudo, o Bairro da Pedra Escorregadia é um bairro isolado, situado junto a uma estrada Municipal de Reguengos de Monsaraz à qual apenas existe acesso pedestre. Visitar o bairro é uma experiência de viagem no tempo, parecendo que recuámos dezenas de anos para um lugar que não é de um país civilizado do século XXI. A habitação é de forma geral degradada e desadequada à dimensão do agregado familiar, outros vivem em barracas sem eletricidade e água. Nenhum dos inquiridos tem um emprego, nem nunca teve, dependem do Rendimento Social de Inserção (RSI), situação preocupante pois trata-se de uma ou duas gerações que não têm qualquer experiência de trabalho, nem existem esses modelos de referência nas famílias, tal como acontece em outras localidades de Portugal (Santos, 2013; Pinto, 2017)

O grupo de inquiridos possui uma da baixa escolarização (o nível de escolarização não ultrapassa o $9^{\circ}$ ano e só uma pessoa o realizou) e o abandono escolar é de $75 \%$. Com idade superior a 35 anos apenas uma pessoa sabe ler e escrever e nível de analfabetismo é de 38\%. Poucas 
pessoas possuem computadores, alguns procuram os espaços internet para acederem a computadores e à internet. Nestes espaços tratam de assuntos pessoais, lazer ou negócios. Mas deparam-se com muitas dificuldades no uso dos equipamentos informáticos mesmo para tarefas básicas com relatam os monitores dos espaços internet.

Utilizam os computadores para acederem redes sociais e acervos de vídeos do Youtube, por parte dos inquiridos mais jovens. Os mais velhos veem-se confrontados com a necessidade de utilizar as tecnologias digitais para concretizar situações da vida quotidiana, esbarrando nas suas baixas competências de leitura e escrita.

Praticamente todos os inquiridos têm o hábito de ver televisão, seguindo-se a internet. Os meios audiovisuais cuja utilização exige a leitura são pouco ou nada utilizados. Nas redes sociais procuram manter as suas interações com pessoas ciganas conhecidas. A segurança de dados e equipamentos não é ainda uma preocupação para os internautas do grupo estudado.

O Olx (compras e vendas) é um dos sites mais utilizados pelos inquiridos indiciando uma eventual tentativa de mudança do espaço de negócio, de transações tradicionais em feiras e mercados para transações mediadas por meios digitais.

Os problemas habitacionais aliados a baixas competências de leitura e escrita assim como falta de competências profissionais condicionam as pessoas ciganas inquiridas em todos os aspetos da vida social, e que também afetam a sua literacia digital, que fica circunscrita a uma utilização básica e superficial, longe de poderem estabelecer interações com os diversos serviços municipais, governamentais, banca, educação ou outros que cada vez mais procuram encerrar espaços físicos e substitui-los por formas digitais de interação.

O quadro de vida em que estas pessoas residem exige uma intervenção pública através de políticas sociais estruturais que tenham impacto em dimensões como habitação, educação e emprego para que o grupo estudado possa aumentar o seu grau de "literacias" em igualdade de circunstâncias com a sociedade maioritária de modo a evitar novos cenários de exclusão. 


\section{Bibliografia}

Ala-Mutka, K. (2011). Mapping digital competence: towards a conceptual understanding. Institute for Prospective Technological Studies, 60. Obtido de http://ipts.jrc.ec.europa.eu/publications/pub.cfm?id=4699.

ANACOM. (2016). O consumidor de comunicações eletrónicas 2015. (1-158).

Bastos, J., Correia, A. C., \& Rodrigues, E. (2007). Sintrenses Ciganos - Uma abordagem estrutural-dinâmica. Lisboa: CM de Sintra e ACIDI.

Castells, M. (1999). A Era da Informação: Economia, Sociedade e Cultura. V 1 A Sociedade em Rede. São Paulo: Paz e Terra.

Castells, M. (2007). A galaxia da Internet (2a edição). Lisboa: Fundação Calouste Gulbenkian.

Gilster, P. (1997). Digital Literacy. San Francisco, CA: John Willey \& Sons.

Liégeois, J. P. (1989). Ciganos e Itinerantess: Dados socioculturais. Dados sociopoltticos. Lisboa: Santa Casa da Misericórdia de Lisboa.

Magano, O. (2010). Tracejar vidas normais- Estudo qualitativo sobre a integração social de indivíduos de origem cigana na sociedade portuguesa. (Tese de Doutoramento, Universidade Aberta, Lisboa, Portugal).

Magano, O. (2017). Mulheres Ciganas, Desigualdade de Género e Discriminação na Sociedade Portuguesa. In Sofia Neves e Dália Costa (Coord.)Violências de Género. Lisboa. Centro Interdisciplinar de Estudos de Género. Coleção estudos de Género. 153-187.

Magano; O. e Mendes, M. M. (2016). «Constrangimentos e oportunidades para a continuidade e sucesso das pessoas Ciganas», Configurações, $18 \mid 2016$, consultado a 26 de setembro. URL : http://configuracoes.revues.org/3546; DOI : 10.4000/configuracoes.3546. 8-26.

Medinas, C. B. (2018). Ciganos e Literacia Digital: Estudo de caso em Reguengos de Monsaraz (Dissertação de Mestrado Universidade Aberta, Lisboa, Portugal). Obtido de http://hdl.handle.net/10400.2/7659.

Mendes, M., Magano, O., \& Candeias, P. (2014). Estudo nacional sobre as comunidades ciganas. Lisboa: ACM.

Neto, F. (2004). Psicologia Social Aplicada. Lisboa: Universidade Aberta.

Nunes, O. (1996). O Povo Cigano (2. ${ }^{\mathrm{a}}$ ed.). Edição do Autor de parceria com a Obra Nacional da Pastoral dos Ciganos.

Pereira, A. C. (2018, Abril 9). Em 19 anos duplicou o número de ciganos na escola obrigatória. Público. Obtido de https://www.publico.pt/2018/04/09/sociedade/noticia/quase-duplicou-o-numero-dealunos-ciganos-na-escola-obrigatoria-1808751. 
Pereira, I. (2016). Ninguém dá trabalho aos ciganos! - Estudo qualitativo sobre a (des)integração dos ciganos no mercado formal de emprego. Dissertação de mestrado,Universidade Aberta,Lisboa,Portugal.

Pinto, P. C. S. (2017). O Terceiro Bairro. Estudo qualitativo sobre o impacte do rendimento social de inserção nos modos de vida de pessoas ciganas. Dissertação de Mestrado em Intervenção Social, Inovação e Empreendorismo. Coimbra: Faculdade de Psicologia e Ciências da Educação e Faculdade de Economia, Universidade de Coimbra.

Pordata. (2017). Taxa de analfabetismo segundo os Censos: total e por sexo. Obtido de https://www.pordata.pt/Portugal/Taxa+de+analfabetismo+segundo+os+Censos+total+e+p or+sexo-2517.

Pordata. (2018). No telemóveis. Obtido 25 de Janeiro de 2018, de https://www.pordata.pt/DB/Portugal/Ambiente+de+Consulta/Tabela.

Sanou, B. (2016). ICT Facts and figures 2016. ITU Telecommunication Development Bureau, 1-8. Obtido de https://www.itu.int/en/ITU-

D/Statistics/Documents/facts/ICTFactsFigures2016.pdf.

Santos, S. A. (2013). O Rendimento Social de Inserção e os Beneficiários Ciganos: o caso do concelho de Faro. Faro: Universidade do Algarve. Dissertação de Mestrado em Educação Social.

Silva, M. C. (2008). Desigualdade, pobreza e exclusão: o caso português. inTorres A. e Batista L. (Org.). Em Sociedades Contemporâneas: reflexividade e Acão. Porto: Edições Afrontamento. 



\title{
Capítulo 7.
}

\section{Perceções dos estudantes ciganos e dos técnicos dos projetos Escolhas sobre as trajetórias escolares de continuidade ao nível do ensino secundário}

\author{
BRUNO BAPTISTA \\ Mestre em Sociologia pelo Iscte \\ bruno.m.s.baptista@gmail.com \\ MaRia MANUEla MENDES \\ Professora e Investigadora, Iscte - Instituto Universitário de Lisboa, Centro de Investigação e Estudos de Sociolo- \\ gia (CIES-Iscte) e FAUL, Universidade de Lisboa, Lisboa, Portugal \\ mamendesster@gmail.com
}

Resumo: Neste texto apresenta-se uma análise em que se procura confrontar as perceções dos estudantes ciganos e as dos coordenadores e técnicos dos projetos Escolhas sobre as trajetórias escolares de continuidade no ensino secundário por parte dos alunos ciganos na Área Metropolitana de Lisboa. Neste contexto e tendo por base uma análise exploratória de pendor qualitativo, analisam-se principalmente as perceções sobre os fatores motivadores e desmotivadores para a continuidade escolar, mas também os obstáculos, principais impactos, assim como, as dificuldades e desafios que se colocam no plano da intervenção social. Os dados que suportam esta análise foram recolhidos através de 18 entrevistas semi-diretivas a alunos ciganos inscritos no ensino secundário e entrevistas realizadas a técnicos e coordenadores de 5 projetos Escolhas localizados na Área Metropolitana de Lisboa

Palavras-chave: Projectos Escolhas; perceções; Ciganos, trajetórias escolares

\begin{abstract}
This text presents an analysis that seeks to confront the perceptions of Roma students and those of the coordinators and technicians of the Escolhas projects on the school trajectories of continuity in secondary education by Roma students in the Lisbon Metropolitan Area. In this context and based on an exploratory qualitative analysis, perceptions about the motivating and demotivating factors for school continuity are analyzed, but also the obstacles, main impacts, as well as the difficulties and challenges that arise in the plan of social intervention. The data supporting this analysis were collected through 18 semi-directive interviews with Roma students enrolled in secondary education and interviews with technicians and coordinators of 5 Escolhas projects located in the Metropolitan Area of Lisbon,
\end{abstract}

Keywords: Escolhas projects, Roma; perceptions; school trajectories. 


\section{Introdução}

Este texto ${ }^{1}$ tem por base uma análise exploratória de índole qualitativa e que se realizou no âmbito do projeto EDUCIG - Desempenhos escolares entre os Ciganos: Investigação-Ação de projeto de Co-Design (CIES-Iscte), durante o ano de 2019 e $2020^{2}$, que está a ser desenvolvido no quadro do Cies-Iscte e é financiado pela Fundação para a Ciência e Tecnologia. Neste contexto de análise pretende-se estabelecer uma espécie de confronto analítico entre as perceções dos técnicos/coordenadores de alguns projetos do programa Escolhas sediados na Área Metropolitana de Lisboa (AML) e as perceções destes estudantes, no que concerne sobretudo aos fatores-chave para a continuidade dos percursos escolares. Além desta dimensão, a análise focalizar-se-á ainda nos impactos dos projetos e nas dificuldades e desafios que se colocam à intervenção.

Antes da realização das entrevistas aos técnicos e coordenadores dos projetos Escolhas, foi feito um levantamento de todos os projetos do Programa Escolhas sediados nas áreas metropolitanas de Lisboa e do Porto e foram estabelecidos contatos diretos com o intuito de aferir quais os que efetivamente intervinham junto de pessoas e famílias ciganas.

O Programa Escolhas é um programa que se inscreve na esfera da ação do Alto Comissariado para as Migrações (ACM) e teve início em 2001, vocacionado para a promoção da inclusão social de crianças e jovens oriundas de contextos socioeconómicos mais vulneráveis, contando, na atual geração do programa, com 104 projetos distribuídos pelo território nacional. Os seus objetivos são promover o sucesso escolar, formação profissional, o desenvolvimento de competências pessoais e sociais e traçar e acompanhar projetos de vida de jovens socialmente excluídos, apostando nas suas capacidades. O seu público alvo é composto por crianças e jovens entre os 6 e os 25 anos de idade, sendo que cada projeto pode definir um intervalo menor de idades.

$\mathrm{Na}$ atualidade o programa encontra-se já na sua $7^{\mathrm{a}}$ geração, registando 104 projetos, 36 estão localizados na Área Metropolitana de Lisboa (AML), sendo que 24 afirmaram, no momento da candidatura, estarem inseridos num território com população cigana. No entanto, nem todos acabaram por ter entre os inscritos jovens e famílias de etnia cigana e os projetos identificados com participantes de etnia cigana contam maioritariamente com a participação de crianças que frequentam o ensino primário ou básico. Foram entrevistados 6 coordenadores e 1 técnico de 5

\footnotetext{
${ }^{1}$ Agradecemos os comentários e contributos pertinentes da Professora Doutora Olga Magano e da Doutora Susana Batista, que foram incorporados na redação deste texto ainda de caráter exploratório.

${ }^{2}$ Este projeto está a ser desenvolvido no quadro do CIES-Iscte, e é financiado pela Fundação para a Ciência e Tecnologia.
} 
projetos diferentes, sendo que 4 projetos se localizam no concelho de Lisboa, 1 na Amadora e 1 em Cascais.

As entrevistas realizadas, de caráter semi-estruturado, procuraram conhecer a perspetiva dos interventores sociais no que concerne aos contextos vivenciais de algumas crianças e jovens ciganos, apreender os seus trajetos de vida, aspirações e experiências escolares e compreender os modos de funcionamento, atividades e impactos dos projetos Escolhas junto das crianças, jovens e respetivas famílias.

Além das entrevistas aos coordenadores e técnicos dos projetos Escolhas da AML, foram realizadas 18 entrevistas a alunos ciganos da AML. O guião destas últimas entrevistas é mais extenso e compreende um leque maior de questões, pelo que serão selecionadas apenas as dimensões de análise mais focadas nas perceções sobre os fatores se continuidade dos percursos escolares. Desta forma, o objetivo do presente artigo passa por confrontar as perceções sobre experiências e situações descritas pelos técnicos e coordenadores dos projetos com as visões dos jovens ciganos com um percurso de continuidade escolar (ao nível do ensino secundário).

\section{Contexto teórico e empírico de partida}

De acordo com Magano e Mendes (2016), atualmente o cumprimento do $1^{\text {o }}$ ciclo é um fenómeno generalizado entre as pessoas ciganas das áreas metropolitanas de Lisboa e do Porto e existe um aumento da frequência em creches, jardins de infância e centros de apoio ao estudo. Os problemas passaram a residir sobretudo nas transições de ciclo, marcadas pelo insucesso, falta de aquisição das competências necessárias e na perceção generalizada de que a escolaridade obrigatória não é uma prioridade (Abrantes, 2008). Atendendo aos dados da Direção-Geral de Estatísticas da Educação e Ciência, para o ano letivo 2016/2017 (DGEEC, 2018), verifica-se que a percentagem de abandono dos alunos ciganos matriculados em escolas do ensino público no $1^{\circ}$ ciclo é residual $(2,2 \%)$, mas aumenta consideravelmente no ciclo seguinte (para 11,3\%), sendo na área metropolitana de Lisboa que os níveis de abandono são os mais elevados do país (atingindo os 29\% no Ensino Secundário). No final do Ensino Básico (3º ciclo), a maioria dos alunos ciganos matriculados nas escolas do país tem pelo menos uma retenção (58\%), peso que desce para perto de um terço no ciclo seguinte, o que indica que muitos abandonaram nessa transição. Os níveis de insucesso mais elevados registam-se na AML (75\% dos alunos ciganos têm pelo menos uma retenção no $3^{\circ}$ ciclo e $53 \%$ no ensino secundário), seguido do Norte (59\% no $3^{\circ}$ ciclo e $46 \%$ no ensino secundário). A escolaridade obrigatória por lei, fixada no final do ensino secundário ( $12^{\circ}$ ano) ou até ao décimo oitavo aniversário, é ainda uma reali- 
dade longínqua para muitos dos jovens ciganos, sobretudo entre aqueles que percecionam a escola como um local para crianças e adolescentes, não para jovens adultos ou adultos (Magano \& Mendes, 2016). Em idades mais avançadas e em contexto europeu, a percentagem de ciganos a abandonar a escola entre os 18 e os 24 anos varia entre $72 \%$ na República Checa e $93 \%$ na Roménia, França, Espanha, Portugal e Grécia. A maioria abandona a escola antes de conseguir um grau secundário. Na verdade, os baixos níveis de escolaridade têm um impacto na obtenção de emprego, sendo que o desemprego é 3 vezes maior entre os ciganos, ainda que $74 \%$ dos desempregados ciganos afirmem que estão à procura de trabalho (García-Carrión, Molina-Luque, Roldán \& 2017).

De facto, a pobreza, estruturas familiares e as condições de vida que marcam os modos de vida de muitas famílias são os antecedentes principais das situações de risco escolar. Mas a escola, a sociedade local onde se insere a família e a escola, os fatores individuais/pessoais também são relevantes (Mendes, Magano \& Costa, 2020). A transição do ensino básico para o secundário é por vezes identificado como um período conturbado, de ansiedade e falta de motivação. O background dos estudantes tem um grande impacto. Desemprego, rendimentos baixos e pouca escolaridade das famílias estão associados ao risco de abandono escolar, bem como a falta de participação e o apoio dos pais, as retenções e notas baixas e o contexto socioeconómico da população escolar. Acresce que os percursos escolhidos antes e durante o secundário têm também um impacto importante na inclusão/exclusão escolar (García-Carrión, Molina-Luque \& Roldán, 2017).

\section{Aproximação aos contextos de intervenção}

Em relação aos territórios onde os projetos estão inseridos, a maioria são compostos por bairros sociais, caraterizados pela falta de serviços e equipamentos de proximidade (segurança social, escolas, juntas de freguesia, serviços de saúde), equipamentos de comércio, lazer e espaços verdes, registando problemas de sobrelotação, precariedade, falta de exemplos de sucesso, desemprego, baixa escolarização (com situações de analfabetismo e iliteracia digital) e taxas significativas de desocupação e estratégias sobrevivência baseada na economia paralela. Acresce ao descrito, que estes territórios são alvo de uma estigmatização que condiciona ainda mais as relações com o exterior. Mas a estes territórios são também imputados atributos positivos: a interajuda, o espírito bairrista enquanto gerador de dinâmicas sociais, a confiança e a amizade.

O aprisionamento, a segregação territorial e a estigmatização são fenómenos que marcam estes territórios de intervenção. 
Estão aqui neste bairro, neste contexto que os aprisiona um bocado, é um ambiente castrador e regulador - a cultura de bairro, a falta de casos de sucesso...

(Técnica, Amadora)

Em 2018 levámos pela primeira vez jovens de 12,13 anos à praia. Não sabiam que a água era salgada. Têm tudo aqui [Bairro Padre Cruz, Carnide] dentro, nascem aqui, não precisam de sair do bairro para nada. O máximo que iam, o passeio mais espetacular era ao centro comercial Colombo, que é aqui atrás.

(Coordenadora, Lisboa)

Na Torre há uma mudança de paradigma clara. Desde que foi feito o festival vão pessoas de máquina a fotografar as empenas. Mas quando vais falar com as pessoas, a maior parte delas são estrangeiras. Isso foi uma mudança brutal, mas é raro o cascalense que vai ao bairro da Torre e fica na boa a tirar fotos. É mesmo uma questão de estigma.

(Coordenador, Cascais)

Todos os projetos Escolhas entrevistados são largamente conhecidos e legitimados nos territórios onde estão inseridos e têm uma procura e adesão significativa por parte dos jovens e das suas famílias. O número de inscritos difere de projeto para projeto, sendo que o projeto que mais inscritos tinha no final da geração anterior rondava os 400 inscritos. $^{3}$

Em relação aos inscritos de origem cigana, os valores também variam, mas é consensual a opinião de que há uma maior participação de rapazes, sobretudo de crianças. Importa salientar que os jovens ciganos deixam de frequentar os espaços mais cedo que os restantes jovens, principalmente as raparigas, em virtude da assunção de tarefas familiares e do maior controlo social a que estão sujeitas. Excetuando um dos projetos (localizado em Cascais), cujo público alvo são sobretudo os adolescentes e jovens adultos, os projetos revelaram uma falta de interesse por parte dos adolescentes e uma maior facilidade em cativar as crianças, ciganas. Os inscritos de origem cigana foram caraterizados pelos coordenadores e técnicos dos projetos como uma certa desfiliação face à escola, registando-se uma elevada inserção nos Cursos de Educação e Formação (EFAs) e no Programa Integrado de Educação e Formação (PIEFs), assim como, elevadas taxas de absentismo e insucesso escolar, detendo projetos de vida não estruturados e registando-se a ausência falta de casos de sucesso.

\footnotetext{
${ }^{3}$ Para a realização de qualquer atividade no contexto do projeto é necessária uma inscrição por pessoa. O número de inscritos contabiliza todas as pessoas que realizaram inscrição, o que não significa que frequentem os projetos com uma periodicidade regular.
} 
Uma das entrevistadas afirma o seguinte:

Chegam ao $5^{\circ}$, muitos não sabem ler nem escrever, deparam-se com muitas disciplinas, uma carga horária excessiva, muitos professores, trabalhos de casa. Os pais também não insistem, porque para eles o abandono também foi precoce, se alguma vez tiveram na escola.

(Técnica, Projeto na Amadora)

\section{Fatores motivadores para a continuidade escolar}

As respostas dos técnicos dos projetos Escolhas apontam como fatores motivadores para a permanência e continuidade dos percursos escolares, as relações interpessoais de amizade, a afirmação identitária, o desejo de um futuro melhor e por fim, a função lúdica e libertadora da escola.

Eles gostam. Da parte lúdica da escola. Eles não estão habituados é a estar sentados, às regras. Mas eles gostam. A escola até é algo libertador para eles. Porque na escola podem ter comportamentos que não podem ter no bairro. Falam com toda a gente (...), a escola até acaba por ser algo libertador para eles.

(Coordenadora, Amadora)

Alguns dos entrevistados revelam representações estereotipadas sobre as pessoas ciganas no que se refere à relação com a instituição escolar, evidenciando o desinteresse e a desresponsabilização parental.

Sim. A grande maioria está inscrita na escola, mas isso vale o que vale. Há muito absentismo, não há uma valorização por parte das famílias, não há acompanhamento e responsabilização parental.

(Coordenadora, Lisboa)

Para os alunos, ainda de acordo com a perspetiva dos técnicos, a escola é vista como uma perda de tempo e um risco de serem catalogados como brancos ou senhores (não ciganos) por terceiros. Os próprios técnicos apontam as dificuldades e a pressão a que são sujeitos os que têm trajetórias escolares mais prolongadas.

(...) "Estão sempre a gozar comigo, ah tens mania que és doutor, que és mais esperto que a gente". Faziam-lhe bullying por estar a estudar. Como se fossem valores contraditórios. Que não têm que ser. Eu acho que o medo é esse, a partir do momento em que tens mais educação achares que a cultura que te trouxe até aqui é de ser perdida, quando não, até deve ser valorizada.

(Coordenador, Cascais) 
Mas a dualidade integração/assimilação também é aflorada por uma das entrevistadas: Nós dizemos que eles não se integram. Quando digo nós, digo a sociedade, a maioria. Eles não se integram, mas também este querer que eles se integrem é um pedido inconsciente da nossa parte que eles se aculturem, que percam a cultura deles.

(Coordenadora, Lisboa)

Estas perceções estão, em parte, em consonância com algumas das manifestadas pelos jovens ciganos. Antes de mais, importa clarificar que existe uma diferenciação entre o contexto de intervenção destes técnicos, que de uma forma geral lidam, principalmente com casos de abandono e insucesso escolar e a situação escolar dos jovens entrevistados. Em contraposição, os entrevistados ilustram casos de continuidade escolar, na medida em que evidenciam um percurso escolar ao nível do ensino secundário. Para os alunos entrevistados, a escolaridade é percecionada como indispensável para assegurar um emprego, um futuro estável e para a construção de um modo de vida onde conseguem ser autónomos e emancipados em termos pessoais e socioeconómicos. Estas perceções surgem muitas vezes acopladas à ideia de que as ocupações tradicionalmente desempenhadas pelas famílias ciganas estão em declínio e já não garantem na atualidade as condições mínimas para uma vida estável, sendo necessária uma maior incorporação na sociedade maioritária. Assim, estes jovens com percursos de continuidade escolar apresentam certos traços individuais já evidenciados em estudos anteriores, tais como o esforço, tenacidade, compromisso pessoal e confiança (Abajo e Carrasco, 2004), capacidade de resiliência e competências de relacionamento interpessoal (Bereményi e Carrasco, 2017) vontade de estudar, gosto pela escola e responsabilidade em não faltar a compromissos escolares (Magano e Mendes, 2016).

Segundo os jovens entrevistados, as atitudes dos seus pais face à instituição escolar deixam transparecer uma valorização generalizada (apenas dois jovens afirmaram não ter apoio familiar em relação ao percurso escolar) da escolarização, quer devido ao facto de a escola ser encarada como geradora de oportunidades que as gerações mais velhas não tiveram oportunidade de alcançar, quer pela em virtude da componente integradora da escola que tem desmistificado certos preconceitos face à cultura cigana. A valorização da escola manifesta-se no apoio prestado por parte dos pais, esforços envidados para manter os filhos na escola perante pressões exercidas intra grupo cigano. Diversos jovens referem que os pais foram intransigentes em relação à assiduidade, comportamento ou resultados escolares, estabelecendo metas mínimas de anos de escolaridade a alcançar, geralmente a finalização do ensino secundário. 


\section{Quais as barreiras à continuidade escolar?}

Segundo os técnicos e coordenadores dos projetos Escolhas, os principais fatores que justificam o abandono e insucesso escolar prendem-se com o desconhecimento da comunidade escolar em relação à cultura, tradições, condições e estilos de vida das pessoas ciganas, à falta de interesse e implicação dos professores face ao desempenho dos alunos ciganos, existência de turmas que segregam alunos de ciganos, falta de interesse por parte de alunos em alguns conteúdos lecionados, dificuldades por parte dos alunos ciganos em cumprir horários e tarefas e em permanecerem focados durante algum tempo, falta de casos de sucesso e de modelos de referência, indefinição de objetivos de vida em idade precoce (em que a escola deixa de ser vista como uma mais-valia), e, por último, a dualidade entre ir passando de ano sem apreender as competências mínimas ou ficar retido em turmas com colegas cada vez mais novos. Na perspetiva de uma das técnicas entrevistadas as causas residem na instituição escolar e nos seus profissionais.

"A comunidade escolar também não está muito envolvida, ou não sabe muito bem o que é a cultura cigana. Não está muito interessada em saber gerir ou incluí-los. Muitas vezes a escola não os inclui. Os professores não os incluem. E eles sentem isso. Verbalizam muito isso. Que se sentiram discriminados."

(Técnica, Amadora)

No que diz respeito às barreiras à continuidade escolar, os técnicos e coordenadores entrevistados demonstram um conhecimento mais aprofundado, o que os coloca numa posição de uma maior aproximação face às perceções dos jovens ciganos com perfis de continuidade escolar. Nos discursos dos entrevistados, ficam patentes como principais fatores limitadores da continuidade escolar: as razões culturais, associadas ao "hábito" ou ligadas à educação fornecida pelos pais, o que remete para um estilo de vida "tradicional" e "antiquado" em que a escola não constitui uma necessidade para a "vida cigana" tradicional, caraterizada pela constituição precoce da família e pelo trabalho familiar "nas vendas". Outros jovens, por sua vez, apresentam uma ideia semelhante, mas culpabilizam na íntegra os próprios alunos ciganos, acusando-os de falta de objetivos e de deterem uma ideia preconcebida e tradicionalista sobre o seu projeto de vida e que passa maioritariamente por casar cedo, ter filhos e ser vendedor. Há alguns jovens que falam de casos em que são os próprios pais que não permitem, não encorajam os filhos a estudar ou simplesmente não mostrarem interesse no percurso escolar do filho. Houve, entre os entrevistados, quem referisse o impacto negativo das condições de habitação em contexto de bairro social, afirmando que esta condição funciona como condicionadora de oportunidades. De facto, as pessoas ciganas que vivem em condições de pobreza, exclusão social são mais identificáveis (Magano, 2007) e expostas a situações discriminatórias, sobretudo 
quando habitam em contexto de bairro social com outras famílias ciganas, onde acabam por ser detetadas pelos técnicos dos projetos de ação social locais e/ou poder local. Os ciganos integrados na sociedade portuguesa, isto é, que não residem em contexto de habitação social, acampamentos ou em bairros autorreproduzidos e, que geralmente, exercem um trabalho por conta de outrem e com rendimento fixos, são muitas vezes socialmente invisíveis. A falta de aproveitamento escolar e, em particular, as reprovações foram também apontadas pelos alunos como um fator que condiciona a continuidade dos percursos escolares, a partir do momento em que os jovens, ao reprovarem sistematicamente, acabam por ficar desfasados em termos etários face à faixa etária da sua turma, o que faz com que deixe de haver entre eles um sentimento de identificação com a escola e, em alguns casos, sintam vergonha em frequentar a escola em turmas em que os colegas têm um desnível etário significativo face ao próprio.

A situação financeira das famílias foi também um fator destacado, bem como a necessidade de começar a trabalhar cedo para alcançar a independência económica e sustentar a família de origem ou, em alguns casos, a família constituída, à semelhança do que foi também salientado por Magano (2010), em que os jovens ciganos começam a trabalhar cedo, seja a ajudar nas "vendas" seja nos trabalho doméstico e cuidados dos irmãos mais novos, no caso das raparigas (Mendes, 1997 e 2007).

Outra causa para o abandono escolar precoce está associada ao estilo de vida mais "tradicional", mas sobretudo a vontade que muitos demonstram de constituição precoce da própria família através do casamento cigano. O casamento é visto pelos restantes membros da comunidade como uma transição simbólica entre a juventude (jovem solteiro) para a adultez (casado), e, por isso, valoriza-se a sua passagem rápida, uma vez que está associada a uma questão de status em contexto intra étnico (Mendes, 1997 e 2007).

Alguns jovens referiram também uma quota-parte de responsabilidade da instituição escolar, acusada de racismo, discriminação e falta de expetativas dos professores quanto aos alunos ciganos, questões largamente dissecadas pelos entrevistados.

"Sei lá, eu acho que, por vezes, nas escolas, os professores já estão tão habituados ao que os alunos ciganos fizeram, que já não acreditam que possa haver mudança. Por exemplo, há cinco anos para cá, os... os alunos ciganos não... não tinham nenhum interesse na escola, eles nem praticamente levavam o material, iam para as aulas, estavam ali, mas nada mais que isso. Então, os professores, acho que ficaram com essa ideia. Mas tem vindo, hoje, na sociedade de hoje, tem vindo uma geração de jovens ciganos que querem vir a aprender e a estudar e a ter um futuro. E era bom que acreditassem mais em nós." (sexo feminino, 16 anos, Amadora) 


\section{Impactos dos projetos, dificuldades e desafios}

No que toca aos impactos dos projetos, os técnicos e coordenadores salientam o estabelecimento de relações de confiança e amizade entre os diversos inscritos e entre os inscritos e técnicos; o aumento das competências pessoais, sociais, digitais; uma maior valorização da importância da escola como geradora de oportunidades na construção de um futuro estável e a transformação de zonas estigmatizadas dos bairros através da promoção de imagens positivas do território e do estabelecimento de contactos com o exterior dos bairros. Alguns entrevistados realçam ainda o incremento dos níveis de escolarização dos jovens.

Quisemos muito criar esta lógica de interligação entre territórios, interligação entre boas práticas. Temos atividades comuns, saídas são comuns, alugamos autocarros para levar os dois territórios. E se isto ao início foi um bocadinho desafiante hoje já não. Agora os jovens já pensam em dinâmicas com os outros jovens. Existe claramente uma ponte entre os dois bairros. (Coordenador, Cascais)

Houve aqui um ATL há muitos anos, desde então, é uma zona completamente estigmatizada do bairro. As pessoas tinham muito medo de a frequentar. Só a nossa presença promove uma imagem positiva do bairro. $O$ sítio onde nós treinamos (futebol de rua) é uma zona que também está transformada. Há dez anos atrás ninguém passava lá, ou quem passava não era para as melhores práticas.

(Coordenadora, Lisboa)

Embora na região de Lisboa e Vale do Tejo o associativismo seja maior (Calado et al., 2019), entre os jovens entrevistados na AML apenas 4 estão inscritos em projetos de ação social ou em associações, e nenhum dos jovens frequenta os projetos Escolhas referidos. As suas participações oscilam entre a participação nos eventos e atividades organizadas pelos projetos e pelo apoio prestado na organização das mesmas. Os próprios jovens afirmam que os projetos de ação social e as associações, sobretudo as ciganas, têm um impacto positivo no incremento da escolaridade das pessoas ciganas. As associações e projetos de intervenção social permitem aos jovens alargar os seus círculos sociais, tomar conhecimento e obter privilégios (como é o caso da obtenção das bolsas Roma Educa do Alto Comissariado para as Migrações, criadas para apoiar jovens ciganos no ensino secundário, das quais alguns entrevistados são beneficiários), terem um acompanhamento personalizado e contínuo no seu percurso escolar e ocuparem os seus tempos livres com atividades dinâmicas, acompanhados por outros jovens.

Em relação aos desafios e dificuldades vivenciadas pelos coordenadores e técnicos dos projetos Escolhas, foram identificadas as dificuldades mais ligadas à gestão e funcionamento do 
programa, sobretudo no que toca às novas inscrições em cada geração do programa e às avaliações, a dificuldade em gerir os fundos limitados e em criar um plano estratégico de ação sustentável, a imprevisibilidade quanto à continuidade dos projetos na transição de geração Escolhas, o que também incapacita os técnicos e coordenadores de planearem ações a longo prazo. Em relação à escolaridade dos alunos ciganos foi identificado o desafio transversal de contornar a desmotivação, tornar a escola uma prioridade e difundir a perceção de que a escola pode ser uma mais-valia na vida destes jovens, um meio de atingir objetivos, estruturar a sua vida.

É algo que realmente tentamos entender, o que é que motiva estes jovens a ir à escola, e nós não conseguimos chegar a essa conclusão.

(Coordenadora, Lisboa)

Estás a trabalhar com desocupados, portanto são jovens naturalmente desmotivados. São jovens que se não estão desmotivados estão já numa economia paralela ou estão a ter comportamentos desviantes que lhes permitem ter aqui assim algum rendimento. Até que ponto é que consegues ter uma oferta apelativa para estes jovens que desistiram da escola? Como é que lhes consegues mostrar alguma coisa em que eles são bons, que eles gostam de fazer e de onde consigam tirar rendimento suficiente para conseguirem sobreviver? Isso é o maior desafio.

(Coordenador, Cascais)

\section{Notas conclusivas}

As desigualdades histórico-estruturais determinam em grande medida os contornos já traçados relativamente à situação e presença dos ciganos na escola pública em Portugal. Apesar das mudanças sociais que têm marcado e reconfigurado a relação entre ciganos e a escola, sendo de evidenciar entre outras mudanças o maior acompanhamento e implicação das famílias ciganas no processo de escolarização das crianças e jovens (Mendes, Magano, \& Costa, 2020) e pese embora o compromisso assumido pelo Estado português com a implementação da Estratégia Nacional de Integração das Comunidades Ciganas (ACM, 2013), a taxa de execução das medidas ligadas ao eixo educação continua a ser muito baixa, apenas 10,7\% entre 2013-2016. Mas em particular, no que se refere às trajetórias escolares dos alunos ciganos ao nível do ensino secundário, há ainda um longo caminho a percorrer, pois, a taxa de matriculados no ensino secundário não atinge sequer os 3\%. (contra 79,3\% dos portugueses em geral). A convergência de resultados entre estudantes ciganos e não ciganos é algo que ainda está longe de acontecer, mas tal tem que ser feito através de uma estratégia multinível e colaborativa entre stakeholders e os próprios ciganos, famílias e seus representantes. 


\section{Bibliografia}

Abajo, J. E. \& Carrasco, S. (Eds.) (2004), Experiencias y trayectorias de éxito escolar de gitanas y gitanos en espana. Encrucijadas sobre educación, género y cambio cultural, Madrid CIDE, Instituto de la Mujer.

Abrantes, P.; Seabra, T.; Caeiro, T.; Almeida, S.; \& Costa, R. (2016). “A escola dos ciganos”: contributos para a compreensão do insucesso e da segregação escolar a partir de um estudo de caso. Configurações, 18, 47-66.

Bereményi, B. (2018). Costes de la movilidad entre gitanas y gitanos com trayectorias académicas de éxito. Em Andrés, R.; \& Masó, J. (eds.) (Re)visiones. Políticas, (auto)representaciones y activismos en diálogo com el género y la sexualidade (138-171). Barcelona: Edicions

Bereményi, B. Á. \& Carrasco, S. (2017). Bittersweet Success. The Impact of Academic Achievement Among the Spanish Roma After a Decade of Roma Inclusion. In Pink \& Noblit (Eds.) Second International Handbook of Urban Education. New York: Springer International Handbooks of Education.

Calado, P., Moreira, L.J., Costa, S., Simões, C. \& Matos, M. G. (2019). "The Roma Population in Portugal: A Changing Picture", Óhidy, A. \& Forray, K.R. (Ed.) Lifelong Learning and the Roma Minority in Western and Southern Europe. Bingley: Emerald Publishing Limited. 117-137.

DGEEC (2018). Perfil escolar da comunidade cigana 2016/17. Lisboa: DGEEC.

Gamella, J. (2011). Historias de éxito. Modelos para reducir el abandono escolar de la adolescencia gitana. Secretaría General Técnica. Ministério de Education.

García-Carrión, R.; Molina-Luque, F., \& Roldán S. M. (2018). How do vulnerable youth complete secondary education? The key role of families and the community, Journal of Youth Studies, 21:5, 701-716.

Gofka, P. (2017). Promoting Social Justice and Enhancing Educational Success: Suggestions from Twenty Educationally Successful Roma in Greece, Urban Review 49, 443-462

Magano, O. (2010). Tracejar vidas normais: estudo qualitativo sobre a integração social de indivíduos de origem cigana na sociedade portuguesa. Tese de doutoramento em Sociologia. Lisboa: Universidade Aberta.

Magano, O. (2012). Pluralidade e reconfiguração da identidade cigana em Portugal. Sociologia, Revista da Faculdade de Letras da Universidade do Porto, XXIII, 251-268.

Magano, O. \& Mendes, M. M. (2016). Constrangimentos e oportunidades para a continuidade e sucesso das pessoas ciganas. Configurações, 18, 8-26.

Magano, O. \& Mendes, M. M. (2014). Ciganos e políticas sociais em Portugal, Sociologia, Revista da Faculdade de Letras da Universidade do Porto, Número temático - Ciganos na Península Ibérica e Brasil: estudos e políticas sociais, 15-35.

Mendes, M. M. (1997). Etnicidade, Grupos Étnicos e Relações Multiculturais. Elementos para a compreensão das relações entre ciganos e não ciganos, no âmbito de uma 
Sociologia das Relações Étnicas e Rácicas. Dissertação de Mestrado em Sociologia, Faculdade de Letras da Universidade do Porto.

Mendes, M. M. (2007). Representações face à discriminação: ciganos e imigrantes russos e ucranianos na área metropolitana de Lisboa. Tese de Doutoramento em Ciências Sociais, Lisboa: Instituto de Ciências Sociais da Universidade de Lisboa.

Mendes, M. M.; Magano, O., \& Candeias, P. (2014). Estudo Nacional sobre as Comunidades Ciganas. Estudos OBCIG, 1, Lisboa: Alto Comissariado para as Migrações.

Mendes, M. M.; Magano, O. \& Costa, A. R. (2020). Ciganos Portugueses. Escola e mudança social. Sociologia, Problemas e Práticas, 93, 109-126. 



\section{PARTE III \\ CONTEXTOS, ATIVISMO CIGANO E MOBILIZAÇÕES DE EMANCIPAÇÃO}





\title{
Capítulo 8. \\ Ciganos/as no Brasil: \\ ações, mobilizações e ativismo político
}

\author{
JAMILLY RODRIGUES DA CUNHA ${ }^{1}$ \\ Doutora em Antropologia, pesquisadora do Núcleo de Estudos em Etnicidade; Universidade Federal de Pernam- \\ buco e professora de educação básica \\ jamillycunhaantropologia@gmail.com
}

Resumo: O presente artigo visa discutir o cenário de mobilização política a partir do ativismo de algumas mulheres Ciganas ou, respeitando sua forma de auto reconhecimento, mulheres Romani no Brasil. Tais ativistas têm procurado atuar para além dos limites domésticos, participando das discussões e construções de políticas públicas, buscando descontruir um imaginário que pouco diz sobre suas reais formas de vida. A pesquisa que embasa tais reflexões foi realizada durante o doutoramento em Antropologia, período no qual acompanhei, a partir do método de observação participante, algumas mulheres Calon e Kalderash. Foi a partir de tal exercício que compreendi suas dinâmicas de vida e um ativismo que também demandava mais valorização e acesso aos direitos que cotidianamente ainda lhes são negados, além disso, uma discussão de gênero dava seus primeiros, mas, sólidos passos no combate à opressão e na busca pelo empoderamento feminino.

Palavras-chave: Ativismo político; Mulheres; Identidade

\begin{abstract}
This article aims to discuss the scenario of political mobilization based on the activism of some Roma women or, respecting their form of self-recognition, Romani women in Brazil. Such activists have sought to act beyond domestic limits, participating in the discussions and construction of public policies, seeking to deconstruct an imaginary that says little about their real ways of life. The research that underlies these reflections was carried out during the

\footnotetext{
${ }^{1}$ Jamilly Rodrigues Cunha é doutora em Antropologia pela Universidade Federal de Pernambuco, Brasil. É pesquisadora do Núcleo de Estudos em Etnicidade, Universidade Federal de Pernambuco e professora de educação básica. É mestre em Antropologia pela Universidade Federal de Pernambuco (PPGA-UFPE). Bacharel em Ciências Sociais com área de concentração em Antropologia pela Universidade Federal de Campina Grande (UFCG). Licenciada em Ciências Sociais pela Universidade Federal de Campina Grande (UFCG) Membro dos seguintes grupos: Núcleo de Estudos e Pesquisas sobre Etnicidade - NEPE/UFPE; Grupo de Estudos Culturais- GEC/UFPB; Laboratório de Estudos em Movimentos Étnicos- LEME/UFCG. Editora da Revista de Estudos e Investigações Antropológicas-REIA.
} 
Ph.D. in Anthropology, a period in which I followed, using the method of participant observation, some women Calon and Kalderash. It was from such an exercise that I understood their dynamics of life and an activism that also demanded more appreciation and access to rights that are still denied them daily, in addition, a gender discussion gave its first, but solid steps in the fight against oppression and in the search for female empowerment.

Keywords: Political activism; Women; Identity.

"Cigano", "Rom", "Romani”, "Calon” ou "Sinti”, entre outras designações, são as formas de autorreconhecimento e como são identificados estes grupos étnicos que vivem em solo brasileiro desde o século XVI. Historicamente colocados à margem ou vítimas de perseguição, preconceito e discriminação, atualmente, tais indivíduos têm desafiado o Estado no processo de negociação e construção de políticas públicas a partir de demandas específicas e que estão relacionadas as suas formas e estratégias de sobrevivência. Nesse sentido, esse artigo foi produzido utilizando os dados da minha pesquisa de doutorado ${ }^{2}$ em Antropologia e, irá abordar, sobretudo, o ativismo político desenvolvido pelos agentes ciganos/as.

Pensando acerca de dados demográficos, permanece certo desconhecimento acerca dos ciganos/as no Brasil. Alguns órgãos oficiais do governo ${ }^{3}$ estima a existência de um milhão de pessoas identificadas como ciganas vivendo nas cinco regiões brasileiras, contudo, consideramos que esse é um dado pouco preciso e que pode estar distante da realidade. Há alguns mapeamentos que têm sido realizados pelas próprias lideranças e ativistas ciganos/as, como o que fora produzido por Costa et al. (2017) a partir da revisão e atualização da Base de dados do Tabulador de Informações do Cadastro Único (CadÚnico) da Secretaria de Avaliação e Gestão da Informação do Ministério do Desenvolvimento Social (SAGI/MDS) que aponta a existência de 1.148 acampamentos declarados, acampamentos provisórios/transitórios, ranchos e barracas isoladas existentes em 849 municípios do país.

Importante enfatizarmos a diversidade na forma que se organizam espacialmente, socialmente e como se relacionam com uma "identidade cigana", uma identidade que é cotidianamente construída a partir do reconhecimento da diferença nos processos fronteiriços, como bem já destacou autores que estudam este fenômeno (Hall, 2011; Silva; 2011). Por isso ser comum

\footnotetext{
${ }^{2} \mathrm{O}$ trabalho final recebeu por título "Somos mulheres, somos fortes e temos princípios": ativismo político a partir da atuação de mulheres "Calin e Romani" e seus projetos de construção identitária e foi defendido em fevereiro de 2020 .

${ }^{3}$ Dado indicado no Guia de Políticas Públicas para Povos Ciganos produzida pela Secretária de Políticas de Promoção da Igualdade Racial - SEPPIR em 2013.
} 
encontrarmos formas tão distintas de como se relacionam com a identidade, que aparece ora de forma menos vinculada em seu cotidiano, ora é estrategicamente enunciada em um contexto de negociação política.

No Brasil é recente a ocupação de lideranças e ativistas ciganos/as em espaços públicos de poder, consequentemente, esse é um tema pouco abordado e quando olhamos para a Antropologia política produzida em nosso país, os estudos têm sido realizados, sobretudo, a partir da atuação e mobilização de outras minorias étnicas. Oliveira (2010: 63) ao discutir acerca de um ativismo indígena, aponta para a década de 1970 como momento importante para a criação desta forma de articulação, tendo em vista a "conjuntura de um governo militar que tencionava a integração, o quanto antes, das comunidades indígenas à sociedade nacional”. No entanto, limitar um período para uma articulação de representantes de comunidades ciganas no Brasil não é tarefa simples, haja vista que a maioria destes tais atores sociais permaneceram durante muito tempo a parte de mobilizações e discussões políticas sobre seus direitos étnicos, bem como dos próprios desdobramentos da Constituição Federal de 1988.

Quando se olha para o cenário internacional, essas representações não são recentes e gozam de uma articulação que datam início do século XX. Conforme indicado pela pesquisadora Sousa (2012: 07), a bandeira cigana, por exemplo, foi elaborada em um encontro na década de 1930, reformulada e reapresentada no "First World Romani Congress" em 1971, congresso pensado no sentido de promover a realização de fóruns e debates sobre a população Rom da Europa com a participação de representações ciganas. Além disso, segundo Frans Moonen (2011: 169) há em toda a Europa, sobretudo, após a década de 1950 o surgimento de muitas organizações ciganas que, com formas de articulação bastante distintas, têm buscado acessar melhoria de condições de vida seja para sua família, seja para toda uma coletividade.

Sabe-se que na Europa, a partir da segunda metade do século XX, houve articulação de vários representantes ciganos que buscaram apoio no sentido de promover uma integração ${ }^{4}$ com a sociedade não-cigana, sobretudo, na garantia de direitos cidadãos negados pelos Estados que não reconhecem a sua nacionalidade. Guimarais (2012: 100) afirma que após o fim do regime comunista, tendo foco maior à população cigana, algumas ONGs surgiram na Europa Central e Oriental, visando promover os direitos humanos e a igualdade étnica e de gênero.

No Brasil, poucos são os dados que apontam para uma ação mais efetiva de participação cigana em movimentos sociais ou até nos processos históricos como o regime militar e a luta

\footnotetext{
${ }^{4}$ Uma integração social entendida como "la posicion interdependente em el interior del sistema social, que otorga la adquisicion jurídica y practica de los derechos cívicos” (Roman, 2010: 36).
} 
pela democratização no Brasil. Afinal, onde estavam os/as ciganos/as nestes períodos de efervescente participação popular? Coutinho (2014: 04) revela que no projeto de uma dita "construção civilizatória", a polícia agia com repressão contra a "classe perigosa", neste grupo, "contraventores", "quiromantes e cartomantes" foram identificados como aqueles que apresentavam "ilícitos meios de vida" e como uma consequência deveriam sofrer a repressão e o afastamento do restante da sociedade. A autora fala também de alguns registros que negam a entrada de ciganos/as no país, como ocorreu em 1938 a partir de um decreto que tratava acerca da chegada de estrangeiros no país, ou mais precisamente, os "indigentes, vagabundos, ciganos e congêneres $[\ldots] "$.

Esse é o tipo de análise que aparece nas bibliografias quando pensamos o tema. Não se tem a visão dos/as ciganos/as ou suas formas de ação. Não conhecemos como reagiram a estes contextos de perseguição e repressão. Em campo, certa vez ouvi uma frase bastante significativa que me ajudou a refletir tais aspectos. Ao perguntar sobre a época nômade e o contato com outros grupos sociais, quis provocar uma cigana da cidade de Sousa ${ }^{5}$ sobre a relação de seu grupo com os "bandos" de cangaço ${ }^{6}$, tendo em vista a força deste movimento social no Nordeste e a frequente associação entre eles ${ }^{7}$. Foi aí que a mesma respondeu: "Cangaço? Cangaceiro somos nós!". A forma como se viam estava muito relacionado as representações sociais que os cercam. Não se tem dados que indique uma relação direta entre ciganos e cangaceiros, o que me parece é que naquele momento a cigana estava operando com os estigmas que lhe são atribuídos. Mas não era a primeira vez que ouvíamos sobre suas experiências com outros grupos. Já sabíamos que encontravam apoio nos quilombos e também mantinham contato com povos indígenas que viviam no sertão Nordestino. Um dos chefes de Sousa, o cigano $\mathrm{E}^{8}$, ao falar de

\footnotetext{
${ }^{5}$ Sousa é uma cidade localizada no sertão da Paraíba, Nordeste Brasileiro.

${ }^{6} \mathrm{O}$ cangaço foi um movimento social armado que ocorreu entre os séculos XVIII e XIX com área de abrangência na região semiárida do nordeste brasileiro, encontrado de modo mais frequente nos estados de Alagoas, Bahia, Ceará, Paraíba, Pernambuco, Piauí, Rio Grande do Norte e Sergipe (Santos, 2018).

${ }^{7} \mathrm{O}$ autor Locatelli, com uma visão determinista e até preconceituosa afirmou que "Sem compromisso com a terra e a sociedade, sem identidade, sem profissão definida, sem muito apego à família, os ciganos nordestinos hoje formam um contingente irregular de virtuais pistoleiros, pois andam bem armados. Conhecem muito bem a região e até certo ponto são mão-de-obra barata para o crime. Os atritos tornam-se inevitáveis e o cigano, que nada tem a perder e a deixar, passa a dar uma de cangaceiro ou jagunço: mata, rouba, foge. E lá se vai, foragido, suscitando revolta em vez de compaixão e ajuda" (Locatelli, 1981: 48)

${ }^{8}$ Chefe é como são chamados as maiores autoridades das comunidades ciganas. O cigano sempre mostrou interesse em cooperar com a pesquisa. Neste dia, estávamos sentadas em frente à sua casa com um grupo de homens que falavam de um "passado" compartilhado. Ao acionar o "tempo de atrás" (Goldfarb, 2004), pareciam querer evidenciar aspectos de uma "vida cigana". Falavam das longas viagens, da fome que passavam e de algumas estratégias de sobrevivência, num processo de negociação entre suas memórias individuais e a reconstrução de uma memória coletiva (Pollak, 1989).
} 
suas andanças nos revelou sobre o contato com indígenas de Pernambuco e de passagens entre algumas aldeias. A frase e o acionamento dessas memórias nos fez compreender que embora nos espaços públicos de discussão, os/as ciganos/as, com raras exceções, tenham permanecido no anonimato até os primeiros anos do século que vivemos, estes mantiveram relações com outros povos que estavam em processo de mobilização política, sem que necessariamente isso tenha provocado a conscientização de uma luta por terra ou por acesso a direitos sociais.

Sabe-se que no período da pré-constintuinte, houve a efervescência de muitos movimentos sociais que buscavam garantir participação naquela que viria a ser chamada de "Constituição Cidadã", porém, não nos parece se encaixar aí este que seria o início de um movimento cigano no Brasil. Foi no Rio de Janeiro, a partir da formulação do Centro de Estudos Ciganos - CEC 9 em 1986 que foi criada a primeira associação a apresentar um projeto político "informado pelo idioma nacionalista que imagina os ciganos como uma nação, englobando diferentes etnias" (Souza, 2013: 139), cujo objetivo era, sobretudo, o de fomentar pesquisas sobre a temática cigana. Formada por estudiosos e ativistas, a CEC logo foi extinta e em seu lugar, em 1990, foi criada a União Cigana do Brasil. Esta última com um forte engajamento no sentido de provocar uma espécie de fortalecimento cultural, como assim afirmou Mio Vacite, presidente da instituição. Mais precisamente, inicialmente, suas articulações buscavam fortalecer o povo cigano enquanto movimento cultural, já legitimado desde o Brasil colônia como "animadores do corte de Portugal" (Pieroni, 2006). Deste modo, a UCB surgiu buscando promover a arte da música e dança como elementos fundamentais da cultura cigana, o que sem dúvidas é muito relevante, porém não alterou a participação política destes indivíduos e nem altera o status quo.

Por isso, ser importante destacar que dentro desse cenário de atuação política existem diversas formas de agir. Formas que também são resultados de uma experiência ainda recente, pois é atual no Brasil o engajamento a partir de uma ideia de justiça social e de acesso ao sistema de garantia de direitos. E, neste sentido, temos, a partir dos anos 2000 o fortalecimento de certos atores sociais que passaram a se reconhecer enquanto representantes de seus grupos locais, agindo também inspirados no avanço e conquistas de outros movimentos, como os que foram realizado pelo povo negro e indígena.

Cenário que modifica o contexto das comunidades e o modo como se organizam politicamente. Aliás, essa ação e a demanda por participação política foi sendo construída como res-

\footnotetext{
${ }^{9}$ Graças a sua atuação ainda foi possível a retirada de conteúdo preconceituosos na terceira edição do dicionário Aurélio, cuja palavra "Cigano" apresentada a partir da definição "velhaco, trapaceiro e comerciante de objetos subtraídos", foi substituída por "indivíduo de um povo nômade que tem um Código ético próprio, vive de artesanato, de ler a sorte, e se dedica à música: homem de vida incerta” (Documento da ABA, 2019:01).
} 
posta aos contextos municipais, estaduais e federais. Na Paraíba, por exemplo, cenário de minhas pesquisas iniciais, o fortalecimento de algumas das lideranças ciganas foi também consequência de contatos com políticos locais que ofereciam benefícios, em troca de apoio político. O fato é que esse poder que foi dado a tais agentes, também permitiu o acesso ao universo político externo e contribuiu para um entendimento de que são "sujeitos de direito", neste caso, passaram a negociar não apenas visibilidade cultural, mas, sobretudo, direitos fundamentais: saúde, educação, moradia, segurança, entre outros.

O fato é que observando a mobilização de certos atores sociais, agentes que visam realizar a "mediação" entre as comunidades que querem representar e o Estado, compreendemos que este é um movimento com características muito especificas, sobretudo, pela dificuldade que tais agentes encontram diante de seus grupos que possuem poucas expectativas no que se refere a possibilidade de ações efetivas que possam trazer melhorias para sua vida. Além de já conheceram a hostilidade quando demarcam sua identidade em espaços públicos.

Nesse sentido, "projetos políticos" (Souza, 2013) estão sendo formulados e negociados a partir da construção e demarcação de suas identidades em espaços até então evitados ou não ocupados. Para tal, procuram despertar nos indivíduos sentimentos de um "orgulho cigano" ou um "orgulho romani" a partir do acionamento de uma memória coletiva. Um processo que também é de formulação de uma história oficial que deve ser apresentada como forma de legitimação da sua identidade que deverá ser demarcada e reconhecida perante o Estado brasileiro.

A cultura aqui pensada enquanto fluxo sem a possibilidade de estagnação dos seus materiais (Barth, 2005), está sendo constantemente gerada, apropriada e reproduzida a partir das experiências individuais para a ação política coletiva. Na ponta desse processo, estão estes agentes que atuam na mobilização das diferenças para que elas se tornem mais aparentes. "Eles mobilizam as bases étnicas por meio da insatisfação, de modo a poderem guiá-las na direção de uma satisfação prometida" (Ibid.: 26), satisfação essa que poderá ser atingida a partir do acesso as políticas sociais geradas para minimizar os efeitos da discriminação e perseguição apontadas pelos agentes como aspectos que limitam suas formas de existência.

Mediante o cenário de políticas públicas, mediação e negociação da identidade cigana ou da identidade romani, tem sido interessante observar novos papeis sociais sendo assumidos. Papeis desempenhados na maioria dos contextos por homens que passam a ser apropriados por mulheres que reivindicam o reconhecimento de seus grupos, enquanto "Povo tradicional" acionando um repertório de políticas que devem ser acessadas, como aquelas advindas da Política Nacional de Desenvolvimento Sustentável de Povos Comunidades Tradicionais publicada por 
meio do Decreto $N^{\circ} 6040$ de 07 de fevereiro de 2007 e que representa um marco na luta dos grupos étnicos no Brasil.

A necessidade de alguém que esteja compromissado com o fortalecimento de uma coletividade, mas também que tenha conhecimento necessário para agir e atingir o universo jurídico de modo que seu grupo acesse esse conjunto de dispositivos que pode garantir melhores condições de vida, desperta a necessidade de atuação. Diferentemente do chefe cigano comumente mais idoso, que não necessariamente foi alfabetizado, mas que estava à frente de seu grupo, sobretudo, no período em que a mobilidade se fazia regra pela relação hostil com moradores das cidades que se instalavam, ou do líder cigano, homem (jovem ou não) que está em constante diálogo com outros agentes, a mulher cigana que assume essa posição sabe dos seus direitos, não necessariamente age a partir de um recorte e demanda de gênero, e instiga aqueles que têm representado a operar a partir de uma lógica em que se pensem enquanto "sujeitos de direitos" e não mais "miseráveis que precisam de esmola", como afirma uma liderança feminina da Bahia,

Geralmente jovens, alfabetizadas, essas mulheres rompem com o protagonismo masculino e assumem papéis importantes a frente de seus grupos. Na verdade, pensar que há uma situação de passividade da mulher no "sistema social cigano/a" é um erro, pois é ela quem tem a responsabilidade de manutenção de seu núcleo familiar, bem como atua no fortalecimento do sistema cultural de grupo, haja visto que cabe a mulher cigana ensinar aos filhos sobre as tradições e a importância de vivenciá-las no cotidiano. No entanto, permaneciam com escassa participação política e nos processos de negociação, os homens ciganos tradicionalmente ocuparam estes espaços.

É comum ouvir das ciganas e das mulheres romani que temos pesquisado que foi no governo da primeira presidente mulher do Brasil $^{10} \mathrm{o}$ chamamento para a participação da construção de uma pauta política na qual suas demandas poderiam ser ouvidas. A presidente Dilma Roussef parece ter garantido a participação política de muitas mulheres ciganas que, ao contrário de outras mulheres pertencentes a minorias étnicas, como as indígenas e negras, permaneciam a parte das discussões.

As mulheres daqui, aliás, de toda comunidade tradicional estão com a obrigação de participar. A Presidente Dilma, pessoa que tenho muito carinho... primeiro Deus, Lula e ela para olhar pelo povo cigano, pois é. A Dilma, com aquele jeito dela, organiza os eventos e coloca a mulher para

\footnotetext{
${ }^{10}$ A presidenta Dilma Roussef filiada ao Partido dos Trabalhadores exerceu seu mandato de 2012 a 2016 quando enfrentou um processo de impeachment que ficou conhecido como o "golpe de 2016".
} 
falar. A gente tá tendo espaço, Jamilly. Antes não tinha isso.

(Cigana A., dezembro de 2015)

Dentre tantas associações representativas ciganas, durante muito tempo, foi escassa a participação destas mulheres que passaram a se organizar e demandar uma pauta que levasse em conta seus "lugares de fala"11. Observamos a existência de uma representação que há 11 anos foi criada enquanto uma organização presidida e administrada apenas por mulheres e pensada para as mulheres ciganas, ou como elas mesmas demandam, "mulheres Romani”. Neste sentido, assumir as intersecções dentro da própria diferença é dizer que as várias narrativas importam, e é assim que a as fundadoras da Associação Internacional Maylê Sara Kalí-AMSK definem sua pauta de luta. São Mulheres Romani, que vivem sua identidade a partir de experiências até então não observadas por nós, tendo em vista que até aquele momento, estávamos lidando com mulheres dentro dos contextos de suas comunidades locais. São ativistas que não se vinculam a uma única comunidade local, não vivem em ranchos ou acampamentos, não são casadas e nem acham que isso deve ser um impasse para que sejam respeitadas e ouvidas, além disso, rejeitam o uso do termo "cigana" como forma de identificá-las.

Sou uma mulher, uma mulher de etnia Romani. É muito tranquilo que as pessoas compreendam o nome cigano. Mas esse nome foi dado por não ciganos, já com o recorte de exclusão. Internamente ele não é nem dito e usado nas comunidades. Mas ele é usado por várias estruturas de governo. E realmente aculturação e assimilação é o que mais chega e o que mais chega a todos nós. (E., 26 de outubro de 2017, Brasília)

Fundada em 2009, a AMSK nos chama atenção, sobretudo, pela sua capacidade de articulação, mobilização e pela pauta que assume. Como indicado anteriormente, a maioria das associações ciganas tem realizado um trabalho mais local, e não estamos dizendo que isso seja um erro, aliás, as demandas que essas instituições apresentam são urgentes e referem-se à sobrevivência desses indivíduos que vivem em seus acampamentos e ranchos, muitas vezes, em situações extremas de pobreza. Contudo, a AMSK tem participado ativamente da construção de pautas importantes e que surgem como aquilo que Nancy Fraser (2006) chamou de "remédios transformativos", no sentido de buscarem atingir a estrutura que engendra processos de desigualdade social e cultural, e não apenas contribuir para a construção de uma política afirmativa. Suas fundadoras são contundentes em afirmar que não basta agir no sentido de resolver questões pontuais que assolam tais indivíduos e suas famílias, é preciso ir mais além, buscando acabar

\footnotetext{
${ }^{11}$ Sobre o tema, ver RIBEIRO, Djamila. O que é lugar de fala? Belo Horizonte (MG): Letramento, 112 páginas, 2017. (Coleção: Feminismos Plurais).
} 
com o preconceito que determina as relações entre ciganos/as e não ciganos/as. Para tal, exigem, por exemplo, que o termo cigano/a, pelo seu caráter exógeno, e por ser dotado de estereótipo, deva ser substituído pela de ideia de um "orgulho Roma", utilizando os termos "Roma e Romani"12 nos processos de autodefinição.

Por remédios afirmativos para a injustiça, entendo os remédios voltados para corrigir efeitos desiguais de arranjos sociais sem abalar a estrutura subjacente que os engendra. Por remédios transformativos, em contraste, entendo os remédios voltados para corrigir efeitos desiguais precisamente por meio da remodelação da estrutura gerativa subjacente. O ponto crucial do contraste é efeitos terminais vs. processos que os produzem - e não mudança gradual vs. mudança apocalíptica.

(Ibid.: 237)

Aliás, essa é uma discussão complexa e tem sido realizada por alguns pesquisadores (Fazito, 2006; Sória, 2008; Guimarais, 2012; Grisolia, 2013). Pois no cotidiano, tais indivíduos usam as demarcações de grupo (Rom, Calon ou Sinti) nos processos de identificação e se perguntarmos a um Calon a qual grupo pertence, provavelmente, se não estivermos diante de um agente político que já reconhece a existência desse debate, ele irá responder que é um Cigano ou um Calon. Dessa forma, compreendemos que este é um debate que não está no cotidiano das comunidades e acampamentos e nem nas suas preocupações de vida. É uma pauta de agentes políticos e ativistas que afirmam ter um entendimento do processo histórico e, nesse sentido, a realidade das comunidades serem fruto do colonialismo e das demais perseguições históricas que viveram, por isso, acabam reproduzindo o que aprendem nos processos interacionais a partir de relações de poder.

Sobre o tema, Sória (2008) traz uma provocação interessante. No título de sua dissertação de mestrado, na frase "Entre a dor de ser cigano e o orgulho de ser Romà" a autora reflete justamente o pensamento dos agentes da AMSK que compartilha com Sória o pertencimento a uma identidade extremamente estigmatizada e, por isso, em seus posicionamentos uma estratégia de enfrentamento a este cenário a partir do reconhecimento da negatividade que o termo “cigano/a" traz consigo. Sória (2008: 11) diz:

[...] Emprego o termo Romá para substituir ciganos, qualitativo imposto desde fora, e tido como pejorativo. Esta nova denominação é de certa forma reducionista porque não abrange amplamente a diversidade de grupos que constituem o coletivo étnico, no entanto, considero a iniciativa

\footnotetext{
${ }^{12}$ Segundo Guimarais (2012, p.102), o termo "Roma" se refere aos ciganos ligados às organizações ocidentais, que fazem uso deste termo politicamente correto perante as entidades da União Europeia e alteram a identidade e representatividade política.
} 
de estandardização. A partir daqui utilizo a forma "ciganos" para realçar a negatividade da acepção.

Fisher (2011: 04) em "Between Nation and State: Examining the International Romani Union's Claim to Non-Territorial National Recognition" aponta que o termo Roma se refere a um grupo diversificado de identidades étnicas e o termo Romani é sua forma adjetiva. Afirma ainda que a diversidade étnica, características desses grupos, fez com se formassem verdadeiros “arquipélagos étnicos”, com distinções internas (a língua é uma delas) e que algumas dessas "ilhas" rejeitam o uso deste termo, justamente por associarem o termo Roma como derivado do "Romanichal".

Uma das representantes da AMSK reconhece as distinções internas e as variações produzidas também pelos contextos que vivem e a forma que interagem. Afirma que não é uma questão de diluir as diferenças, mas sim de reconhecer uma estrutura que acompanha o processo diaspórico ${ }^{13}$ de seu povo. Portanto, a associação assume que no Brasil há um problema de nomenclatura cuja orientação internacional ${ }^{14}$ revela a necessidade de utilizar o termo Rom ou Romani nos processos de nomeação e identificação. Abordar esta questão é importante no sentido de revelar a ação dessas mulheres que atuam de modo a refutar esse sistema vigente que se apresenta de modo mais cruel quando pensamos seu pertencimento étnico e, internamente, sob nova face de opressão para que se viva a partir de um modelo "tradicional” que informa o "ser mulher cigana". Nesse sentido, o reconhecimento enquanto "mulher romani" também opera como resposta a romantização e folclorização da identidade.

Um dos temas que desejamos abordar aqui, refere-se as questões ligadas a uma nova forma de vinculação percebida atualmente na qual essas mesmas mulheres se reconhecem enquanto pertencentes a um movimento político de caráter transnacional que visa ter "dignidade frente a opressão multifacetada e para reivindicar o próprio empoderamento, contestando os processos de racialização e de exclusão dos direitos básicos" (Rea, 2017). Estamos nos referindo ao seu reconhecimento enquanto "feminista romani" e, nesse sentido, passaremos agora a discorrer o

\footnotetext{
${ }^{13}$ Segundo Batista e Medeiros (2015), entre os ciganos "as diásporas tem sua ocorrência como estrutura de organização que comportam tanto a solidariedade em condições adversas, como também a mobilidade social, além da integração no sistema do poder, o que pode também implicar na participação nacional e internacional no sistema político.

${ }^{14}$ Em "Marcos legais de proteção e promoção dos direitos do povo rom (os assim chamados ciganos)" Costa e Cavalcante apresentam um mapeamento das políticas públicas brasileiras destinadas ao Povo Rom. Na publicação elas trazem como exemplo da nomenclatura utilizada pela ONU o Pacto Internacional dos Direitos Civis e Políticos, CCPR/C/BRA/CO/2 que no parágrafo 20 diz: O Estado parte deve fornecer informações sobre a situação da comunidade Roma e as medidas tomadas para assegurar seu exercício prático dos direitos estabelecidos pelo Pacto.
} 
que até o momento observou-se sobre o tema. Afinal, o que significa se reconhecer enquanto uma "feminista romani"?

\section{"Feminismo Romani"? Algumas reflexões iniciais}

Antes de tudo, devemos dizer da complexidade da questão, tendo em vista que na prática ainda é um tema desconhecido e distante da realidade de muitas meninas e jovens ciganas que vivem no Brasil. E, quando pensamos o crescimento de uma visão deturpada do movimento feminista promovido nas redes sociais e que o classifica enquanto movimento homogêneo necessariamente ligado às questões de sexualidade, compreendemos a dificuldade expressada por nossas interlocutoras de se reconhecer enquanto feminista em suas famílias e comunidades, mesmo quando percebemos uma atuação que vise mudanças nas formas que são tratadas dentro e fora de seus núcleos familiares.

É preciso enfatizar a dupla dificuldade que essas mulheres enfrentam. A sociedade majoritária, não diferente de sua comunidade ou família, tenta impor uma forma de pensar e agir que seja moralmente adequada e aceita. Por outro lado, durante muitos anos aspiraram mudanças a partir da representação de chefes e líderes masculinos que, muitas vezes, não levaram em conta suas demandas tendo em vista a tentativa de apresentar um grupo coeso e homogêneo. Não diferente ocorreu com mulheres indígenas e afro-americanas, como destacado por Segato (2012: 117) que

[...] atuaram e refletiram divididas entre, por um lado, a lealdade às suas comunidades e povos na frente externa e, por outro lado, sua luta interna contra a opressão que sofrem dentro de suas comunidades e povos, denunciam frequentemente a chantagem das autoridades indígenas, que as pressionam para que posterguem suas demandas como mulheres sob o argumento de que, ao não fazê-lo, estão colaborando para o enfraquecimento da coesão em suas comunidades, tornando essas mais vulneráveis nas lutas por recursos e direitos.

No caso das mulheres por nós investigadas, nos seus campos de ação e associativismo, procuram realizar uma reflexão crítica sobre a existência e permanência de certas regras e normas que impõe limites na atuação de meninas e mulheres ciganas que, sob orientação de seus pais e sogros, precisam manter-se distante dos espaços de poder. Entre essas mulheres há o reconhecimento de que certos temas permanecem sendo tabus e, por isso, a necessidade de realizar as discussões dando voz e espaço para aquelas que se mantiveram caladas e sem representatividade. É claro que precisamos evitar generalizações, contudo, assuntos que envolvem o corpo e sexualidade, continuam sendo temas distantes das rodas de conversa de mulheres e homens ciganos/as. 
Pensando sobre suas formas de agencia, compreende-se que no Brasil as mulheres ciganas que se reconhecem enquanto feministas, apontam em seus relatos a dificuldade que há na compreensão de seu ativismo. Pois, como nos foi revelado por uma interlocutora: "no senso comum ser cigana e ser feminista é algo que parece ser contraditório". Nesse sentido, essas mulheres se reconhecem justamente a partir da heterogeneidade do movimento e é neste caminho que começaram a atuar. Atualmente, entre as ativistas que temos pesquisado, os termos feminismos e Romani aparecem indissociáveis nas suas formas de identificação. Pois, neste processo "caminham respeitando as tradições", como ouvimos de uma ativista por nós investigada. A referência à tradição está relacionada à perspectiva da família enquanto unidade elementar e fundamental de reprodução cultural e social de seu grupo. Em sua fala a agente procura deixar evidente que sua forma de ser procura se afastar de um "feminismo convencional", reafirmando a relação da "mulher romani" com seu núcleo familiar e a importância dessa instituição na sua forma de ser e agir.

Elencar a tradição como componente de seu ativismo, significa dizer que as mudanças almejadas não devem significar o rompimento com uma "vida romani", que como vimos, apresenta diferentes formas de ser. Significa também buscar legitimação para sua ação diante de outros líderes masculinos que tentam responder as expectativas externas no acionamento de uma identidade coletiva no qual certos aspectos tradicionais devem ser vivenciados por que eles são componentes da diferença.

Contudo, nesse ínterim, compreende-se que há um processo de reivindicação e construção de políticas ligadas a alguns temas específicos. Entre as ativistas mulheres, saúde e educação surgem como pautas fundamentais no processo de sobrevivência e emancipação de seu grupo. Como vimos em alguns de seus relatos, há a necessidade de um esforço maior na garantia da continuação de meninas que são retiradas das escolas por seus pais ${ }^{15}$ que tentam agir no sentido de preservá-las do contato e interação com não ciganos/as que por ventura possam afastá-las do convívio familiar. Esta fase geracional, como liminar que é, acaba sendo bastante complexa para ambas as partes. Mães e pais que tentam "proteger" suas filhas, filhas que sentem o de-

\footnotetext{
${ }^{15}$ Como dissemos, é preciso evitar generalizações. Em alguns contextos, como nas comunidades ciganas de Sousa e Condado, Paraíba, meninas são incentivadas no processo de escolarização. Mães e pais mostram com orgulhos diplomas de formação de suas filhas. O relato de Alexandrina Fonseca (2009: 234)) em "La mujer gitana en el siglo XXI" nos mostra como sua família procurou incentivá-la na busca por uma formação educacional. Ela nos diz: "Nací en Portugal, en una familia gitana con una visión de la sociedad pionera en su tiempo. Fui educada en la reflexión de la realidad, en la convicción del propio pensamiento y en la libertad de ideas para encauzar y conducir mi vida hacia lo que hoy es. Gracias a mi padre que consideraba la necesidad de educar a sus hijas como a sus hijos he llegado a ser lo que soy".
} 
masiado cuidado e a desconfiança de seus pais. Entretanto, mesmo sendo um desafio para grupos subalternizados (Gusmão, 1997: 43) de um modo geral, o tema da educação é recorrente nas falas das ativistas, que prometem ser esse um meio de superação para as dificuldades que enfrentam.

[...] O acesso à educação e à escolarização é visto, ainda hoje, como possibilidade de conhecimento e ascensão social, capazes de superar a subalternidade e projetar outro lugar no mundo.

Tal pensamento generalizado, ambíguo e ambivalente, pouco ou nada diz em termos dos desafios, dos conflitos e dos limites do campo educacional, em termos de escolarização e de educação

(Gusmão, 2016: 42)

Pois esta é outra dificuldade e demanda discutida pelas ativistas que temos pesquisado. Pensar o acesso e a permanência numa educação escolar significa reconhecer também as dificuldades encontradas por aqueles/as que utilizam este espaço. A escola é um campo de tensões e de poder e, por isso, ser fundamental uma "educação voltada para o respeito e a valorização das diferenças", como indicou um dos membros da AMSK. Para a superação de tais dificuldades, algumas mulheres feministas Romani do Brasil, em alguns espaços públicos, têm falado em educação intercultural como elemento fundamental da construção de sistemas educativos justos.

Tal fato nos chama atenção, tendo em vista a construção aprofundada de uma pauta importante e que pode reverberar em mudanças significativas para tais atores sociais, haja vista que a interculturalidade alinhada à perspectiva educacional é caminho seguro para a construção de sistemas educativos nas sociedades que se comprometem com uma construção democrática, bem como com a equidade e o reconhecimento dos diferentes grupos e minorias socioculturais que os integram (Candau, 2012:08).

Tais ativistas também têm atuado na construção de uma área fundamental para a sobrevivência da população cigana. No âmbito da saúde as questões de gênero têm sido refletidas através das construções realizadas e que demandam um olhar específico para a mulher cigana. Há na Política Nacional de Atenção Integral a Saúde do Povo Cigano/Romani este importante recorte, tendo em vista a necessidade de atenção básica à saúde da mulher cigana que, por sua vez, durante nossa pesquisa denunciou o racismo institucional como condutor das ralações nos espaços destinados ao combate e tratamento de doenças, além de casos de violência obstétrica e negligência médica, o que acaba por afastá-las desses lugares. 


\section{Considerações finais}

Como vemos, são construções em que se busca romper com a invisibilidade da mulher cigana internamente, bem como perante o Estado brasileiro no processo de construção de políticas sociais. Pretende também criticar o tratamento histórico que foi dado à mulher cigana através da hipersexualização de seus corpos e do exotismo frequente associado à sua imagem.

Uma atuação que começa a ensaiar formas de inserção nos acampamentos, ranchos e comunidades no sentido de empoderar jovens ciganas para que percebam suas múltiplas e diversas possibilidades de existência. Contudo, acreditamos que essa é uma barreira difícil de ultrapassar. Reconhecemos que o feminismo romani no Brasil ainda possui pouca representatividade no contexto das comunidades espalhadas entre as cinco regiões que compõem o país, mas ele existe e tem dado passos importantes para quebrar barreiras que antes pareciam inacessíveis. O Brasil, este país de proporções continentais, apresenta uma diversidade de formas de organização interna, articulação e mobilização que impõe um desafio ainda maior para aquelas que pretendem atingir estruturas locais. Por isso também a importância que se dá a formação escolar, no sentido de que para além da alfabetização, a escola possibilite o desenvolvimento do senso crítico das meninas ciganas, para que essas também se "tornem agentes de mudança", como nos foi revelado.

Importa saber que o ativismo feminista romani que tem sido realizado na atual conjuntura brasileira, tem procurado garantir que o que fora construído não seja arquivado. Aquém de uma atuação mais objetiva e que vise o empoderamento da mulher cigana dentro dos ranchos e acampamentos, mais do que em qualquer outra época por mim observada, essas mulheres têm procurado ocupar espaços que garantam a comunicação com o Estado e o acesso a direitos, contudo, o desmonte de alguns Conselhos que garantem a participação social e setores destinados ao tratamento e construção de políticas para as minorias étnicas impossibilita a continuação deste trabalho de vigilância. 


\section{Bibliografia}

Barth, F. (2005), Etnicidade e o conceito de cultura. Antropolítica, n. 19, p. 15-30.

Candau, V. M. (2012). Direitos humanos, educação e interculturalidade: as tensões entre igualdade e diferença. Revista Brasileira de Educação v. 13 n. 37 jan./abr..

Costa, E.; Cavalcante, L.\& Cunha, J. R (2017). “Acampamentos "ciganos" 2017: os desafios da implementação de direitos”. Revista de Estudos e Investigação Antropológica, Ano 4, Edição Especial II.

Fischer, A (2011). "Between Nation and State: examining the International Romani Unions". Senior Projects Spring 2011. Paper 12. 7

Fonseca, A. (2009). La mujer gitana en el siglo XXI. Anales de Historia Contemporánea, 25.

Fraser, N. (2001). "Da redistribuição ao reconhecimento? Dilemas da justiça na era póssocialista”. In: Souza, Jessé (Org.). Democracia hoje: novos desafios para a teoria democrática contemporânea. Brasília: Editora Universidade de Brasília.

Goldfarb, M. P. L (2004). Tempo de Atrás: um estudo da construção da identidade cigana em Sousa-PB. Tese de Doutorado, Sociologia, Universidade Federal da Paraíba PPGS/UFPB,.

Grisolia, J. D. (2013). Os "filhos do vento" e sua festa à beira-mar: celebração e visibilidade das "culturas ciganas" na sociedade carioca contemporânea. Monografia apresentada ao Curso de Graduação em Produção Cultural da Universidade Federal Fluminense.

Guimarais, M. T. S. (2012). O associativismo transnacional cigano: Identidades, diásporas e territórios. Tese apresentada ao Departamento de Geografia da Faculdade de Filosofia, Letras e Ciências Humanas da Universidade de São Paulo: São Paulo.

Gusmão, N. M. M. (1997). Antropologia e Educação: origens de um diálogo. Caderno CEDES. v.18, n.43, Campinas, dez..

Hall, S. (2005). A Identidade Cultural na Pós-modernidade. Rio de Janeiro: DP\&A.

Locatelli, M. A. (1981). O ocaso de uma cultura: uma análise antropológica dos ciganos. Santa Rosa: Barcellos Editora.

Medeiros, J. C. \& Batista, M. R. R. (2019). Ciganos e o poder público: exercício de pesquisa a partir de situações envolvendo deslocamentos e fixações e o uso dos salvo-condutos. In: Ciganos olhares e perspectivas / Goldfarb, M. P. L.; Toyanski, M. \& Oliveira L. (organizadores). João Pessoa: Editora UFPB.

Moonen, F. (2013). Anticiganismo e políticas ciganas na Europa e no Brasil. Recife: Núcleo de Estudos Ciganos (NEC).

Mendonça, C. L. (2016). "Guerreiras Indígenas Reunindo as Forças”: agência de mulheres indígenas e políticas públicas de educação escolar intercultural. In: Educação, feminismo e o estado no Brasil / Parry Scott (organização). Recife: Editora UFPE.

Pollak, M. (1989). Memória, Esquecimento, Silencio. Estudos Históricos, Rio de Janeiro, vol. 2, n. 3 , p. $3-15$ 
Pieroni, G. (2000). Vadios e ciganos, heréticos e bruxas: os degredados do Brasil colônia, Rio de Janeiro, Bertrand Brasil.

Rea, C. A. (2017). Redefinindo as fronteiras do pós-colonial. O feminismo cigano no século XXI. Rev. Estud. Fem. [online]. vol.25, n.1, 31-50. ISSN 0104-026X..

Santos, W. A. (2018): “Cangaço: um movimento social”, Revista Caribeña de Ciencias Sociales (febrero 2018). En línea: //www.eumed.net/2/rev/caribe/2018/02/cangacomovimento-social.html

Segato, R. (2012). Gênero e colonialidade: em busca de chaves de leitura e de um vocabulário estratégico descolonial, e-cadernos ces [Online], 18. 106-131

Soria, A. P. C.B (2008). Entre a dor de ser "cigano" e o orgulho de ser romà: aproximação à literatura romani e a auto-representação dos romà em duas obras de Jorge Nedich. Dissertação de mestrado. Brasília: Universidade de Brasília.

Souza, M. A. (2013.). Ciganos, Roma e Gypsies: projeto identitário e codificação política no Brasil e Canadá. RJ - Niterói. Tese (Doutorado em Antropologia) - UFF PPGA. 


\title{
Capítulo 9. \\ Contextos e participação social
}

\author{
ELISA COSTA ${ }^{1}$ \\ Fundadora da Associação Internacional Maylê Sara Kalí - AMSK/Brasil, e atual Presidente da organização \\ elisa@amsk.org.br
}

Resumo: A participação dos "assim chamados ciganos" nos contextos atuais e futuros, carece de discussão e análise. Essa é uma realidade urgente. A mediação de conflitos, tem sido, atropeladamente, uma forma diária de participação e interposição entre estado e membros da etnia, sociedade em geral e os anseios das comunidades e indivíduos de etnia romani. $\mathrm{O}$ que de fato seria necessário? Qualificar é a palavra. No Brasil, seria a efetivação dos vários atores dessa agenda. Sem aculturamento, sem terminologias excludentes como: e outros, as minorias, os demais. Nomear e construir uma agenda com escuta qualificada, encaminhamentos realistas, sinalização do governo federal com recursos para realizar as agendas e efetivação das leis com o devido cumprimento seria a base de uma política séria de fato e voltada para as demandas que se estabelecem em todos os meandros, tanto da política, quanto da vida social. A distância entre a realidade política do Brasil e a realidade de formação/participação desses sujeitos de direito, cria lacunas e lança no cenário mundial um aumento da ciganofobia e do estereótipo crescente. A fantasia representada no Brasil, os comunicados de autoridades, intitulados como grandes defensores, o sumiço da história política do país, criam o cenário no Brasil, que foge das construções sérias, da realidade discriminatória e excludentes, que muitos vivem no país. Romper esse ciclo de racismo institucional ou de anticiganismo ou mesmo de rromafobia é ponto primordial para criar uma "agenda", que respeite as diferenças e as dimensões territoriais, que influenciam cotidianamente no modo de ser, estar e permanecer da Roma no Brasil.

Palavras chaves: Participação Social, Mediação, Brasil Romani.

\begin{abstract}
The participation of the "so-called Gypsies" in current and future contexts needs discussion and analysis. However, this is an urgent reality. Conflict mediation has been a daily form of participation and interposition between state and ethnicity members Romani, society in

\footnotetext{
${ }^{1}$ Elisa Costa é Brasileira, Bacharel em Ciências da Saúde Natural. Terapeuta Acupunturista, Homeopata NM e Especialista em Fitoterapia e Liderança Executiva para o Desenvolvimento da Primeira Infância - INSPER. Fellow ASHOKA. É ativista, militante e Defensora dos Direitos Humanos para a Rromá. É Feminista Români. Presidente fundadora da AMSK/Brasil - Associação Internacional Maylê Sara Kalí - desde 2009.
} 
general and the aspirations of Roma communities and individuals. What would actually be needed? Qualifying is the word. In Brazil, it would be the accomplishment of the various stakeholders of this agenda. No acculturation, no exclusionary terminologies like: and others, minorities, others ... To name and build an agenda with qualified listening, realistic referrals, sinalizing the federal government with resources to carry out the agendas and enforcement of laws with due compliance would be the basis of a serious policy that is in fact, focused on the demands that are set in all the specifications of both politics and social life. The distance between the political reality of Brazil and the reality of formation / participation of these subjects of law creates gaps and launches on the world stage an increase of romaphobia and the growing stereotype. The fantasy represented in Brazil, the information given by the authorities, entitled as great defenders, the disappearance of the political history of the country, set the scenario in Brazil, which is beyond the serious constructions, discriminatory reality and exclusionary that many live in the country. Breaking this cycle of institutional racism or anti-Gypsy or even romaphobia is a crucial point to create an "agenda" that respects the differences and territorial dimensions that influences daily the way of being, being and remaining of Roma people in Brazil.

Keywords: Social participation, Mediation, Brazil Romani.

\section{Do espaço de luta}

Para esse pequeno esboço da situação atual da Rromá ${ }^{2}$ no Brasil “os assim chamados ciganos", tomamos por base a reunião interna de escuta que a AMSK/Brasil faz anualmente e que visa, de acordo com suas diretrizes internas, trabalhar junto a seus membros, parceiros e amig@s, construir estratégias, analisar situações de risco e verificar participações. Nos baseamos na situação vivida pelo Brasil a partir do Impeachment da então presidenta do Brasil, Dilma Rousseff em 2016, a quebra de agendas que seguiam sendo construídas e seus avanços, assim como os desdobramentos e os aprofundamentos de agendas essenciais para a Rromá no Brasil. Em termos de organização social, a AMSK/Brasil tem como valor primeiro a discussão política qualificada, busca e análise de dados, os grupos de discussão, a aproximação com o estado e as saídas possíveis construídas junto à sociedade não Rromá.

\footnotetext{
${ }^{2}$ Roma é o termo politicamente correto para designar os ciganos. Rom é sua forma no singular, e designa toda pessoa pertencente a esta etnia. São encontradas também as variações com o " $\mathrm{r}$ " duplicado: Rrom e Rroma. É importante lembrar que nem todos os ciganos conhecem estes termos ou se consideram Rroma. Romani é usado como adjetivo, também apresentando variações em sua grafia, com "r" duplicado, Rromani, ou com "y" Romany. Designa, ainda, a língua falada pelos Rroma, também conhecida como Romanês e Romanó. (Vasconcelos e Costa, 2015: 7).
} 
Essas reuniões também são um sensor do pensamento no país, com diferenças de etnias, formação acadêmica e religiosa, além é claro da igualdade de gênero. Através delas podemos identificar várias condicionantes do quão danoso e extenso é a rromafobia e como ela pode comprometer de forma constante os pequenos e tímidos avanços. Nossas armas precisam ser baseadas na educação, no conhecimento da própria Rromá e de como ela se relaciona com a sociedade, com o estado nação e com a mídia.

Não é o que pensam sobre nós, é o que somos. Não se trata das análises dos outros, se trata de como esse pequeno grupo misto "de Rromá e gadjo" pensa, observa e vive esses cotidianos dentro da AMSK/Brasil. Neste artigo, as maiores referências somos nós mesmos. São os nossos trabalhos, o nosso convívio diário e as realidades das pessoas, famílias e comunidades romani.

Essa não é uma agenda invisível. Somos invisibilizados, o que faz toda a diferença.

(Elisa Costa, AMSK/Brasil)

\section{Um Brasil de "meias verdades"}

Será de grande valia esclarecer que estudos mais elaborados sobre a política e seus conceitos de participação social dos "assim chamados ciganos" no Brasil, ainda carecem de muito estudo, seja nas áreas das relações sociais, de direito, das relações interpessoais e dos universos da política e da academia, onde a predominância é a exclusão das minorias, dos diferentes culturalmente e das etnias. Os trabalhos sobre essas questões são tímidos, inconclusivos e precisam ser feitos nas duas óticas, do rom e do gadjo que ocupam, de forma pouco paritária, os cenários da política e do universo acadêmico.

Temos construído ao longo dos anos alguns diálogos e assim, elucidando brechas e conceitos que foram introduzidos e trazidos como referenciais inquestionáveis. Aqui questionamos quase todos. Aqui quem fala são os sujeitos de direito, ou seja, as pessoas que vivem esse dia a dia e seus enfrentamentos, pelo fato de pertencerem a etnia romani.

Quem dera, duas "frases" pudessem pular dos livros e dos discursos e se tornar realidade para o povo romani no Brasil. A primeira se trata do artigo $5^{\circ}$ da Constituição Brasileira de 19883:

Art. $5^{\circ}$ Todos são iguais perante a lei, sem distinção de qualquer natureza, garantindo-se aos brasileiros e aos estrangeiros residentes no país a inviolabilidade do direito à vida, à liberdade, à igualdade, à segurança e à propriedade, nos termos seguintes:

\footnotetext{
${ }^{3}$ Disponível em: https://www.senado.leg.br/atividade/const/con1988/con1988_15.12.2016/art_5_.asp
} 
III - ninguém será submetido a tortura nem a tratamento desumano ou degradante;

XI - a casa é asilo inviolável do indivíduo, ninguém nela podendo penetrar sem consentimento do morador, salvo em caso de flagrante delito ou desastre, ou para prestar socorro, ou, durante o dia, por determinação judicial;

$X V$ - é livre a locomoção no território nacional em tempo de paz, podendo qualquer pessoa, nos termos da lei, nele entrar, permanecer ou dele sair com seus bens...

Por vezes somos brasileiros e por vezes somos eternos estrangeiros, seja entre estados, seja entre países. Os territórios não são livres para a Rromà (Cavalcante, 2019, p.18). Os acampamentos, bairros, casas e ranchos não são e não estão livres de investidas de policiais militares, sem qualquer razão, o que cai por terra a inviolabilidade da tenda (em especial), onde fala a Constituição Federal brasileira na inviolabilidade do lar. Tratamento desumano e desigual são fatores claros e recorrentes nos serviços de assistência pública, como hospitais, bancos, centros de referência sociais dentre outros. A isso chamamos de racismo institucional e/ou rromafobia, como queiram. Mas, precisamos aprender a dizer: rromafobia ${ }^{4}$. Esse termo vem sendo usado mais cotidianamente no Brasil e protagonizando assim as cenas de ódio, intolerância e racismo, direcionados ao cotidiano dos indivíduos da etnia romani. Os relatos e a vivência nos levam aos mais variados cenários da vida diária e as mais variadas situações, seja no simples fato de usar um transporte público, uma consulta ou internação hospitalar ou nos ambientes escolares. São os olhares de desprezo e as falas dirigidas de forma grosseira, que perpassam o cotidiano da etnia. Os chamados tratamentos degradantes estão a olhos vistos no cotidiano, sejam por identificações visuais/midiáticas ou de declaração de identificação individual. Não somos vistos e nem tratados como iguais, esse tratamento não se aplica a grande parte da etnia romani no Brasil e veremos isso no decorrer das participações sociais e suas dificuldades.

"Participação e direitos = Equidade", eis a nossa segunda frase, ela já nos coloca mais perto das discussões sobre o aculturamento - quando ditam como é nossa cultura sem compreenderem ou nos impõem uma cultura criada e travestida de nossa -, a igualdade e a globalização. Sendo exatamente a prática desse pensamento que possibilitou a alguns, despertar, trazendo no mínimo duas reações iniciais para a Rromá no Brasil, participação social e direitos sociais, nos dando o sentido da equidade tão necessária.

Temos o direito de ser iguais quando a nossa diferença nos inferioriza; e temos o direito de ser diferentes quando a nossa igualdade nos descaracteriza. Daí a necessidade de uma igualdade que

\footnotetext{
${ }^{4}$ Disponível em: https://baxtalo.wordpress.com/category/rromafobia-y-antigitanismo/
} 
reconheça as diferenças e de uma diferença que não produza, alimente ou reproduza as desigualdades.

(Santos, 2003: 56)

Seguindo nessa lógica, a partir de 2007, o Decreto n 6040 estabelece e nomeia os "Ciganos" como membros efetivos do que se reconhece como Povos e comunidades Tradicionais. Garante-se assim a participação em conselhos nacionais, estaduais e municipais. Apenas em 2009, a Convenção no 169 da Organização Internacional do Trabalho - OIT, de 07 de junho de 1989, promulgada no Brasil pelo Decreto $\mathrm{n}^{\circ} 5.051 / 2004^{5}$, consolidada no Decreto $\mathrm{n}^{\circ} 10.088 / 2019$, começa a ser vista como uma possibilidade de aplicação sobre as questões relativas a escuta qualificada das comunidades romani no Brasil e ganha força e desdobramento, através da Sociedade Civil organizada, no caso a AMSK/Brasil, que estabelece o estudo e as pesquisas para incidir na aplicação da Convenção no 169 da OIT nos anos de 2011, com o "Projeto Kalinka Ciganos na minha escola, uma história invisível”, sendo aplicado em uma escola do governo e com desenvolvimento pedagógico.

Em 2012, a AMSK/Brasil realizou o "Primeiro Seminário Internacional - Ciclo de Debates", onde representações romani do Brasil, Portugal, Espanha e Colômbia abordaram o tema da Rromá nesses países, os avanços, desafios e possibilidades. No mesmo ano outras três ações da AMSK/Brasil foram cruciais para avançar os debates:

A. Em 9 de Julho, reunião com a Ouvidoria Nacional da Secretaria Especial de Políticas de Promoção da Igualdade Racial - SEPPIR, Dr. Carlos Alberto de Souza e Silva Junior, presentes os representantes das comunidades Romani do estado de Minas Gerais e Goiás, Sr. Alexsandro Castilho e Nelio Jancovithe, e a AMSK/Brasil representada por Elisa Costa e Lucimara Cavalcante. Na oportunidade foi protocolado carta de solicitação ao cumprimento das Leis em vigência no país e um CD-ROM com arquivos de vídeos documentários sobre a violação dos direitos humanos dos Romani no Brasil;

B. Em 6 de Agosto, audiência com a Procuradoria Federal dos Direitos do Cidadão, Subprocurador Geral Luciano Mariz Maia, com representantes de famílias Romani comerciantes autônomos o Sr. Alexsandro Castilho e Nélio Jancovithe, a AMSK/Brasil representada por Elisa Costa e Lucimara Cavalcante, o Ouvidor Dr. Carlos Silva Jr. e Herta

\footnotetext{
${ }^{5}$ Todas as convenções e recomendações da Organização Internacional do Trabalho - OIT, aprovadas pelo Congresso Nacional, promulgadas por ato do Poder Executivo Federal foram consolidadas no Decreto ${ }^{\circ} 10.088$, de 5 de novembro de 2019.
} 
Rolim da Ouvidoria Nacional da SEPPIR, e Cristina representante da Secretaria de Políticas para as Comunidades Tradicionais da SEPPIR (SECOMT/SEPPIR);

C. Em 12 de dezembro de 2012, audiência pública "Direitos dos Povos Ciganos" realizada pela Comissão dos Direitos Humanos e Legislação Participativa do Senado Federal (CDH/Senado Federal), em atendimento ao pedido da Procuradoria Federal dos Direitos do Cidadão do Ministério Público Federal (PFDC/MPF), e da $6^{\text {a }}$ Câmara de Coordenação e Revisão das Populações Indígenas e Comunidades Tradicionais do Ministério Público Federal (6CCR/MPF). Após as considerações dos representantes governamentais (PFDC, Secretaria de Políticas para Comunidades Tradicionais da SEPPIR/PR, Secretaria Nacional de Economia Solidária do Ministério do Trabalho, Secretaria Executiva do Fundo de Desenvolvimento Social do Ministério das Cidades, Ministério da Cultura, Diretoria de Políticas de Educação do Campo, Indígena e para as Relações Étnico Raciais da SECADI/MEC) ficou estabelecido realizar audiências públicas nas Unidades Federativas do Brasil para ouvir os Romani nas diferentes regiões do país, a fim de obter subsídios para a elaboração do Estatuto dos Ciganos. E em 2013, como resultado da audiência pública, culminou no maior evento de escuta qualificada e específica com o evento "Brasil Cigano: I Semana Nacional dos Povos Ciganos", realizado no período de 20 a 24 de maio de 2013, em Brasília, Distrito Federal, promovido pela SEPPIR em parceria com organismos governamentais do poder executivo federal, e a AMSK/Brasil.

Nos anos acima descritos, tivemos condição de dar o pontapé inicial para a ampliação dessa tão falada participação social juntamente com as ações de controle social. Sair das construções estereotipadas e entrar nos dados reais, sempre foi um dos maiores desafios a serem vencidos.

Por esse motivo em 2012 a AMSK/Brasil cria o programa "Brasil Romani”" com ênfase na busca dos direitos, através das participações e das informações que viessem a romper com a perpetuação dos estereótipos. Quebrar a fantasia e a mística implantada é de fato uma condição fundamental para o avanço dessa agenda no Brasil.

No âmbito das discussões, após 2016, o Brasil aprecia uma reviravolta no governo e na política de estado ${ }^{7}$. As participações sociais sofrem assim, baixas e retrocessos gravíssimos, os

\footnotetext{
${ }^{6}$ Relatório executivo disponível em https://www.amsk.org.br/imagem/marcosLegais/SEPPIR_relatorio-executivo-Brasil-cigano.pdf

${ }^{7}$ Defino como o Golpe político que retirou a Presidenta Dilma Rousseff da Presidência da República do Brasil, sem condenação e prova de crime.
} 
quais seguem se aprofundando até os dias atuais. Falamos exatamente desse ponto, entre a garantia das discussões, que sofre um golpe com a queda do direito a continuidade e ao avanço da aplicação das políticas públicas para o povo romani do país. Ficamos no meio do caminho. Nem o Estado garante as agendas de participação, o judiciário namora com a possibilidade e insisti em dialogar com um Estado agressor e continuamos ouvindo a celebre frase: "os governos passam".

Não somos prioridade para o governo, sabemos disso. Nossa agenda rompe com mecanismos de luta amplamente utilizados pelos movimentos sociais - eis a tão sonhada equidade.

\section{(AMSK/Brasil)}

Nessa ótica é preciso reforçar o entendimento sobre o que discutir, quando discutir e como discutir. Precisamos avaliar qual o nosso papel no avanço das conquistas reais e ver onde e como dar os próximos passos. Somos um país de dimensões continentais e estamos em todos os 26 estados e Distrito Federal.

Sabemos que a agenda da "Rromá" no Brasil é "descartável". Ela apenas acontece de forma espontânea quando há grande divulgação midiática e na maioria das vezes em questões relacionadas a prisões, invasões, assassinatos e outras questões relacionadas a ilegalidades. Precisamos romper a discussão cansativa e inapropriada, egoísta e centralizada, apolítica e obscurantista. Precisamos dar o salto. Trabalhar a partir do que temos e gerar conhecimento, resistência e lucidez.

(Elisa Costa/2018)

A educação sempre foi para mim o caminho possível, necessário e libertador. No nosso caso temos de lutar com a educação em no mínimo três frentes: dentro de nossas famílias, na sociedade em geral e dentro de nós mesmas. Na prática, tudo é mais difícil e não precisaria ser assim. (Elisabete Martinho/2018).

\section{Participação e mediação: vitórias estáticas.}

Não há como discutir e muito menos fazer de conta que não houve avanços, quanto a participação dos "assim chamados ciganos” na vida política e pública do país.

Um pequeno exemplo foi a presença de Mio Vacite, presidente da União Cigana do Brasil, para o reconhecimento e o avanço do respeito nas áreas da Cultura, pela denominação pejora- 
tiva dos dicionários e seu dia a dia nessas batalhas, impediram o desaparecimento das discussões e debates por direitos em âmbito nacional ${ }^{8}$. Existem outros e outras romani que trabalharam essas questões nas décadas de 80, 90 e 2000. Várias ações pontuais de pequenos grupos e famílias em busca de direitos. Em 2005, Miriam Stanescon representou o Brasil na conquista do "Dia Nacional do Cigano", grupos religiosos e a Pastoral dos Nômades também fazem o papel de garantir direitos e assistências sociais aos ciganos, e o ciganólogo e antropólogo Prof. Dr. Frans Monenn apresentava seus trabalhos e pesquisas sobre o tema já fazendo uma crítica sobre as participações sociais e o Anticiganismo. Outro que soube como poucos retratar a questão "Cigana" no Brasil foi o Prof. Dr. Ático Villas-Boas da Mota. Doutor em Letras pela Universidade de São Paulo (USP) e escritor, ele, muito simples e objetivo como era costume seu, diz numa das muitas entrevistas que deu sobre o tema:

A pátria do povo cigano é a própria alma deles. Já a barraca é o mínimo que eles têm de referência telúrica. ... O território do cigano deveria ser como o de uma embaixada, você não pode invadir. Teria que ser respeitado por todos como domicílio 9 .

E faço a seguinte reflexão:

Nas batalhas de críticas e no enquadramento das caixinhas, precisamos respeitar o trabalho feito, mas precisamos avançar. Somos e precisamos ser mais do que apenas casos referenciais. Não é mais a ótica do outro sobre nós e teremos de romper essa tentativa secular de aculturamento. Disputas por protagonismo e mágoas sem fim, são muito utilizadas nas questões relativas a Rromá (Elisa Costa/2018).

A partir de 2009, dados oficiais governamental como da Pesquisa de Informações Básicas Municipais ${ }^{10}$ (MUNIC) do Instituto Brasileiro de Geografia e Estatística (IBGE) começaram a gerar dados, insuficientes, mas, necessários sobre "os assim chamados ciganos". Nos anos seguintes aparecemos no Cadastro Único (CadÚnico) ${ }^{11}$, do então Ministério do Desenvolvimento Social, e a SEPPIR/PR no comando da Ministra Luíza Bairros ampliou os diálogos de forma a dar em prática agendas nacionais e internacionais. O Ministério Público Federal também começou a olhar de forma mais objetiva para essas questões e a partir de 2010 as coisas ganharam

\footnotetext{
${ }^{8}$ Disponível em: http://www.aba.abant.org.br/files/20190415_5cb4d004ea984.pdf

${ }^{9}$ Disponível em: https://diariodonordeste.verdesmares.com.br/editorias/regiao/a-patria-do-povo-cigano-e-a-propria-alma-deles-1.326652

${ }^{10}$ A pesquisa fornece informações variadas sobre a gestão pública municipal. A periodicidade é anual e sua abrangência geográfica é nacional, com resultados divulgados para Brasil, Grandes Regiões, Unidades da Federação e Municípios.

${ }^{11}$ O Cadastro Único é um instrumento da política socioassistencial para a seleção e a inclusão de famílias de baixa renda em programas federais, sendo usado obrigatoriamente para a concessão dos benefícios do Programa Bolsa Família, da Tarifa Social de Energia Elétrica, do Programa Minha Casa Minha Vida, da Bolsa Verde, entre outros.
} 
um novo formato. O livro de Priscila Paz Godoy intitulado "O povo invisível: os ciganos e a emergência de um direito libertador”, já nos dá na prática essas conquistas de diálogo, participação e controle social.

Poderíamos pensar aqui (no início de 2016) que o pior já havia passado, deixaríamos para trás a invisibilidade da Rromá no Brasil e teríamos enfim uma política de governo em ascendência. Não foi bem assim que aconteceu. Mais uma vez o resguardo de documentação é um entrave para a história dos movimentos sociais. Sendo assim, outro ponto a se levar em consideração é o resguardo da história política da Rromá no Brasil. Mesmo com a nossa preocupação (AMSK/Brasil) em fazer esse trabalho de proteção, compilação de dados e estudo das publicações, com a quebra do Estado de direito ocorrida em 2016, todo esse mecanismo se tornou um enorme desafio.

No Brasil existem vários fenômenos quando se trata da Rromá, em escalas bem definidas. A força midiática do misticismo, o racismo institucional, o racismo coletivo e social por um lado da balança, a falta de formação política, consciência e a aproximação da vida administrativa brasileira, se junta a extrema necessidade de sobreviver, velha técnica conhecida de todos os que pertencem a Rromá. Com isso, o que aconteceu foi um despreparo enorme dos cargos de conselheiros nacionais e estaduais, ampliando as chances de fracasso, advindas de pautas muito mais pessoais do que coletivas, a valorização exacerbada da pobreza e da miséria como identificação dessa etnia ganharam novas formas de perpetuação do estereótipo. O despreparo dos organismos e instituições em lidar com o folclore enraizado gerou e continua gerando várias e contínuas contendas, desnecessárias e que afetam diretamente o andamento do que poderia ser um grande período de avanço em temas de extrema importância como o cumprimento da política de saúde e o chamado estatuto do povo cigano.

Quanto a PORTARIA N ${ }^{\circ}$ 4.384, DE 28 DE DEZEMBRO DE 2018 altera a Portaria de Consolidação $\mathrm{n}^{\circ}$ 2/GM/MS, de 28 de setembro de 2017, para instituir, no âmbito do Sistema Único de Saúde - SUS, a Política Nacional de Atenção Integral à Saúde do Povo Cigano/Romani, caberia uma preocupação ligada ao controle social para o cumprimento da mesma.

Quanto ao "Estatuto do Cigano" caberia o cumprimento da escuta qualificada e a participação efetiva dos sujeitos de direito. Mesmo com algumas reuniões, sessões e outras formas de acolhimento de informação, chegamos à conclusão que o documento permanece frágil, direcionado e com fortes sinais de rromafobia, pois não cumpre uma das principais e maiores solicitações, as da escuta qualificada. Várias cartas, solicitações e tentativas de avanço no texto foram feitas sem grandes avanços. Coube nos buscar ajuda no Ministério Público Federal que, mesmo compreendendo as falhas sobre a questão, não tem conseguido ampliar a escuta qualificada. 
Seguimos sem movimentação, mas extremamente apreensivas e buscando novas formas de explicar o que ainda necessitamos de muito para fazê-lo. Na primeira versão do dito estatuto, PLS 208/2015, a menção de "Situação análoga a cigano" deixou claro o empobrecimento das discussões sobre o tema ${ }^{12}$. Na última versão apresentada, seguem as dificuldades relativas a forma nominal (nomenclatura), o aculturamento e o direcionamento que mantem a "barraca" com a ilusão de liberdade cultural e as questões referidas por "acampamento" e nomadismo como tradicionais e culturais, o que nos faz refletir em especial sobre as formas da manutenção da rromafobia e do anticiganismo ${ }^{13}$.

Continuando no âmbito das discussões internas, várias tentativas, encontros, reuniões e comissões aconteceram ao longo da última década. É fato que temos uma soma enorme de documentos confiáveis, arquivos e demandas visibilizadas, do que tínhamos nos anos anteriores, mas ainda não demos o salto e essas questões estão diretamente ligadas entre si.

1. Não existem dados suficientes para aplicarmos políticas públicas de base; temos o costume de falar que o Brasil se especializou nos números mágicos e aproximados, sem nenhuma base científica. O que já foi produzido não foi aprimorado e nem utilizado.

2. A participação social necessita de objetividade e de conhecimento; preparo por assim dizer, conhecimento dos mecanismos sociais, eis uma lacuna aberta através dos anos e que agora nos cobra caro por isso.

3. A forma de viver e estar do povo romani no Brasil não é unificado e o governo precisa compreender isso: URGENTE.

4. Organismos do governo, ministério público e políticos ainda subsidiam frases como: a moradia tradicional dos ciganos é a barraca ou no Brasil existem aproximadamente de 800 a 1 milhão de ciganos, desrespeitando assim nomenclaturas, fazendo referências a números mágicos e simplesmente reforçando a ideia da residência oficial dos "ciganos" ser a barraca, sendo que esta representa a falta de política social e pública, a condição imposta pela perseguição e pela injustiça social e mantendo os focos de discussão exatamente igual aos séculos anteriores.

\footnotetext{
${ }^{12}$ Disponível em: https://legis.senado.leg.br/sdleg-getter/documento?dm=2920801\&ts=1567534986777\&disposition=inline

${ }^{13}$ Disponível em: https://legis.senado.leg.br/sdleg-getter/documento?dm=7929672\&ts=1567534988173\&disposition=inline
} 
Compreender os espaços, saber que são nossos e com isso construir dignidade e respeito, são ações muito difíceis. Muitos desistem. Os favores são mais atraentes. Então, precisamos lutar dentro e fora da Rromá.

(Sam Cândido/2019)

Pensem comigo: se não temos dados oficiais "quantitativos" - daqueles que provam que atrás dos números existem pessoas, se não nos preocupamos com o incentivo aos estudos, as condições de trabalho, emprego e renda, manteremos fixadas participações de conveniência, as soluções através de vantagens pessoais e familiares e a distância das soluções de fato. Perpetuam- se crenças, fantasias e conveniências. Ganhamos salvadores da pátria e especialistas, assim como políticos que se tornam grandes salvadores e protetores do dia para noite, sem sequer saber a diferença entre a Rromá e os assim chamados ciganos.

Entre 2018 e 2019, criou-se um burburinho quanto aos dados "qualitativos e específicos", somos absolutamente contra. A história no mundo nos recorda, através dos tempos, que a rromafobia, a segregação e o extermínio sempre foram práticas que contaram com o amplo apoio dessas condições. Vários Rromá no mundo têm se manifestado sobre o assunto, especialmente com a onda de violência da extrema direita, crescente nos países da América Latina e Europa.

Quando participamos de espaços sociais no município em que moramos, temos condição de analisar de perto os avanços. Ajudar a fazer uma agenda que observe a saúde, a condição física, a pobreza e a educação. Por vezes o que o governo quer, é apenas demonstrar serviço, por isso qualquer pessoa serve. Não pode ser assim, precisamos que essa responsabilidade seja do município, da comunidade e que fale de todos. Isso não é favor. É direito.

(Leda Cruz/2018)

Usar dados quantitativos pode e deve ser um mecanismo de aplicação da política, mas também, na condição da atual política brasileira, pode ser uma forma de manter contida e controlada, como política de governo, a realidade da Rromá no brasil. Não há consciência e por vezes conhecimento da política em relação a maioria dos envolvidos nas questões de participação social no Brasil quanto ao tema.

Cada vez mais precisamos estudar, criar esse mecanismo, investir nessa cumplicidade. Toleramos por muitos anos as informações erradas, por ser cômodo. Hoje não queremos mais. Falam por nós, sobre nós. São falas que aumentam o medo, a indiferença e a superstição. Falam de Esmeraldas e Carmens, não falam de nós.

(Lucimara Cavalcante/2018, AMSK/Brasil)

Hoje, podemos contabilizar que no quesito controle social, temos aproximadamente 12 ou 15 romani que o fazem em todo o país, com excelência de conhecimento. O imediatismo torna 
os apelos midiáticos, sociais e políticos fora dos trilhos. Apenas poucas entidades pensam nas construções de direitos como participação, controle e exercício da cidadania e desses, menos ainda o fazem de associações politicamente constituídas. Ao contrário do que se necessita, não existem diálogos que aprecie e coloque na prática de alguma forma, a expansão da discussão, a ampliação de reservas de recursos para a educação e a busca de uma ação direta na aplicação das leis e dos marcos legais.

Faço o que posso, mas, até hoje, nos seguem nos supermercados. Esse é o preconceito diário, cotidiano. Não posso fazer de conta que é normal ou que é comum. Como lutar contra. Existem situações que nos impedem de reagir. Nos adoece.

(Marcia Castilho/2018)

A lógica do necessitar, dialogar, construir e aplicar não se estabelece na prática do cotidiano da Rromá no Brasil, quando se faz necessária a presença do estado para campanhas nacionais. Quando na publicação parcial do meu trabalho em 2017 em as "Mulheres Romani (ciganas): Rostos e Identidades", durante as pesquisas de campo, fiquei bastante preocupada com os resultados. A condição e o uso das mulheres de etnia romani nesses locais de fala são extremamente prejudiciais e estereotipados. A mídia tem se encarregado de boa parte desses equívocos, mas o poder público não fica atrás. A exposição das mulheres como referência cultural, coloca as vestimentas como fator primordial de identificação de uma parcela da população e de um dos braços étnicos em especial, os calon.

A seguir falas de romani que rompem o silêncio em reuniões promovidas pela AMSK/Brasil e na participação social em reuniões governamentais:

Romper os caminhos iniciais não é tão difícil, o mais difícil é lutar contra a vaidade e a ignorância. Somos bem vistos para alegrar a corte real, ainda é assim, mas não nos querem nos serviços públicos, nas universidades, no dia a dia. Somos reais. Existimos.

(Anne Kellen/2018, Lovara)

O que cansa é a participação midiática. Aqui tem no mínimo dois exemplos: Goiás e Mato Grosso do Sul. Os recursos nunca chegam quando o assunto é a Rromá. Não vem. Fazemos número, como nas vitrines, tiramos fotos, só isso. Daí apresentamos os projetos, como bolsa de estudos, cursos formativos, publicação de livros ou mesmo no campo cultural, não chega. Viramos projetos de alguém, do governo ou mesmo do Ministério Público, mas, não comandamos o nosso próprio show. Muitas vezes dividimos os espaços e as cadeiras com "ciganos espirituais" e assim vamos perdendo cada vez mais espaços, porque não somos esquecidos, somos substituídos pela fantasia midiática dos governos em busca dos votos.

(Pedro Nicolith e Alexsandro Castilho/2018, Matchuaia e Kaldarash) 
Mediar conflito onde já entramos perdendo porque somos ciganos. É uma realidade, por isso me preocupa quando o governo diz que quer nos ajudar. Procuramos, contamos o que acontece, tiram fotos e depois volta tudo ao normal. Nada é feito. A solução é construir nossas agendas e convidá-los, quem sabe a ficha cai. Uma "cigana é agredida dentro do rancho e a delegada diz que é cultural, o político diz que é cultural, que raio de cultura da violência é essa, deixada a nossa própria sorte em pleno século 21 ?

(Sonia Reis/2018, Lovara)

Somos chamados a colaborar, dia após dia. Eu faço isso. Quem paga as minhas contas? Porque as questões da Rromá são despidas das questões lógicas? O anonimato rende mais, é isso que vemos. Entramos para a universidade, rompemos ciclos, ampliamos horizontes e não conseguimos sair da rua de casa. A quem interessa o ciclo de ignorância e de pobreza? A mim não é, tenho certeza disso. Outra coisa é quando falamos da cultura, são tantos absurdos que se vê. Estamos perdendo na música, na arte e na dança. Cotidianamente. Os processos duram anos até que consigamos romper e mesmo assim não conseguimos estabilizar. O que acontece é o abandono. Voltamos a viver nossa cultura de fato da porta de casa para dentro, o resto é folclore que se vê, internet é terra de ninguém.

(José Ruiter/2018, Lovara)

São batalhas desumanas e vamos ter de nos preocupar com elas. Daqui a alguns anos, seremos culpadas por não sermos analfabetas, basta saber o que vão nos questionar. Para eles somos as meninas boazinhas e bobinhas. Não há respeito, existe uso.

(Marcia Vasconcelos/2018, AMSK/Brasil)

Existe o medo e ele ainda é grande. Ficamos à própria sorte por anos e mesmo quando conseguimos formar os nosso, o caso da minha sobrinha, que se formou em odontologia, ela não conseguia trabalhar. O prefeito a empregou na prefeitura da cidade, os moradores daqui é que não iam, tinham medo. Ela desistiu.

(Valdir Apolinário/2017, Calon)

Não há um dia sequer que a gente não luta contra a invisibilidade dos nossos problemas. Mas as vezes o gestor acha de fazer a coisa do jeito dele, e daí vale qualquer coisa. Não tem firmeza, promete hoje e descumpre amanhã. Quando dá certo é porque lutamos sozinhos.

(Alexsandro Castilho/2018) 
Cabe relembrar que a participação qualificada Conselhos Nacionais de participação social, trouxe a Resolução no $181 / 2016^{14}$ do CONANDA - Conselho Nacional dos Direitos da Criança e do Adolescente, e o primeiro informativo do caderno do Ministério do Desenvolvimento Social sobre o atendimento qualificado ao povo romani/ciganos no Brasil.

Importante destacar que a Oficina "Sistema Único da Assistência Social - SUAS e o atendimento a Povos Ciganos”, e a Política de Saúde no Brasil e na América Latina. Todos, fruto de conversas, escutas qualificadas, diálogo e pesquisa.

Duas ações que contaram com escuta e participação social capacitada a transmitir, discutir e dialogar. Nas duas questões relatadas acima, a participação local, ou seja, do município e do estado são fundamentais para a aplicação dos direitos, respeitando os territórios e sua ampla ververipen - diversidade.

\section{Conclusão}

As falas acima citadas são de reuniões da AMSK/Brasil e eventos nos quais participei e/ou proporcionei entre 2016 e 2018 . O cenário político brasileiro recheado de analfabetismo político, obscurantismo religioso e a Rromá no meio, exatamente no meio, me fez, contando com as possibilidades que a AMSK/Brasil concede a seus membros, parceiras e parceiros, ampliar visitas, construir agendas e realizar pesquisas e reuniões por meio eletrônico e telefônico.

É possível avançar, é necessário avançar e compor espaços de fala, de voto e de ação, mas é preciso respeitar as formas com que a Rromá se organiza no país. Equidade. Entretanto é de extrema importância afirmar que o controle social é construído aos poucos e de forma ainda frágil pela Rromá no Brasil. Conhecimento precisa ser encarado como direito e não somente como poder. Educação é uma das palavras chaves e quando digo Rromá, digo todos.

Não adianta dar números de participações desqualificadas, discursos empobrecidos pela baixa ou quase nenhuma condição de participação pública e social. Várias ditas conquistas e vitórias, espalhadas por facebook ou WhatsApp, contam de forma rápida e sem nenhuma clareza objetiva sobre questões nacionais. É apenas a foto.

Ao analisar as agendas de reunião a fim de avançarmos para 2019 com objetividade, tínhamos uma incógnita e um temor, infelizmente esse se consolidou com o término de vários espaços de decisão e escuta. Não há investimento algum nas agendas de discussão e acreditamos

\footnotetext{
${ }^{14}$ Resolução no 181 , de 10 de novembro de 2016, dispõe sobre os parâmetros para interpretação dos direitos e adequação dos serviços relacionados ao atendimento de Crianças e Adolescentes pertencentes a Povos e Comunidades Tradicionais no Brasil.
} 
que em 2020 o cenário fique pior para a participação social de maneira geral e como um todo. Sem o mínimo de recursos não se constrói alternativas e nem se estabelece estratégias.

Quem querem nessas participações? Nós ou os que pensam por nós? Nos chamam para falar sobre as violências que sofremos e são noticiadas na mídia. Não querem saber o que pensamos e nem se de fato essas situações existem. Não é sobre nós, é sobre o que acham que somos e assim precisam de nós para reafirmarem condutas e estereótipos já consolidados. Não querem saber da nossa realidade, distinta, ampla, étnica e social. Querem a mística, o folclore, a violência e a miséria. Somos mais que isso.

(Natália Jorge e Maria Suveta/2018)

Entre o cotidiano de um preconceito já enraizado e étnico, permanente e coletivo, precisamos caminhar para além da dependência de um estado nação que não reconhece os valores e as necessidades da participação e do controle social. Contrapor a mídia que nos retira a identidade e nos joga dentro de um balaio de informações estereotipadas, romper com as dependências formais e buscar na construção do entendimento, saídas sociais que viabilizem e combatam de frente o maciço jogo do empobrecimento, do aculturamento e da globalização, como nova forma de exclusão social.

Todas as saídas possíveis, passam pela coletividade, participação, conhecimento e controle social. Se nos mantivermos afastados dessa discussão, outros o farão por nós, se nos encolhermos ante os acontecimentos, seremos tragados para reviver novas formas do Porrajmos $^{15}$. É disso que se trata, é por isso que tenho dedicado muito tempo aos (re)encontros.

\footnotetext{
${ }^{15}$ Expressão em romanês, a grande devoração, utilizada pelos Rroma para nomear a destruição provocada pelo
} holocausto. 


\section{Bibliografia}

Cavalcante, L. V. (2019). História, identidade e dinâmicas territoriais do povo rom no Brasil. Dissertação de mestrado, Universidade de Brasília, Brasília, Brasil.

Constituição da República Federativa do Brasil. (1988). Brasília: Senado Federal.

Decreto-lei no 6.040/2007 de 7 de fevereiro. Presidência da República do Brasil. Ministério de Estado do Meio Ambiente. Ministério de Estado do Desenvolvimento Social e Combate à Fome. Acedido em: 12 outubro 2019, em: http://www.planalto.gov.br/ccivil_03/_Ato2007-2010/2007/Decreto/D6040.htm

Decreto n ${ }^{\circ}$ 10.088/2020 de 5 de novembro. Presidência da República do Brasil. Acedido em: 5 julho 2020, em: http://www.planalto.gov.br/ccivil_03/_Ato20192022/2019/Decreto/D10088.htm

Godoy, P. P. (2016). A racialização dos(as) ciganos(as) e a experiência Calon de Belo Horizonte como sujeitos coletivos de um projeto histórico de liberdade. Belo Horizonte: Editora D'Plácido. ISBN 978-85-84252-17-6.

Instituto Brasileiro de Geografia e Estatística. (2009). Pesquisa de Informações Básicas Municipais - MUNIC [CD-ROM]. Brasília: IBGE.

Ministério de Estado de Desenvolvimento Social do Brasil. Secretaria Nacional de Desenvolvimento Social - SNAS/MDS. (2017). Informativo atendimento a povos ciganos no SUAS. Acedido em: 21 outubro 2019, em:

https://www.mds.gov.br/webarquivos/publicacao/assistencia_social/informe/Povos_Cigan os.pdf

Ministério de Estado da Saúde do Brasil. (2016). Subsídios para o cuidado à saúde do povo cigano. Brasília: Ministério da Saúde. ISBN 978-85-334-2437-1. Acedido em: 20 outubro 2019, em: http://bvsms.saude.gov.br/bvs/publicacoes/subsidios_cuidado_saude_povo_cigano.pdf

Moonen, F. (2013). Anticiganismo e políticas ciganas na Europa e no Brasil. Revisão 2013. Publicação online em: https://www.amsk.org.br/estudosepesquisa.html.

Mota, Á.V-B da. (1986). Os ciganos: uma minoria discriminada. Rio de Janeiro: Revista Brasileira de Política Internacional, ano XXIX, vol. 115/116, 21-46.

---- 1984. “Os ciganos do Brasil”, Correio da Unesco, ano 12, 32-34.

Projeto de Lei do Senado no 248 , de 2015. Congresso Nacional do Brasil. Em: https://legis.senado.leg.br/sdleggetter/documento?dm=2920801\&ts $=1567534986777 \&$ disposition=inline

Portaria n ${ }^{\circ}$ 4.384/2018 de 28 de dezembro. Ministério de Estado da Saúde do Brasil. Acedido em: 21 outubro 2019, em: https://bvsms.saude.gov.br/bvs/saudelegis/gm/2018/prt4384_31_12_2018.html

Resolução nº 181/2016 de 16 de novembro. Conselho Nacional dos Direitos da Criança e Adolescente-CONANDA. Acedido em: 21 outubro 2020, em: https://www.direitosdacrianca.gov.br/conanda/resolucoes/resolucao-no-181-de-10-denovembro-de-2016 
Santos, B. S. (2003). Reconhecer para libertar: os caminhos do cosmopolitismo multicultural. Em: Coleção Reinventar a emancipação social, vol. 3. Civilização Brasileira, Rio de Janeiro. ISBN 978-85-20006-17-7.

Vasconcelos, M. e Costa, E. (2015). Datas de celebração e luta pelos direitos dos Povos Romani (Ciganos): 8 de Abril Dia Internacional dos Romani (Ciganos), 24 de Maio Dia Nacional do Cigano, 2 de Agosto Dia Internacional em Memória do Holocausto Cigano. $1^{a}$ edição. Brasília: AMSK/Brasil. ISBN 978-85-67708-02-7. Acedido em: 5 julho 2020, em:

https://www.amsk.org.br/imagem/publicacao/Publicacao3_AMSK_2015_DatasCelebracao.pd $\underline{\mathrm{f}}$ 



\title{
Capítulo 10. \\ Desafios e conquistas à visibilidade do povo romani nas políticas sociais brasileiras
}

\section{LUCIMARA CAVALCANTE ${ }^{1}$}

Fundadora da Associação Internacional Maylê Sara Kalí (AMSK/Brasil). Mestrado Profissional em Sustentabilidade junto a Povos e Territórios Tradicionais, do Programa de Pós-Graduação Profissional em Desenvolvimento Sustentável da Universidade de Brasília (MESPT/UnB).

amsk.lucimara@gmail.com

Resumo: O racismo social é um elemento fortemente presente na estruturação e organização da sociedade brasileira, e estabelece barreiras para que determinados grupos raciais e étnicos acessem direitos, bens e serviços. O Povo Romani no Brasil sofre de forma severa os efeitos do racismo que estabelece as bases para atos de discriminação racial e étnica que se manifestam em diferentes esferas da vida. A geração de dados sobre a identidade cultural e dinâmicas territoriais dos grupos étnicos torna-se importante instrumento para a elaboração e implantação de políticas públicas setoriais e de direitos adequadas as condições de vida desta população étnica brasileira.

Palavras chave: Povo Romani, Discriminação Étnica, Políticas Sociais.

\begin{abstract}
The social racism is a very strong element that is present on the structurazion and organisation on the Brazilian society and establish barriers so we can determine to specific racial and ethnical groups, rights, goods and services. Romani people in Brazil suffer from severe effects of racism that establish the basis for acts of racism and ethnical discrimination that appears on different times of life. The generation of data about cultural identity and territorial dynamics of the ethnical groups become an important instrument for the elaboration and implementation of setorial public politics and on adequated rights of livelihood of this ethnical brazilian population.
\end{abstract}

Keywords: Romani people, Ethnic discrimination, Social Policies

\footnotetext{
${ }^{1}$ Lucimara Cavalcante, Descendente da etnia Kaldarash; fundadora da Associação Internacional Maylê Sara Kalí (AMSK/Brasil); coordenadora do projeto Kalinka contemplado com o Prêmio Nacional em Educação de Direitos Humanos 2014; professora de danças romani; defensora dos direitos humanos do Povo Rom do Brasil; representante da AMSK/Brasil no Conselho Nacional dos Direitos da Mulher; discente do Mestrado Profissional em Sustentabilidade Junto a Povos e Terras Tradicionais da Universidade de Brasília (MESPT/UnB).
} 


\section{Introdução}

O Povo Romani - os pejorativamente chamados "ciganos" - no Brasil possui história e merece reconhecimento. Degredados de Portugal no século XVI para as terras de além-mar, as colônias da África e América, sob a pena de ser "cigano" enfrentaram todas as formas de proibição a manutenção de sua cultura, mas, resistiram a todas as perseguições impostas pelo império português estabelecidas por Cartas de Leis, Decretos, Alvarás, Cartas Régias, Leis e Decisões imperiais (Costa, 1997).

De prisioneiros, escravos a donos de terras permaneceram no território e contribuíram para formação do Estado-nação brasileiro. Embora objeto de preconceitos, discriminação e racismo dada a sua diferença cultural, nosso povo encontrou meios de sobrevivência para estabelecer sua territorialidade (Cavalcante, L. V., 2019, p. 17).

Nos dias atuais, no Brasil o Povo Romani é composto por 8 etnias: Kaldarash, Lovara, Matchuaia, Boyasha, Rudari, Horaranô, Calon e Sinti. Cada uma com especificidades próprias que se distinguem pela língua, costumes, atividades econômicas, moradia, vestimentas, artesanato, religião e crenças. E estão identificadas a sua presença em todas as 27 unidades federativas do Brasil.

Descendo de família pertencente à etnia Kaldarash que chegaram ao Brasil no final do século XVIII trazendo em sua bagagem o patrimônio cultural imaterial e material - idioma romanês, a música, a dança, o artesanato do tacho de cobre, da ourivesaria e cutelaria. E como muitos outros advindos de países da Europa - Itália, França, Espanha, Grécia - também carregavam em suas bagagens o estigma do preconceito, da discriminação e do racismo.

Nossa identidade cultural e dinâmicas territoriais ainda são pouco conhecidas pela sociedade brasileira, corroborado pela inexistência de informação sobre a nossa história, modo de vida, tradições e costumes. E sem informação, se fortalece a prevalência do preconceito, da discriminação e do racismo coletivo ao longo dos tempos. Conforme argumenta a romani sinti Soria, o olhar romà foi configurado por uma história de racismo, marginalização e associação da cultura do grupo étnico a uma série de imagens petrificadas e negativas, que se formaram ao longo da diáspora romani (Soria, 2015, p. 25).

Diante do fato tornou-se imprescindível a nossa dedicação ao levantamento, sistematização e ampla divulgação de informações sobre as especificidades culturais do Povo Romani - ciganos - do Brasil. Em especial sobre as condições de vida e os obstáculos enfrentados ao acesso a serviços públicos ofertados.

Nessas circunstâncias, minha família instituiu no ano de 2009 a Associação Internacional Maylê Sara Kalí (AMSK), organização da sociedade civil, sem fins econômicos, fundada por 
mulheres que vislumbram um futuro de conhecimento, uma construção ativa e integrada do conhecimento para que as futuras gerações sejam livres da discriminação e do racismo.

Nosso trabalho consiste na incidência política junto aos organismos governamentais do poder executivo, judiciário e legislativo no âmbito federal, estadual, municipal e Distrito Federal, em defesa dos direitos humanos da população brasileira pertencente ao Povo Romani.

Com principal demanda ao cumprimento da Convenção no 169 da Organização Internacional do Trabalho - OIT, promulgada no Brasil pelo Decreto $\mathrm{n}^{\circ} 5.051^{2}$, de 19 de abril de 2004, consolidada no Decreto $\mathrm{n}^{\mathrm{o}}$ 10.088, de 5 de novembro de 2019, dispõe que "os governos deverão assumir a responsabilidade de desenvolver, com a participação dos povos interessados, uma ação coordenada e sistemática com vistas a proteger os direitos desses povos e a garantir o respeito pela sua integridade". Aos povos e comunidades tradicionais deve ser assegurado " $o$ controle de suas próprias instituições e formas de vida e seu desenvolvimento econômico, e manter e fortalecer suas entidades, línguas e religiões dentro do âmbito dos Estados onde moram".

Em 2019, a AMSK completou 10 anos. As ações de advocacy - argumentação e defesa de causas e direitos - evidenciam a importância da participação social na gestão de políticas públicas setoriais e de direitos para garantir o atendimento com equidade nos serviços públicos. Os direitos fundamentais à população romani - cigana - assegurados na Constituição da República Federativa do Brasil de 1988 a possibilidade de ter uma vida digna, livre e igualitária.

Embora engajadas nos espaços de discussão e elaboração de políticas públicas há uma eficiência limitada do governo brasileiro no atendimento as nossas demandas pelo respeito a nossa etnicidade e ao direito a dignidade da pessoa humana, os direitos humanos. Mesmo assim permanecemos atuantes na participação social para afirmar que as/os romani - ciganas/ciganos existem no país e buscam vencer os obstáculos ao acesso a saúde, assistência social, educação, trabalho, previdência social, registro civil, habitação condigna, saneamento básico, segurança pública.

Atualmente, a AMSK é membro do Conselho Nacional dos Direitos da Criança e do Adolescente (CONANDA), do Conselho Nacional dos Direitos da Mulher (CNDM) e do Conselho Nacional de Povos e Comunidades Tradicionais (CNPCT) - órgãos colegiados de composição paritária, organizações da sociedade civil e governo, de caráter deliberativo e consultivo. Em

\footnotetext{
${ }^{2}$ Todas as convenções e recomendações da Organização Internacional do Trabalho - OIT, aprovadas pelo Congresso Nacional, promulgadas por ato do Poder Executivo Federal foram consolidadas no Decreto $\mathrm{n}^{\mathrm{o}} 10.088$, de 5 de novembro de 2019.
} 
anos anteriores compôs o Conselho Nacional de Assistência Social (CNAS) - 2016 a 2018 -, e o Conselho Nacional de Promoção da Igualdade Racial (CNPIR) - 2015 a 2017.

Importante salientar que nesses espaços de discussão das políticas setoriais e de direitos, a AMSK não se apresenta como a representante do Povo Romani do Brasil, mas, sim, como partícipes da sociedade civil organizada para o exercício democrático no controle social do planejamento, implantação e execução de ações e programas governamentais.

As reuniões dos Conselhos oportunizam a apresentação de informações sobre a realidade de vida das famílias romani - cigana - dispersas nas unidades federativas do país, com diferentes etnias, cada uma com sua especificidade cultural.

Nessas ocasiões, a AMSK demanda e defende a visibilidade na aplicação de programas e ações das políticas públicas dessa população étnica e das demais pertencentes a povos e comunidades tradicionais - indígenas, quilombolas, matriz africana, geraizeiros, ribeirinhos, pescadores artesanais, castanheiras, marisqueiras, entre outros. Pois, no Brasil há uma imensa diversidade sociocultural caracterizadas pelas etnicidades, as diferentes formas de organização social e expressões culturais.

Assim, neste Seminário Internacional Ciganos em Portugal, Espanha e Brasil apresentamos as conquistas provenientes das ações de advocacy - argumentação e defesa de causas $e$ direitos - da AMSK junto ao governo brasileiro e os desafios a serem superados na aplicação das políticas sociais para a população brasileira pertencente ao Povo Romani.

\section{Da invisibilidade ao reconhecimento identitário cultural do Povo Romani no Brasil.}

O Povo Romani é marcado pelo estigma secular do preconceito, da discriminação e do racismo da sociedade e classe dominante europeia, e, depois, brasileira. A xenofobia e o fascismo criam estereótipos contra pessoas que têm opiniões, atitudes, ideologia e crenças religiosas diferentes da maioria da população.

Assim, devido à intensidade com que os estereótipos são difundidos, estes se tornam de difícil remoção e encontram-se presentes, inclusive, em fontes de fácil acesso, como os dicionários (Soria, 2008: 20).

A antropóloga Jamilly Cunha (2015) mostrou que esses preconceitos estão profundamente enraizados na nossa sociedade. Segundo essa autora:

Mais espantoso é perceber a grandeza do problema, esses estigmas não estão apenas no senso comum. Um exemplo são as definições encontradas em alguns dicionários, inclusive, os mais renomados. Vejamos o caso de um dicionário de Língua Portuguesa bastante reconhecido e utilizado: o verbete utilizado para os ciganos é "I. Indivíduo de um povo nômade, provavelmente originário 
da Índia e emigrado em grande parte para a Europa Central, de onde se disseminou povo esse que tem um código ético próprio e se dedica à música, vive de artesanato, de ler a sorte barganhar cavalos, etc. 2. Fig. Indivíduo boêmio, erradio, de vida incerta. 3. Fig. Indivíduo trapaceiro, trampolineiro, velhaco. 4. Fig. Vendedor ambulante. 5. Fig. Designação de um dos carneiros de guia. Adj. 6. Errante, nômade. 7. Ladino; astuto; trapaceiro”" (grifos nosso)...

(...) Os filmes, as músicas, as novelas e a própria literatura reforçam e reproduzem esse quadro, onde mulheres ciganas aparecem sempre como sensuais e por isso imorais e os homens são apresentados como violentos e trapaceiros. Na prática os ciganos são, tudo aquilo que nós, "os outros", não devemos ser. Conforme se ver é uma "perfeita relação de alteridade", os brasileiros ou qualquer outro grupo social se colocam em total oposição diante do "mundo cigano". E, portanto, o que se percebe no senso comum, é a ideia de uma "vida cigana" dotada de uma liberdade exacerbada, uma situação de imoralidade constante e uma impureza que parece ser contagiosa, por isso, a população sempre agiu de modo que não houvesse qualquer contato (Cunha, 2015, pp. 16 e 30).

Os preconceitos denunciados por Cunha (2015) também estão presentes no dicionário da língua portuguesa Priberam que traz como definição para a palavra "cigano":

[Informal] que ou aquele que tem vida errante;

[Informal] que ou aquele que tem arte e graça de captar as vontades;

[Informal] que ou quem age com astúcia para enganar ou burlar alguém. = BURLÃO, IMPOS-

TOR, TRAPACEIRO, VELHACO;

[Pejorativo] que ou aquele que é excessivamente agarrado ao dinheiro. = AVARENTO, SOVINA.

De forma semelhante, o dicionário Aurélio de português online, em sua página na internet, apresenta como definição de "cigano":

1 - Viver ou comportar-se como cigano.

2 - Levar vida errante.

3 - Enganar alguém com astúcia.

4-CIGANEAR. ${ }^{3}$

Nesse contexto, cremos que o dicionário foi mais um instrumento estratégico da sociedade e classe dominante para a promoção frequente da exclusão social do Povo Romani. Pelo significado pejorativo da palavra "cigano" foram marginalizados e impedidos de exercer livremente seus direitos de cidadãs e cidadãos brasileiros.

\footnotetext{
${ }^{3}$ https://dicionariodoaurelio.com/cigano
} 
As seguintes questões devem ser pautadas para reflexão: (i) Por quê ao longo dos tempos se mantém nos dicionários da língua portuguesa a mesma definição pejorativa da palavra "cigano"?; (ii) Como as crianças, jovens e adultos romani ingressos na educação escolar enfrentam essas definições descritas no dicionário em ambiente escolar?; (iii) Quais os desafios das/dos brasileiras/os romani - ciganas/ciganos - em efetivar ação afirmativa para eliminação do preconceito, discriminação, racismo e xenofobia descritos no dicionário da língua portuguesa?

Nós romani - ciganas/ciganos - ingressos nesta trajetória acadêmica temos como desafio mudar o ciclo de o desconhecimento da sociedade em geral sobre a nossa identidade cultural. Pensemos que ainda hoje, as nossas crianças e jovens ingressos no ensino fundamental e médio são orientadas por seus responsáveis a omitirem seu pertencimento étnico no ambiente escolar. Atitude que visa a sua proteção física e psicoemocional diante do iminente racismo estrutural.

No Brasil, os profissionais da educação não têm em sua trajetória de formação qualquer informação sobre a existência do Povo Romani no país desde o século XVI. De escravos, prisioneiros, donos de terras, comandantes e integrantes das armadas imperial portuguesa (Costa, 1997). Nossa história de a contribuição no processo organizativo do Estado-nação brasileiro não consta nos livros didáticos-pedagógicos do país. O que cremos ter sido mais uma estratégia da classe dominante para permanência do racismo contra os romani - ciganos.

Nesse cenário, a AMSK tem como desafios: (i) sensibilizar as famílias romani - cigana sobre o direito de suas filhas e filhos permanecerem na trajetória escolar sem constrangimento ao pertencimento étnico; e (ii) romper com o ciclo da falta de informação no sistema de ensino brasileiro sobre a história, as especificidades étnicas e culturais do Povo Romani.

Embora a Constituição da República Federativa do Brasil de 1988, Art. 5, I, Art. 210, Art. 206, I, $\S 1^{\circ}$ do Art. 242, Art. 215 e Art. 216, que asseguram o direito à igualdade de condições de vida e de cidadania, assim como garantem igual direito às histórias e culturas que compõem a nação brasileira, além do direito de acesso às diferentes fontes da cultura nacional a todos brasileiros. Ainda são tímidas as ações desenvolvidas pelo poder executivo na esfera federal, estadual, municipal e do Distrito Federal para o atendimento das nossas demandas e implementação de políticas na área de educação, saúde, assistência social, trabalho, segurança pública, moradia condigna e ordenamento territorial.

A Declaração e Programa de Ação adotados na III Conferência Mundial contra o Racismo, a Discriminação Racial, a Xenofobia e Formas Correlatas de Intolerância, realizada pela Organização das Nações Unidas (ONU), entre 31 de agosto a 8 de setembro de 2001, na cidade de Durban, África do Sul, em seu artigo 68, o documento afirma: 
68. Reconhecemos com grande preocupação as manifestações de racismo, discriminação racial, xenofobia e intolerância correlata em curso, incluindo a violência contra os Roma, Ciganos, Sinti e Nômades; e reconhecemos a necessidade de se desenvolverem políticas eficazes e mecanismos de implementação para o pleno alcance da igualdade.

Nessa III Conferência, além de visibilizar as demandas dos indígenas e afrodescentes, também destacou o reconhecimento dos romani - ciganos - como vítimas de racismo, discriminação racial, xenofobia e intolerância correlata.

O governo brasileiro, na aplicação das recomendações da ONU, assegurou e garantiu as discussões sobre as demandas do Povo Romani no conjunto de atribuições dadas à então Secretaria Especial de Políticas de Promoção da Igualdade Racial (SEPPIR) da Presidência da República, criada pela Lei $\mathrm{n}^{\circ} 10.678$, de 23 de maio de 2003, com o objetivo de promover a igualdade e a proteção de grupos raciais e étnicos afetados por discriminação e demais formas de intolerância, com ênfase na população negra.

No âmbito das funções políticas desenvolvidas pela SEPPIR, apesar de realçar o processo histórico secular marcado pela escravidão dos negros, consta, em suas ações programáticas, a promoção da garantia de espaços e investimentos que assegurem proteção ao Povo Romani ciganos - do país contra qualquer forma de violência e discriminação. Assim, as nossas reivindicações de o reconhecimento da nossa identidade e o respeito a nossa cultura passaram a compor o rol de políticas compensatórias e das medidas elaboradas e executadas pela SEPPIR contra todas as formas de discriminação, racismo e xenofobia.

A promulgação do Decreto Presidencial de 25 de maio de 2006 que institui o Dia Nacional do Cigano, a ser comemorado no dia 24 de maio de cada ano, é o marco histórico ao reconhecimento da cultura do Povo Romani no Brasil. O artigo $2^{\circ}$ desse Decreto estabelece que As Secretarias Especiais de Políticas de Promoção da Igualdade Racial e dos Direitos Humanos da Presidência da República apoiarão as medidas a serem adotadas para comemoração do Dia Nacional do Cigano.

Esse marco legal promoveu a participação das/dos romani - ciganas/ciganos - em reuniões técnicas e grupos de trabalho interministeriais com a finalidade de coleta de dados e informações sobre a demografia, as especificidades do modo de vida, valores e saberes dessa população étnica brasileira.

Com a promulgação do Decreto n ${ }^{\circ} 6.040$, de 7 de fevereiro de 2007, institui a Política Nacional de Desenvolvimento Sustentável dos Povos e Comunidades Tradicionais, o governo brasileiro reconhece formalmente, pela primeira vez na história do país, a existência formal de 
todas as chamadas populações "tradicionais" do Brasil. Nesse sentido, a autodeterminação identitária cultural do Povo Romani é fortalecida com ênfase no reconhecimento a sua existência em território do Estado-nação brasileiro.

Nesse processo a Secretaria Especial de Políticas de Promoção da Igualdade Racial (SEPPIR) e a Secretaria Especial de Direitos Humanos (SDH) oportunizavam aos membros pertencentes a povos e comunidades tradicionais do país um canal da Ouvidoria Nacional para denúncias dos casos de enfrentamento ao racismo e violação dos direitos.

Em face de as crescentes denúncias por parte dos romani - ciganos - sobre os casos de enfrentamento ao racismo estrutural em diferentes regiões do país, em 2012 a AMSK em conjunto com representações comunitárias encaminham o assunto para a ciência e providências do Ministério Público Federal (MPF).

Nesse processo a Procuradoria Federal dos Direitos do Cidadão do Ministério Público Federal (PFDC/MPF) efetivou várias ações junto aos organismos do poder executivo federal, das quais se destaca a audiência pública realizada no dia 12 de dezembro de 2012, em parceria com a Comissão de Direitos Humanos e Legislação Participativa do Senado Federal.

Momento que consideramos histórico, pois, presentes todas as representações governamentais do poder executivo federal assumiram o compromisso de atendimento às demandas da população romani - cigana -, em especial ao respeito a cultura, o acesso e atendimento com equidade nos serviços públicos ofertados, o direito de residência nos municípios, a garantia dos direitos humanos às populações com moradia em casas, apartamentos, taperas, tendas, e outras habitações.

Nesse sentido, a então Ministra Chefe de Estado da Secretaria Especial de Políticas de Promoção da Igualdade Racial (SEPPIR), Luiza Helena de Bairros, efetivou a pasta de trabalho política interministerial para a elaboração de ações afirmativas ao Povo Romani no Brasil. O objetivo era eliminar desigualdades historicamente acumuladas e combater os efeitos acumulados em virtude das discriminações ocorridas no passado. As agendas de trabalhos promoveram a participação da AMSK e de representações comunitárias romani - ciganas.

O Grupo de Trabalho Interministerial (GTI) sob a coordenação da SEPPIR, composto por representantes governamentais do Ministério da Educação, Ministério da Saúde, Ministério da Cultura, Secretaria Nacional de Economia Solidária do Ministério do Trabalho e Emprego, Secretaria Especial dos Direitos Humanos da Presidência da República, e da Ouvidoria Nacional da Presidência da República planejou e realizou ação conjunta para a celebração do Dia Nacional do Cigano. 
A SEPPIR, nos dias 20 a 24 de maio de 2013, coordenou a organização e realização do evento Brasil Cigano: Primeira Semana Nacional dos Povos Ciganos ${ }^{4}$, em parceria com a AMSK. O acontecimento reuniu em Brasília, Distrito Federal, cerca de 300 romani - ciganas/ciganos - oriundos de 19 unidades federativas para um diálogo com as representações governamentais do poder executivo, judiciário e legislativo federal e do Governo do Distrito Federal. Momento histórico no país em que o governo brasileiro, pela primeira vez ao longo dos séculos, promove a participação de crianças, jovens, adultos e idosos pertencentes as diferentes etnias, a fim de compartilharem seus conhecimentos, necessidades e receios.

Como resultado do evento ações governamentais foram efetivadas nas seguintes áreas:

\section{Educação}

Em atendimento as propostas dos participantes romani - ciganas/ciganos -, na Oficina sobre Diversidade na Educação e os Povos Ciganos, a Secretaria de Educação Continuada, Alfabetização, Diversidade e Inclusão do Ministério da Educação (SECADI/MEC) instituiu pela Portaria $\mathrm{n}^{\circ}$ 10, de 28 de fevereiro de 2014, o Grupo de Trabalho para acompanhar a implementação da Resolução CNE/CEB ${ }^{5} n^{o}$ 03/2012 que estabelece diretrizes para o atendimento de educação escolar à populações em situação de itinerância.

O Grupo de Trabalho composto por representações étnicas romani, AMSK e do governo federal teve como objetivo geral elaborar subsídios para implantação da Resolução nos sistemas de ensino dos estados, municípios e Distrito Federal. Os resultados publicados na cartilha $\mathrm{Ci}$ ganos - Documento orientador para o Sistema de Ensino ${ }^{6}$, com o lançamento em evento de celebração ao Dia Nacional do Cigano, no dia 28 de maio de 2015, pelo Ministério da Educação.

Em 2016, o planejamento de ações aprovados pelo Grupo de Trabalho para difusão do documento com a capacitação dos profissionais nas organizações políticas educacionais nos estados, municípios e Distrito Federal sofreu solução de continuidade. Diante do cenário de instabilidade política brasileira instaurada, a temática educacional do Povo Romani não foi prioridade na pauta política da nova gestão do Ministério da Educação.

\footnotetext{
${ }^{4}$ Relatório executivo do evento disponível em http://www.amsk.org.br/imagem/marcosLegais/SEPPIR_relatorioexecutivo-Brasil-cigano.pdf

${ }^{5}$ Resolução no 3, de 16 de maio 2012, do Conselho Nacional de Educação, Câmara de Educação Básica (CNE/CEB).

${ }^{6}$ Documento disponível em https://www.amsk.org.br/imagem/marcosLegais/Educacao_secadi_ciganos_documento_orientador_para_sistemas_ens.pdf
} 
Em 2019, a nova conformação política brasileira promove a reorganização ministerial e extingue a SECADI ${ }^{7}$ da estrutura organizacional do Ministério da Educação. A ruptura do diálogo democrático com as organizações não governamentais, em especial, com aquelas defensoras dos direitos humanos.

\section{Saúde}

Em 2015, a Secretaria de Gestão Estratégica e Participativa do Ministério da Saúde (SGEP/MS) por intermédio do Departamento de Apoio à Gestão Participativa e ao Controle Social (DAGEP/SGEP/MS) iniciou o trabalho para colheita das percepções e aprendizados coletivos das/dos romani - ciganas/ciganos - sobre a atenção básica à saúde. Em cumprimento ao disposto da Convenção no 169 da Organização Internacional do Trabalho, e aos marcos legais vigentes na área da saúde.

Em parceria com a AMSK, o DAGEP coordenou oficinas macrorregionais de políticas de equidade do Sistema Único da Saúde (SUS) para o Povo Romani realizadas entre os anos 2015 a 2017. As atividades desenvolvidas nas seguintes comunidades romani - ciganas: da etnia Kaldarash do município de Aparecida de Goiânia, Goiás; e da etnia Calon dos municípios de Joinville, Santa Catarina, de Santa Fé do Sul, São Paulo, e de Camaçari, Bahia.

As oficinas contaram com o apoio das Secretarias Municipais e Estaduais de Saúde que oportunizaram a participação de agentes públicos para prestação de serviços à comunidade. Importante ação que rompeu com os preconceitos de ambas as partes do público participante.

Os resultados das oficinas contribuíram para a elaboração e publicação do guia Subsídios para o atendimento à saúde do Povo Cigano lançada no ano de 2016 pelo Ministério da Saúde. Objetivo geral fortalecer as capacidades dos trabalhadores de saúde para melhoria no atendimento à população romani - cigana - do país.

Mesmo com a conjuntura política instaurada no país em 2016, que promoveu várias mudanças nas estruturas organizacionais no poder executivo federal, a nova administração da Secretaria de Gestão Estratégica e Participativa do Ministério da Saúde (SGEP/MS) manteve a pauta política de discussões de atenção básica à saúde às comunidades romani - cigana.

Em 2017, as ações do Departamento de Apoio à Gestão Participativa e ao Controle Social (DAGEP/SGEP/MS) foram continuadas. Criou o Grupo de Trabalho para a Saúde Cigana priorizando a participação de representantes das comunidades participantes das oficinas macrorregionais.

\footnotetext{
${ }^{7}$ Souza, Marcia F. (2019). A extinção da SECADI e o campo da Educação na conjuntura atual. Disponível em http://www.justificando.com/2019/01/17/extincao-secadi-campo-educacao-conjuntura-atual/
} 
Em face de os resultados, o Ministério da Saúde promoveu a participação da AMSK para auxiliar no âmbito das discussões internacional da política "Etnicidade e Saúde" realizada pela Organização Pan-americana de Saúde das Américas da Organização Mundial da Saúde (OPAS/OMS).

O lançamento oficial da "Política sobre Etnicidade e Saúde" na região das Américas ocorreu na $29^{a}$ Conferência Sanitária Pan-Americana realizada no período de 25 e 26 de setembro de 2017, em Washington, DC, Estados Unidos. Esta política baseia-se na necessidade de uma abordagem intercultural da saúde com o reconhecimento dos saberes e práticas, tradições e costumes dos grupos étnicos. O respeito mútuo na criação de soluções conjuntas que contribuam para melhorar os resultados da saúde e avançar para a saúde universal.

Os trabalhos continuados no Ministério da Saúde tiveram como resultado a homologação da Portaria $n^{\circ}$ 4.384, de 28 de dezembro de 2018, que institui no âmbito do Sistema Único de Saúde (SUS) a Política Nacional de Atenção Integral à Saúde do Povo Cigano/Romani.

Em 2019, a execução das ações programadas à implantação dessa política sofre solução de continuidade, em face de a extinção da Secretaria de Gestão Estratégica e Participativa (SGEP/MS) da nova estrutura organizacional do Ministério da Saúde.

\section{Assistência Social}

A AMSK como membro do Conselho Nacional de Assistência Social (CNAS), gestão 2016 a 2018, teve a oportunidade de inserir na pauta de discussão política do Sistema Único da Assistência Social (SUAS) os obstáculos enfrentados pela população romani - cigana - ao acesso dos programas socioassistenciais desenvolvidos pelo Ministério de Desenvolvimento Social (MDS).

As ações da assistência social no Sistema Único da Assistência Social (SUAS) são organizadas em dois tipos de proteção: básica e especial. Desenvolvidas e/ou coordenadas pelas unidades públicas como os Centros de Referência da Assistência Social (CRAS), Centros de Referência Especializados de Assistência Social (CREAS) e Centros de Referência Especializado para a População em Situação de Rua (Centro POP) e de forma complementar, pela Rede Socioassistencial Privada do SUAS.

Em junho de 2017, a AMSK foi convidada pela Secretaria Nacional de Assistência Social (SNAS/MDS) para realizar oficina ${ }^{8}$ de capacitação aos seus servidores para conhecimento da história do Povo Romani e das questões afetas ao acesso aos serviços do SUAS.

\footnotetext{
${ }^{8}$ MDS promove oficina sobre atendimento dos povos ciganos no SUAS, disponível em http://mds.gov.br/area-deimprensa/noticias/2017/junho/mds-promove-oficina-sobre-atendimento-dos-povos-ciganos-no-suas
} 
Como resultado da oficina, a SNAS elaborou e lançou o Informativo Atendimento a Povos Ciganos no SUAS. A publicação propagada na rede das unidades de atendimento socioassistenciais do país, total 8.252 Centros de Referência de Assistência Social - CRAS (Censo SUAS, 2017). O objetivo de subsidiar os profissionais do Sistema Único de Assistência Social (SUAS) no atendimento adequado a população romani - cigana - respeitando suas tradições e cultura.

Relevante ação de distribuição do informativo na rede das unidades de atendimento socioassistenciais do país que promoveu na gestão pública estadual, municipal e do Distrito Federal a inclusão em seus processos e programas de assistência social à busca ativa, em seus territórios, das famílias romani - cigana - em situação de pobreza e extrema pobreza para a efetivação nos registros do Cadastro Único.

O Cadastro Único é um instrumento da política socioassistencial para a seleção e a inclusão de famílias de baixa renda em programas federais, sendo usado obrigatoriamente para a concessão dos benefícios do Programa Bolsa Família, da Tarifa Social de Energia Elétrica, do Programa Minha Casa Minha Vida, da Bolsa Verde, entre outros.

O Tabulador de Informações do Cadastro Único é uma ferramenta que permite conhecer as características socioeconômicas das famílias e pessoas incluídas no Cadastro Único (domicílio, faixa etária, trabalho, renda etc.) bem como saber quais famílias são beneficiárias do Programa Bolsa Família. Em março de 2019, registra 10.990 famílias romani - cigana -, sendo o total de 24.514 pessoas, das quais $52 \%$ feminino e $48 \%$ masculino. Os beneficiários do Programa Bolsa Família, com renda familiar per capita de $\mathrm{R} \$ 89,00$ até $\mathrm{R}$ \$ 178,00 mensal, 5.323 total de famílias, e 16.395 total de pessoas.

Do total de pessoas beneficiárias constam presentes nas 27 unidades federativas do país, com maior concentração populacional na Bahia 33\% (5.459), Minas Gerais 14\% (2.231), Goiás 11\% (1.788), Maranhão 6\% (1.026) e São Paulo 6\% (931).

Importante destacar que o Cadastro Único para Programas Sociais reúne informações socioeconômicas das famílias brasileiras de baixa renda - aquelas com renda mensal de até meio salário mínimo por pessoa. Essas informações permitem conhecer as reais condições de vida da população romani - cigana - no país. No entanto, ainda não há a coleta de dados sobre o pertencimento étnico - Kaldarash, Lovara, Matchuaia, Boyasha, Rudari, Horaranô, Calon e Sinti.

A AMSK considera o Cadastro Único a única fonte de dados oficial do governo brasileiro para geração de informação sobre o quantitativo demográfico do Povo Romani no país. Haja vista que esse programa apresenta registros contínuos mensal de atendimento. 
Por esta razão não compreendemos os números anunciados em 2019 pela nova gestão do Ministério da Mulher, da Família, e Direitos Humanos (MMFDH), do governo brasileiro afirmar o quantitativo demográfico do Povo Romani de 1.200.000 existentes no Brasil. Esse dado foi retirado de qual fonte? Haja vista que o Instituto Brasileiro de Geográfica e Estatística (IBGE), órgão oficial do governo federal para geração de dados no país, até a presente data não efetivou o censo demográfico dos romani - ciganos - nas 27 unidades federativas do Brasil. E no Censo 2020 também não constará na coleta de dados. Então, a AMSK afirma que não há número absoluto sobre a população romani - cigana - no país, o que há são teorizações fundadas no subjetivismo do "eu acho que", ou seja, achismo.

Em 2019, dada a conformação política brasileira o Ministério de Desenvolvimento Social (MDS) passa a ser denominado Ministério da Cidadania. O Sistema Único da Assistência Social (SUAS) tem sido afetado com os cortes de recursos financeiros e de repasses aos órgãos gestores municipais. Como consequência os romani e não romani têm sido afetados pelo cancelamento dos benefícios do Programa Bolsa Família.

\section{Os desafios a serem superados}

Ao longo desses 10 anos da AMSK, com as ações de advocacy - argumentação e defesa de causas e direitos - compreendemos que se a gestão pública não for demandada pela sociedade, não haverá efetividade na aplicação das políticas públicas vigentes para o atendimento das necessidades da população. Em especial, daquelas marginalizadas por suas diferenças culturais, sociais e econômicas.

As demandas do Povo Romani passaram a ser conhecidas e a compor o rol das pastas políticas brasileira, graças ao empenho de membros comunitários e de organizações associativa à participação nos espaços de discussão e de formulação das políticas públicas. Essa atuação tem sido um meio de influenciar e contribuir na construção das políticas públicas locais, em face de a relação entre os diversos atores sociais e o Estado. Também gerar conhecimento aos agentes públicos municipal sobre as situações de enfrentamentos ao racismo estrutural presentes nas instituições públicas de atendimento à saúde, educação, assistência social, trabalho, habitação e segurança pública.

Nesse contexto, a AMSK buscou visibilizar as ações políticas desenvolvidas no âmbito internacional. Promoveu no ano de 2012 a participação de romani - cigana/cigano - defensores dos direitos humanos internacionais, no evento Ciclo de debates ciganos: Uma história invisível, nos dias 9 e 10 de abril, realizado na Universidade de Brasília. 
Os defensores dos direitos humanos Bruno Gonçalves - Mediador cigano e membro da Associação Letras Nômadas, Portugal -, Ana Dalila Baos - Processo Organizativo del Pueblo Rrom Gitano (PRORROM), Colômbia -, e Juan de Dios Ramirez Heredia - Presidente da Unión Romani, Espanha, contribuíram para avançar nas discussões políticas junto ao governo brasileiro. Apresentaram à então Secretaria Especial de Políticas de Promoção da Igualdade Racial (SEPPIR) da Presidência da República (SEPPIR) os avanços realizados em seus países, com a participação dos romani, no processo de elaboração e aplicação das políticas públicas.

Desde então, o governo brasileiro passou a visibilizar nas políticas sociais o reconhecimento da identidade cultural do Povo Romani. Entretanto, apesar das conquistas, em 2019, a atual conformação política brasileira evidencia a supressão de a discussão das reivindicações do Povo Romani na área de educação e saúde. Na área da assistência social ainda mantém a família romani - cigana - nos registros do Cadastro Único para programa sociais. Mas, o quantitativo de beneficiários do Programa Bolsa Família sendo diminuído.

$\mathrm{Na}$ área da política de promoção da igualdade racial promovida pela atual Secretaria Nacional de Políticas de Promoção da Igualdade Racial do Ministério da Mulher, da Família e dos Direitos Humanos (SNPIR/MMFDH) descartou as ações realizadas pelo Grupo de Trabalho Interministerial (GTI) desde 2013, e sinaliza a ênfase ao assistencialismo apenas as comunidades da etnia Calon, em situação de acampamento, moradia em tendas, em terreno público municipal. Não apresenta até o momento um plano de ação para promoção da igualdade e a proteção do Povo Romani contra todas as formas de discriminação, racismo e xenofobia.

Diante dos fatos, nós romani - ciganas/ciganos - atuantes na incidência política, no estudo e pesquisa temos ciência que precisamos avançar no fortalecimento das capacidades internas comunitárias para que tenham entendimento dos fluxos de atendimento nos serviços públicos ofertados. Ampliar seus conhecimentos para defenderem seus direitos de cidadãs e cidadãos brasileiros quando forem violados pela presença do racismo estrutural. Mas, sobretudo, para que sejam mais participativos na construção de um processo de mudança em prol de todos que compõe a vida em sociedade. Agentes de mudança incentivando a cultura de participação e de corresponsabilidade pelo bem-estar social para a prática de ações transformadoras que fortaleçam a coletividade.

Por fim, a todas e todos romani e não romani participantes deste evento possam inserir em suas trajetórias de vida a reflexão sobre as palavras proferidas por minha avó, Dona Fia Vidal: Que a herança de um povo nunca seja a fome, a miséria, o preconceito, a discriminação e o racismo. 


\section{Bibliografia}

Cavalcante, L. V. (2019). História, identidade e dinâmicas territoriais do povo rom no Brasil. Dissertação de mestrado. Brasília:Universidade de Brasília. Brasil.

Constituição da República Federativa do Brasil. (1988). Brasília: Senado Federal.

Costa, E. M. L. da. (1997). O povo cigano em Portugal e terras de além-mar (séculos XVI a XIX). Fergráfica, Lisboa. ISBN 972-8186-36-3.

Cunha, J. R. D. (2015). "Olhe nosso Centro! Aqui somos todos ciganos": construções identitárias e dinâmicas políticas entre os ciganos de Sousa - PB. Dissertação de mestrado, Universidade Federal de Pernambuco, Recife, Brasil. Acedido em: 15 outubro 2019, em: https://repositorio.ufpe.br/handle/123456789/27668

Decreto Presidencial de 25 de maio de 2006. Presidência da República do Brasil. Acedido em: 12 outubro 2019, em: http://www.planalto.gov.br/ccivil_03/_Ato2004-

2006/2006/Dnn/Dnn10841.htm

Decreto-lei no 6.040/2007 de 7 de fevereiro. Presidência da República do Brasil. Ministério de Estado do Meio Ambiente. Ministério de Estado do Desenvolvimento Social e Combate à Fome. Acedido em: 12 outubro 2019, em:

http://www.planalto.gov.br/ccivil_03/_Ato2007-2010/2007/Decreto/D6040.htm

Decreto $\mathrm{n}^{\circ}$ 10.088/2020 de 5 de novembro. Presidência da República do Brasil. Acedido em: 5 julho 2020, em: http://www.planalto.gov.br/ccivil_03/_Ato20192022/2019/Decreto/D10088.htm

Ministério de Estado de Desenvolvimento Social do Brasil. Secretaria Nacional de Desenvolvimento Social - SNAS/MDS. (2017). Informativo atendimento a povos ciganos no SUAS. Acedido em: 21 outubro 2019, em:

https://www.mds.gov.br/webarquivos/publicacao/assistencia_social/informe/Povos_Cigan os.pdf

Ministério de Estado de Desenvolvimento Social do Brasil. Secretaria de Avaliação e Gestão da Informação - SAGI/MDS. (2018). Censo SUAS 2017 - Análise dos componentes sistêmicos da política nacional de assistencial social. Acedido em: 21 outubro 2019, em: https://aplicacoes.mds.gov.br/sagirmps/ferramentas/docs/Censo\%20SUAS\%202017\%20( 1).pdf

Ministério de Estado da Educação do Brasil. Secretaria de Educação Continuada, Alfabetização, Diversidade e Inclusão - SECADI/MEC. (2014). Ciganos - Documento orientador para o Sistema de Ensino. Acedido em: 20 outubro 2019, em: http://www.amsk.org.br/imagem/marcosLegais/Educacao_secadi_ciganos_documento_ori entador_para_sistemas_ens.pdf

Ministério de Estado da Saúde do Brasil. (2016). Subsídios para o cuidado à saúde do povo cigano. Brasília: Ministério da Saúde. ISBN 978-85-334-2437-1. Acedido em: 20 outubro 2019, em:

http://bvsms.saude.gov.br/bvs/publicacoes/subsidios_cuidado_saude_povo_cigano.pdf

Organização Mundial de Saúde. Organização Pan-americana de Saúde. (2017). Política sobre etnicidade e saúde (CSP29/7, Rev. 1, 28 September 2017). Washington. Acedido em: 21 
outubro 2019, em:

https://www.paho.org/bra/index.php?option=com_content\&view=article\&id=5506:paisesdas-americas-se-comprometem-a-melhorar-saude-de-populacoes-indigenasafrodescendentes-e-povos-ciganos \&Itemid $=820$

Portaria n ${ }^{\circ}$ 10/2014 de 28 de fevereiro. Ministério de Estado da Educação do Brasil. Acedido em: 20 outubro 2019, em:

http://pesquisa.in.gov.br/imprensa/jsp/visualiza/index.jsp?data=05/03/2014\&jornal=2\&pa gina $=42 \&$ total Arquivos $=96$

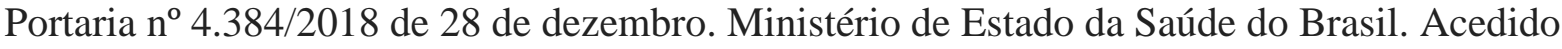
em: 21 outubro 2019, em: https://bvsms.saude.gov.br/bvs/saudelegis/gm/2018/prt4384_31_12_2018.html

Resolução no 3/2012 de 16 de maio. Ministério de Estado da Educação do Brasil. Conselho Nacional da Educação. Acedido em: 20 outubro 2019, em: http://portal.mec.gov.br/index.php?option=com_docman\&view=download\&alias=10770rceb003-12-pdf-1\&category_slug=maio-2012-pdf\&Itemid=30192

Soria, A. P. C. B. (2008). Entre a dor de ser "cigano" e o orgulho de ser romà: Aproximação à literatura romani e a auto-representação dos romà em duas obras de Jorge Nedich. Dissertação de mestrado, Universidade de Brasília, Brasília, Brasil. Acedido em: 15 outubro 2019, em: https://repositorio.unb.br/handle/10482/1365

Soria, A. P. C. B. (2015). “Juncos ao vento": literatura e identidade romani (cigana) : El alma de los parias, de Jorge Nedich. Tese de doutorado, Universidade de Brasília, Brasília, Brasil. Acedido em: 5 julho 2020, em: https://repositorio.unb.br/handle/10482/19111

Souza, M. F.(2019). A extinção da SECADI e o campo da Educação na conjuntura atual. Em: Justificando. Acedido em: 20 outubro 2019, em: http://www.justificando.com/2019/01/17/extincao-secadi-campo-educacao-conjunturaatual/

Ministério de Estado de Cidadania do Brasil. Secretaria de Avaliação e Gestão da Informação - SAGI/MC. Tabulador de Informações do Cadastro Único. Acedido em: 14 maio 2019, em: https://aplicacoes.mds.gov.br/sagi/portal/index.php?grupo=86

UNFPA. (2001). Conferência Mundial contra o Racismo, a Discriminação Racial, a Xenofobia e Formas Correlatas de Intolerância. Acedido em: 12 outubro 2019, em: http://www.unfpa.org.br/Arquivos/declaracao_durban.pdf 


\section{PARTE IV \\ CIGANOS, CASAMENTO E ENVELHECIMENTO}





\title{
Capítulo 11. \\ La expansión de los matrimonios mixtos \\ entre los Gitanos/Calé de España. Análisis de un caso
}

\author{
JUAN F. GAMELLA ${ }^{1}$ \\ Antropólogo e Professor Catedrático de Antropologia na Universidade de Granada \\ gamella@ugr.es
}

Resumo: Os Ciganos ou Calé de Espanha mostraram uma preferência secular pelo casamento dentro de sua própria comunidade etnocultural. Embora as uniões mistas fossem conhecidas desde as primeiras décadas desde a sua presença no país, o nível total de casamentos mistos permaneceu baixo (abaixo de 5\%) e concentrou-se em algumas comunidades e famílias. No entanto, nas últimas décadas, tem havido um aumento notável de casamentos mistos em várias regiões da Espanha. Em algumas comunidades, os casamentos mistos tornaram-se muito comuns e geraram novas formas de identificação e afiliação. Neste artigo abordamos este tema a partir de dados da pesquisa etnográfica e históricodemográfica dos Ciganos residentes em uma região da Andaluzia. Numa amostra representativa de 3.336 famílias, encontramos 421 (12\%) uniões mistas de 1900 a 2006. A proporção aumentou para mais de $24 \%$ desde 1990, e, em algumas localidades, hoje quase metade de todos os casamentos Ciganos são mistos. As diferenças locais parecem decisivas, e são mais as mulheres Ciganas que estão a casar fora das famílias ciganas.

Palavras-chave: casamento misto, Gitano / Cale, Espanha, Grupos Romani

\begin{abstract}
Resumen:The Gitanos or Calé of Spain have shown a secular preference for marrying within their own ethnocultural community. Although mixed unions were known since the first decades of their presence in the country, the total level of intermarriage remained low (under 5\%) and concentrated on some communities and families. However,

\footnotetext{
${ }^{1}$ Juan F. Gamella is an anthropologist, and professor of Anthropology at the Universidad de Granada. Since 1993 he has been studying different elements of the Gitano or Calé culture of Spain, and since 2003 he has also researched the transnational migration of Romanian Roma into Western Europe. He has published three books and over 30 papers based on these researches. He is presently comparing the institutional forms generated by the social organization of reproduction among several Romani groups, that is, the interfaces between kinship, gender and fertility regimes, and how they shape and are shaped by larger political and economic transformations.
} 
in the last decades there has been a remarkable increase in mixed marriages in several regions of Spain. In some communities mixed marriages are becoming very common and are generating new forms of identification and affiliation. Here we address this topic using data from the ethnographic and demographic-historical research of the Gitano people of an area of Andalusia. In a reconstitution of a representative sample of 3,336 families we found 421 (12\%) mixed unions from 1900 to 2006. The proportion has increased to over $24 \%$ from 1990, and, in some localities, today near half of all Gitano marriages are mixed. Local differences seem decisive, and more Gitano women than men are marrying out.

Keywords: intermarriage, Gitano/Cale, Spain, Romani Groups

\section{Introducción}

Los gitanos o calé españoles han mostrado durante siglos una marcada preferencia por casarse con personas de su propio grupo etnocultural. La endogamia étnica ha constituido un habitus decisivo en su permanencia como un grupo distinto con un marcado sentido de identidad colectiva (San Román 1976: 143-147; Lagunas 2005: 252-53; Gómez Alfaro 1999: 35-36). Aunque las uniones mixtas se dieron ya en las primeras décadas de su estancia en España, su proporción se ha mantenido relativamente baja (menos del 5\% en total), concentrándose además en algunas comunidades y redes familiares (Gómez Alfaro 1999; Leblon 1985). Por otro lado, el matrimonio con gitanos tampoco estaba bien visto por la población mayoritaria (Leblon 1985: 62).

En las últimas décadas, sin embargo, observamos un crecimiento sostenido de los matrimonios mixtos en familias gitanas de muchos pueblos y ciudades españolas. En algunas redes familiares, las parejas mixtas se han convertido en normales y hasta esperadas. Los hijos y nietos de estas parejas se asimilan a la minoría o a la mayoría, pero también están generando nuevas formas de identificación y afiliación que rompen los discursos rígidos y racializantes que enfatizan la oposición irreconciliable de las identidades y los universos sociales de "payos y gitanos".

El crecimiento de las uniones mixtas supone la transformación de los sistemas de parentesco, género y matrimonio que han constituido las raíces más importantes de la reproducción de la diferencia y la experiencia de ser "otros" (Martín \& Gamella, 2005). El cambio esta siendo rápido y transformador, pero no es uniforme. Los matrimonios con 
payos o payas siguen siendo rechazados en algunas comunidades y redes familiares gitanas.

\section{Matrimonios mixtos e integración sociocultural}

Las uniones entre personas de distintas nacionalidades, religiones y grupos étnico/raciales han crecido notablemente en las últimas décadas en muchas regiones del mundo. Esto se debe en parte al incremento global de los procesos migratorios (Osanami et al. 2016), pero también a transformaciones internas a varias sociedades plurales donde, por usar el modelo de Richard Alba y sus colaboradores, observamos el ascenso de grupos minoritarios en la estructura social a la par que la reducción de sus diferencias culturales con la mayoría dominante. Estos procesos generan lo que estos autores definen como una nueva forma de asimilación que resulta no tanto en aculturación como en una "expansión del mainstream" (Alba \& Nee 2003; Alba \& Duyvendak 2019). Las uniones mixtas son precisamente "celebradas a menudo como un signo de integración" de las minorías en las instituciones dominantes (Osanami et al. 2016: 498).

En Estados Unidos, por ejemplo, los matrimonios mixtos entre grupos étnico/raciales se han multiplicado por cinco entre 1967 y 2015, pasando de un 3 a un 17\% (Livingston \& Brown 2017: 5). En paralelo, las normas y actitudes sociales dominantes son hoy mucho más favorables al mestizaje, particularmente en los estados del Oeste y el Norte. Las diferencias de género en esos matrimonios apuntan a la interseccionalidad de los procesos involucrados y las desigualdades que subyacen a los procesos de asimilación (Rumbaut 1997; Portes \& Zhou 1993). Así, no se aprecia el mismo crecimiento de las uniones mixtas entre las mujeres afroamericanas, un $12 \%$ de las recién casadas, que de las "asiáticas, tres veces más, un 36\% (Livingston \& Brown 2017: 6). Los procesos de racialización siguen siendo decisivos en la aceptación del mestizaje en Norteamérica.

En Europa occidental la inmigración internacional ha producido un aumento del entrecasamiento entre mayorías nacionales y diversas minorías inmigrantes o autóctonas (Rodríguez-García 2006). Aquí, en contraste con EEUU se aprecia que la diferencia religiosa parece crear en ciertos grupos (musulmanes, hindúes, sijs...) una barrera para el entrecasamiento más difícil de cruzar que la que generan las diferencias percibidas como"raciales" (Lucassen \& Laarman 2009). 


\section{Procesos sociales y culturales}

Los principales modelos teóricos ven el crecimiento de los matrimonios mixtos como resultado de la reducción de la distancia social y del incremento de la convergencia y la compatibilidad cultural. En algunos casos se habla de nuevas formas de asimilación a la mayoría (Alba \& Nee 2003), pero también de ampliación de los propios criterios que definen las mayorías y que se han expandido en términos culturales, étnicos y religiosos (Alba \& Duyvendak 2019). El aumento de los matrimonios mixtos también se vincula con cambios estructurales, porque "en general la movilidad social ascendente se asocia con un incremento en las tasas de matrimonios mixtos. Por lo tanto el mestizaje puede también considerarse como un indicador de la parte estructural del proceso de integración" (Lucassen \& Laarman 2009: 53).

En nuestro caso la expansión del mestizaje se ha visto facilitada por los nuevos patrones de interacción personal y familiar generados en las escuelas e institutos, los centros públicos de salud, y los nuevos complejos de viviendas a donde los gitanos se han mudado junto a vecinos payos. Estos procesos de incorporación a instituciones comunes tienen antecedentes más antiguos de lo que suele creerse. Por ejemplo, ya había niños gitanos en escuelas infantiles en 1785, como se aprecia en una lectura detenida de los censos de gitanos que se hicieron entonces. Sin embargo, se han acelerado y generalizado en la España democrática desde 1978, según los gitanos españoles han sido incorporados en las instituciones y servicios públicos del emergente estado del bienestar, como las de la enseñanza pública y obligatoria, las de la atención sanitaria universal y gratuita, los programas de vivienda y los sistemas de pensiones, subsidios y rentas básicas. Estos cambios, que corresponderían a lo que Alba y Nee (2003) llamaron "asimilación estructural”, han roto la segregación secular que se vivía en muchas localidades, donde payos y gitanos vivían separados por poderosas barreras físicas y, sobre todo, simbólicas. La creciente participación de las personas gitanas en las instituciones comunes, ha transformado la vida diaria y las relaciones étnicas en muchas localidades.

Se han producido también transformaciones en las mentalidades y en las conciencias individuales, aceleradas por la generalización de la alfabetización gitana y el acceso al mundo escrito y a los medios de comunicación de masas, ayer la radio, luego la televisión y hoy internet y las redes digitales asequibles mediante smartphones y ordenadores. Todos estos cambios han reducido la distancia social y la diferencia cultural entre los gitanos y sus vecinos payos, lo que ha facilitado el aumento de los matrimonios mixtos. 
No obstante, los procesos de homogeneización cultural no han sido uniformes ni unilaterales. Ha habido nuevos procesos de diferenciación cultural, como la expansión del culto pentecostal de la Iglesia Evangélica de Filadelfia, casi exclusivamente regido y seguido por personas gitanas (Cantón 2004), o el crecimiento de un asociacionismo gitano más o menos independiente; o el mantenimiento de valores y expectativas que han desaparecido en la mayoría, por ejemplo, la valoración y exigencia de la virginidad femenina de cara al matrimonio (Martín \& Gamella 2005; Gay Blasco 1999).

En este artículo analizaremos de forma resumida el crecimiento de las uniones mixtas que hemos observado en una región española donde los gitanos han sido la principal minoría étnica durante siglos. Estudiaremos los niveles de mestizaje a lo largo del siglo XX a partir de los datos obtenidos en una investigación que ha combinado métodos etnográficos y de demografía histórica.

\section{Métodos y fuentes de datos}

Los datos que utilizamos aquí provienen de una investigación desarrollada durante casi dos décadas con la población gitana de 22 municipios contiguos de la provincia de Granada. La ciudad de Guadix, centro administrativo y de comunicaciones de los más antiguos de España, se sitúa en el centro de la región estudiada. A finales del siglo XX, unos 7000 gitanos residían aquí para un total de 50.000 habitantes, un 14\% de la población total. La proporción de población gitana en algunas de las localidades estudiadas es de las más altas de Europa occidental (Gamella 1996). El área ofrece una especie de microcosmos de las condiciones de vida de los gitanos españoles. La mayoría de las situaciones socioeconómicas y residenciales que encontramos en otras regiones también aparecen aquí, aunque obviamente no en la misma proporción. Hay algunas formas de vida autóctonas, como la residencia en casas-cueva, que abundan en esta zona de forma idiosincrásica.

Nuestra investigación en esta zona comenzó en 1993 y se intensificó desde 2001. La recogida sistemática de datos demográficos en todas las localidades terminó en 2007. Nuestro trabajo etnográfico ha continuado hasta hoy. En otras publicaciones hemos explicado los métodos de recogida y análisis de datos utilizados en esta investigación (Martin \& Gamella 205; Gamella \& Martín 2017; Gamella 2019).

En la zona estudiada muchas familias gitanas han vivido en situaciones de pobreza durante siglos; pero también hay familias gitanas que han disfrutado de condiciones de 
prosperidad y cierta abundancia. Con los altibajos asociados a los períodos de expansión y crisis económica, las familias gitanas han visto aumentar notablemente su bienestar y su participación en los recursos públicos desde los años 70 y, particularmente, con la instauración del régimen democrático. Aunque en general los gitanos de esta región son temporeros agrarios y vendedores ambulantes, también practican una variedad de oficios poco especializados, combinándolos a menudo de forma estacional.

En las últimas décadas las familias gitanas han logrado pensiones de jubilación para casi todos sus mayores, y obtenido subsidios o rentas públicas para aquellos que trabajan eventualmente en el campo o tienen cargas familiares y situaciones de necesidad. Además se han integrado de forma generalizada en el sistema escolar público o concertado, y han accedido a una atención médica gratuita y casi-universal. Muchas familias son dueñas de sus viviendas que han arreglado con su trabajo y también con ayudas públicas, y a menudo tienen otras pequeñas propiedades. Hay ya universitarias, profesionales y funcionarias entre las personas gitanas, que ofrecen nuevos modelos de vida y referencia para todos (Gamella 2011).

Desde los años 60 y 70 del pasado siglo, muchos gitanos y gitanas de estas comarcas emigraron a otras regiones de España e incluso de Europa en busca de mejores empleos y condiciones de vida. Muchos retornaron al cabo del tiempo, mientras hubo familias que se quedaron en Murcia, Valencia, Cataluña, Baleares o Madrid. Por tanto, los procesos de mestizaje aquí estudiados se han desarrollado también en redes familiares gitanas de toda España.

\section{Identificación, afiliación}

La auto-identificación ha sido el criterio fundamental que ha guiado nuestra investigación. Hemos considerado como sujetos de estudio a aquellas personas que se han identificado a sí o a sus progenitores como gitanos o gitanas. En todos los casos, esa identificación se basaba en una ideología vernácula de la filiación y la descendencia (Scheffler 2018), es decir, que todas las personas que se definen como gitanos tienen padres o madres y antepasados que también eran gitanos. Por otro lado, en casi todos los casos estas personas eran también reconocidas como gitanos por sus vecinos y vecinas. Es decir, la identidad gitana es casi siempre un hecho público en los pueblos y barrios donde se ha desarrollado este trabajo. 
En cuanto a la investigación en archivos, hemos contado con la ayuda de amigos gitanos residentes en esas localidades para trazar un listado de los apellidos y redes familiares de partida que nos han permitido explorar exhaustivamente (durante casi una década) los archivos parroquiales y civiles locales. Una vez incorporada la información a nuestra base genealógica y demográfica, todos los nombres han sido eliminados para respetar el anonimato de los sujetos y la confidencialidad de las fuentes empleadas.

Aunque la filiación étnica no figura en los archivos españoles y los términos "gitano" o "gitana" están teóricamente prohibidos desde el siglo XVII, encontramos referencias al carácter de "castellano nuevo" de los padres de niños inscritos en registros civiles y parroquiales de la zona hasta la segunda década del siglo XX. Estos datos permiten confirmar genealogías enteras.

\section{Etnografía y etnohistoria}

Durante más de dos décadas hemos visitado regularmente a muchos de nuestros amigos y amigas gitanos en la zona, compartiendo con ellos numerosos momentos de sus vida cotidiana así como las ceremonias y ritos de paso que jalonaban su existencia. Personalmente me he convertido en el fotógrafo familiar de muchas de estas redes de parientes. He filmado y fotografiando 16 bodas, cinco bautizos y dos comuniones, además de prácticas funerarias y varias celebraciones del Día de Los Quintos y el Día de los Difuntos. Cinco de las bodas fotografiadas eran mixtas. Nuestra investigación etnográfica más intensa la hemos desarrollado en cinco localidades que cuentan con importantes poblaciones gitanas y ahí, sobre todo con algunas redes familiares con las que hemos desarrollado relaciones de confianza que se extienden ya durante muchos años. Además, hemos realizado más de 175 entrevistas biográficas, sobre todo a ancianas y ancianos gitanos, tratando de reconstruir la historia familiar y local de los gitanos locales. Algunas de esas "historias de vida" las hemos incorporado en anteriores publicaciones (Gamella 2000; Gamella \& Martin 2017).

\section{La investigación histórico-demográfica}

En paralelo a la investigación etnográfica hemos desarrollado un proyecto de reconstrucción demográfica y genealógica de la población gitana total de la zona desde el inicio del Registro Civil, en 1871. Esa reconstrucción incorpora información anónima de más de 19.000 personas gitanas nacidas entre 1722 y 2007 . En total, hemos seleccionado una 
muestra de 3.336 parejas con sus hijos que creemos incluye a todas las parejas comparables que se han formado en la zona, por lo que creemos tiene un alto grado de representatividad (ver los criterios de selección en Gamella 2019). Los datos cuantitativos de este artículo provienen de esa muestra.

\section{¿Matrimonios o uniones de derecho común?}

Los gitanos o calé han desarrollado sistemas autóctonos para establecer uniones socialmente válidas, las cuales suelen tener para ellos la consideración de matrimonio. A menudo tales uniones se formalizaron por la Iglesia o el Estado mucho después de que la pareja conviviera y tuviera hijos. Un tercio de la uniones gitanas en nuestra muestra nunca se oficializaron. Las formas de establecer una unión de pareja válida para la comunidad son diversas y forman un espectro de actuaciones y representaciones que va desde la cohabitación socialmente aceptada que es corroborada con el nacimiento de los hijos, a las elaboradas ceremonias públicas a las que pueden acudir cientos de invitados y que pueden incluir bodas religiosas y casamientos gitanos (Gamella 2000).

Los matrimonios mixtos resaltaban bastante en la reconstrucción familiar, tanto por los apellidos, el lugar de origen y de residencia del cónyuge no gitano, como por los apellidos de sus padres y abuelos. El carácter mixto de una pareja es un hecho público en cada pueblo; es parte del conocimiento local compartido. No es difícil obtener información respecto a ellas, tanto en el entorno calé como en el de los "castellanos" o vecinos.

Además de estudiar todas las parejas comparables desde 1900 a 2006, hemos seguido a unas 200 parejas mixtas en la última década, tanto en interacciones y conversaciones directas con miembros de las respectivas familias, como a través de su participación en redes digitales y aplicaciones públicas de internet. Toda la información recogida se ha anonimizado y mantenido estrictamente confidencial. 
Tabla 1. Matrimonios mixtos en la población gitana de 22 municipios contiguos de la provincia de Granada, España (1900 a 2006)

\begin{tabular}{ll|ll|ll|ll}
\hline Década & Total & \multicolumn{2}{|c|}{ Matrimonios mixtos } & \multicolumn{2}{|c|}{ Esposa gitana } & \multicolumn{2}{c}{ Marido gitano } \\
de la unión & $\mathrm{N}$ & $\mathrm{N}$ & $\%$ & $\mathrm{~N}$ & $\%$ & $\mathrm{~N}$ & $\%$ \\
\hline $\mathbf{1 9 0 0}$ to 1909 & 94 & 3 & 3,2 & 0 & 0 & 3 & 100 \\
$\mathbf{1 9 1 0}$ to 1919 & 116 & 3 & 2,6 & 0 & 0 & 3 & 100 \\
$\mathbf{1 9 2 0}$ to 1929 & 163 & 5 & 3,1 & 3 & 60 & 2 & 40 \\
$\mathbf{1 9 3 0}$ to 1939 & 196 & 6 & 3,1 & 2 & 33,3 & 4 & 66,7 \\
$\mathbf{1 9 4 0}$ to 1949 & 246 & 22 & 8,9 & 12 & 54,5 & 10 & 45,5 \\
$\mathbf{1 9 5 0}$ to 1959 & 316 & 20 & 6,3 & 11 & 55 & 9 & 45,0 \\
$\mathbf{1 9 6 0}$ to 1969 & 372 & 25 & 6,7 & 15 & 60 & 10 & 40,0 \\
$\mathbf{1 9 7 0}$ to 1979 & 447 & 41 & 9,2 & 24 & 58,5 & 17 & 41,5 \\
$\mathbf{1 9 8 0}$ to 1989 & 494 & 82 & 16,6 & 43 & 52,4 & 39 & 47,6 \\
$\mathbf{1 9 9 0}$ to 1999 & 566 & 132 & 23,3 & 79 & 59,8 & 53 & 40,2 \\
$\mathbf{2 0 0 0}$ to 2006 & 326 & 82 & 25,2 & 49 & 59,8 & 33 & 40,2 \\
$\mathbf{1 9 0 0}$ to 2006 & 3.336 & 421 & 12,6 & 238 & 56,5 & 183 & 43,5 \\
\hline
\end{tabular}

Fuente: Estudio histórico-demográfico (ver Gamella 2019)

Figura 1. Evolución de los matrimonios mixtos en la población gitana/calé de 22 municipios contiguos en Andalucía oriental. Porcentajes de matrimonios mixtos sobre el total de matrimonios gitanos

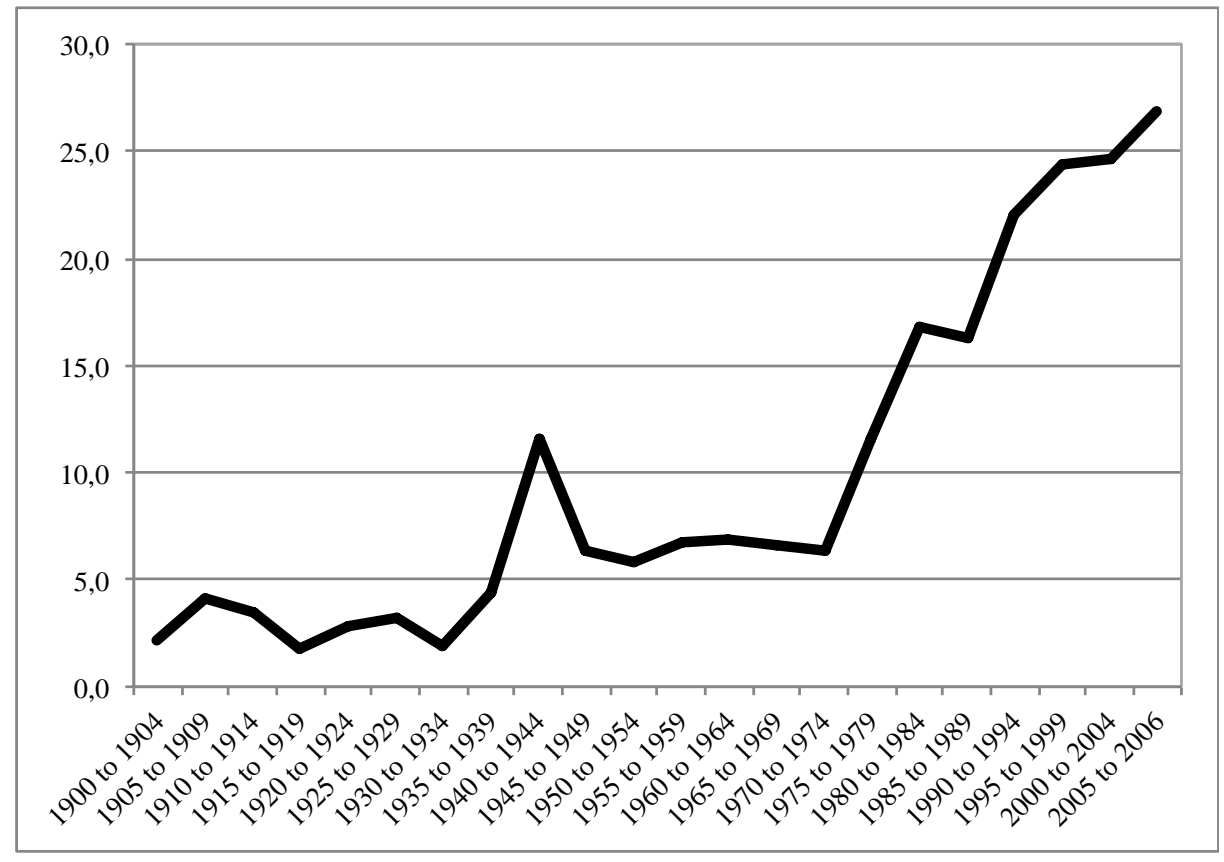

Fuente: Estudio histórico-demográfico (ver Gamella 2019) 


\section{Resultados}

El crecimiento de los matrimonios mixtos ha sido constante desde 1975 y ha alcanzado niveles muy altos desde 1990 (tabla 1 y figura 1). Para todo el siglo estudiado la proporción de matrimonios mixtos fue de 12\%. Pero desde 1990 esa proporción se ha duplicado hasta el $24 \%$. En esta zona observamos cuatro períodos principales en relación al peso de los matrimonios mixtos. Entre 1900 y el final de la Guerra Civil en 1939, la proporción de matrimonios mixtos permaneció baja, en torno al 3\%. En la inmediata posguerra hubo un incremento en los matrimonios mixtos, en parte por los desplazamientos y las separaciones familiares causadas por la guerra. A partir de entonces, durante el resto del Franquismo, entre 1945 y 1975 el nivel de entrecasamientos se mantuvo en el entorno del $7 \%$. En el período democrático empezó a afianzarse un incremento de los matrimonios mixtos en dos períodos sucesivos. En el primero entre 1975 a 1989 la tasa de matrimonios mixtos se duplicó hasta alcanzar un promedio cercano al 15\%. En las décadas posteriores, entre 1990 y 2006 siguieron aumentando hasta representar uno de cada cuatro matrimonios $(24,5 \%)$, reafirmándose entonces grandes variaciones locales.

\section{El decisivo papel de la comunidad local}

Hemos encontrado enormes diferencias entre unos pueblos y otros en la expansión del mestizaje. En algunos pueblos, los matrimonios mixtos han sido raros, mientras en otros se han ido tornando en algo común y cada vez más normal. Así, en nuestra región de estudio, hay pueblos donde las uniones mixtas constituyen cerca de la mitad de todas las uniones celebradas por personas gitanas nacidas en el pueblo, mientras en otros apenas suponen el 5\%. La historia de las familias gitanas y de su integración en la vida local ha sido muy diferente en unos sitios y en otros. En general, donde se ha reducido la segregación residencial, laboral e interactiva, los matrimonios mixtos se han tornado más frecuentes.

Cuatro de los pueblos estudiados, todos con importantes poblaciones gitanas, muestran niveles muy bajos de entrecasamiento. En estos pueblos todavía la segregación residencial es alta, y los gitanos viven en barrios segregados que presentan signos de exclusión y marginalidad y donde los payos no gustan de aventurarse. Generalmente las familias gitanas muestran niveles educativos más bajos y oficios o trabajos más irregulares y precarios. En estos pueblos la minoría gitana sufrió una larga historia de segregación y 
rechazo, aunque desde los años 80, con la llegada de los nuevos ayuntamientos democráticos, los gobiernos autonómicos y la generalización de los servicios públicos, los gitanos han compartido con sus vecinos los espacios y servicios públicos de la educación, la salud, la vivienda, y las rentas y subsidios públicos. Aquí, aunque payos y gitanos van a los mismos colegios y comparten las mismas consultorios médicos y los mismos hospitales y servicios asistenciales, los prejuicios y estereotipos mutuos son más intensos y son raras las amistades estrechas entre payos y gitanos. Con todo y a pesar de los prejuicios antigitanos que prevalecen en la mayoría dominante, también aquí encontramos familias gitanas que son respetadas y valoradas por sus vecinos no-gitanos. Por lo tanto, las generalizaciones no representan bien la variedad de relaciones interculturales, ni las experiencias de confianza y solidaridad que también existen entre familias que han vivido juntas durante generaciones.

Por otro lado, en la misma comarca hay otros cuatro pueblos que presentan proporciones altas de matrimonios mixtos. En esos pueblos muchas familias gitanas se incorporaron hace décadas al centro residencial del pueblo y tienen viviendas que se diferencian poco de las de sus vecinos. El nivel educativo y económico de algunos jóvenes de esas familias es también más elevado, y en general se distinguen mucho menos en sus condiciones de vida, sus recursos y sus estilos de vida de sus vecinos mayoritarios.

En algunos de estos pueblos la integración de una proporción importante de las familias comenzó ya en los años 40, cuando fueron incluidos en procesos de reparto de tierras fruto de una compra de las tierras del municipio a propietarios absentistas. En otros casos la integración sociocultural se ha ido acentuando en el período democrático, particularmente desde los años 80 , pero apoyándose a menudo en cambios que ya se percibían anteriormente.

A su vez los hijos de los matrimonios mixtos están optando por nuevas formas de identificación y afiliación, reiterando uniones mixtas y reestructurando las barreras étnicas. La expresión más común en estos contextos locales es: "aquí viven gitanos, pero están muy integraos" insistiendo que, a menudo, la gente olvida incluso cualquier diferencia étnica. En el resto de pueblos se dan situaciones intermedias y hay redes familiares gitanas que se colocan más o menos cerca de esos extremos. En algunas familias, incluso de comunidades enteras, asistimos a procesos de asimilación prácticamente completa en la población mayoritaria. 


\section{Mestizaje y género}

En la región estudiada, es mayor la proporción de mujeres gitanas que se casan con varones no-gitanos que al contrario. Esta disparidad ha ido creciendo a lo largo del siglo XX y se sitúa en las últimas décadas en proporciones de 60/40\% a favor de las mujeres (ver tabla 1). Este patrón de exogamia étnica contradice las normas explícitas de la cultura gitana tal como se presenta en algunos discursos hegemónicos. Tradicionalmente, el que una mujer gitana se uniera a un payo era algo reprobable, porque se suponía que eso implicaba la pérdida de esa mujer y de sus hijos para su comunidad de origen (San Román 1976: 143,147; Lagunas 2005: 252-53). Como en tantos otros aspectos de la realidad sociocultural de esta minoría, las asunciones más acendradas no corresponden con las conductas que se observan cuando se tienen datos poblacionales. Así, ya en el único censo completo de población gitana disponible, el de 1783-85 eran más las mujeres que los varones gitanos que aparecían casadas con "castellanos" o "españoles". De otro lado, no siempre los hijos de un matrimonio mixto han tomado la identidad étnica del padre. Hay numerosos e incluso notables casos en que esto no ha sido así (Gómez Alfaro 1999: 39; Pym 2007: 165). Es cierto que muchas familias gitanas rechazaban a las mujeres que se casaban con no-gitanos. Tampoco las familias payas aceptaban con facilidad tales uniones. Esto, precisamente, otorga más valor a ese dato de un mayor número de mujeres gitanas optando por esta opción y nos interroga sobre la capacidad transformadora y transgresora de las mujeres gitanas que ha sido frecuentemente ignorada.

Así, los discursos dominantes tanto payos como gitanos retratan de forma estereotípica a los varones gitanos como más rígidos en sus roles e ideologías de género, y describen una sociedad patriarcal y"machista"donde las mujeres están sometidas a sus padres y hermanos cuando niñas o mozuelas, y a sus maridos y suegros cuando se casan (San Román 1976; 1997). Sin embargo, el poder y la influencia de muchas mujeres gitanas en las decisiones de sus familias ha sido poco documentada o valorada. En muchas parejas, las mujeres gitanas tienen un papel central en la marcha de sus hogares, en la educación de los hijos y en los procesos de inversión y decisión económica e incluso política. Es cierto que tratarán de no mostrar públicamente esa influencia sobre sus maridos; sin embargo, cuando se estudian las historias de muchas parejas gitanas y se les escucha en su intimidad, a menudo la agencia de las mujeres gitanas se manifiesta de forma clara, decisiva y transformadora. Eso es particularmente evidente cuando se trata de mujeres mayores y experimentadas, que suelen ser muy respetadas en su familia. Ha ocurrido, además, que muchas mujeres gitanas nacidas en las últimas décadas, han tenido oportunidad de 
ejercitar esa agencia y capacidad siendo más jóvenes. Y es que se está produciendo una mutación en las relaciones de género en la minoría gitana y se aprecian marcados deseos de igualdad en muchas de sus mujeres.

Conviene recordar que las vidas de las mujeres gitanas han sido transformadas en las últimas décadas por cambios interseccionales y estratégicos. Por citar dos de los más importantes, primero es preciso considerar el impacto de la incorporación de las niñas y jóvenes gitanas en el sistema público de educación, lo que ha llevado a la casi total erradicación del analfabetismo femenino en las nuevas generaciones y a la consolidación de un importante sector de mujeres gitanas con estudios medios y superiores.

El segundo cambio estratégico deriva del creciente control por las mujeres calés de su propia reproducción, siguiendo modelos culturales autóctonos, por ejemplo, respecto al calendario de la fecundidad. Esto se ha visto facilitado por al disponibilidad de servicios de planificación familiar resultando en un uso generalizado de métodos anticonceptivos por las mujeres gitanas casadas. Esto ha permitido realizar una transición a niveles más bajos de fecundidad, entre dos y tres hijos por mujer de promedio. Con esto se ha reducido notablemente el período vital que las mujeres gitanas suelen dedicar a los embarazos y la crianza de sus hijos y ha hecho aumentar sus deseos y expectativas de mejorar su formación y tener empleos remunerados.

Además, la ideología de la igualdad y equidad de género, tan extendidas hoy en España, han entrado también en el universo familiar gitano. Muchas mujeres gitanas están buscando relaciones más igualitarias en sus relaciones de pareja y en su vida entera. Además, siguen patrones de homogamia y buscan compañeros que coincidan con ellas en términos de educación, estatus socioeconómico y expectativas vitales. Sabemos que las mujeres gitanas, seguramente más acostumbradas al sacrificio y a la renuncia, están obteniendo resultados educativos superiores cuando encuentran un mínimo de igualdad y apoyo familiar. En muchos de estos casos vemos que a estas mujeres les resulta difícil encontrar parejas gitanas adecuadas a sus perfiles de edad, educación y expectativas; con frecuencia esto les lleva a formar uniones mixtas. 


\section{Conclusión}

Los matrimonios mixtos están aumentando rápidamente en muchas comunidades gitanas/calé de España. En el área andaluza estudiada estos matrimonios han pasado de ser uno de cada 30 matrimonios gitanos en el primer tercio del siglo XX a ser uno de cada cuatro en su final. Esa proporción se dobla en algunos pueblos y zonas urbanas, particularmente allí donde las familias gitanas están logrando mayores niveles de integración estructural y convergencia cultural con sus vecinos. A su vez, los matrimonios mixtos están creando nuevas formas de interacción entre personas, familias e identidades. En este artículo hemos señalado dos aspectos del proceso de ruptura de la endogamia secular: la influencia del entorno local y las diferencias de género en el nuevo mestizaje. Ambos aspectos apuntan a las profundas transformaciones y heterogeneidades que se observan en la vida social de una minoría a menudo representada e imaginada como invariable y monolítica.

El aumento de los niveles educativos, laborales y socioeconómicos de muchas familias gitanas ha aumentado las posibilidades de las uniones mixtas. Los cambios en las mentalidades y las conciencias ha llevado a una mayor convergencia de muchas familias en su experiencia diaria y la representación cultural. No obstante, también han surgido nuevos elementos de diferenciación cultural e incluso de segregación social, como la que observamos en esos guetos verticales que han proliferado en tantas ciudades españolas, ahora por la intervención oficial.

Asistimos a una transformación histórica que está generando nuevas formas de experimentar y representar la identidad y la condición personal de muchas personas gitanas. Los hijos y nietos de estas uniones tienden a desarrollar diferentes estrategias de identificación y filiación étnica. Nos constan tres trayectorias básicas con muchas variaciones individuales. En unas familias ha predominado la asimilación a la minoría y en otras, a la mayoría dominante. No obstante, observamos también una tercera opción más compleja y contingente en la que los hijos y nietos de parejas mixtas desarrollan identidades híbridas y biculturales que buscan aunar herencias de ambas familias y tradiciones en un mestizaje enriquecedor. En cualquier caso, las opciones que acaben predominando en los herederos de estas tradiciones a menudo artificialmente presentadas como incompatibles es una importante pregunta que responderá el futuro. 


\section{Bibliografia}

Alba, R., y Duyvendak, J. W. (2019), "What about the mainstream? Assimilation in super-diverse times", Ethnic y racial studies, 42(1), 105-124.

Alba, R. D., y Nee, V. (2003), Remaking the American Mainstream: Assimilation y Contemporary Immigration, Cambridge Mass., Harvard University Press.

Cantón, M. (2004), Gitanos pentecostales: una mirada antropológica a la Iglesia Filadelfia en Andalucía, Sevilla, Signatura Ediciones.

Gamella, J. F. (1996) La población gitana en Andalucía. Un estudio exploratorio de sus condiciones de vida, Sevilla, Junta de Andalucía.

Gamella, J. F. (2000), Mujeres gitanas Matrimonio y género en la cultura gitana de Andalucía, Sevilla, Junta de Andalucía.

Gamella, J. F. (2011), Historias de éxito Modelos para reducir el abandono escolar de la adolescencia gitana, Madrid, Ministerio de Educación.

Gamella, J. F. y Martín, Elisa (2017), "The decline of infant y child mortality among Spanish Gitanos or Calé (1871-2005), A microdemographic study in Andalusia”. Demographic Research, 36, 945-988.

Gamella, J. F. (2019). "Consanguineous marriages among Andalusian Gitanos/Calé: a genealogical analysis (1925-2006)", Journal of Biosocial Science, 1-23, doi:10.1017/S0021932019000804.

Gay Blasco, P. (1999). Gypsies in Madrid: Sex. Gender and the Performance of Identity, Oxford, Berg.

Gómez A. A. (1999). “Tipologías Matrimonios mixtos y mestizajes Gitanos en los censos históricos andaluces", Demófilo 30, 30-52.

Lagunas, D. (2005). Los tres cromosomas: modernidad identidad y parentesco entre los Gitanos catalanes, Granada, Editorial Comares.

Leblon B. (1985). Les Gitans d'Espagne le prix de la différence. Paris: Presses Universitaires de France.

Livingston, G. \& Brown, A. (2017), Intermarriage in the US 50 years after Loving v. Virginia. Whasington DC, Pew Research Center.

Lucassen, L. \& Laarman, C. (2009), "Immigration, intermarriage y the changing face of Europe in the post war period". The History of the Family, 14(1), 52-68.

Martín, E., \& Gamella, J. F. (2005), "Marriage practices y ethnic differentiation: the case of Spanish Gypsies (1870-2000)". History of the Family 10(1), 45-63.

Osanami T., S., Irastorza, N., \& Song, M.. (2016), “Toward building a conceptual framework on intermarriage", Ethnicities, 16(4), 497-520. 
Portes, A., \& Zhou, M. (1993). "The new second generation: Segmented assimilation and its variants", The annals of the American academy of political and social science, 530(1), 74-96.

Pym, R. J. (2007), The Gypsies of Early Modern Spain 1425-1783, New York, Palgrave Macmillan.

Rumbaut, R. G. (1997). “Assimilation y its discontents: Between rhetoric y reality". International migration review, 31(4), 923-960.

Rodríguez-García, D. (2006). "Mixed marriages and transnational families in the intercultural context: A case study of African-Spanish couples in Catalonia" Journal of ethnic and Migration Studies, 32 ( 3), 403-433.

San Roman, T. (1997). La diferencia inquietante: viejas y nuevas estrategias culturales de los Gitanos. Madrid: Siglo XXI.

San Román, T. (1976). Vecinos gitanos, Madrid, Akal.

Scheffler, H. W. (2018). Filiation y Affiliation. Londres, Routledge. 


\title{
Capítulo 12.
}

\section{Principales resultados del estudio: La experiencia gitana de la vejez. Estudio psicoantropológico de las diferencias culturales en los procesos de envejecimiento y sus consecuencias psicosociales.}

\author{
ÁNGEl HEREDIA AMADOR ${ }^{1}$ \\ Doutorado em Psicologia, Universidade de Granada \\ kalito_1@msn.com
}

\section{JUAN FRANCISCO GAMELLA MORA}

Antropólogo, Professor catedrático em Antropología, professor titular na Universidade de Granada gamella@ugr.es

\section{Jose María Salinas MartíneZ DE LECEA \\ Psicólogo, Professor titular na Universidade de Granada \\ salinas@ugr.es}

Resumo: Apesar das diferentes políticas e iniciativas de intervenção social implementadas nas últimas décadas na Espanha, buscando o bem-estar geral e a equidade entre todas as pessoas, a minoria etnocultural dos ciganos continua a suportar diferentes deficiências e desigualdades em muitas áreas vitais básicos que são fortalecidos, especialmente durante a velhice.

Em 2018, os principais resultados, encontrados no primeiro estudo comparativo internacional sobre a incidência do envelhecimento e suas consequências psicossociais, foram apresentados em uma amostra de ciganos e não ciganos de uma região de Granada. Modelos de pesquisa descritivos e comparativos com projeto caso-controle foram combinados. A amostra foi de 181 pessoas, 95 ciganos auto-designados e 86 não ciganos com mais de 55 anos; o último grupo serviu como um grupo de controle. A análise dos dados epidemiológicos foi realizada com o programa Epi Info, software SPSS e análise de variância e correlações entre os escores das diferentes variáveis. Além disso, foi incluído

\footnotetext{
${ }^{1}$ Ángel Heredia Amador es Doctor en psicología por la Universidad de Granada, Espanha, experto en nutrición y gerontología, Ha fundado con otros profesionales gitanos y gitanas una ONG de intervención psicosocial y educativa que trabaja sobre todo en Andalucía.
} 
material qualitativo das entrevistas biográficas, onde foi estudado o conteúdo relacionado ao tema do estudo.

De acordo com as evidências encontradas, concluímos que a velhice nos ciganos ocorre prematuramente e tem pior prognóstico do ponto de vista psicopatológico e social, em comparação com os não ciganos com características semelhantes na população em geral, com consequências tão prejudiciais quanto menor expectativa de vida entre 5 a 10 anos mais baixa, pior qualidade de vida e maior índice de problemas psicológicos.

Palavras- chave: Ciganos; envelhecimento; Espanha

Abstract: Despite the different policies and initiatives of social intervention implemented in recent decades in Spain, seeking general well-being and equity among all people, the ethnocultural minority of gypsies continues to endure different deficiencies and inequalities in many vital areas basic that are strengthened, especially during their old age.

In 2018, the main results, found in the first international comparative study on the incidence of aging and its psychosocial consequences, were presented in a sample of gypsies and non-gypsies from a region of Granada. Descriptive and comparative research models with case-control design were combined. The sample was 181 people, 95 selfassigned gypsy individuals and 86 non-gypsy individuals older than 55 years; the last group served as a control group. Epidemiological data analysis was performed using the Epi Info, SPSS software and analysis of variance and correlations between the scores of the different variables. In addition, qualitative material from biographical interviews was included, where the content related to the study topic was studied.

According to the indications found, we conclude that old age in gypsies occurs prematurely and with a worse prognosis from the psycho-anthropological and social point of view, compared to non-gypsies with similar characteristics in the general population, with consequences as harmful as lower life expectancy of between 5-10 years lower, worse quality of life and a higher index of psychological problems.

Keywords: Gypsies; aging; Spain 


\section{Introducción}

Numerosos estudios han analizado recientemente el envejecimiento en diferentes poblaciones de todo el mundo pero, que sepamos, este tema no ha recibido atención en lo que concierne a la minoría gitana o calé en España. Mientras que en España la esperanza de vida y el número de personas que envejecen satisfactoriamente no deja de aumentar, la representatividad de gitanos en estos índices gerontológicos es significativamente inferior $\mathrm{y}$, por tanto, el porcentaje de gitanos ancianos es especialmente bajo.

Los gitanos españoles, como colectivo culturalmente diferenciado han estado sometidos a intensos y seculares procesos de exclusión y discriminación, que han resultado en una situación general de bajo nivel socioeconómico, alto nivel de analfabetismo, precariedad laboral, altas tasas de morbilidad y consecuentemente menor esperanza de vida, entre otros perniciosos efectos.

El objetivo de este trabajo es explorar diferentes dimensiones que forman parte de la vejez en ancianos pertenecientes a la minoría étnica de los gitanos, esperando poder determinar algunos de los factores que pudieran intervenir en los supuestos anteriormente señalados. Pondremos especial atención en la situación socioeconómica, salud, estilo de vida, actitudes ante la vejez o exclusión/discriminación, entre otras, considerando con especial atención la situación de la mujer gitana en dicho proceso de la vejez.

Este estudio, se ha llevado a cabo en la Ciudad y la Comarca de Guadix a la que se adscribe población predominantemente rural, aunque también incluye población urbana. El modelo de trabajo es descriptivo-comparativo articulando metodología cuantitativa como cualitativa. Hemos trabajado con una muestra amplia de gitanos y gitanas ancianas, consiguiendo una muestra intencional y variada que hemos emparejado mediante técnicas de caso control, con una muestra equivalente de ancianos no gitanos.

\section{Métodos y técnicas}

\section{Objetivo general}

Explorar las principales diferencias entre ancianos pertenecientes a la minoría étnica de los gitanos y ancianos no gitanos de similar edad, sexo y nivel socioeconómico, en factores relacionados con salud, seguridad y participación. 


\section{Hipótesis principal}

La principal hipótesis que se postula en este trabajo es: el proceso de envejecimiento en personas pertenecientes a la minoría étnica de los gitanos es cuantitativa y cualitativamente diferente, en comparación con la población anciana perteneciente a la población mayoritaria.

\section{Metodología}

La metodología que vertebrará este estudio exploratorio es: descriptiva-comparativa estructurando la batería de técnicas y métodos que permitirán un análisis cualitativo y cuantitativo de la cuestión. Se empleará una combinación de métodos etnográficos y descriptivos, donde se han seleccionado técnicas de recogida y análisis de datos, debidamente validadas en cada uno de los marcos metodológicos de referencia.

\section{Diseño}

El diseño de la investigación es un estudio exploratorio caso-control con muestreo intencional por cuotas.

\section{Muestra}

Para la realización del presente trabajo se han utilizado dos muestras, una perteneciente al grupo minoritario "gitanos" y otra perteneciente al grupo mayoritario "no gitanos". Para asegurar la equivalencia de ambas muestras con respecto al fenómeno estudiado, el envejecimiento, la selección se hizo mediante el método de muestreo opinático o intencional por cuotas de grupos de edad, grupo étnico y sexo-género, de forma que ambas poblaciones estuviesen igualadas en esas variables.

Se entrevistó a un total de 181 personas, un grupo de 95 gitanos y un grupo control, compuesto por 86 no gitanos mayores de 55 años residentes en Guadix y su comarca. Tras la estratificación los grupos resultantes quedaron como aparecen en la siguiente tabla: 
Tabla 1. Distribución de la muestra por grupos de edad, sexo-género y etnia

\begin{tabular}{|c|l|l|l|l|c|}
\hline Grupos de edad & \multicolumn{2}{|c|}{ Hombres } & \multicolumn{2}{c|}{ Mujeres } & NTotal \\
\hline 55 a 65 años & Gitanos & 21 & Gitanas & 21 & 42 \\
\cline { 2 - 6 } N=82 & No-gitanos & 20 & No-gitanas & 20 & 40 \\
\hline 66 a 75 años & Gitanos & 11 & Gitanas & 16 & 27 \\
\cline { 2 - 6 } N=49 & No-gitanos & 11 & No-gitanas & 11 & 22 \\
\hline 76 años y más & Gitanos & 13 & Gitanas & 13 & 26 \\
\cline { 2 - 6 } N=50 & No-gitanos & 13 & No-gitanas & 11 & 24 \\
\hline Total & & 89 & & 92 & 181 \\
\hline
\end{tabular}

\section{Instrumentos}

\section{Cuestionario principal}

Se ha confeccionado el cuestionario principal con 54 ítems, de los que 46 están validados en otras encuestas de salud realizadas con población general a nivel español y europeo. (SAGE, 2014; ENSE, 2012; ENSG, 2006; SHARE, 2005). También se incluyen los siguientes minicuestionarios.

- Cuestionario Yesavage abreviado (GDS), para el despistaje de la depresión en mayores de 65 .

- Cuestionario Índice de Katz o índice de independencia en las actividades básicas de la vida diaria, que evalúa dependencia/independencia funcional.

- Discriminación percibida. Cuestionario "The Everyday Discrimination Scale" (EDS).

- Entrevista biográfica semiestructurada.

- Escala de actitudes hacia la vejez (EAHV).

\section{Análisis}

El tipo de análisis es descriptivo/comparativo, donde los datos de los cuestionarios de ambos grupos se han comparado y se han confeccionado modelos de regresión logística, donde se han valorado variables indicadoras del estado de la vejez como variables dependientes (VD), en función de variables independientes (VI) como: la edad, la percepción 
del estado de salud, nivel educativo, la alimentación, el estilo de vida, la actitud ante el propio envejecimiento o el sexo/género. En estos modelos, se asume una relación logística entre la VD y una combinación lineal de las VI.

Para las entrevistas en profundidad, se ha hecho análisis de contenido, facilitando la descripción e interpretación sistemática de los componentes semánticos y formales del mensaje de los entrevistados, para la formulación de inferencias válidas acerca de los datos reunidos y el objeto de estudio.

\section{Resultados principales}

\section{Bloque $i$}

1. Situación socioeconómica

- Casi 7 veces más analfabetos en gitanos (G48,4\% vs NG 7\%) sobre todo gitanas.

- El 97\% gitanos solamente disponen pensiones no contributivas como fuente de ingresos.

- En gitanos encontramos un $70 \%$ de ingresos inferior.

- Todos los gitanos participantes están por debajo del umbral de pobreza.

○ $\mathrm{N}^{\circ}$ de hijos: un $55 \%$ más en gitanos (G4,8 vs NG3,1).

2. Salud

○ Hipertensión: $50 \%$ más en gitanos $(\mathrm{H}=68,9 \%$ vs $\mathrm{M}=64 \%)$.

○ Colesterol Alto: casi 2 veces más en gitanos ( $\mathrm{H}=55,5 \%$ vs $\mathrm{M}=38 \%)$.

○ Mala circulación: más del $75 \%$ más en gitanos $(\mathrm{H}=40 \%$ vs $\mathrm{M}=54 \%)$.

- Enfermedades del corazón: casi 2 veces más en gitanos (H=20\% vs $\mathrm{M}=22 \%$ )

○ Diabetes: similar, gitanos 5\% superior. $(\mathrm{H}=26,7 \%$ vs $\mathrm{M}=44 \%)$.

○ Asma: casi 3,5 veces en gitanos ( $\mathrm{H}=24,4 \%$ vs $\mathrm{M}=16 \%)$.

○ Úlcera gástrica: muestra muy reducida. 6 veces más en gitanos

○ Artrosis/problemas de huesos: 50\% más en gitanos. $(\mathrm{H}=35,5 \%$ vs $\mathrm{M}=78 \%$ )

○ Medicamentos: 20\% menos de medicamentos en gitanos. 
3. Alimentación

Consumo semanal

- Los gitanos consumen menos fruta, pescado, verduras y hortalizas.

- Los gitanos consumen más carne, huevos, pasta, patatas, cereales, legumbres, fiambres, embutidos, dulces.

- Casi 2 veces más gitanos que no gitanos comen más de lo que deben. $(\mathrm{H}=37,8 \%$ vs $\mathrm{M}=42 \%)$

- Más del $50 \%$ de gitanos come alimentos que no debe por su estado de salud. ( $\mathrm{H}=44,4 \%$ vs $\mathrm{M}=48 \%)$

4. Dependencia

- Tienen reconocido grado de dependencia 4 veces más gitanos en comparación con los no gitanos. 3/4 partes de los casos son gitanas.

5. Estilo de vida

- 2 veces más casos de gitanos tienen conductas sedentarias en el hogar.

○ 3 veces más gitanos que no gitanos NO hacen ejercicio físico programado.

6. Apoyo de las redes sociales

○ Los gitanos tienen más visitas de su entorno familiar (G95,8\% vs NG81,4\%.

○ 2 veces más gitanos ( $\mathrm{H}=35,5 \%$ vs $\mathrm{M}=60 \%)$, necesitan ayuda para desenvolverse en la vida cotidiana.

○ Los gitanos/as reciben más ayuda de familiares (G58,9\% vs NG17,4\%).

- Los gitanos se sienten más valorados por su familia (G96,8\% vs $84,9 \%$.

7. Discriminación

- El 99\% de los gitanos perciben algún tipo de discriminación. 


\section{Bloque ii}

1. Depresión

Gráfico 1. Efectos sobre la etnia y el sexo sobre las puntuaciones del cuestionario

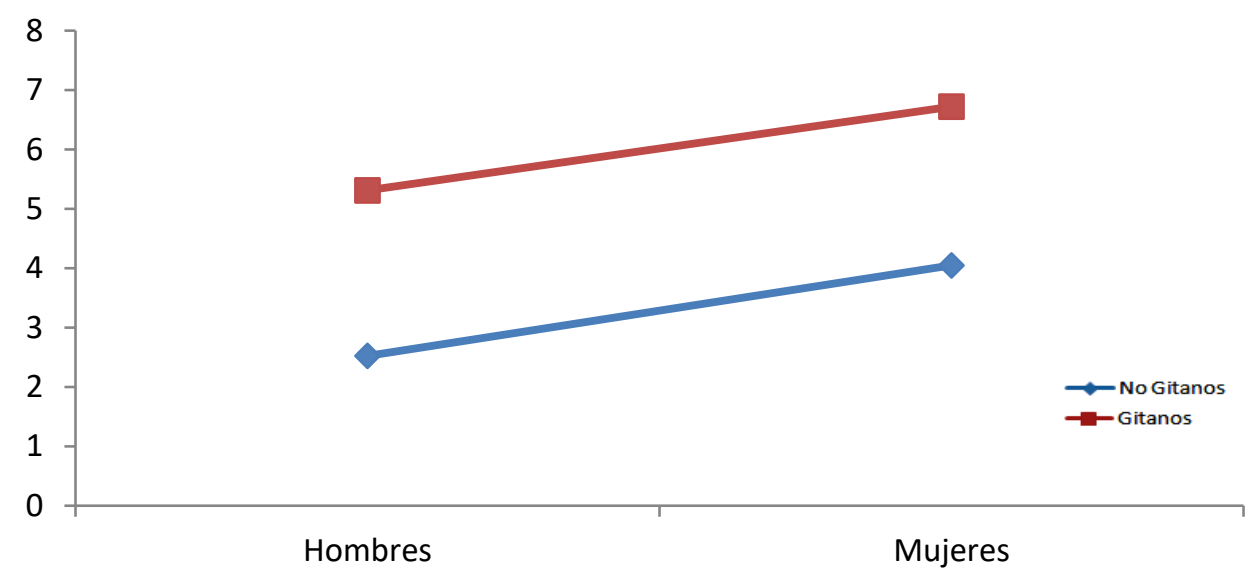

2. Escala de actitudes hacia la vejez

Tabla 1. Porcentajes de respuestas afirmativas de gitanos y no gitanos, a los ítems de la escala de actitutes ante el envejecimiento, calculados según el propio grupo étnico.

\begin{tabular}{|l|l|l|}
\hline ACTITUDES ANTE EL ENVEJECIMIENTO & Gitanos & No gitanos \\
\hline La vejez es una etapa próxima a la muerte & 84,2 & 63,9 \\
\hline Las personas mayores tienen problemas para aprender algo nuevo & 70,5 & 53,5 \\
\hline Las personas mayores están muy interesadas en el futuro & 58,9 & 72,1 \\
\hline A los ancianos sólo les queda descansar y no trabajar más & 72,6 & 55,8 \\
\hline A medida que nos hacemos mayores perdemos el interés por las cosas & 84,2 & 63,9 \\
\hline A medida que envejezco las cosas me parecen mejor de lo que esperaba & 14,7 & 47,7 \\
\hline Me siento menos útil a medida que envejezco & 81 & 60,5 \\
\hline NTotal & 95 & 86 \\
\hline
\end{tabular}




\section{Conclusiones}

Ofreciendo una visión integradora en relación con los datos obtenidos de las diferentes metodologías utilizadas en el presente estudio, concluimos que la situación socioeconómica de los gitanos y gitanas participantes es significativamente inferior, en comparación con personas no gitanas de similares características. Sobre todo, los gitanos más ancianos, tienen un menor nivel formativo con altísimas tasas de analfabetismo absoluto y funcional, facilitado por una situación basal de discriminación y limitación de oportunidades. Desde la niñez, la mayoría de los gitanos participantes, tuvieron que anteponer la subsistencia vital frente a ir a la escuela puesto que no tenían qué comer ni tan siquiera con qué vestirse. Se comprende que, desde muy pequeños, aprendieran oficios desempeñados por sus progenitores, ayudando también en las actividades agrícolas por cuenta ajena o quedándose al cuidando de sus hermanos pequeños. Aunque la escolarización fue mayor en generaciones posteriores, las circunstancias de desventaja social de los gitanos siguen incidiendo negativamente en su vida diaria. El caso de las niñas gitanas es especial. Además de la presión social que sufrían por razones de pertenencia etnocultural, también tenían que afrontar el machismo imperante tanto fuera como dentro del sistema calé. A una niña gitana, generalmente, no se le permitía ir a la escuela puesto que la cultura valoraba que fueran "gitanas de bien", es decir, buenas amas de casa, madres y esposas, entre otros roles asociados. La escuela para esto "no servía”, entendiendo que "allí se echaban a perder las mujeres porque "iban a buscar novios". Si el analfabetismo supone un alto porcentaje en gitanos, en gitanas, es el más elevado de los grupos estudiados.

Teniendo un menor nivel formativo, las oportunidades laborales para los gitanos fueron precarias y muy duras. Las labores agrícolas y oficios varios, no aportaban suficiente a familias muy numerosas, exponiendo a los individuos a formas de semiesclavitud o a la mendicidad, marcando el resto de su vida. Los efectos de una vida laboral que requería alta exigencia física a expensas de numerosas inclemencias meteorológicas junto a la carencia de alimentos básicos, están estrechamente asociados con el padecimiento de enfermedades de manera prematura y altos índices de discapacidad y dependencia. Según los datos encontrados sobre dependencia funcional, concluimos que los gitanos, especialmente las gitanas, suponen un mayor porcentaje de dependencia en sus diferentes grados, en comparación con cualquiera de los grupos estudiados.

En todas las enfermedades propuestas en el cuestionario, se han encontrado mayor porcentaje de gitanos en comparación con los no gitanos. Destacan aquellas relacionadas 
con el aparato circulatorio y los problemas osteoarticulares, estos últimos, sobre todo en gitanas. Además, se manifiestan precozmente la mayoría de enfermedades propuestas, concomitantes con etapas avanzadas del envejecimiento. De hecho, muchos gitanos y gitanas participantes, a edades cercanas a los cincuenta años, padecen enfermedades crónicas como la diabetes tipo dos, artrosis y problemas de huesos, obesidad o problemas bucodentales graves.

Sin embargo, aunque los gitanos padecen más enfermedades a edades prematuras desde el punto de vista gerontológico, consumen casi una cuarta parte menos medicamentos. Paradójicamente, el número de visitas al médico es similar en ambas poblaciones, hay un miedo manifiesto por parte de los gitanos a tomar muchos medicamentos. Frecuentemente, aguantan los síntomas de alarma biológica que el organismo manifiesta ante una enfermedad, hasta que el problema es demasiado grave. Cuando sí toman los medicamentos, en muchos casos, abandonan los tratamientos antes de lo recomendado una vez que remiten los síntomas. Evidentemente, cuando eran jóvenes, la necesidad de trabajar para poder subsistir, se anteponía a las enfermedades que tuvieran y no acudían al médico. Tanto las consultas como las medicinas se tenían que pagar con dinero que no disponían. El vigor de la juventud pudo solventar, al menos momentáneamente, esas vicisitudes. Pero mantener esa misma actitud cuando el cuerpo dice “¡Basta!”, supone un agravio extra que acelera el curso del proceso de envejecer.

En lo referente a los hábitos de vida, los gitanos duermen más durante el día y desempeñan conductas más sedentarias en el hogar, en comparación con los no gitanos participantes. En la misma línea, el porcentaje de gitanos que practican ejercicio físico programado es casi inexistente. El estado biológico deteriorado y las diferentes discapacidades que los gitanos presentan, pudieran ejercer como barreras para la no práctica de ejercicio regularmente. Además, el rol asociado culturalmente con los gitanos ancianos se concibe dentro del hogar. Cuando se tienen que divertir lo hacen en familia. No se suelen ver a gitanos en viajes del IMSERSO o teniendo actividades de ocio y tiempo libre fuera de su hogar. Sin embargo, desde el marco de envejecimiento activo de la OMS, las actividades de ocio y tiempo libre o la actividad física adaptada son condiciones estrechamente relacionadas con una buena salud física y psicológica.

Respecto a la alimentación, los gitanos participantes consumen semanalmente menos fruta, pescado, verduras y hortalizas. Sin embargo, ingieren más carne, huevos, pasta, patatas, cereales, legumbres, fiambres, embutidos y dulces. La proporción de gitanos que comen más de lo que deben y alimentos desaconsejados por su estado de salud, casi dobla 
a la proporción de no gitanos. Podemos concluir que los hábitos de alimentación de los gitanos participantes son menos saludables, en comparación con los ancianos no gitanos.

En el tiempo en que los participantes más longevos fueron niños o adolescentes, artículos como la carne en sus diversas presentaciones, el pan y sus derivados o los dulces, solamente estaban en posesión de personas pudientes. Como en etapas posteriores sí han tenido acceso a esos y otros alimentos, se produce lo que algunos han venido a llamar "síndrome del hambre atrasada", es decir, comen más de lo que deben y alimentos desaconsejados por su estado de salud. Esta actitud, está siendo replicada por los que, teniendo más de 55 años, no superan los 70. Han sobrepasado los límites saludables de una dieta equilibrada al incorporar gran cantidad de calorías procedentes de, sobre todo, carbohidratos de absorción rápida y grasas saturadas. Cuando se ingieren este tipo de alimentos, se depositan en forma de adipocitos, si no se gastan mediante ejercicio físico. Por agregado lógico, el alto porcentaje de gitanos con enfermedades del aparato circulatorio, obesidad o diabetes tipo II, que hemos encontrado en la muestra, está directamente relacionado con los hábitos de alimentación poco saludables y un estilo de vida sedentario. Esta circunstancia agrava aún más la alta morbimortalidad asociada con los factores referidos.

Debido a los altos índices de dependencia en sus distintos grados que, sobre todo los gitanos soportan, necesitan ayuda externa para realizar las actividades de la vida diaria (AVD). Esta ayuda la reciben, principalmente, de hijos o familiares cercanos. Puesto que reciben visitas frecuentes de personas significativas, preferentemente familiares, los gitanos y gitanas se sienten más satisfechos con su vida y además se sienten más valorados por su familia en mayor proporción que los no gitanos. Este dato, tiene apoyo, fundamentalmente, desde un punto de vista cultural. A los ancianos gitanos se les valora y respeta en gran manera, por ser el principal repositorio de la cultura y tradiciones. No hemos encontrado ningún caso de ancianos gitanos solos o en residencias de la tercera edad. Se les cuida, generalmente, en sus hogares por sus hijos o familiares cercanos, quienes se turnan para estar junto a ellos. En cambio, hemos contabilizado visualmente hasta una cuarta parte de personas no gitanas solas y otro porcentaje muy alto sin determinar, en residencias.

Prácticamente el total de la muestra de gitanos, siguen percibiendo conductas racistas hacia ellos. Esto nos hace pensar que los procesos de discriminación y racismo no han desaparecido, ni tan siquiera, ha disminuido su incidencia. Lo que sí planteamos es que se ha producido una adaptación de dichos procesos. Actualmente, las actitudes racistas frontales y directas, suponen un porcentaje relativamente pequeño. En cambio, los efectos 
del racismo sutil y subyacente se dejan sentir en la vida cotidiana diariamente. En algunas ocasiones, cuando varios candidatos con la misma formación y experiencia se presentan al mismo puesto de trabajo, se excluye con más frecuencia a las personas gitanas que al resto, por apellidos o por apariencia, entre otros muchos motivos banales. Los estereotipos y prejuicios, se han instalado en lo más profundo de las estructuras sociales y es tremendamente difícil poder erradicarlo. Diríamos, que las crisis económicas y sociales, junto a los flujos migratorios que, por desgracia, se están cobrando tantas vidas, exacerban el sentimiento supremacista, reviviendo la persecución directa hacia los gitanos en países como Italia. Como en otras épocas, este factor, extiende sus perniciosos efectos a cualquier faceta de la vida de los gitanos, condicionando indefectivamente su vejez en sentido negativo.

Según los datos esgrimidos de los cálculos estadísticos realizados con cada uno de los ítems del cuestionario y las entrevistas biográficas, sobre actitudes ante el envejecimiento, concluimos que los gitanos y gitanas tienen unas actitudes más negativas ante el envejecimiento, en comparación con los no gitanos de similares características.

Finalmente, según los distintos análisis estadísticos y entrevistas biográficas, encontramos hasta cuatro veces más casos de depresión en gitanos, sobre todo en gitanas, en comparación con los no gitanos de similares características. Estos mismos análisis señalan como factores elicitantes un bajo nivel de ingresos, poca actividad física, mala salud, incapacidad y dependencia, la edad, el número de hijos, el número de medicamentos que se toman, la percepción negativa de la salud, el grado de dependencia, la actitud pesimista hacia la vejez y el escaso apoyo y valoración familiar. Tenemos así configurado un patrón de depresión exógena o reactiva que aparecería ligado a malas condiciones de salud, estatus económico bajo y falta de actividad y de apoyo familiar, entre otras.

Esta es la imagen real que hemos encontrado en gitanos y gitanas mayores de la zona de estudio, pero la sociedad en general, solo conoce a los gitanos basándose en premisas que descansan sobre el perjurio de los estereotipos o el folclore, y en esto, los medios de comunicación tienen mucha responsabilidad. La complejidad que supone el abordaje del estudio de un proceso como la vejez y los efectos de multitud de factores que podrían estar vinculados en cualquier población, es labor más ardua cuando se contextualiza en personas mayores pertenecientes a minorías étnicas porque, en la mayoría de los casos, arrastran y soportan desventajas en multitud de áreas. Se sugiere manejar con cautela los indicios hallados y la conveniencia de poner en marcha nuevas investigaciones más abarcadoras que puedan corroborar los resultados hallados. 
Entre las limitaciones de la presente investigación, podríamos citar que el ámbito donde se realizó es una zona geográfica mayoritariamente rural. Por otro lado, al tratarse de un estudio transversal descriptivo-comparativo, se restringe la información relacionada con la investigación longitudinal. El escaso tamaño de la muestra también es otro factor que limita el alcance del estudio. 


\section{Bibliografia}

Abellán, A., \& Pujol, R. (2016). Un perfil de las personas mayores en España, 2016. Indicadores estadísticos básicos. Madrid: Informes Envejecimiento en Red, (14), 122 .

Arza, J., \& Carrón, J. (2015). Comunidad gitana: La persistencia de una discriminación histórica. Revista de Ciencias Sociales, 10(2), 275-299.

Bazo, M. T. (2004). Envejecimiento y Familia. Arbor, ciencia y pensamiento. 178(702), 323-344.

ERTF (European Roma and Travellers Forum) (2016). Ficha informativa sobre la situación de los romá/gitanos en España. ERTF, 1-19.

FSG, (2011). Población gitana, Empleo e Inclusión social. Un estudio comparado: Población Gitana Española y del este de Europa. FSG. Serie de cuadernos técnicos. (103), 1-188.

Gamella, J. F. (2004). Exclusión social y diferencia étnica: el caso de los gitanos. Publicado en Jose Félix Tezanos (Ed.) Tendencias de desigualdad y exclusión social (pp.603-647). Madrid: Sistema.

Gamella, J. F. (2011). Historias de éxito. Modelos para reducir el abandono escolar de la adolescencia gitana. Ministerio de Educación.

Heredia-Amador, Á., Calvo-Salguero, A., Salinas, J. M., \& Gamella, J. F. (2018). Differences in the prevalence of depression in older Spanish Romany and non-Romany people and associated factors. Psychogeriatrics, 18(4), 313-320.

Heredia, A. (2011). Aproximación a la situación sociosanitaria de las personas mayores de etnia gitana de la zona de Guadix. Trabajo fin de Máster de Gerontología, Dependencia y Protección de los Mayores.

La Parra, D., et al. (2016). Segunda Encuesta Nacional de Salud a Población Gitana 2014. Ministerio de Sanidad, Servicios Sociales e Igualdad. Espanha

MSSSI (2012). Estrategia Nacional para la Inclusión Social de la Población Gitana en España 2012-2020. MSSSI.

Porras, J. A., \& Sánchez, J. C. (2015). Comunidad gitana: la persistencia de una discriminación histórica. OBETS: Revista de Ciencias Sociales, 10(2), 275-299.

U.E. (2014). Roma Health Report: Health status of the Roma population. Data collection in the Member States of the European Union. European Commission, 1-152. 


\section{BIGANOS EM PORTUGAL, ESPANHA E BRASIL analisando contextos, demandas e processos identitários}

